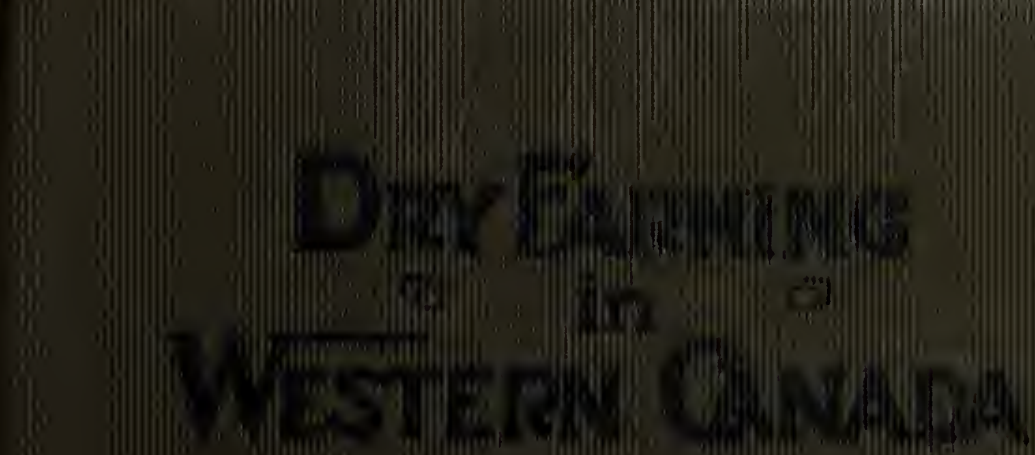



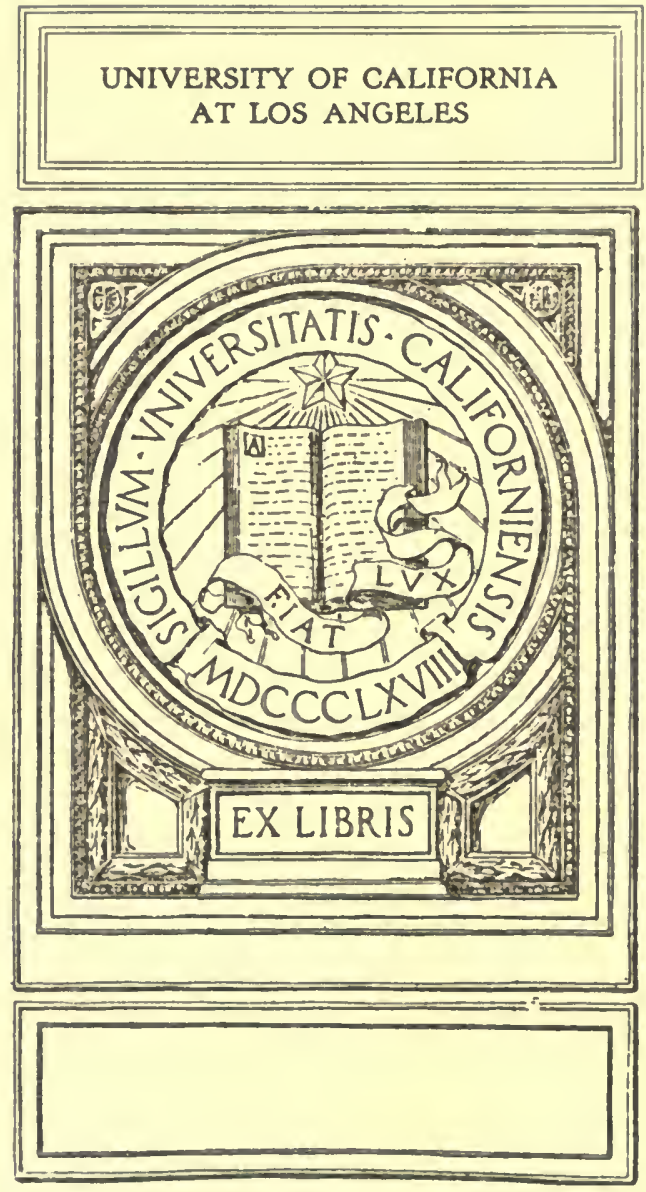
UNIVERSIII Y OI LALIFUKNEA

AT

LOS ANGELES

LIBRARY 
Digitized by the Internet Archive in 2007 with funding from Microsoft Corporation 



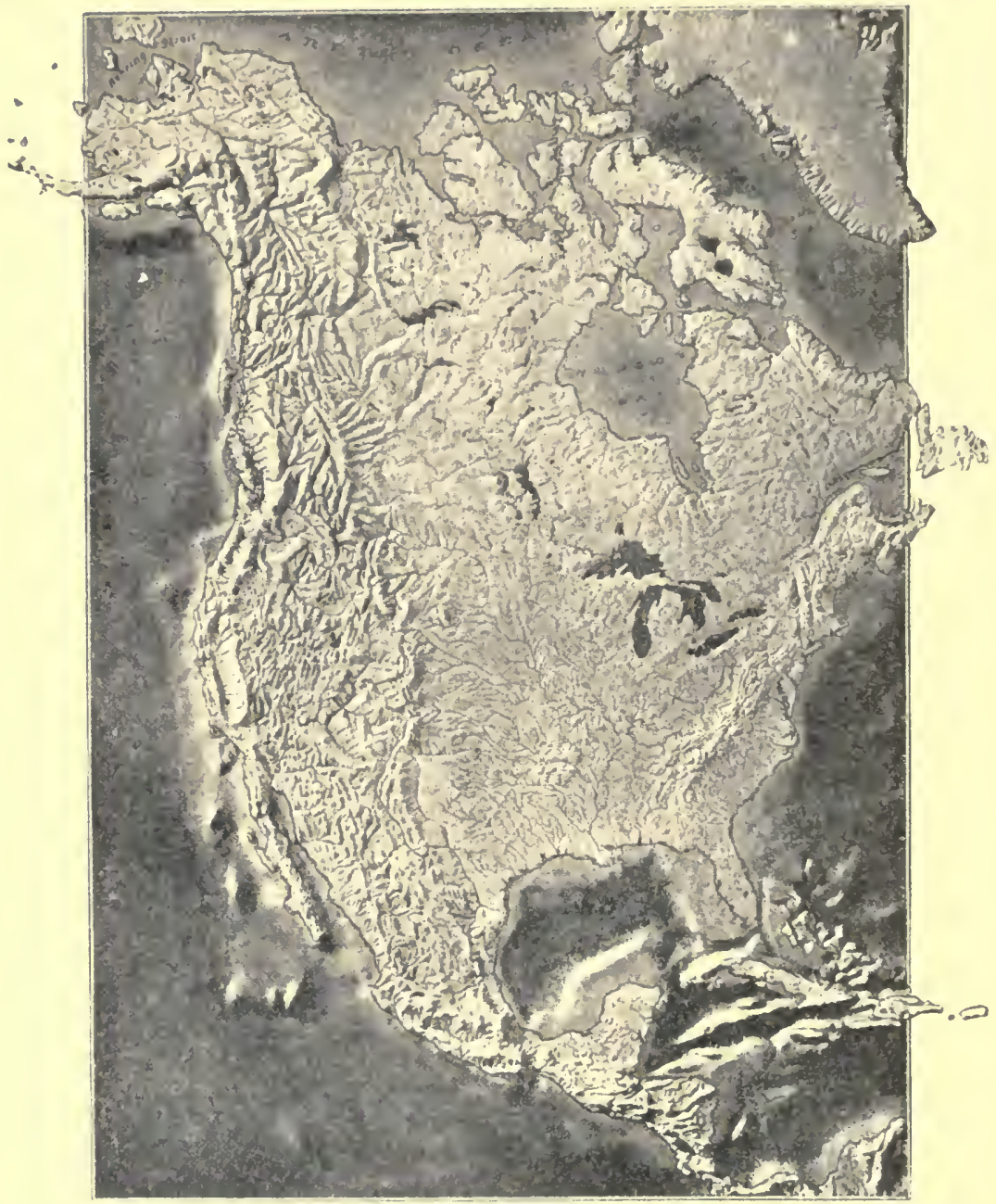

Fig. 1.-Physical Features of North America.-(After Tarr).

The Prairie Provinces lie between the Rocky Mountains on the West and the Hudson's Bay and Great Lakes on the Fast. 


\title{
DRY FARMING
}

IN

WESTERN GANADA

\author{
BY \\ JOHN BRACKEN \\ President, Mlanitoba Agriculutural Colifge \\ FORMERLY \\ Professor of Field Husbandry, \\ UNIVERSity of Saskatchewan
}

'THE GRAIN GROWERS' GUIDE, LIIITED WINNIPEG, CANADA $1 ! 21$

$$
\text { 139201 }
$$




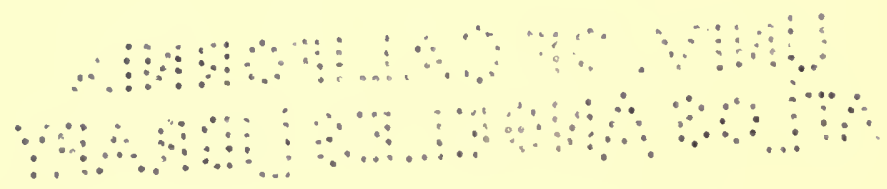




\section{INTRODUC'TION.}

It is only a comparatively few years sinee the vast plains which now eomprise the prairie provinces of Canada were inhabited by Indians and buffalo. Within the past generation this eountry has been settled by over 200,000 farmers. With the exception of those who eame from adjoining distriets immediately south of the international boundary these farmers have had to face conditions that were entirely new to them. The farm practices to which they were aceustomed were altogether different from those required by the soil and climate of the western plains. There has been, therefore, a strong demand for information as to the best kinds of grain and other erops to grow and the best system of eultivation under which to grow them.

Among the experimenters and teachers who have done such splendid work in diseovering and making known the best farm practices for the Canadian west Professor Bracken has taken a place in the front rank. For ten years before his appointment to the position of President of the Manitoba Agrieultural College he was Professor of Field Huslandry at the College of Agrieulture, University of Saskatchewan, Saskatoon. The plan of the experimental farm at that institution, one of the most comprehensive and scientifie on the continent, was devised by him. The results obtained from his own experiments, and the experiments at other stations both in Camadia and the United States, together with the 
vi. INTRODUCTION

experience of successful Great Plains farmers, have been drawn upon to furnish the material for Crop Production in Western Canada, published last year, and Dry Farming in Western Canada. The two books furnish a reliable guide to suceess in the production of field crops muler Great Plains conditions.

The Publishers.

Wimnipeg, Jammary, 1921., 


\section{PREFACE.}

When the manuscript for "Crop Production in Western Canada" was first prepared it included not only the chapters relating to Crops and Cropping Practices whielı appear in it, but also several others dealing with the soil and its management under Western eonditions. When it was discovered that the whole would make a book eontaining nearly 800 pages, it was eonsidered inadvisable to publish it in one volume. Aceordingly the material was divided and that having to do direetly with crops was published in 1919 under the title referred to. The part which treats of the soil and its management appear's in this volume.

The substance of the different ehapters of the book is drawn from lectures and addresses delivered either at the University of Saskatehewan or at Agrieultural MeetIngs at different places in Western Canada or the Western States during the past ten year's. For the contributed portions the author is very greatly indebted to Professor Hansen of the University of Saskatchewan for the chapter on "The Soil"; to W. H. Fairfield, Superintendent of the Experimental Farm, Lethbridge, Alta., for that on "Irrigation" and to ten of the leading ayronomists of the Great Plains Region of Canada and the United States for that on "Lessons from Experience". $\mathrm{He}$ is also indebted to the Canadian and United States Departments of Agrieulture, to many State Experiment Stations, several Dominion Experimental Farms, all of vii. 
viii.

the Western Provincial Departments of Agriculture and the Dominion Meteorological Service for date or illustrations used, or for assistance given in the preparation of the manuscript. To the many private individuals who in one way or another have been of assistance, his thanks are also due.

The many imperfections of the book are known full well to the writer. It is being published not beeause it contains the last word on suecessful farm practice in the west, but rather because it presents under one cover a more or less complete statement of our present knowledge coneerning the methods of producing erops at a profit nuder relatively dry conditions. It is hoped that the book may be found of some value to all farmers and students who are interested in the agrieultural problems of the Prairie Provinces.

J. B. 


\title{
CONTENTS
}

\author{
CHAPTER I.
}

The Development of Dry Farming - - - - -

1. Dry Farming Defined.-2. History of Dry Farming. -3. Where Dry Farming Applies.

\section{CHAPTER II.}

The Climate of Western Canada in its Relation to Crop Production - - - - - - - - - - - - -

4. Climatic Conditions the Chief Causes of Low Yields.5. The Factors of Climate.-6. Importance of Precipitation.-7. Amount of Precipitation per Year.-8. Geograplic Distribution of Precipitation.-9. Monthly Distribution of Precipitation.-10. The Form in which the Precipitation Occurs.-11. Wide Variations from the Average Precipitation.-12. Evaporation.-13. Dry and Wet Years at Saskatoon.-14. Temperature Necessary for Germination and Growth.-15. The Measure of the Heat Supply.-16. The Temperature Zones of Canada. -17. Spring and Fall Frosts in Western Canada.-18. Frost Resistance of Different Crops.-19. The Arerage 'Tenperature of the Growing Period.-20. The 'Total Heat Received During the Period of Growth.-21. W'ind Velocity.-22. 'The Chinook Wind.-23. Humidity of the Wind.-24. Wind Direction.-25. Atmospherie Humidity.-26. I song Hours of Sunlight in the Growing Season. -26a. 'The Effect of I atitude and Altitude on 'Temperature.-2(b). The Effects of Forests on Climate.

\section{CHAPTER III.}

\section{The Soil}

(By Roy Ilansen .I. S. Professor of Soils, University of Saskatchezon, Suskatoon.). 27. The Role of the Soil. (IIistory and Physical Properties).-28. Origin.-29. Soil Classification.-30. Soil Types.-31. Phỹsical Properties of Soils.-32. Dry-Farming and Soil Physics. (Soil fertility or Chemistry).-333. 'The Food of plints. 
-31. The Fissential Filements.-35. The Jissential filoments and Saskatchewan Soils.-36. Arerage Saskatchewan Soil vs. Other Soils.-3i\%. Organic Matter and Soil Fertility-38. Functions of ( reanic Matter.-39. I osses of Organic Matter in the Soil.- 10 . 'Ihe Rothamsted Experiments on Soil-Fertility.-41. Illinois Fxperiment.42. Soil Acielity and liming the 1.and.-43. Crop Rotations and Soil Frertility. (The Soil " Living Mass).-H. Importance of Micro-organisms in the Soil.-45. The Soil a living Mass.-46. Functions of the Bacteria in the Soil. - 17. I'reparation of Available Plant-fond.-18. 'The Nitrogen Crele.-. \$. The Mineral Plant Food Filements.-50. l'arasitism (discase).-51. Nitrogen Fixation by Leguminous Plants. (The Fuctors of Soil Fertility).-52. The Measure of Fertility.

\section{CHAPTER IV.}

\section{The Moisture Problem}

5.3. Storing Moisture in the Soil, -54. (omserving Moisture in the Soil.--55. Keeping Soil Moristure Avalable.56. The Effieient [tilization of Soil Moisture.--57. Soi] Fertility and Soil Moisture.

\section{CHAPTER V.}

Dry Farm Crops and Cropping Practices - - - 58. Drought Resistant Crops,-59. Durmm What.-60. Winter Rye-61. Spring Rye.-6:. Flax.-63. 'TwoRow Barley- -6t. Emmer.-65. Farly Oats.66. Grasses for Hay and Pasture.-67. Alfalfa_-68. Millet.69. Sweet Clover-70. Rape.-71. Corn.-72. Sunflowers.73. Suitable Crop Managenent I'ractices.-7t. The 'Time to Sow.-75. The Amount to Sow.-76. Sow into the Moisture.-77. Non-Shattering Varieties.-78. Short rs. Long Straw.

\section{CHAPTER VI.}

The Principles of Tillage

79. 'Tlue Chief Functions of Tillage- 80 . Objections to Excessive Tillage,--81. Implements of 'Tillatge.-82. 'Tlue Function of the Plow.- 8:3. 'The Disk Plow.-84. Conllers. (Soil Looseners).-85. Cultivators.-86. Disk IHarows.87. Drage or Smenthing IIarrows. (Soil firmers).-85. Purpose of Soit Firmers.-s9. Drills as 'Tillage Mathines. -90. Press Drills. 


\section{CHAPTER VII.}

Breaking the Virgin Prairie - - - - - - - - - -
91. Why We Till Prairie Sod.-92. How Moisture is Stored and Conserved in New Iand.-93. Killing the Native Prairie Plants.-94. Preparation of the Seed Bed. -95. Some Desirable Practices in "Breaking" Prairie Sod,-96. Break Early to Obtain Maximum Yields.-97. Plow all the Land.-98. Turn the Furrow Over Flat.99. Pack or Plank after Breaking.-100. Disc Deep Breaking as soon as Possible after it can be done without Turning up Sods.-101. Cultivate Sufficiently during the Season to Prevent the Growth of Native Plants.-102. To Control Creeping-Rooted Grasses Break Early and Backset.-103. Don't Backset if Sod has not Rotted.104. Land Intended to be Backset Should be Broken Shallow; that not to be Backset, Deeper,-105. Harrow and Pack Backsetting.-106. "Scrub" I and must be Treated Somewhat Differently,-107. Leave Breaking Uncropped until the Following Season,-108. The "Breaking" up of Cultivated Grass I and.

\section{CHAPTER VIII.}

Preparing Park Belt Land for its First Crop - - - 136 109. Iocation and Extent.-110. General Characteristics. -111. Climatic Conditions-112. Character of Vegetation.-113. Methods of Removing "Scrub".-11t. l'lowing Serub Iand.-115. Surface Tillage After Plowing.-116. Cost of "Scrubbing" and "Breaking",-117. The Choice of the First and Subsequent Crops.-118. 'I'he Best System of Farming.

\section{CHAPTER IX.}

The Tillage of Stubble Land - - - - - - - 146 119. The Causes of low Yields.-120. The Control of Soil Moisture.-121. 'The Control of Weeds, Grasses and Shrubs.-122. Seeuring a Good Seed Bed.-123. Importance of "Available" Plant Food.-12\%. The Stubble-a Nuisance, Yet Important.-125. Subsoil Moisture Must be kept Available to I'lant Roots.-126. Some Common Methods of Preparing Stubble land for a Crop.--127. Results of Some Tillage Experinnents at the L'niversity of Saskatchewan.-128. 'The Necessity for Plowing Grassy' Stubble.-129. 'The Desirability of "Working Down" Plowed Land as soon as l'ossible after Plowing.-130. 'The Furrow Slice should be Plaeed Fimly A Arainst the 
Furrow Bottonn--131. Burning Stubble is Permanently Wasteful of Soil Fertility, lut Often Immediately l'rofitable.-132. Surface Cultivation Sometimes Preferahle to l'lowing.-133. Warly Fall Proferable to I ate Fall Cultivation.-13\%. I void Working 'Tight Clay Soils when too Wet.-135. Harrow the Growing Crop only when there is Cause for so Doing.-136. General Observations on Plowing Stubble I and.-137. The Iupportance of "Net" Returins.

\section{CHAPTER X.}

The Summer Fallow -

138. The Function of the Fallow.-139. The Practices of Fallowing.-1 10, Objections to Fallowing.-141. Defence of Fallowing.-142. General Conclusions.

\section{CHAPTER XI.}

Crop Rotations - - - - - - - - - - - - - - Evidence on Rotations.-145. Results of 'Tests at Saskatoon and Brandon.-146. Adrantages of Suitable Crop Rotations.-147. Requirements of Rotations in Western Canada.-148. Difficulties in Establishing Good Rotations in the West.-149. Classes of Crops used in Rotations.-150. Planning a Rotation.-151. Some Well Known Rotations.-152. Rotations now used in the West. -153. Rutation Tests at Brandon-154. 'Ypieal Grim Farming Rotations.-155. A Well lialanced Rotation.-156. The Most Profitable Rotation at Brandon.-157. Rotations withont Corn.-158. A Rotation for a Dairy or Stock Farm,-159. Oloservations on Rotation Tests at Brandon- - 160. Nixed Farming Rotations at I acombe161. Criticisms of these Rotations.-162. A Rotation with many Advantages.-16i3. Rotations witl Sweet Clover:-16. An Adjustable Rotation.-165. Crop Rotations for Special Conditions.-166. 'The Effect of Rotations on Soil Fertility.-16\%. General Conclusions Regarding Rotations.

\section{CHAPTER XII.}

Weeds and Their Control - _ - _ _ - - - - - 211

168. Why Weods are I Tarmful.-169. Some Good points About Wreeds.-170. l'rinciples of Weed Control.-171. Identification of Weods and Weed Seeds.--172. Duration of the Growth of Weeds.-173. Mabits of lioot Growth and 'I'ime of Seeding.-17t. How Weeds Spread.-175. How to Prevent Weeds from Developing Serds.-176. 
How to Kill Perennial Weeds.-17\%. How to Prevent the Introduction of Weeds to the Farm.-178. Neans at Man's Disposal for Controlling Weeds.-179. 'The Control of Annual Weeds.-180. The Control of Winter Annnal and IBiennial Weeds.-181. The Control of Peremial Weeds.-182. l'oisonous or Otherwise Injurious Werets.

CHAPTER XIII.

Irrigation Farming in Western Canada

(By W. H. Fairfield, Superintendent, Experimental Farm, Lethbridge, Alherta)._-183. History of Irrigation in Western Canada.-184. Methods of Irrigation.-18.5. Wild Flooding.-186. The Furrow Systen.-187. The Bedding System.-188. 'I'he "Check" Systen..-189. The 13order System.-190. Sub-Irrigation,-191. Relative Suitability of Varions Crops under Irrigation.-192. Irrigating Timotly and Native Grasses.-193. Alfalfa nnder Irrigation.-194. Grain Crops.-195. Potatoes.196. Other Crops, lnk Inding 'Trees.

\section{CHAPTER XIV.}

\section{The Causes and Control of Low Yields}

197. The Causes of I Low Yields.-198. Poor Seed.-199. 'Too Early or 'Too l ate Seeding.-200. 'Too Much or 'T'oo Jittle Seed per Aere.-201. Unsuitable Varieties.-202. Shattering.-203. Late 13reaking.--204. Seeding on Breaking Done the same Season.--205. Native Jerennial I'lants in Stubble Fields.-206. Plowing When the Soil is 'Too Wet or 'loo Dry-207. l'lowing Under Heary Stubble or Coarse Manure-208. 'T'om I ate Plowing of the Fallow,-209. Weeds.-210. Insects.-211. Plant Diseases.-212. Heary Spring Frosts.-213. I Iail Storms. -21t. Ilot Winds.-215. Dry Seasons.-216. Fall Frosts.

\section{CHAPTER XV.}

\section{The Management of Special Soils}

(1)rifting Soils).-21\%. 'The Damage Caused by Soil Drifting.-218. The Chief Factors Fiaroring Suil Drifting.-219. The Chicf Causes of Soil Drifting.-2:20. The Means Employed to Prevent Exeessive J)anage.-221. Inereasing the IJoisture Content.-2.2.2. Increasing the Organie Matter" (ontent.-2223. Modifying the Structure of the Soil.-224. (irowing l'roterting Crops.-225. Perenuials as Protecting (rops. 220. Winter Rye Lessens 1)rifting.-22\%. Iate Sown ()ats for Soil Protection,-228. Stubble ats a Soil protector.- 
22.9. Corn Stubble lessens Drifting.-2029. Artificial Protection.-230. Miseellaneous Practices and Suggestions.-231. Conclusion. (Alkaline Soils).-232. Why Alkali is Harmful.-2:33.' 'The Reclamation of Alkali Soils.-2:3t. 'The Use of Alkali-Resistant Crops. (Loose Top Soils).-235. Ilow J soose 'T'opl land is J3roken.-236. The Crops Grown.-237. Fallowing I nose 'Top I and -238. 'The Rotation ['sed. ("Burut Ont" Soil).-239. The Management of Jurnt Out Soils.-(Poor Soils).2:39a. The Value of Manure.-2396). The Place of Commercial Fertilizers. (C'old Soils)._-239c. Sonte 1'ractices of Northern Agriculture.

\section{CHAPTER XVI.}

Lessons from Experience -

(Dry Furming in the Greal Plains Region of the L'nited Strites by E. C. Chilcott, Lnited states Department of Agriculture.).-240. Summer 'Tillage-241. Corn or Sorghums vs. 'The Fallow, -242. When Disking May be Substituted for Plowing.-213. 'I'le Use of the lister in the Fall.-24. How and when to Plow.-245. 'The Purpose of Jlowing.-245a. Green Manuring.-246. Destruction of 11 eeds.-24\%. 'The $\Lambda$ pplieation of the Capillary 'Iheory to Dry Farming Practices-2.8. Farm Organization and Croj Rotations. (Dry Farming Practices in Kansus, by L. E. Call, Professor of Agronomy, Agricultural College, Manhattan, Kansas).-2.4. 'The Plaee of Summer 'Tillage.-250. Kansas Dry Farm Crops. -251. Crops that Mature Early-252. The Amoun: of Seed to Sow. (Dry Farming in Febraska, by W. W. Burr, Professor of Ayronomy, Ayricultural Experiment Station, Lincoln, Nebraska).-253. Summer 'Tillage.254. Crop Rotation.-255. Crop) Adaptation.-256. Cultural Practices.-257. 'The Farming Unit.-258. I ive Stock.-259. The P'ossibilities for Dry Farming. (Dry Farming Practices in South Dakota, by Wanley Champlin, formerly Associate Professor of Agronomy, Brookings, S.D.).-260. Summerfallowing.-261. Crop Rotation.-26:2. Drought-Resistant Crolls.-(D)ry Furming Practices in North Dakota, by W. R. Porter, Šuperintendent of Demonstration Furm. for Forth Dakotu).-263. Summer 'I'illage.-26.4. Stubble I and-265. Grass Jind. -266. Rotations._-267. 'The Best Crops.-268. The Rate of Secling.-269. Werels.-270. Soil Drifting.-(J)ry Furming in Montama, by Alfred Atkinson, President Montanu State College of Agriculture, formerly Professor of

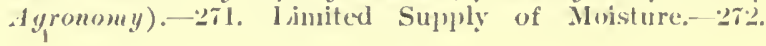


Early Maturing Crops.-273. Iight Seeding.. - (l)ry Farming Practices in the Red River Valley, by T. J. II arrison, Professor of Field IIusbundry, Manitoba Agricultural College, Winnipey).-2rt. 'The Place of the Bare Summerfallow in the Red River Valler.-275. Methods of Fallowing.-2 276 . Subititutes for Summerfallow.-27\%. Preparation of Stubble Land for Crop.-2\%8. Preparation of Grass Land for Crop.-279. IRotations.-280. Inportance of Organic Mattre in Soil.-281. Crops.-252. - Rate of Serding.-283. Dates of Seeding.--284. Weeds, Plant Diseases and Insects._- (Mry Farming in Western Manitoba, by W. C. Mckillican, Superintendent Experimental Farm, Braudon, Man. Summerfallow.)-285. Importance of the Fallow.-286. Methods of Fallowing.287. Dangers of Fallowing.-288. Substitutes for Summerfallow. (Rotations).-289. Rotations now in use. 290. Improvements in Rotations.-290a. Dry Farming Crops.- (Dry Farming Practices in the Park Belt of Albertu, by G. II. IIutton, B.S.A., Superintendent of Agriculture and Animal Industry, C.P.R., Calgary).-291. 'The I'lace of the Summerfallow.-292. Suitable Rotation for the Park 13elt.-293. Corn rs. 'The Fallow.-29.4. The l'rejaration of Stubble Land for the Crop' Following.295. Preparation of Grass I and for the Croj) Following. -296. Organic Matter, 1egumes and Soil--29\%. 13est Dry Farm Crops.-298. Rates of Seeding in Central Alberta.-299. Weeds.-300. Soil Drifting.—301. I'lowing. (The Summerfallow in Southern Alberta, by Janes Murray, B.S.A., Superintendent of Farms, Noble Foundation Limited, Tobleford, Ilberta).-302. Climate.-303, I Fallow Considered Necessary-30\%. Summerfallow to Control Weeds.-305. Plow Summerfallow Farly:-306. Controlling Weods after Plowing.-30\%. Fall 'Treaturent of Fallow:-308. Ho Drill l'referred. :309. '1'wo Inportant l'oints about Fallowing.

\section{CHAPTER XVII.}

The Problem of Crop Production - - - - - - 354

310. 'lhe Problem in a Nutshell.-311. 'The First Part of the I'roblem-that of Growing Crops.-312. Iight and Air lissential but of Little l'ractical Importance-313. Frost Limits the Yield in Northern Clinates. - 31 t. Water in the Soil Determines the Yicld in Dry (Jimates.-.315. Plant Food Materials, the Limiting Factor on Poor Soils. - 3t6. 'The Importance of Gord Seed._-31\%. Some Fundamental Faets.-31s. 'The Vital l'art of the l'roblem-that of 1'rofit. :319. Factors Affecting l'rofit.-:320. 'The cost 
of Weeds.-321. The Cost of Insects.-322. The Loss from Rust. -323. The Amount Hail 'Takes from the Profits.-32.4. The Moral.-325. The Cost of Production and the Selling Price.-326. The State's 'Third of the Problem-that of a Permanent Agriculture-327. Factors that $A$ ffect Permanence.-328. 'The Means at Man's Disposal for Controlling or Influencing the Factors of Growth, Profit and Permanence.-329. 'The Choice of Suitable Cropss.-330. Suitable Cropl Management Pracetices.-331. The Improvement of Crops.-3332. Irrigation and Drainage.-333. 'Tillage-334. Crop Rotations. 335. Crop Rotations and I ive Stock.-336. Business Farming.-337. I segumes and Inoculation.-338. The U'se of Manures.-339. In Conclusion. 


\section{LIST OF ILLUSTRATIONS}

Page

1. Physical Features of North Ameriea Frontispiece

2. Precipitation Zones of the World - - - 3

3. Map Showing the Northern Limits of sone crops and trees - - - - - - - 7

4. Nature's Map of the Prairie Provinces - -8

5. Preeipitation Zones in Canada - - - - 14

6. Average Aunual Precipitation - - - - 15

7. Monthly Distribution of Precipitation in

Canada - - . - . - . . - 16

8. Monthly Distribution of Precipitation at

Different Representative Points - - - 17

9. Precipitation at Swift Current, Sask. - - 18

10. Average Deptl of Snowfall in Wéstern

Canada - - . - . - . - 19

11. Variations from Normal Precipitation - - 2.2

12. Temperature Kones of Canada - - - - 26

13. Average Temperature by Months at Representative Points - . - - . - 27

14. Frost Free Period at Different Points - - 2?

15. Temperature \%ones of Canada - - - - 31

16. Hours of Possible Sunshine Daily in Summer 3;

17. Rock Weathering - - - - - - - 39

18. Soil Surface Map of Iowa - - - - - 4른

19. Pot Cultures - - - - - - - 47

20. Illinois Fertilizer Experiment - - - - 59 xvii. 
xviii.

Page

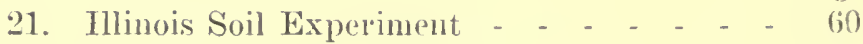

22. Illinois Soil Experiment - - - _ _ - 61

23. Rothamstead Experiments - - . - - - (i3)

24. Soil Bacteria - _ _ _ _ - _ - - 69

25. Noclules on the Roots of Alfalfa - - - - - T:

26. Bacteria in Relation to Soil Building - - 74

27. Wheat Under Irrigation Near Strathmore,

Alberta - - - _ _ _ _ - - 79

28. Hauling Alfalfa Grown Uuder Irrigation at Coaldale, Alberta - _ - _ + - - 82

29. Well Tilled Field of Potatoes - _ _

30. Sugar Beets Growing on Irrigated Iand North of Brooks, Alberta - - - - 87

31. I View of a I'ortion of the Experimental Farm at Brandon - _ _ - - - 90

32. Winter Rye at Indian Head, Saskatchewan ?:

33. Flax in Bloom in Śouthern śaskatchewan 94

34. Harvesting Cor'll at Brandon, Manitoba - 96

35. Cutting Sweet Clover at Saskatoon, Saskatchewan - _ _ _ _ _ _ _ _ _ _ 98

36. Sudan Grass at the Manitoha Igricultural College

36a. Harvesting Short Wheat with a Heacler in

Southern Alberta - - - - - - $10^{\circ}$ )

37. 'Types of Bottoms - _ _ _ _ _ - 107

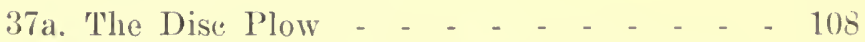

37b. Subsoil Attachment on Mouldboard Plow - 109

37e. 'lypes of Coulters _ _ _ _ _ _ -110

38. The Plow and Plowing - _ - _ _ - - 111

39. Types of Cultivators - _ _ - _ - 113

40. Types of Disc IIarrow - _ - _ _ -

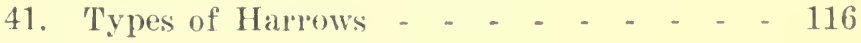


xix.

Page

42. Types of Soil Firmers - - - - - 117

43. Types of Drills - _ _ _ - _ - - 119

44. Breaking with Tractor - - - - ' - 120

45. Breaking with Oxen - _ _ - - - - 12t

46. June Breaking Pays - - - - - - - 12.)

47. Improper Breaking for Dry Areas - - - 127

48. Improper Breaking After Disking - - 129

49. In Breaking the Furrow Slice Should be Turned over Flat - _ _ _ _ $~ 130$

50. A Good Job of Breaking on Medium Light Soil - _ - _ _ _ _ _ _ 132

51. Breaking Serub Land in Manitoba - - - 133

52. Typical Scene in the Park Belt of Manitoba 137

53. Removing Small Trees with Tractor - - 138

j4. Pulling 'Trees with Tractor - _ . - $~ 139$

55. Serub Cutter - - _ _ _ - - - 140

56. Plowing and Disking Burned-over Scrub

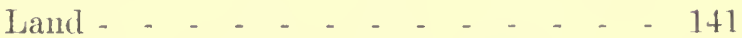

57. How Strub Land Looks After Plowing - - 142

58. Renoving Roots and Brush _ - _ - 144

59. Harvesting Wheat near High River, Nherta 147

60. Effect of Disking Stubble Land - - - 150)

61. Effect of Disking Before Plowing - - - - 15:

6:2. Typical seene at a Plowing Matcl - - 1,it

63. 'Tractor Plowing on Stubble Land - - 1.56

64. Horses Plowing on Stubble Land - - - 1.59

(6.). Summary of T'ests - _ _ _ - - - 16it

66. Cultivating Corn, Gladstone, Man. - - - 1 lis

67. Potatoes Linder Irrigation North of Brooks,

Alberta - - - _ - . . - 171

68. Harvesting Mangels in Manitoba - - - 173

69.). Sheep Pasturing in Rape - _ . . - 17.) 
XX.

70. Cracks in Heary Land - - - - - 177

71. Summary of Tillage Tests on Fallow Land at Saskatoon - $\quad$ - $\quad$ - $\quad$ - $\quad$ - $\quad$ - 180

7.2. Wheat After Alfalfa on Blandon Experimental Farm. - _ _ _ _ _ _ 183

73. Summary of Rotation Tests at Saskatoon 188

74. Oats on Irrigated Alfalfa Sod - - - - 19.2

75. Cattle Wintering Outside, Protecterl only loy

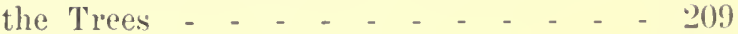

76. Wild Oats - - _ _ _ _ - _ - - 214

77. Tumbling Mustard Piling up against a Fence 217

78. Blue Burr - - -

79. Dandelion - - - - - - - - - - $\quad 2 \cdot 27$

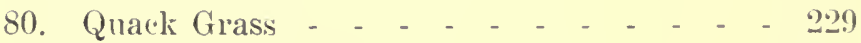

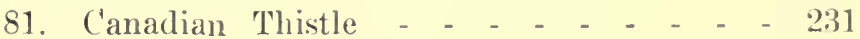

8:. Float Levelling Land for the Border System

of Irrigation - - - $\quad$ - $-\quad$ - $\quad$ - 235)

83. Making Border's for Border System of Irriga-

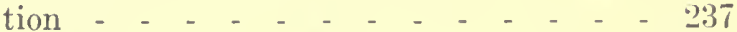

84. The "T" Ditcher at Work - - - - - 238

85. Irrigator at Work - - _ - - - - 240

86. Irrigating Wheat, Stratlmore, Alberta - - 24.

87. Furrow System of Irrigation - - - - 244

88. Map Showing Location of Irrigation Projects

Under Way or Projected - $~-~-~ 245$

89. Seeding and Harrowing on a Large Grain

Farm in Manitoba $\quad$ - $\quad$ - $\quad$ - $\quad$ - $\quad$ - $\quad$ - 249

90. Manitoba Harvest Seene - $\quad$ - $\quad$ - $\quad$ -

91. Threshing Wheat in Manitola - - - - 2.5

92. Winter Rye Lessens Soil Drifting - - - - - -70

93. Rotary Rod Cultivator - - - - - - 27:3

94. IIanling Manure with a Spreader - - - - ¿2St 
95. Cereal Test Plots at Beaver Lodge, Grande Prairie District, Northern Alberta - 286 96. Wheat Field at Fort Vermilion, Peace River 288 97. The Windstorm at its Height - - - - 290 97b. After the Windstorm - - - - - - 290

98. Harvesting Winter Wheat with a Header in Kansas - - - - - - - - - 297

99. Black Amber Sorghum in Kansas - - - 306 100. Disking Behind the Binder to Conserve Moisture in Nebraska -

101. Sweet Clover - - - - - - - - 314

102. Sunflowers for Silage, Agricultural College, Winnipeg - - - - - - - - 332

103. C'utting Western Rye Grass and Alfalfa at Brandon Experimental Farm - - - 338

104. Alsike Clover' and 'Timothy, Laeombe, Alta. 343 105. Bamer Oats on the Noble Farms in Southern

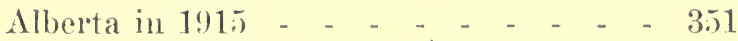
10.a. Combined Harvester and Thresher - - 353 106. Cattle on the Range in Northern Saskatelewan -

107. Batom Hogs in the Making - - - - 360 108. Manitoba kalm Yard Seene, in Winter - 364 109. Dairy Herd in Red River - _ _ - 368 110. Preeipitation '/ones of the three Prairie Provinces - - - - - - - - 380

111. Precipitation Recold. Winnipeg. Man. - - 381

112. Precipitation Record, (2u'Appelle, Sask. - 38113. Precipitation Rerord, Battleford, Sask. - 383 11t. Preeipitation Recoud, Medieine IIat, Alberta 384 115. Preceipitation Reeord, Calgary, Alberta - 3.5. 116. Precipitation Record, Edmonton, Alberta - 386; 



\section{DRY FARMING IN WESTERN CANADA}





\title{
Dry Farming in Western Canada
}

\author{
CHAPTER I.
}

\section{THE DEVELOPMENT OF DRY FARMING}

Previous to fifty years ago lands having less than 20 inches of precipitation per year were generally considered unfit for crop production, except where artificially watered at great cost by irrigation ditches. Within the memory of men now living, the practice of crop growing in semi-arid regions,- - those receiving between 10 and 20 inches of rainfall per year-has developed, until at present mueh of the so-called "dry land" of carlier days is in many countries being successfully eropped as a result of the intelligent application of suceessful dry farming practices.

One quarter of the earth's surface receives less than 10 inches of precipitation annually. Rather more than onequarter receives from 10 to 20 inches. On about onefifth of the land area between 20 and 40 inches falls and on one-fifth between 40 and 80 inches, while the balance, about 5 per cent. of the total, has a precipitation of over 80 inches per year. The climate of Western Canada falls 
in the second class; judged by the rainfall it is, except for some small areas, "semi-arid".

1. Dry Farming Defined.-Dry farming is a popular term used to designate the methods of erop and soil management found to be profitable in areas of light rainfall. The specific practices which together comprise the system are not new, but the organization of them and their intensive application in areas of low rainfall have resulted within the last generation in giving to the system the special name "dry farming". This system has accomplished much in the semi-arid regions of North America, even though its most intelligent practice does not make erops grow in the absence of rain. Dry farming is nothing more nor less than the employment of common-sense methods of meeting the rainfall conditions that exist by practices that have been slown to result in increased yields or greater profit.

To those who have the inclination to search them out the secrets of dry farming, if such its principles may be called, are as an open page; to others the attempt to farm in areas having less than 15 inches of precipitation is not likely to prove an easy road to wealth unless they are fortunate enough to have sueeessful neighbors whose methods they may imitate. An understanding of its principles combined with the will and experience neeessary to their application are fundamental necessities to suceessful dry farm practice.

The factor that generally controls the yield on the poor soils of humid elimates is plant food; in northern elimates the absence of suffieient heat is frequently the limiting factor; while in dry areas the thing that limits the yield more frequently than any other is lack of suffieient moisture. The more important practices of erop 
THE DEVELOPMENT OF DRY FARMING 3

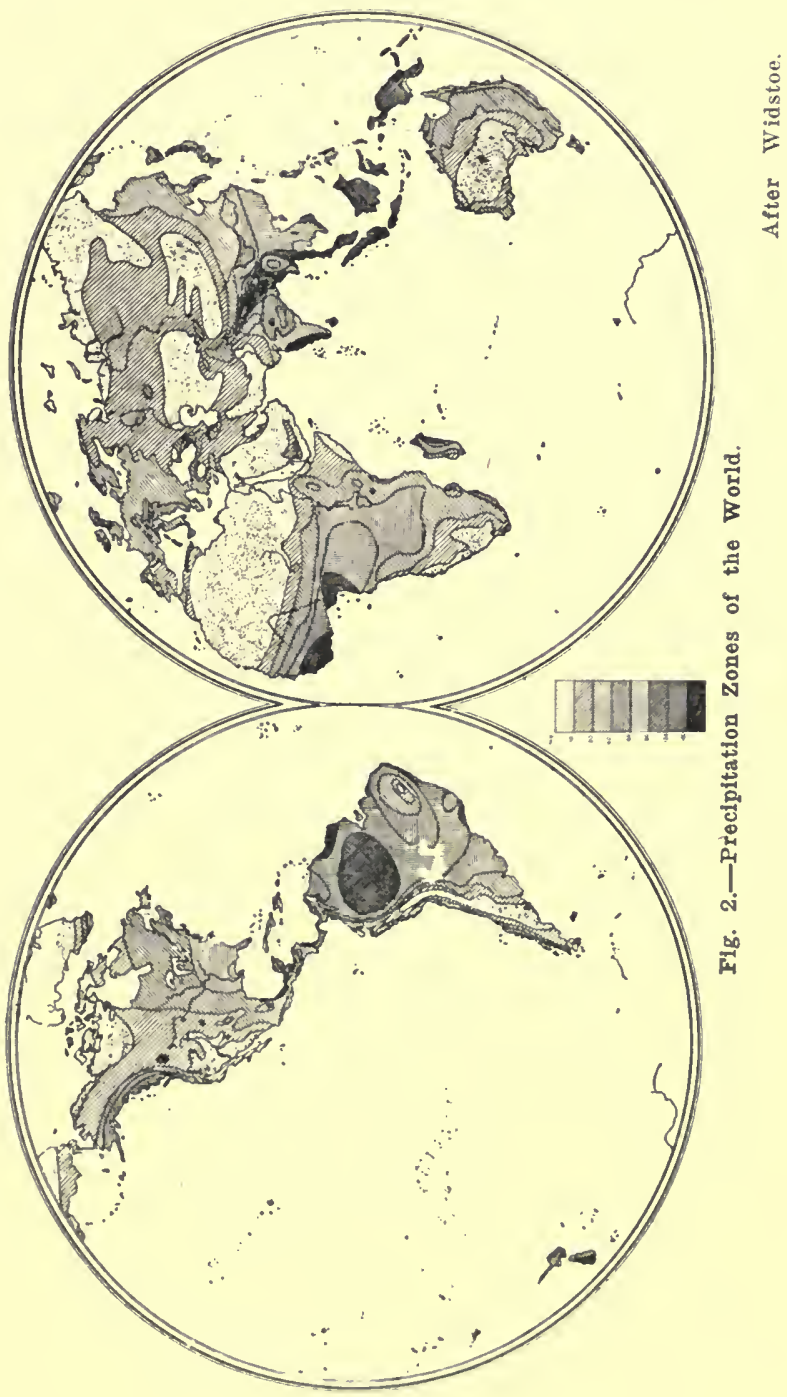


growing in humid regions relate to the maintenance or increase of the supply of plant food in the soil; in northern climates the chief consideration, at least in the growing of cereals, is to get them ripe before fall frost comes; but in dry areas cropping practices are primarily coneerned with making the best possible use of the moisture that falls.

The principles underlying crop produetion are the same the world over, but the relative supply of plant food, heat and moisture under different elimatic and soil conditions determines the relative importance of the different farm practices that are commonly used in growing crops. The supply of the factor that generally limits the yield in any given region largely determines the general trend of farm practice there, and, as in the case of the semi-arid regions, sometimes gives to the practices followed the name by which the system is commonly known.

2. History of Dry Farming.-Before the present dry farming movement began, the Chinese on the dry lands of Western China and the American Indians in the arid States and in parts of Mexico are known to have grown crops under very dry conditions. It is reported also that crops were produced in the dry parts of northern Africa without irrigation. The ancient civilization of the Orient, the Euphrates Valley, Palestine and Egypt developed in dry climates, but chiefly in areas where irrigation was practised. It is probable that many of the dry farming practices are vely old, but such methods as may have been used in early days must have been largely lost to Americans, most of whom came from humid countries.

The recent development in America does not appear 
to have been based on any knowledge of aneient methods. Here the system grew up independently in each of four different parts of the continent, (1) in the State of Utah, in the southern part of the inter-mountain region, (2) in western Kansas and Nebraska, the eentral part of the great plains, (3) in Western Canada, in the northern great plains, and (4) in California and Oregon. In each of these areas a system of crop growing developed apparently without knowledge of the methods followed in any of the others, until the popular "dry farming" movement was initiated within the last thirty years.

To the Mormons of Utah belongs the distinction of being the first eivilized people to grow erops on "dry" land in America. Upon their arrival in Salt Lake City in 1847 only irrigated land was used for crop growing, but in the sixties it was observed that cultivated land above the ditch was eapable of produeing fair erops without irrigation. In the early eighties dry farming beame an established system in many of the unirrigated portions of the state.

In California dry land cultivation commeneed in the late sixties. Two decales later the colonization of much of the dry land of Nebraska and Kansas was attempted without sueeess, but in the late eighties more satisfactory practiees eame into vogue and the tide of emigration commeneed to return to the abantoned homesteats of the earlier era only to be turned eastward again by unfavorable seasons in the middle nineties. It was about this time that $\mathrm{H}$. W. (ampbell of "]) ry larm" fame was getting his early experience in the diy part of sonth Dakota. The ideas he developed there and later in Nebraska, where smmmer tillage freefuenty gave him largely inereased yields, were organized and published at 
various times during the first few years of the new ientury.

In Western Canada the eolonization that followed the building of the Canadian Paeific Railway in the eighties slowly spread itself westward from the Red River Valley. The first settlements developed along the North Dakota boundary, along the main line of the Canadian Pacifie Railway west to Qu'Appelle and Moose Jaw and to the northwest in the Yorkton and Prince Albert distriets. It was in the Qu'Appelle Valley that the first organized effort to introduce the summerfallow into general farm practice originated. At the time of the last Riel rebellion in 1885 most of the settlers hired out their horses and oxen with the military transport, the finaneial allowance being so mueh more than they loped to get from the enltivation of their land. A few remained behind and after putting in what erop they could, commenced to plow the land that was still unsown. The following year, 1886, it was observed that the land which had borne no erop the previous season, but which had lain fallow, produeed a much better erop than the other. This marked the beginning of the summerfallow as a recognized good farming practice in the central Canadian West. The methods of fallowing were later studied and improved upon by Mr. Angus MeKay, who, from 1886 to 1917, was Superintendent of the Experimental Farm at Indian Head.

It is interesting to note that while the farmers of Saskatehewan lave been given eredit for being the first to practise the fallow system extensively in Western Canada, the benefits of this practice were not unknown to the Selkirk settlers, the first white people to take up land in the Canadian prairies. 
In "The Beginnings of Agrieulture on the Prairies" Dr. E. H. Oliver, who carefully examined the early reeords of the Selkirk settlers, states as follows: "After a series of trials on the part of the settlers it was found that fall plowing and fallow yielded the best crops. Alexander Ross, who could secure only 52 bushels from 10 bushels by the spring plowing of a worn-out field, was able, out of the second field, left fallow for two consecu-

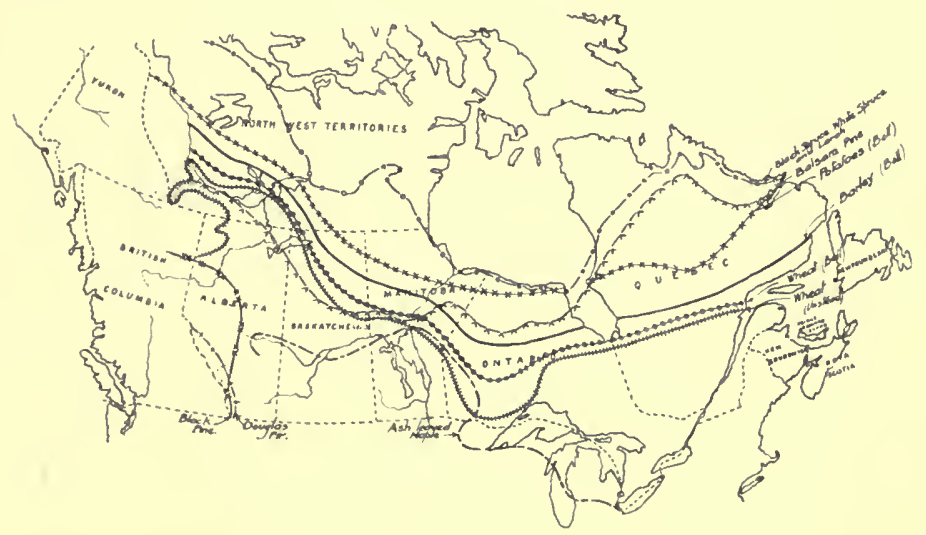

Fig. 3.-Map Showing the Northern Limits of Some Crops and Trees.

tive years, during which it was plowed three times, to seeure no less than 280 bushels from 8 bushels sown." It thus appears that while the practiee of fallowing was brought foreibly to the attention of the Saskatehewan pioneers after the last Riel Rebellion and that it was not until this time that it became a general practice, yet its value was not unknown in the West as early as the middle of the last century.

In reeent years the United States Department of Igriculture, the different State Experiment Stations, the Ex- 
perimental Farms of the Canadian prairies and the Dry Farming Congress have each studied the practices of Dry Farming and each has contributed much towards putting the system on a permanent basis. How much of its success is due to the organization and application of the facts of the science of erop production, and how much to other factors such as the higher prices of the last twenty years, and the contribution of the implement

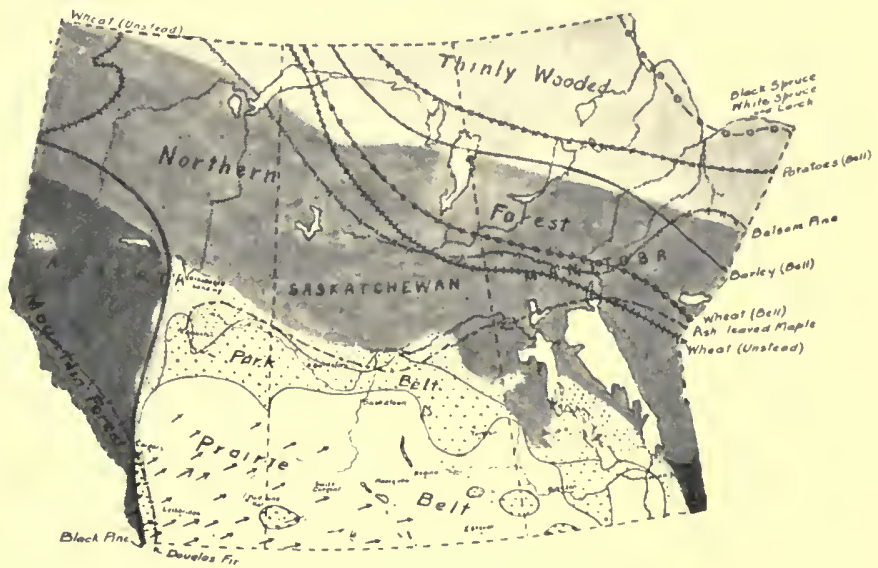

Fig. 4-Nature's Map of the Prairie Provinces.

(Arrows indicate the chinook belt.)

companies in the way of labor saving machinery, history alone will determine.

3. Where Dry Farming Applies.-One or more of the established dry farming practices should be used wherever moisture is the limiting factor in the yield of crops. This condition, of course, obtains chiefly in the areas of low rainfall, but may be found in other places where 
excessive evaporation or periods of drought or other cause results in moisture becoming the limiting factor.

The preeipitation zones of Western Canada are indicated in the following chapter. The boundaries of these are based upon the limited rainfall and snowfall data available. They will, no doubt, be modified and more aceurately located as more records be:ome available, but in the meantime they furnish us with the approximate boundaries of the precipitation zones.

The areas of different evaporation cannot be mapped owing to lack of data. The Chinook region, is, however, generally believed to have the greatest evaporation, and the northeastern portion of the Prairie Provinees to have the least.

Judging from the precipitation reeords and the data for spring and fall frosts as well as from the costly experienees of farmers, it would appear that while several of the practices of dry farming should be applied wherever land is tilled, the extreme practices of this system should be applied in Western Canada only in the Chinook belt, in a modified form they should be used in the prairie area outside the Chinook belt, while in a still more modified form they may be used in eastern Manitoba, the park belt and the wooded areas. (See "Nature's Map of the Prairie Provinees").

It should perhaps be emphasized here that in growing grain erops in places where fall frosts are more to be feared than dronght, less attention should be given to moisture storage and more to getting erops ripe. Both moisture conservation and early maturity may be desirable but where added moisture results in too late ripening it must be sacrifieed in areas where erops are grown for their seeds. If forage erops only are to be 
grown, or where grain erops are to be grown for hay, dry farming may be praetised even in the far North, beeause with these erops maturity is not an essential condition for either a good yield or good quality. 
CHAPTER II.

\section{THE CLIMATE OF WESTERN CANADA}

\section{In Its Relation To Crop Production.}

Under. good systems of management three sets of factors determine the productiveness of erops in any region:

1st. The elimatic eonditions.

2nd. The soil conditions, and

3rd. The suitability of the erops grown.

4. Climatic Conditions the Chief Causes of Low Yields.In the year 1914 the small amount and the unfavorable monthly distribution of precipitation caused a erop failure in the drier parts of Alberta and Saskatehewan. In 1907 and 1911 early fall frosts lowered the net profit on the western grain erops to perilously near the zero mark. In 1918 a July frost completely destroyed many thousands of acres of wheat in the blossom stage in the northern parts of the Prairie Provinces; while in 1916 a eombination of high temperatures, high precipitation and high atmospherie humidity in the months of olune, July and August provided very favorable conditions for the development and spread of rust and thus lowered 
the value of the Western Canadian wheat erop between fifty and one hundred million dollars.

The elimatie conditions, at least in the first few years of land eultivation, are among the ehief eauses of poor crops, and unfortunately they are largely beyond man's power to ehange. This, however, is but another reason why our climate should be better understood. If we eannot ehange its undesirable features perhaps we ean avoid them; if it has any favorable aspects perhaps we ean take greater advantage of them. A knowledge of the essential facts coneerning our climate should enable us gradually to choose more suitable erops and to adapt our rotation and management practices to the climatie conditions that have been fixed for us and that eannot be altered by us.

5. The Factors of Climate.-The term "elimate" means the sum total of the atmospheric eonditions that make up our "weather". Weather is "the eondition of the atmosphere at a given time or over a limited period", while elimate is a more general term meaning the average condition of the weather for the different seasons of the year.

The ehief determiners of elimate are latitude, altitude and relationship to large bodies of water, forests and mountain ranges. It is suffieient here to say that ours is a "eontinental" or inland elimate, in a northern latitude, and far removed from the moderating influences of large bodies of water, but influenced considerably by our nearness to the Rocky Mountains, and by gradual variations in altitude ranging from less than 1,000 feet in the east and far north to more than 4,000 feet in the upper parts of the foothills. 
The chief factors of elimate in order of their relative importanee to the agrieulture of Western Canada are:

1. Preeipitation: (a) amount per y*ear; (b) geographie distribution; (c) monthly distribution; (d) form (rain, snow, hail, dew); (e) variations from the average; and (f) evaporation.

2. Temperature: (a) the number of days between spring and fall frosts; (b) the average monthly temperature; (c) the range of annual and daily temperature.

3. Wind: (a) velocity; (b) temperature; (c) humidity, and (d) direetion.

4. Atmospheric humidity.

5. Light during the growing season.

6. Altitudes and forests.

6. Importance of Precipitation.-Moisture in the soil is essential to crop production. It is needed both as a plant food and as a carrier of plant food. Under semi-arid conditions more than a quarter of a ton of water is taken in through the roots and passed out through the leaves in order to earry enough food into the plant to produce one pound of "dry matter".

One acre inch of water weighs abont 113 tons. Assuming that 700 pounds* is the average requirement for one pound of dry matter in wheat and, for easy calcula. tion, that half the dry matter of wheat is in the stems and leaves, it would take 1,400 pounds of water to pro-

* Recent investigations by Hopkins at Olds, Alberta, indicate that much less than this amount is required on rich prairie soil in high latitudes. 
duce one pound of threshed grain, or over one ton to produce $1 \frac{1}{2}$ pounds of wheat. At this rate if it were all conserved and utilized, one acre inch of water would produce over $2 \frac{1}{2}$ bushels of wheat and 8 inches would produce at least 20 bushels per acre.

Our precipitation is about twice 8 inches, or more, and we crop our land only three times in four years, or

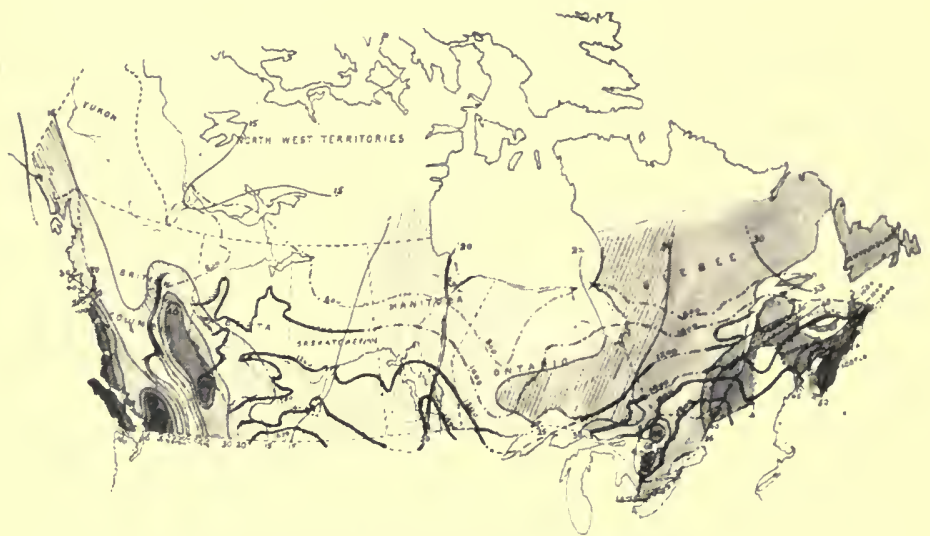

Fig. 5.-Precipitation Zones in Canada.

Approximate boundaries based on Meteorological Service data. (See Figure 110 for more recent detailed map).

twice in three years, yet our average yield equals less than the amount eight inches of moisture might produce. The loss through "run-off", secpage, evaporation and transpiration through weeds accounts for this poor showing.

From these figures it will he apparent that the precipitation in Western Canada is one of the chicf limiting factors in crop yiclds; it suggests the desirability of more efficient control of the limited amount of moisture that falls. 
7. Amount of Precipitation per Year.-The average annual preeipitation in representative districts in Western Canada for 25 years as compared with that in some other agricultural regions is indicated by the accompanying ehart.

These figures show:-

(1) That the preeipitation in Western Canada is rather more than in some eountries where agrieulture is practised, but is very little over half as much as in

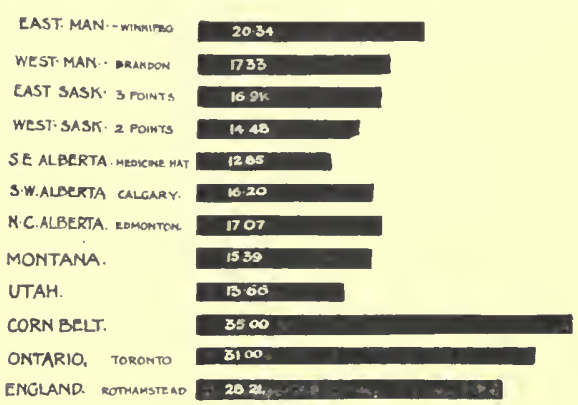

some of the older agricultural regions from which our settlers have eome.

(2) That nearly the whole of the Canadian west reeeives more than 13 inches and less than 20 inches per year.

(3) That the area of lowest precipitation is in southeastern Alberta and soutliwestern Saskatehewan, and the supply increases in every direction from this centre. The increase is greater both east and west than north.

The two chief inferences from the data are,-1st. that the storage, conservation and efficient utilization of moisture are of very great importance, and and, that extreme practiees of "dry farming" would seem desirable in the drier areas. 
8. Geographic Distribution of Precipitation.-The figures reported in the preeeding section show that all parts of Western Canada are not equally favored with respeet to precipitation. The precipitation map shows the outlines of what may be ealled the moisture zones in the three Prairie Provinees. While insuffieient data are available to insure that the boundaries represented are absolutely correet, yet the map is at least a safe general guide to the precipitation zones.

9. Monthly Distribution of Precipitation.-The total preeipitation per year is not a satisfactory measure of

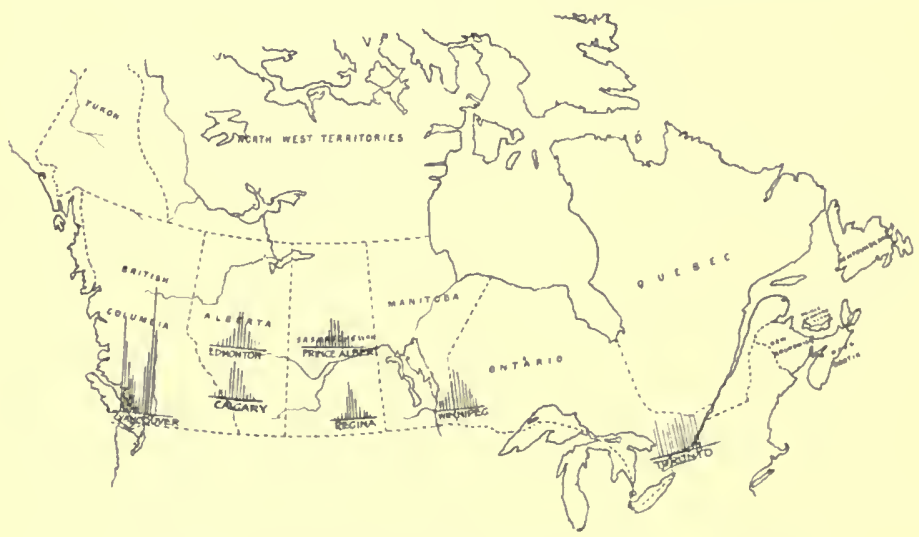

Fig. 7.-Monthly Distribution of Precipitation in Canada.

Note relatively heavy rainfall in the summer months in the Prairie Provinces as compared with low precipitation at Vancouver for the same months and the average distribution throughout the year at Toronto.

the moisture supply available for erops. The proportion that falls in the season the crop is growing is of far greater importance than the anmul amount. The following table gives the average precipitation per month for several years at a number of points. 


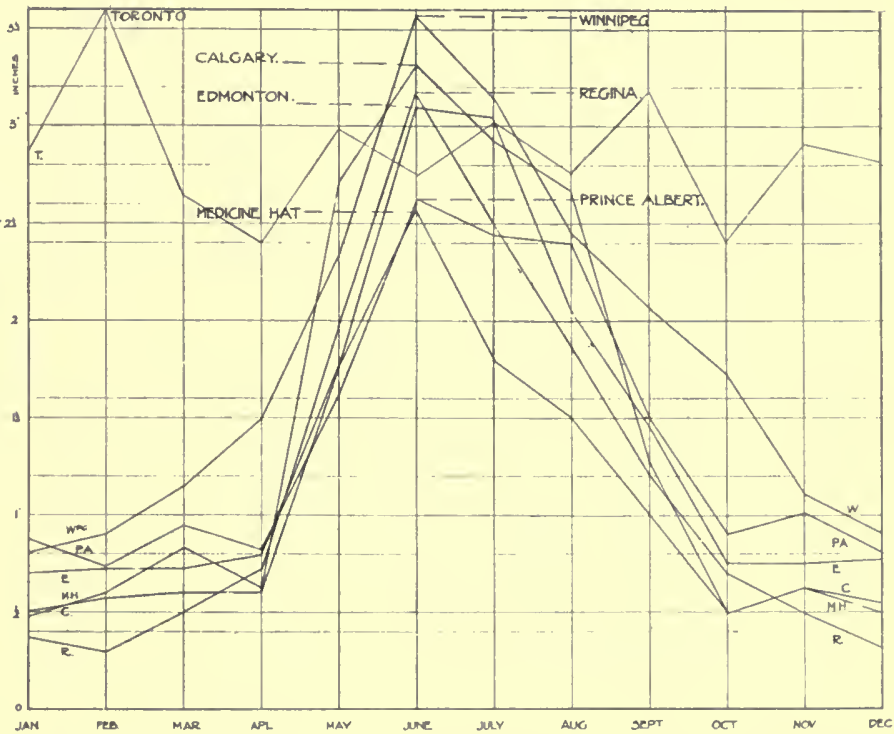

Fig. 8.-Monthly Distribution of Precipitation at Different Representative Points.

'Гавц. I.-The Average Mean Monthly Precipitation at Representative Points in the Prairie Provinces.*

Station Jan. Feb. Mar. Apr. Miay June July

$\begin{array}{llllllll}\text { Calgary } \ldots \ldots \ldots \ldots & .47 & .59 & .74 & .63 & 2.72 & 3.32 & 2.93 \\ \text { Edinonton } \ldots \ldots \ldots & .69 & .72 & .73 & .79 & 1.78 & 3.10 & 3.05 \\ \text { Medicine Hat } \ldots \ldots & .56 & .58 & .61 & .61 & 1.78 & 2.57 & 1.80 \\ \text { Prince Albert } \ldots \ldots & .88 & .74 & .95 & .83 & 1.53 & 2.63 & 2.41 \\ \text { Regina } \ldots \ldots \ldots \ldots & .37 & .29 & .49 & .73 & 1.98 & 3.17 & 2.49 \\ \text { Winnipeg } \ldots \ldots \ldots \ldots & .85 & .90 & 1.15 & 1.48 & 2.35 & 3.58 & 3.15\end{array}$

Station Aug. Sept. Oct. Nov Dec. Year

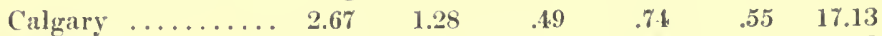

$\begin{array}{lllllll}\text { Edmonton } \ldots \ldots \ldots \ldots & 2.05 & 1.46 & .75 & .74 & .77 & 16.63\end{array}$

$\begin{array}{lllllll}\text { Medicine Hat } \ldots \ldots & 1.52 & 1.00 & .51 & .72 & .49 & 12.75\end{array}$

$\begin{array}{lllllll}\text { Prince } A \text { lbcrt } \ldots \ldots . & 2.40 & 1.49 & .89 & 1.04 & .79 & 16.61\end{array}$

$\begin{array}{llllllll}\text { Regina } \ldots \ldots \ldots \ldots \ldots & 1.86 & 1.19 & .70 & .48 & .36 & 14.11\end{array}$

$\begin{array}{lllllll}\text { Winnipeg } \ldots \ldots \ldots \ldots & 2.45 & 2.07 & 1.73 & 1.10 & .91 & 21.69\end{array}$

* From Canada Year Book reportiner Dominion Meteorologieal Serviec data-Calgary 20 years, Edmonton 25, Prince Albert 20, and Winnipeg 0 vears. Regina data from "lhe Climate of Western Canada" by Stupart, 

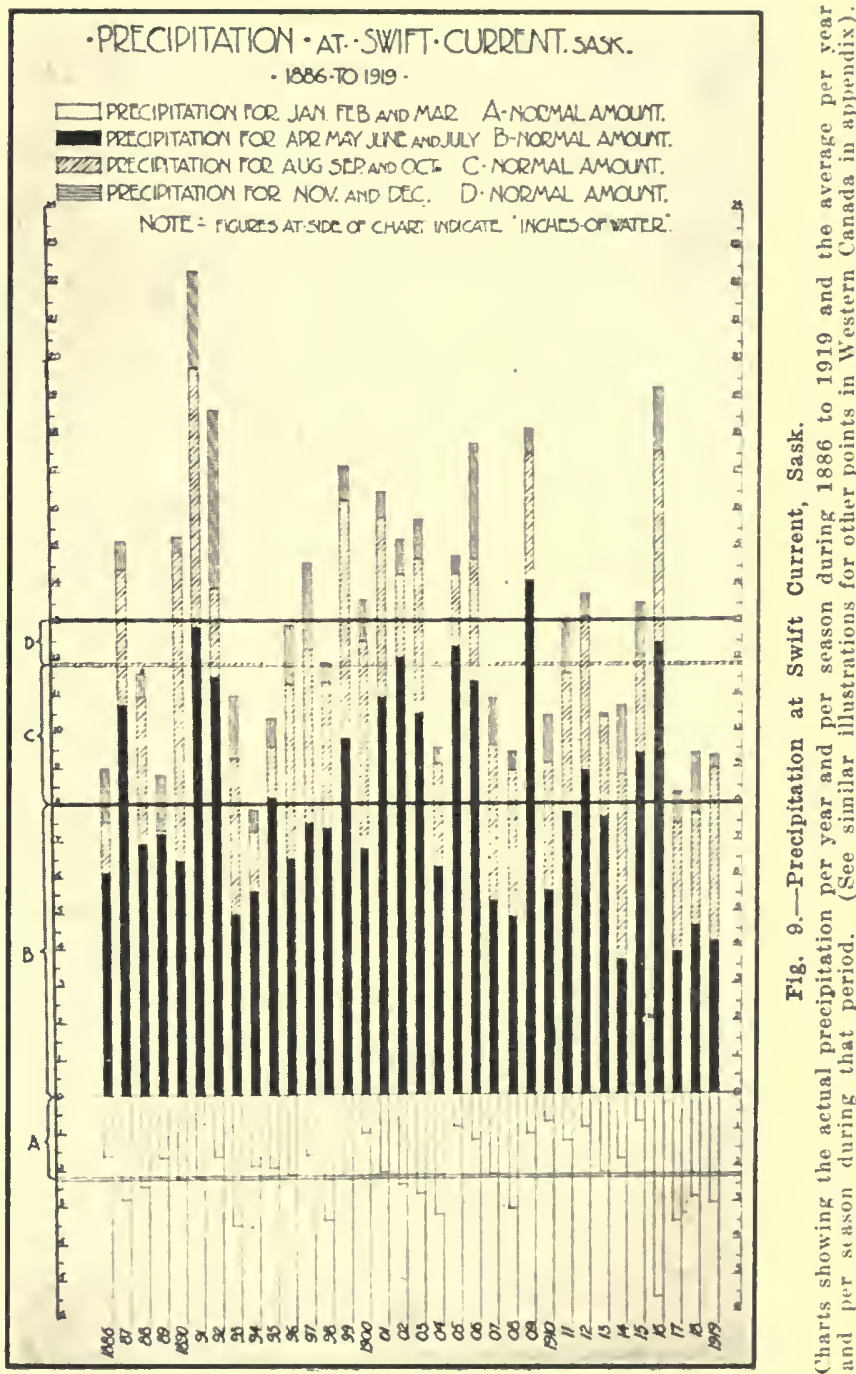
From the figures in table I. a number of very important observations may be made. Among these are:

(1) From 50 to 60 per cent. of the total precipitation falls in the four "growing" months, May, June, July and August. In the districts of heaviest precipitation this is nearly as much as is received in the same period in Ontario or in the midland counties of England.

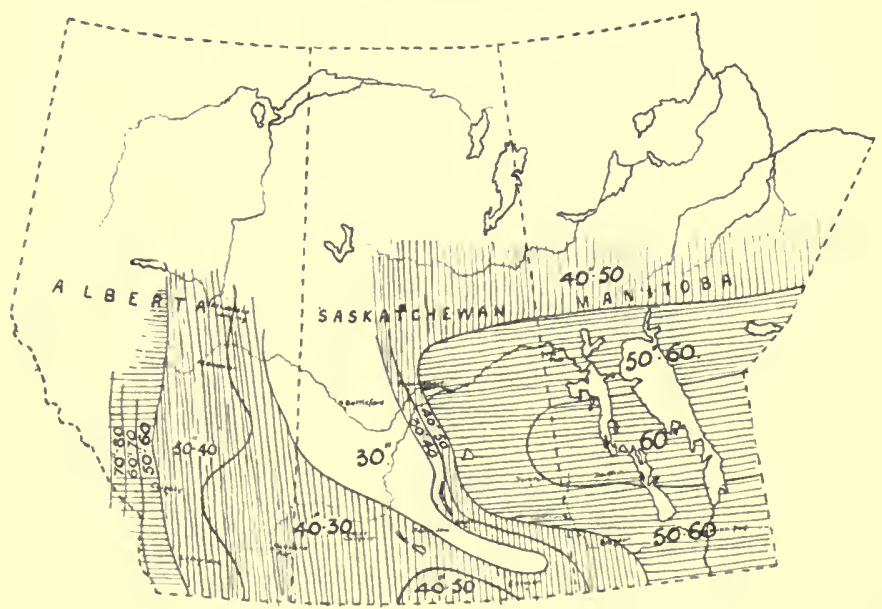

Fig. 10.-Average Depth of Snowfall in Western Canada. -From Meteorological Service Reports.

(2) June and arly July is the rainy season. 'This fact is of considerabale importance in relation to the conservation of moisture by fallowing. It is the chief faetor that determines the best time to plow the fallow and the character of the other neessary work that shond be done on it.

(3) The sproing and antmmu seasons ale nswally quite dry. The former sugrests the noressity of having the 
seed bed in a good moist condition at seeding time, while the dry autumn results (a) in unusually favorable conditions for harvesting, euring and threshing grain erops, (b) in seriously lessening the amount of fall pasturage seeured from perennial erops, and (e) in lessening the value of fall plowing as a means of eonserving moisture and causing weed seeds to germinate.

It is interesting to note also that, as compared with either Toronto or Vancouver, (see map), while our total precipitation is much less, the monthly "distribution" is very favorable. In fact, with either the Vancouver or Toronto type of distribution here, we should be unable to produee crops profitably.

The monthly distribution and average annual snowfall at representative points is as follows:-

TABLE. II.-Monthly Distribution of, and Average Annual Snowfall.*

Station Jan. Feb. Mar. Apr. May June July

\begin{tabular}{|c|c|c|c|c|c|c|c|}
\hline Calgary ......... & $4.9^{\prime \prime}$ & $6.3^{\prime \prime}$ & $7.1^{\prime \prime}$ & $3.8^{\prime \prime}$ & $2.4^{\prime \prime}$ & ... & \\
\hline Edinonton & 6.0 & 7.3 & 6.3 & 3.5 & 1.4 & & \\
\hline Medicine fiat .... & 6.8 & 7.7 & 6.0 & 2.5 & .6 & .. & \\
\hline Prince Albert .... & 9.0 & 7.0 & 8.1 & 4.4 & 1.4 & & \\
\hline Qu'A ppelle & 5.8 & 8.7 & 8.9 & 8.0 & 2.1 & $\cdots$ & \\
\hline Winnipeg $\ldots \ldots \ldots$ & 8.7 & 9.4 & 8.8 & 4.3 & 1.3 & ... & \\
\hline Station & & Aug. & Sept. & Oet. & $\begin{array}{l}\text { Nov. } \\
8.2^{\prime \prime}\end{array}$ & $\begin{array}{l}\text { Dec. } \\
6.4^{\prime \prime}\end{array}$ & ir \\
\hline $\begin{array}{l}\text { Calgary } \ldots . . . \ldots \\
\text { Edmonton } \ldots \ldots\end{array}$ & & $\cdots$ & & 4.2 & $\begin{array}{l}0.2 \\
5.6\end{array}$ & $\begin{array}{l}0 .+ \\
6.5\end{array}$ & \\
\hline Medicine Hat ... & & $\ldots$ & .5 & 1.4 & 7.6 & 5.2 & \\
\hline Prince Albert ... & . & $\ldots$ & .1 & 2.5 & 8.8 & 6.7 & \\
\hline Qu'A ppelle ..... & & $\ldots$ & 1.1 & 5.5 & 8.2 & 6.0 & \\
\hline Winnipeg . . . . . . & $\cdots$ & ... & & 1.3 & 9.8 & 7.6 & \\
\hline
\end{tabular}

The average depth of snow in the southern parts of all three prairie provinces is clearly indieated in the snowfall map. The melting of the snow is more frequent and

*From "'The Climate of Canada", by Stupart. 
the evaporation of the resulting moisture is greater in the prairie areas than in the wooded and semi-wooded parts, and the most frequent melting and greatest evaporation oceurs in the Chinook belt of soutlern Alberta and southwestern Saskatchewan.

10. The Form in which the Precipitation 0ccurs.Preeipitation includes all the moisture that falls from the clouds to the earth. Rainfall is the most important but snowfall is also important. Hail and dew are otler forms.

Snowstorms oeeur earlier than November and later than March, in fact, flurries may oceur after th" crop is up or before it is threshed. And snow that falls after March and before November may interfere with farm operations but it always functions as rain so far as the farmer is eoneerned and is generally very much appreciated by lim when it comes in the spring.

The snowfall generally ranges between 30 inches and 60 inches per year, although less than 15 inclies was reported twice at Battleford and more than 80 inches twice at Wimnipeg. The area of lowest average snowfall runs in a northwesterly direction from sontheastern Saskatehewan to northeastern Alberta, including Areola, Regina, Saskatoon and Battleford. The amonnt increases rapidly in a northeasterly direction from this area but less rapidly in a southwesterly dirretion until western Alberta is reached. It has alrealy been pointed out that from 50 to 60 per cent. of the total precipitation falls as rain in the May-August period, and that April, September and October precipitation is chietly in the form of rain. In the prairie area any snow that falls in Oetober usually melts in a few days but it has been known to remain on the ground from the early 
days of this montl and to oeeasion considerable loss as a result of interferenee with the harvest of potatoes and roots as well as with the late threshing of eereals. The possibility of snowfall at this time should also have an important bearing on the plans of the stockman for the feeding and management of his animals.

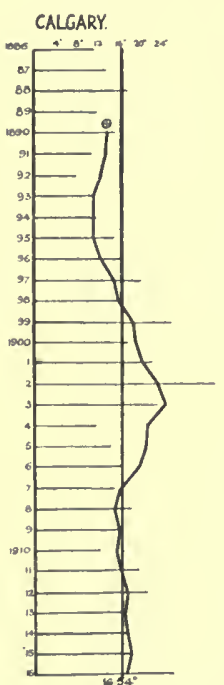

$\oplus$ LINES SHOWING

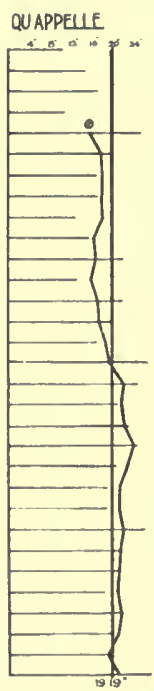

A

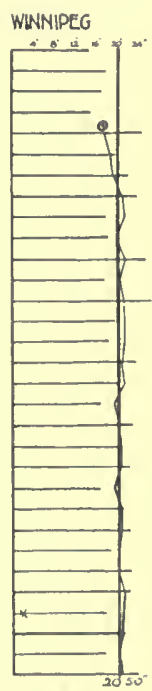

Fig. 11.-Variations from Normal Precipitation. The heavy vertical lines indicate the average precipitation at Calgary, Qu'Appelle and Winnjpeg. The horizontal lines show the actual precipitation by years. The crooked lines represent the average precipitation in five-year periods and illustrate the variations from the normal.

Hail storms are most frequent between the middle of July and the middle of $\mathrm{Au}$ gust. They may occur early in June or as late as the last of September. As to whether some districts are "subject" $t$ " hail and others not, there is much discussion but little reliable data. Most hail insuranee com pa n i e s charge slightly higher premiums in some parts of the foothill country and immediately east of it than in the central and easteru parts. The possibility of hail suggests the advisability of not putting all one's eggs in a single basket, in other words of having some source of reve- 
nue other than a grain crop. We eannot insure against drought or frost but insuranee of grain crops against hail damage is possible and advisable for all who cannot afford to lose a crop.

\section{Wide Variations from the Average Precipitation.} - Three instanees will serve to illustrate the fact that wide variations from the average precipitation are likely to oceur. The avcrage at Calgary for 31 years is 16.54 inches but in one year (1892) it was only 7.91 inches while in another (1902) it was 34.57 inehes. The average for Qu'Appelle is 19.19 inches, but in 1886 it was 10.14 and 1916, 26.5t. The average for Winnipeg for 31 years is 20.50 , but in 1886 only 14.84 inches fell, while in 1899 the precipitation was 27.19 inches. Even the five-year averages depart widely from the normal. the variation appearing to be greatest in western $\mathrm{Al}$ berta and least in eastem Manitoba. Beeause of these wide variations from normal precipitation a more diversified system of apping is likely to prove less risky and therefore in the long run is to be preferren?.

12. Evaporation.-One of the chicf reasons why creps have suffered less from drought in the northern end of the Great Plains region than in those parts of the south where the precipitation is the same, is the lower evaporation in this latitude. Highes rields are invariably secured in the north than from the same precipitation on equally good soils in more southern latitudes. The amount of total precipitation is not as satisfactory information as the amount of the "net" precipitation, which is the total less the evaporation from the soil. Unfortunately data on eraporation is not yet available for points in Western Canala. 
13. Dry and Wet Years at Saskatoon.-The monthly distribution of preeipitation at Saskatoon for the two years 1914 and 1915 and the average for the years 1904 . 1914 are as follows :

TABle III.-Monthly Distribution of Precipitation at Saskatoon in 1914 and 1915.

The total preeipitation while not very different in the years 1914 and 1915 was rather greater in 1914, yet the wheat yield was 15 bushels less in 1914 than in 1915. The frormer is even yet remembered as the "dry" year, while the latter was with one exception the best year we have ever had. The differenee in yields was due chiefly to the unfavorable distribution of moisture in 1914. Note that the "June" rains were but little more than half as heavy as the average and that the Oetober and November rains which eame after harvest were nearly three times as heavy as the average. The heavy erop in 1915 was probably due in large measure to the heavy precipitation in the fall of the preceding year. This kept the erop growing well through the early summer of 1915, and the timely and sufficient showers of late summer "filled" the heads.

14. Temperature Necessary for Germination and Growtl. -The temperatures in degrees $F$. at whieh seeds germinate and at which erops grow best is indieated by the following data from IIaberlandt:- 
TABLE IV.-Temperature Necessary for Germination and Grozoth.*

Crop Germination

Min. Opt. Max.

Wheat ........41

Barley ..........4

Beans .........49

Corn .........49

Pumpkins ......52

Melons
84. 108

84. $\quad 99$

$93 \quad 115$

$93 \quad 115$

$93 \quad 115$
Growth

Min. Opt. Max. 32-40 $77-88 \quad 88-98$

Peas

" " "

$40-51$

$51-60$

60-65
88-98 98-111

98-111 111-122

88-98

It will be observed that the grain erops and peas will germinate and grow at relatively low temperatures, while corn demands more heat and truck erops, like melons, still higher temperatures both for germination and for growth.

15. The Measure of the Heat Supply.-The chief sonree of heat is the sun, although the stars and the interior of the earth also slightly increase the surface temperatures. The sun's heat reaches the earth by direct radiation, by radiation and conduction from the atmosphere, and by warm rains. The soil tempcrature is affected also by the heat given off from decaying plant tissues. The measure of the heat supply is the temperature, and the temperature data that ehiefly concern the farmer are, (1) the average and extreme dates of the last spring and first fall frosts, (2) the average temperature of the growing season, (3) the extremes of temperature in the growing scason, and (4) the total amount of heat received during the growing season. The time and severity of the last spring and first fall frosts fix the length of the growing season for cereals and together with the average temperature of the frost-free season determine, approximately at least, the total units of

* As quoted by Lyon, Fippin \& Buckman in "Soils, their Properties and Management." 
lieat received from the sun during the growing season. It the same time the extremes of low temperature within the growing perioul limit the suecessful growth of the warm weather erops such as corn, sorghum, Sudan grass and certain of the heat-loving vegetables.

16. The Temperature Zones of Canada.-The average temperatures for the year and for the summer for the whole of Canada is shown in Fig. 12. From this it will

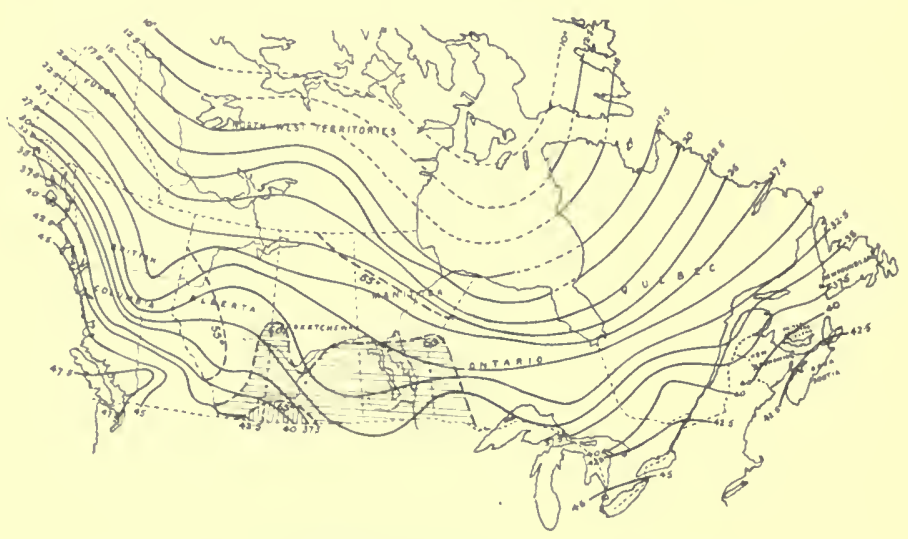

Fig. 12.-Temperature Zones of Canada.

"The shadol area represents the average summer temperature and the unshaded portions the average temperature for the year. From Neteorological Reports.

be observed that southern Alberta and southwestern Saskituhewan and the southern part of the Red River Valley are the warmest for both the year and the summer, and that the temperature decreases in a northeasterly or a northerly direction, but that in the direetion of northern Alberta and northwestern Saskatehewan the temperature derroases less rapidly than in northern Nanitoba. 
17. Spring and Fall Frosts in Western Canada.-The number of days between the last spring frost and the first fall frost and the average date of each is perhaps the most useful temperature information the grain

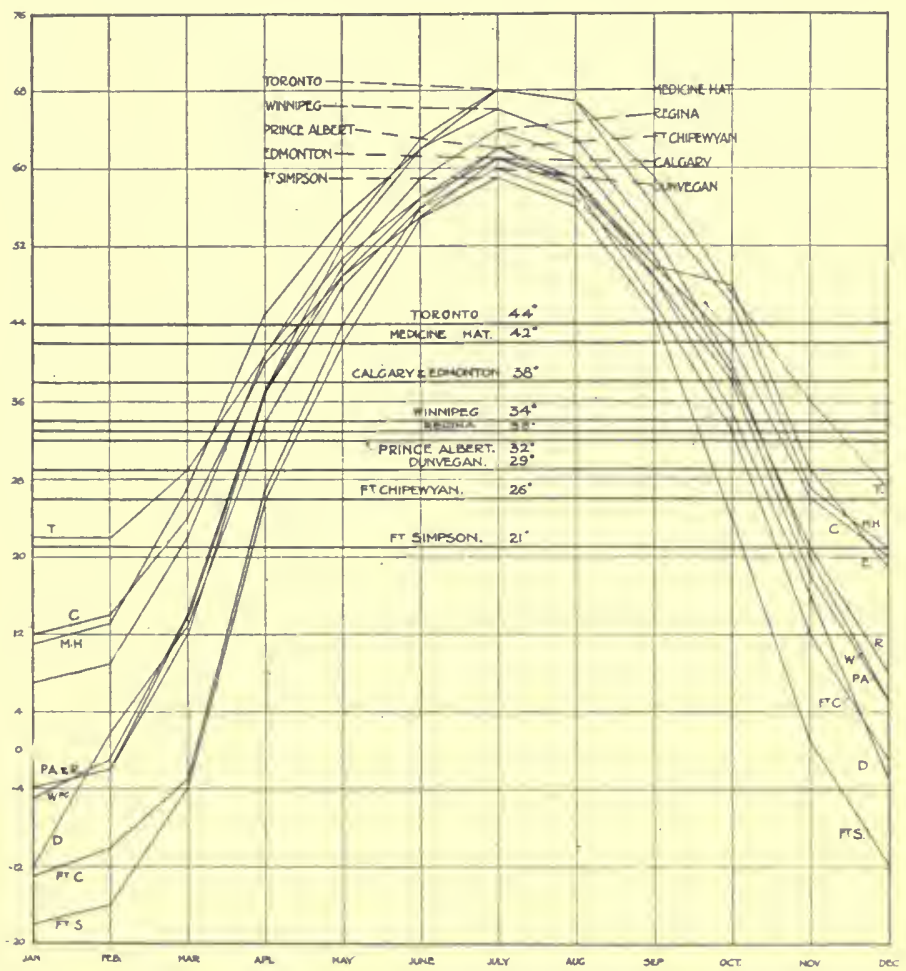

Fig. 13.-Average Temperature by Months at Representative Points.

grower and truek farmer could obtain. The meteorologieal records show that southeastern Alberta, southwestern Saskatehewan (and the Red River valley of Manitoba) have a longer frost-free period than any 
other part of the West and that the number of days between frosts deereases in all directions from there but less rapidly in an easterly direction. The driest part of the West is also the warmest. Too great heed eannot be given to these facts. They suggest that extreme dry farming practices are applieable in the dry warm area, but that "northern farming" or a system that will lessen the danger from frost should be practised in the more humid parts that have but a short time between spring and fall frosts.

The records of the Provincial Department of Agriculture at Regina for the ten years ending 1917 show that in the Provinee of Saskatchewan the soil was suffieiently thawed out by April 18th that the seeding of wheat became general on that date. During these ten years the earliest date on which wheat seeding was general was April 9th and the latest date, May 10th. No reliable records are available to show the average date at which tillage of the soil is prevented by freezing in the fall. Generally in the eentral west plowing may be continued till the end of October, sometimes till early Deeember, but in exceptional rears the ground has frozen hard as early as the first week of October. When the ground is dry in the fall low temperatures do not harden it as they do moist soil, consequently tillage may be continued much later than when the soil is wet.

The temperature records for Sasekatchewan for the twelve years 1904 to 1915 report only one July frost. It is known, however, that in some low spots in at least two of these years small patehes of wheat were frosted when the plants were in bloom in July. The only July frost that did serious harm to grain erops over a large area occurred in 1918, when a considerable percentage 
of the crop in the northern parts of the Prairie Provinces (chiefly Alberta and Saskatchewan) was injured by a heavy frost on the night of July 24th.

The purpose of instancing these facts is to show that the "average" time of frost is sometimes widely departed from, both in the favorable and unfavorable directions.

This suggests even more forcibly than the short time between frosts, the desirability of (1) growing "safer" crops, and (2) developing a more di. versified agriculture, particularly in the

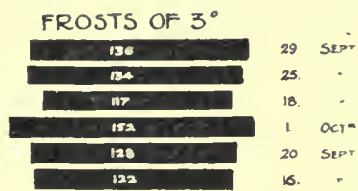

$\begin{array}{lcc}\text { WIKNLPEG } & \text { MAY. } 27 . \\ \text { ESTEVAN. } & \text { JUNE. } 1 . \\ \text { PRUCE ALBERT. } & - & 4 \\ \text { MARL CREEK. MAY } & 12 \\ \text { CALEARY. } & - & 29 \\ \text { IDMONTON. } & - & 30 .\end{array}$

Fig. 14.-Frost-Free Period at Different Points. Above, length of period between spring and fall frosts of three degrees. Below, length of period tetween frosts. Twelve year average.

temperature zones showing the greatest variations from the average.

18. Frost Resistance of Different Crops.-Cereals will withstand heavy spring frosts but not fall frosts. Root (rops and rape will withstand heavy fall frosts but suffer considerably from heavy spring frosts. Corn and potatoes will withstand neither, although potatoes will live through frosts that kill corn. Flax and peas suffer considerably from both spring and fall frosts, while perennial grasses and legumes will withstand very low temperatures at either season.

19. The Average Temperature of the Growing Period. -The average temperatures at representative points for each month in the year are indieated on the diagram, 
and the actual figuress are quoted in the table that follows. These show very favolable temperatures for growth in summer (Pen at far north points such as Fort Simpson. The more rapid fall of autumn temperatures and the lower temperalures in spring, in the northern latitudes, indicate a shorter growing season. By comparing the montlyy rainfall and monthly temperature illustrations it will be seen that the months of highest temperature follow closely the months of greatest rainfall. To this fortunate "aceiclent" of climate is largely due such success as has attended the efforts of the crop grower in the Canadian West.

Table V.-The Average Mean Monthly and Annual Temperatures at Representative Points.*

Station Jan. Feb. Mar. Apr. May Jun. Jul. Aug. Sep. Oct. Nov. Dec. Yr.

$\begin{array}{lrrrrrrrrrrrrr}\text { Calgary } & 12 & 14 & 24 & 40 & \mathbf{4 9} & \mathbf{5 5} & 61 & 58 & \mathbf{5 0} & \mathbf{4 2} & \mathbf{2 6} & 20 & 38 \\ \text { Edmonton } & \mathbf{7} & 9 & 22 & \mathbf{4 1} & 51 & 57 & 61 & 59 & \mathbf{5 0} & \mathbf{4 8} & 29 & 19 & 38 \\ \text { Mledicine Hat } & 11 & \mathbf{1 3} & 27 & \mathbf{4 5} & 55 & 62 & 68 & 67 & 56 & 46 & 27 & 21 & 42 \\ \text { Prince Albert } & 4 & 2 & 12 & 37 & 49 & 57 & 62 & 59 & 49 & 38 & 18 & 5 & 32 \\ \text { Regina } & 4 & 2 & \mathbf{1 4} & 37 & 50 & 59 & 64 & 61 & 51 & 39 & 21 & 8 & 33 \\ \text { Winniper } & 5 & 1 & \mathbf{1 4} & 37 & 52 & 62 & 66 & 63 & 53 & \mathbf{4 0} & 20 & 5 & 34 \\ \text { Dunvegan } & 12 & 2 & 13 & 34 & \mathbf{4 8} & 56 & 60 & 57 & 49 & 35 & 16 & 3 & 29 \\ \text { Ft. Chipewyrn } & 13 & 10 & 5 & 27 & 44 & 56 & 62 & 58 & 46 & 33 & 12 & 1 & 26 \\ \text { Ft. Simpson } & 18 & 16 & 4 & 26 & \mathbf{4 2} & 55 & 59 & 56 & \mathbf{4 5} & 24 & 1 & \mathbf{1 2} & 21\end{array}$

\section{The Total Heat Received During the Period of} Growth.--The total amount of heat received during the growing season may be determined by multiplying the number of days of growth by the difference between the temperature repuired for plant growth and the average daily temperature for the period. The result is spoken of as the "acemmulated temperatures" which is the sum of the "lay degrees" of temperature between the time in

* From Canadian Year Book reporting Dominion Meteorological Service data-Calgary 20 years, Edmonton 25 years, Prince Albert 20) years and Winnipeg 70 years. Data for other places taken from the "Climate of Canada", by Stupart. 
tha spring when plant growth starts and the time in the fall when it stops. Enstead worked this out from the meagre data that were arailable with the results indicated on the map.t In arriving at these results he arbitrarily took the time in the spring

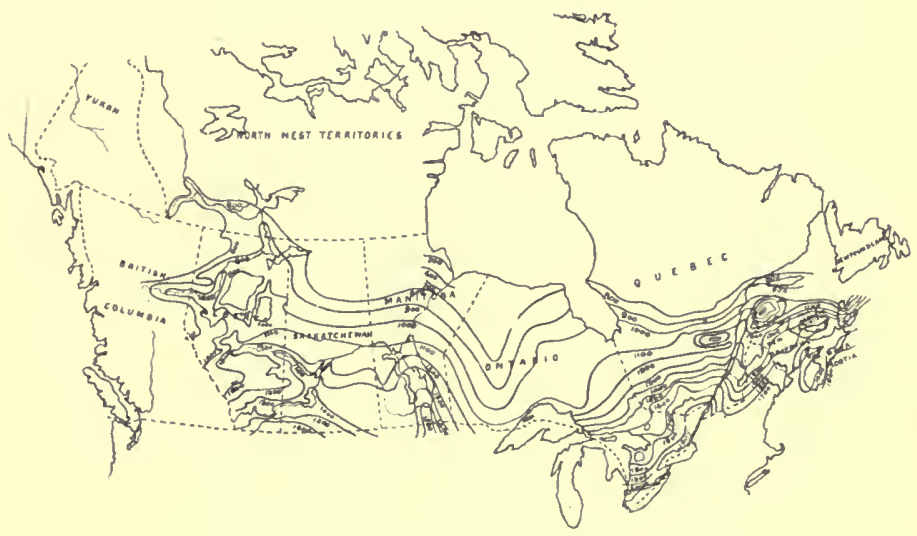

Fig. 15.-Temperature Zones of Canada.

As determined by the accumulated temperatures between time in the spring when growth of cereals starts and time in the fall when it normally ceases. - After Unstead.

when the average daily trmperature rises above $5^{\circ} \mathrm{C}$. or $41^{\circ} \mathrm{F}$. and the time in the fall when it descends to $10^{\circ} \mathrm{C}^{\circ}$. or $\overline{5} 0^{\circ} \mathrm{F}$., as being the time when plant growth starts and stops respectively.

In the repolt of the same investigation he pointed out that at Ottawa, Red Fife would mature with an acemmulated temperature of 13:30 degrees, Ladoga with 1210 degrees and Early Riga with 1030 dogrees. With our longer hours of sunlight here and the very early varieties that are now available the possibility of growt Reported in "lihe Geographical Jomrnal", April and 11 ! 1912. 
ing wheat very far north in Alberta seems promising. How profitable it may be, the average date of the first fall frost and the pereentage of seasons that are free from summer frosts will largely determine.

21. Wind Velocity.-The wind velocity averages higher on the open plains than in the park belt and wooded areas. In some seasons it does serious injury to tender plants and shrubs by eausing the soil to drift. Aceording to Cross* the average velocity ranges in different parts of the West from 5.1 to 13.3 miles per hour, while the average maximum ranges from 30 to 57 miles per hour.

22. The Chinook Wind.-The temperature of the southresterly winds is the highest and that of the northeasterly the lowest. The Chinook, a warm southwest wind, is often responsible in winter for removing the snow eovering very soon after it comes. This is perhaps farorable for the raneher but not so for the crop grower. In summer this wind sometimes does serious injury to erops in southern Alberta and southwestern Saskatehewan, oecasionally as far east as Moose Jaw and Saskatoon. It is reported that it is occasionally felt in milder form as far north as the Peace River Valley and upper Mackenzie basin.

23. Humidity of the Wind.- Little data is availible concerning the humidity of the atmosphere in these winds but experience has shown that the southwest and west ones are very dry while those from other directions are generally more hmmid, especially the east winds.

"In "Climate and Rainfall", by J. F. Cross in "Prairic Provinces of Canada", Sells I,td. 
24. Wind Direction.-Mr. J. F. Cross, ${ }^{*}$ Superintendent of St. John's College Observatory at Winnipeg has this to say on the general subject of winds in the Prairie Provinces:

"The typieal wind of the prairie section is northwest, that of the Chinook (southern Alberta and southwestern Saskatchewan) southwest. Modifications of these arise in several districts owing to local peculiarities, and velocities also vary considerably. . . Generally, however, in Manitoba the direction tends north or south with almost continuous moderate velocity and a number of light gales; in Saskatchewan the westerly type begins to appear, while in northern Alberta the most prevalent wind is due west. In southern Alberta and especially in distriets adjacent to the Rocky Mountains the direction is usually southwest and the veloeity rarely exceeds 30 miles an hour. The force of the air movements on the whole is greater in places of low latitude. Hurricanes are, however, practically non-existent in the Canadian West, the one notable exception being the cyclone which visited Regina during the summer of 1912 and caused considerable damage in the business section of the city."

25. Atmospheric Humidity.-The meteorological data on the atmospheric humidity of the West is very meagre. In brief, it indicates that our atmosphere is very dry, the driest being in the areas of lowest precipitation and highest temperature, viz., southéastern Alberta and southwestern Saskatchewan.

A dry atmosphere inereases evaporation. This is notieeable, chiefly in the "Chinook" region where after

*In "The Prairic Provinces of Canada". 
melting the snows of winter, the warm dry wind sueks up the moisture very rapidly. The dry atmosphere is, however, not always a misfortune. 'T'his is one of the eauses of high quality in wheat and also one of the chief causes of the relatively small damage from rust and other fungous diseases in the dry parts of the West. Carleton," referring to this point, states that " $\Delta$ heavy stand of wheat in humid districts is favorable to rust. Under these conditions it should be noted that the atmospheric humidity is the influeneing faetor. . . . .

"In this distriet (the spring wheat belt of Canada and the United States) beeause of the deep blaek soil and dry, hot summers, there is grown the highest grade of eommon spring wheat in the world execpting the spring wheats of the middle Volga district of Russia, which are very similar."

\section{Long Hours of Sunlight in the Growing Season.-} Light is essential for plant growth. Without it plants cannot manufacture their food. Man eannot eontrol the light except in a negative way by preventing weeds and other obstacles shading useful plants. Two phases of this question are, however, very interesting. 'The first is the length of the day in summer in northern latitudes, and the second the relative lack of clonds in this climate.

The number of possible hours of sunshine daily during June, July and August at various places is indicated on the sunshine map. The long days of summer and the relative lack of cloudiness in Western Canada eneourages rapid growth and makes possible the maturing of crops in much less time than people of southern

*In "Ihe Small Grains", by Carleton. 
climates can imagine. These conditions, together with the favorable monthly distribution of precipitation, are largely responsible for the measure of suecess that has been attained in erop growing in our northern semi-arid climate.

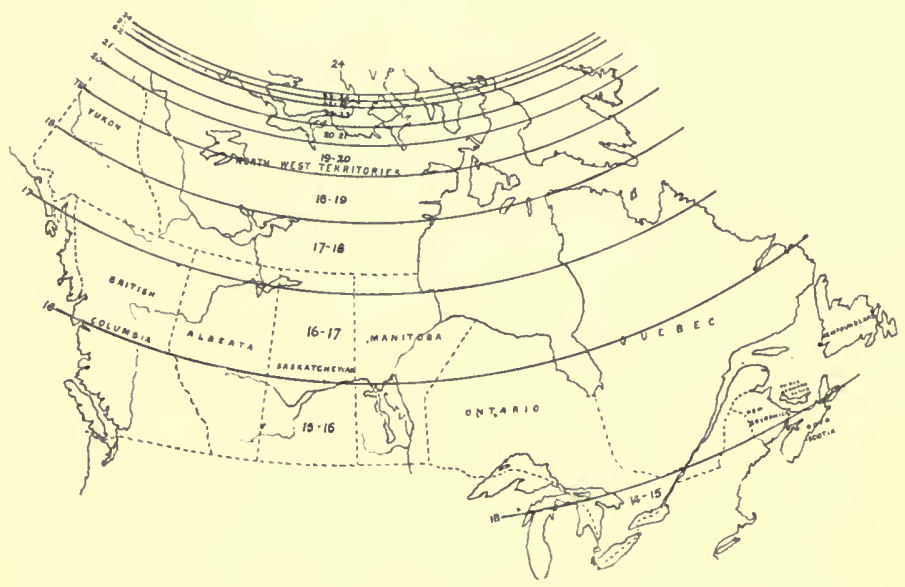

Fig. 16.-Hours of Possible Sunshine Daily in Summer.

26a. The Effect of Latitude and Altitude on Temperature.-Where no other factors interfere the average deerease in temperature is approximately three degrees for every 100 miles one goes in a northerly direction. It is seldom, however, that this ratio is not affected by changes in altitude or relation to forests or large bodies of water.

The lowering of temperature as a result of inerease in elevation averages one degree for every 300 feet. The effect of latitude and altitude is elearly shown by the height of the permanent snow line above sea level. At the north pole this line is at sea level. At the southern 
boundary of Canada it may be seen in the Rocky Mountains at an altitude of 6,000 to 8,000 feet and at the cquator it is found only after reaching the height of 16,000 to 18,000 feet.

26b. The Effects of Forests on Climate.-The effect of forests on climate is to lessen the extremes of precipitation, eviporation, wind veloeity and to some extent the temperature. How much the forests of North-western Canada affect our climate it is difficult to estimate. In the practice of farming its greatest influence is probably found in lessening the wind velocity and thereby the evaporation and danger from soil erosion. This favorable effect is, of eourse, greatest in the wooded areas and least in the prairie and Chinook belts. 


\section{CHAPTER III.}

\section{THE SOIL}

By Roy Hansen, M.S., Professor of Soils, University of Saskatchewan, Saskatoon.

27. The Role of the Soil.-The existenee of mankind is dependent upon three things: the earth, the atmosphere and the sunshine. Of these, only the earth is subjeet to the will of man, to eonserve or destroy aecording to his knowledge or ignorance. And of the earth, it is with the shallow surfaee crust, but a few inches in thickness, whieh we designate as "the soil", that we are most concerned. The soil must support the plant world which in turn supports the animal world, including mankind. Thus the food we eat, the clothes we wear, and the timber that provides us shelter come ultimately from the soil. The soil, therefore, is our greatest resource, the very foundation of life and prosperity.

The growing plant in its endeavor to reprochuce its kind, the chief function of all life, had need of five essentials: (1) a place to take root, that it may support its aerial parts; (2) food, as important to plants as it is to animals; (3) moisture; (4) heat; (5) light.

With the exception of light the soil is eoncerned in eaeh of these essentials. The root system of the plant is 
determined by the texture of the soil. The soil must furnish the mineral plant food elements and nitrogen. It absorbs and retains the rainfall to be given up to the plants as needed. It absorls and transmits heat upon which plant life is dependent. These factors we ean in a large measure control by our farm practices. In order to know the best practices to pursue, it is essential that we know why and how the soil responds to different treatment.

\section{History and Physical Properties.}

28. Origin.-Geologists tell us that the earth was at one time a molten mass cast off with its whirling motion from the sun. Through many centuries this mass slowly cooled, the molten materials forming a crust of solid roek and the vapors eondensing to water to form lakes and oeeans. The rock was broken down to a disintegrated mass by the grinding action of the glaciers and the slower process of weathering. Part of this disintegrated material was carried away and redeposited by the wind or water, becoming again ecmented in stratified form into rock. Part of it remained in place and formed the beginning of the soil, aeenmulating slowly through the ages by Nature's processes.

The forces of disintegration and transportation liave been at work during all time. The power of freezing and thawing in crumbling down rock is familiar to all. The deep erevices in granite rock with the pile of crumbled-off material at the hace tells the story of Nature's work. The effects of water with its driving force as rain, and its dissolving and wearing action in flowing over rock surface are well evidenced in the 
eaverns and caves it euts in stratified sandstone and limestone deposits. The wind picking up particles of sand, grinds and wears the rocks to powder. The atmosphere with its moisture and gases aids in this proeess of solution and disintegration.

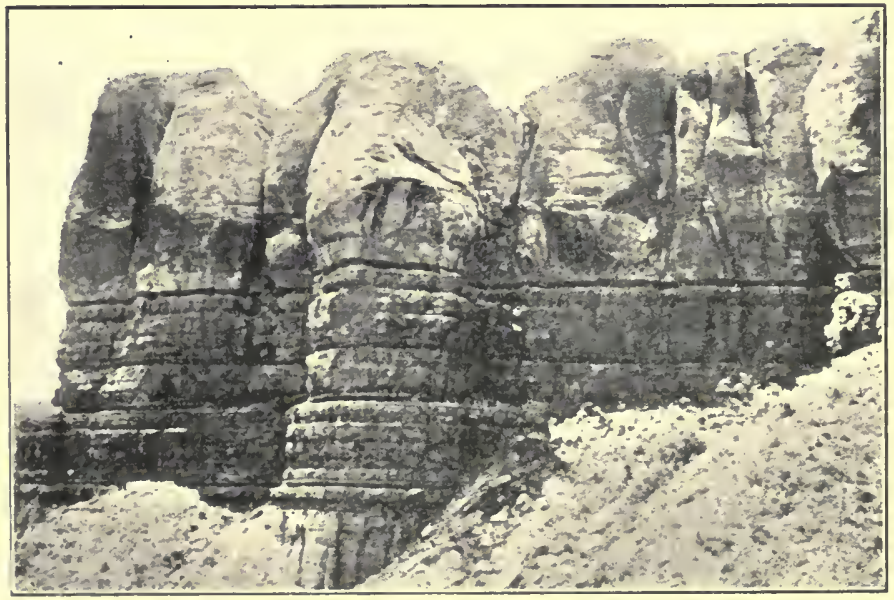

Fig. 17.-Rock Weathering.

A step in soil formation.-Chamberlain \& Salisbury, conrtesy Henry Holt $\&$ Co.

With the coming of life upon earth, first the baeteria perhaps and then higher plants and animal life, new forees of disintegration came into play. The baeteria were able to feed upon the rock materials, building living tissue from the solid minerals which they dissolved and assimilated. Plants and then animals took part in the proeess, exerting in part meehanical or physical foree, in part chemical force and in part biological foree. With the deeay of vegetable and animal matter organie aeids were liberated and these assisted in the process. 
Thus the process went on, the rock materials supporting plant life, and the latter contributing further to soil building.

The ultimate outcome was the soil, made up as we now know it, of stones, gravel, sand, silt, clay and organic matter. These then were the final products, though we must not think of the proeess as being finished. Nature is constantly at work levelling mountains, disintegrating rocks, and transporting and depositing the materials without heed to the desires of man, indeed often contrary to his wishes.

29. Soil Classification.-According to the manner of formation and deposition and the ageneies that played the leading part, soils are elassified as indicated in the following outline-

(1) Sedentary, formed in place:

(a) Residual, formed in place from disintegration of rocks.

(b) Cumulose, formed in place by the partial deeay and aceumulation of vegetable matter.

(2) Transported Soils :

(a) Glaeial soils, deposited by glaciers.

(b) Loessial soils, deposited by the wind.

(c) Alluvial soils, deposited by the action of water.

Sedentary Soils.- Is the name indicates, these are formed in place, no appreciable transportation from the location of the original rock upon which they rest having taken place. Sedentary soils are further subdivided into (1) residual, soils formed in place from the disintegration of roeks; and (') eumulose, soils formed in place by the partial decay and aeeumulation of vegetable mat- 
ter (plant remains). Limestone soils, produetive soils covering extensive areas in the southern and eastern states of the United States, are examples of residual soils. Frequently the limestone has completely leached away, the soil eonsisting entirely of the impurities of the original limestone and plant remains. Cumulose soils are illustrated by mucks and peats which have been formed under peeuliar conditions, (i. e. poor drainage as in swamp and bog land) allowing the partial decay and aecumulation of plant remains, the growth of moss, swamp grass, ete., on top exceeding tha rate of decomposition of the old remains, thus resulting in the deposition of a soil consisting largely of organic matter.

Transported Soi's.-.These are likewise formed by rock distintegration, but the materials are ramoved from their original resting places. Chief among the agencies of transportation are the wind, the glaciers, and water.

Material picked up and deposited by the wind is termed loess. Loessial soils occupy a large area in the prairies of the United States, and in depth they vary from a few inches to perhaps 200 feet.

The material brought down and deposited by the glaciers is ealled glacial till or boulder clay. Soils so formed are more varied in elaracter, eoutaining frequently rounded stones and gravel along with much silt and fine sand, the result of the grinding artion of these huge ice sheets, and fregnently lnige boulder's left upon the open prairies.

Soils deposited through the ageney of water, such as the deltas of rivers, old lake bottoms, ete., are termed alluvial soils, and these generally rank among our most fertile soils. 'The delta of the Nile and the Red River' 
Valley of the North are typical examples, the latter being at one time the beel of the old Lake Agassiz.

30. Soil Types.-Soils are further divided into types depending upon the content of the various soil materials. Thus we liave gravels, sands, silts, clays, gravelly loam, sandy loam, silt loam, clay loam, muek, peat and loam. By a loam is meant a soil having a good balance of the various constituents, that is, not enough clay to render it plastic, not enough sand to make it too loose and open, and with a suffieient supply of organic

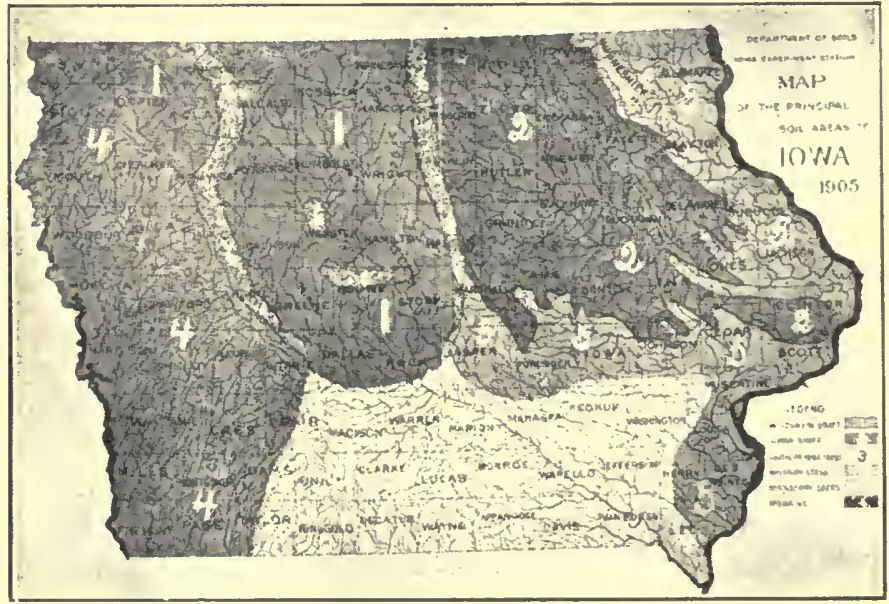

Fig. 18.-Soil Surface Map of Iowa.

The soils in eacl county in most of the States are being mapped and classified and the local agricultural conditions studied in order that intelli. gent direction may be offered farmers for increasing production. The problems of Western ('anada need such a systematic study.-Courtesy of the Iowa Experiment Station.

matter to give a good friable texture. 'The pereentage of various soil materials determines the physical character of the soil, i. e. the texture, the ease of cultivation, the 
temperature, the water-holding eapaeity and the porosity (air-space).

31. Physical Properties of Soils.-The above elassifieation depends upon the size of the soil partieles and upon the organic matter content, these factors determining its physieal properties. Sandy soils have large particles predominating and this results in their looseness and openness, their non-adhesiveness. Water draius readily through such soils, and less is retained for crops. Air cireulates more freely, the pore spaces are larger and because of this, and the fact that they hold less water, sandy soils are "warmer", "earlier", and therefore best adapted in the humid seetions to truek farming and early vegetable gardening.

Clays, on the other hand, are plastie, difficult to work when wet. This is due mainly to the extremely small soil particles and in part to the plastic nature of the material, kaolin or fire-elay, which makes up a considerable part of sueh soils. Clays retain more moisture, the particles being smaller and henee more numerous per given volume; the water film surrounding the particles is more extensive in area, lience the ability to hold more water. Air eireulates less freely. The total air spaee is greater in elays (porosity is inversely proportional to the size of the particles), but the movement of air finds greater resistance. $\Lambda$ further fact about clays is that though they retain more moisture, they give it up with less ease to plants than do sands. Plants will wilt in a clay soil, whereas in a sand of equal total moisture content, they would show no signs of lack of moisture. Thus in general clay soils are "colder", "later", more retentive of moisture and more difficult to work. 
Humus, the aceumulated residue of the decomposition of plant remains, plays an important role in the physical properties of soils. Being somewhat plastic and spongy in nature, it binds the sand partieles together, giving such soils greater adhesiveness and henee better tilth. In elay it binds the small particles together into larger aggregates, thereby lessening the plasticity and rendering them easier to work. Due to its porous nature it inereases the water-holding eapaeity, facilitating the absorption and retention of water. It increases the porc-space, allowing the air to circulate more freely in the heavier types of soil, thereby inereasing the warmth, and making the soil "earlier". The importanee of keeping up the humus eontent from the standpoint of the physieal properties of the soil is, therefore, important; the role from the ehemieal and biological standpoints will be discussed later.

The eapillary rise of water in soils is eontrolled by the size and eompaetness of the soil particles. Although water rises more rapidly in a sandy soil because of less resistanee, the total height to whieh it will rise and the force exerted in the upward rise are greater in the heavier types. Soil-packing, therefore, results in better capillary contact besides assisting in the decay of vegetable matter by the eloser eontact with moisture.

32. Dry-Farming and Soil Physics._Dry-farming puts into practice our knowledge eoneerning the physieal properties of soil. For example we plow for summerfallow before the last of the heavy summer rains eome in order to render the soil more open and retentive of moisture. The use of the soil packer on fall and spring plowing is to lessen the air space in the soil and to aid in bringing the moisture up to where the seed is to 
be planted; and the object of surface cultivation, aside from controlling weeds, is to provide a satisfactory seed bed containing the right amounts of moisture, heat and air for germination and growth. Surface cultivation also provides a mulch which lessens to some extent the cracking of the soil and thereby checks evaporation.

\section{Soll Fertility or Chemistry.}

33. The Food of Plants.-Food is as important a consideration to plants as it is to animals. Animals require for food vegetable matter, such as starch, sugar, fat, protein, ete., the highly organized, complex materials built up by plant life. While animals frequently eat animal flesh, plant life is the primary source of food. The nutrition of plants, however, is different. They require as food the simple, inorganic materials derived from the solution of rock materials or from the decay of plant or animal remains. This food is taken up in water solution, and by the plant is built up into tissue, i.e. sugar, starch, cellulose, protein, the things for which we prize plants as food for human or stock consumption.

34. The Essential Elements.--The earth's crust is composed of about 80 elements in varying amounts and combinations or compounds. Of the 80 elements, 40 are more or less common, and 15 , because of their wide occurrence in plants, soils, water and in the atmosphere, are important in soil fertility. Of these 15 elements, 10 are essential for the growth of plants; deprived of any of them the plant would suceumb, or would, at least, be unable to reproduce its kind. These elements which are 
divided into three groups for the purposes of our diseussion, are as follows :-

$\begin{array}{lll}\text { Group 1. } & \text { Group 2. } & \text { Group } 3 . \\ \text { Carbon } & \text { Calciun } & \text { Nitrogen } \\ \text { Hydrogen } & \text { Magnesium } & \text { Phosphorus } \\ \text { Oxygen } & \text { Iron } & \text { Potassium } \\ & \text { Sulphur } & \end{array}$

Carbon, Hydrogen, Oxygen.-Carbon is derived from the carbon-dioxide of the air. By means of their "breathing pores" the leaves of plants take in this gas and in some way combine it with water to make sugars. Oxygen is likewise derived from the air, both as earbondioxide and free oxygen gas, and from water, of which it is a constituent part. Hydrogen is derived from water. These three elements, earbon, hydrogen and oxygen make up from 90 to $95 \%$ of mature plants and this fact, together with the fact already noted that they are derived from the atmosphere and water, has led to the error of minimizing the importance of the other seven essential elements.

Calcium, Magnesium, Iron, Sulphur.-Of the remaining seven essential elements, four, ealcium, magnesium, iron and sulphur, though necessary to plants, oceur in relatively large amounts in the soil in proportion to the amounts required by plants. Therefore they do not concern us, sinee they are not likely to limit our crop yield. The soil is the source of these elements for plants (some sulphur comes down with the rain).

Nitrogen, Phorphorus, Potassium.-The elements of this group, nitrogen, phosphorus and potassium, are, for common farm erops, derived from the soil. (Legumes can take nitrogen from the air, as will be discussed later). Potassium oceurs in liberal amounts in most 
soils; in some types, particularly muck and peat, it is frequently lacking and must therefore be supplied if maximum yields are to be obtained. In normal soil, however, it is seldom lacking. Nitrogen and phosphorus on the other hand are very frequently deficient, and they are, therefore, among the most common world-vide soil problems.

\section{The Essential Elements in Saskatchewan Soils.-} In the table that follows is given the average content in Saskatchewan soils of five essential elements. The figures reported represent the averages of the a n a $\mathrm{yses}$ made by the Department of Chemistry of the University of S askatehewan, of 16 samples of soil, 8 being virgin prairic soils. The plowed acre taken to a depth of $6,2 / 3$ inches

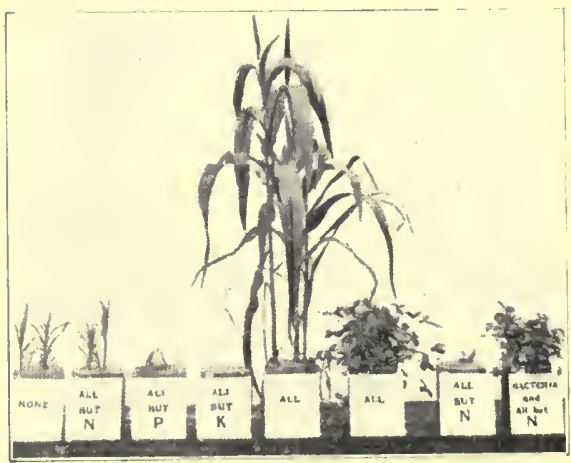

Fig. 19.-Pot Cultures.

Showing the effect of the presence and ab. sence of plant foods: N. nitrogen; P. phosphorus; l. potassium. Note that inoculated clover grows normally without commercial nitrogen, the plants securing their supply from the air. Without inoculation or commercial nitrogen the plants fail.-Courtesy Illinois Agricultural Experimental Station.

is taken to weigh

$2,000,000$ pounds, the analyses being computed on this basis.

The second column of figures indicates the amounts of these elements required to prodnee 30 bushels of wheat including both grain and straw. Knowing the soil con- 
tent and the amount required for a 30-bushel crop, we can calculate the numbers of 30 -bushel crops that are theoretically possible (column 3).

'Тав..E VI.- "Supply and Demand" of Hesential Elements in $A v-$ erage Saskatchewan Soil.

\begin{tabular}{l|c|c|c|c}
\hline $\begin{array}{c}\text { Essential } \\
\text { Elements }\end{array}$ & $\begin{array}{c}\text { Pounds in 2,000,000 } \\
\text { of surface soil from } \\
\text { an average of } 16 \text { soils }\end{array}$ & $\begin{array}{c}\text { Pounds in } 30 \text { bus. } \\
\text { of wheat includ } \\
\text { ing straw }\end{array}$ & $\begin{array}{c}\text { No. of } 30 \text { bus. } \\
\text { crops of wheat } \\
\text { possible }\end{array}$ \\
\cline { 2 - 3 } Nitrogen & 8604 & 57.6 & 150 \\
Pliosphorus & 1830 & 9.6 & 191 \\
Potassium & 34925 & 34.8 & 1004 \\
Calcium & 31074 & 6.3 & 4.932 \\
Magnesium & 11738 & 4.8 & 2445 \\
\hline
\end{tabular}

While such an average analysis of soils does not represent the true average for the province and while 16 samples are not enough upon which to base final judgment, the results do have instruetive value. It is apparent that nitrogen and phosphorus, of the essential clements, will first limit erop yields. Undoubtedly the deficiencies are already felt in the poorer, longer-cropped soils. This method of computation is subject to several further qualifications however.

First, the nitrogen supply is subject to additions and deductions other than eropping (exelusive also of fertilization and green manuring). Certain free-living acrobie bacteria (Azotabaeter) living in the soil have the power of extraeting nitrogen from the air; certain amounts of nitrogen are brought down in the rain, chiefly as ammonia and nitrie acid. On the other hand certain bacteria may cause the loss of soil nitrogen into the air (denitrifieation) and what is most important, great losses of soil nitrogen oceur through surface erosion, and through leaching. 'The latter is relatively 
more important in humid regions. But in general even under semi-arid conditions the losses from all sourees other than eropping greatly exeed the gains. Thus 150 erops of thirty bushels eaeh ( 4,500 bus.) is by far too liberal an estimate from the nitrogen standpoint.

Second, with phosphorus, and this applies equally to nitrogen, even under otherwise ideal conditions, we could not eontinue to remove 30 -bushel erops of wheat sueeessively until the plosphorus was exhausted. Under humid eonditions phosphorus becomes a serious limiting factor when the supply is below 1,000 pounds. The yield is determined by the total supply of plant food, and, as will be diseussed later, its "availability". In general the yields will become deereasingly smaller as the phosphorus or nitrogen (or both) is exhausted.

36. Average Saskatchewan Soil vs. Other Soils.-In the following table the "average" Saskatehewan soil is eompared with some well known fertile soils:

TABLE VII.-Average Saskatchewan Soil versus Other Soils in pounds per acre 6 2-3 inches deep-approximately $2,000,000$ pounds.

\begin{tabular}{|c|c|c|c|}
\hline Soil . & Nitrogen & $\begin{array}{l}\text { Phos- } \\
\text { phorus }\end{array}$ & $\begin{array}{c}\text { Potas- } \\
\text { sium }\end{array}$ \\
\hline Average Saskatchewan Soil ..... & 8604 & 1830 & 34925 \\
\hline $\begin{array}{l}\text { Rich, well-balanced normal land is } \\
\text { the Corn Belt } \ldots \ldots \ldots \ldots \ldots \ldots \ldots\end{array}$ & 8000 & 2000 & 35000 \\
\hline $\begin{array}{c}\text { Average prairic soil of the Red } \\
\text { River Valley in Northwestern }\end{array}$ & & & \\
\hline $\begin{array}{l}\text { Minnesota } \\
\text { Fargo black clay soil (North Da- } \\
\text { kota) representative of a large } \\
\text { part of the lRed River Valley. }\end{array}$ & 8200 & 3340 & 45100 \\
\hline $\begin{array}{l}\text { Old wheat landt } \ldots \ldots \ldots \ldots \ldots \\
\text { Red River Valley virgin sod } \ldots \ldots\end{array}$ & $\begin{array}{r}8300 \\
14000\end{array}$ & $\begin{array}{l}1518 \\
1949\end{array}$ & \\
\hline
\end{tabular}

*Hopkins' "Soil Fertility and Permanent Agriculture".

† Doneghue, North Dakota $\Lambda$ gricultural Experimental Station Bulletin 126. 
From this table it would appear that our average soil compares very favorably with some of the well known fertile soils. But again it should be pointed out that this "average" soil does not fairly represent the province; undoubtedly some of our extensive types, as the sandy loams for example, do not measure up to this standard. Furthermore, even on the fertile corn belt land, soil enrichment has been found both practical and profitable.

(See table XIV.).

37. Organic Matter and Soil Fertility-Organie matter is supplied to the soil in general farm practice in the following ways:--

1. Crop residues;

2. Green manuring;

3. Pasturing;

4. Applying farm manure.

By crop residues are meant the stubble of cereals, straws, corn stalks, ete. In the corn belt the corn stalks in common practice are broken over, disked and plowed under, and the spreading on the land and plowing under of straw is not uncommon. While these practices may not be possible here, as much organie matter from these sources should be returned as is practicable, either by feeding and returning as manure or bedding down stock, and thus incorporating the straw with the manure. The burning ol' straw piles represents not only a great waste of organic matter and nitrogen, but of other essential elements as well. This is indicated in table VIII, 
TABLE VIII.-Fertility Lost by Burning Strazo.

\begin{tabular}{|c|c|c|c|}
\hline $\begin{array}{l}\text { Essentirl } \\
\text { Elements }\end{array}$ & $\begin{array}{c}\text { Pounds in } 1 \text { ton } \\
\text { wheat straw }\end{array}$ & $\begin{array}{l}\text { Pounds in } 1 \text { bu. } \\
\text { wheat, grain only }\end{array}$ & $\begin{array}{l}\text { Maximum bushels } \\
\text { wheat possible } \\
\text { from } 1 \text { ton straw }\end{array}$ \\
\hline Nitrogen & 10.0 & 1.4 & 7.1 \\
\hline Phosphorus & 1.6 & .24 & 6.7 \\
\hline Potassium & 18.0 & .26 & 69.2 \\
\hline
\end{tabular}

Thus, if we assume that the fertility elements lost by burning the straw could be applied to the production of wheat, we find that in each ton the nitrogen would be sufficient for 7.1 bushels of wheat, the phosphorus for 6.7 bushels, and the potassium for 69.2 bushels. These losses, together with the loss of other benefits of organic matter, are the results of burning the straw. Where straw or manure is spread on the land and then burned over only the nitrogen and organic matter are lost. Phosphorus, potassium and other mineral elements are not destroyed by buming. 'The ashes are valuable as fertilizer if spread evenly over the land.

Green manuring is the practice of growing crops for the express purpose of plowing them under to improve the soil. In the older countries legumes are most commonly used, though buckwheat and rye, the latter used as a cover crop, are widely used. Since this country will never be thickly populated with stock and sinee the depletion of organic matter in the soils is allearly becoming apparent, green manuring must, of necessity, come into common practice, if the organic matter in our soils is to be maintained.

Pasturing, from the standpoint of soil frotility, is the most economical method of retmining manme to the land. The expense of hauling and spreating is saved, and the losses by fermentation (fire-fanging) as ocent in the manure pile in the farmyard, are avoided. 
Sprealing manme is a time-honored custom, and in most communities the benefits are fully appreeiated. Table IX. brings out the fertility value of manure from the standpoint of its content of the essential elements. The figures are computed on the basis of average barnyard manure.

'Table IX.-Fertility Value of Barnyard Manure."

\begin{tabular}{l|c|c|c|c|c}
\hline $\begin{array}{c}\text { Essential } \\
\text { Elements }\end{array}$ & $\begin{array}{c}\text { Pounds in 1 Pounds in } \\
\text { ton average one bushel } \\
\text { barnyard } \\
\text { wheat, } \\
\text { manure }\end{array}$ & $\begin{array}{c}\text { Pounds in } 1 \\
\text { grain only }\end{array}$ & $\begin{array}{c}\text { wheat, } \\
\text { grain and } \\
\text { straw }\end{array}$ & $\begin{array}{c}\text { Possible } \\
\text { bu. wheat, } \\
\text { grain only }\end{array}$ & $\begin{array}{c}\text { Possible } \\
\text { bu. wheat, } \\
\text { grain and } \\
\text { straw }\end{array}$ \\
\hline Nitrogen & 10.0 & 1.4 & 1.92 & 7.1 & 5.2 \\
Phosphorus & 3.0 & .24 & .32 & 12.5 & 9.4 \\
Potassium & 8.0 & .26 & 1.16 & 30.8 & 6.9 \\
\hline
\end{tabular}

Thus one ton of average barnyard manure contains as much nitrogen as 7.1 bushels of wheat, as much phosphorus as 12.5 bushels, and as mueh potassium as 30.8 bushels. If we assume no losses, but that the fertility elements contained in a ton of manure go to make up grain and straw, the nitrogen would be sufficient for 5.2 bushels, the phosphorus for 9.4 bushels and the potassium for 6.9 bushels.

In live stock farming the organic matter reeovered in the mamme represents less than one-half of that fed. Further loss oecurs in the barnyard, due to fermentafion through the action of bacteria, and through leaching. In this commection Hopkins' "Soil Fertility and Permanent Agriculture" says: "As an average in livestock farming, the animals retain about one-fourth of the nitrogen and phosphorus and destroy two-thirds of the organic matter of the food consumed, and large loss is likely to or'ul in the manure produced, especially in nitrogen and organic matter, a loss in one half of these

*Figures from Hopkins" "Soil Fertility and Permanent Agriculture," 
constituents being easily possible during three or four months, in part from fermentation, which may oceur even under cover, and in part from leaching where manure is exposed to the weather or where little or no absorbent bedding is used."

Coneerning manure the North Dakota Experiment Station* finds that, "approximately one-half of the fertilizing value of manure is lost in rotting, so that it probably requires 2 tons of fresh manure to make 1 ton of rotted manure. Considering the cost of extra handling of rotted manure it would be more profitable to haul the manure direetly from the barn to the field. It can be applied to best advantage to pasture in the rotation or plowed under for corn".

38. Functions of Organic Matter.-Organic matter returned to the soil functions in several ways:

1. By improving the physical tilth by increasing the humus eontent as already discussed (i.e. increases the water-holding eapaeity; inereases the pore spaec, henee the "warmth" and "earliness"; renders elays easier to work; gives better adhesiveness to sands, etc.).

2. By supplying the essential elements it contains.

3. By assisting in dissolving the insoluble plant food elements through the action of the acids produced in the decay of the organie matter.

The first two items have already been discussed, the third will be taken up under the action of bacteria in the soil.

39. Losses of Organic Matter in the Soil.-That the present system of farming which makes no adequate provision for the return of organic matter is rapilly de-

* Doneghu:, North Dakota Agricultural Experimental Station Bulletin 126. 
pleting the humus and the nitrogen content has been shown by Shutt, Dominion Chemist, from the following figures* :

TABLE X.-Nitrogen-content of Virgin and Cultivated Soils, Indian IIead, Saskatcherwan.

\begin{tabular}{|c|c|c|c|c|}
\hline & \multicolumn{2}{|c|}{ To a depth of 4 inches } & \multicolumn{2}{|c|}{ To a depth of 8 inches } \\
\hline & Per cent. & Lbs per acre & Per cent. & Lbs per acre \\
\hline $\begin{array}{l}\text { Virgin Soil } \\
\text { Cultivated Soil }\end{array}$ & $\begin{array}{l}.409 \\
.259\end{array}$ & $\begin{array}{l}3,824 \\
2,421\end{array}$ & $\begin{array}{l}.371 \\
.254 \\
\end{array}$ & $\begin{array}{l}6,936 \\
4,750\end{array}$ \\
\hline $\begin{array}{l}\text { Difference or loss duc } \\
\text { to removal in crops } \\
\text { and to cultural } \\
\text { methods. }\end{array}$ & .150 & 1,403 & .117 & 2,186 \\
\hline
\end{tabular}

Doneghue of the North Dakota Experiment Station arrived at similar conclusions with the fertile Red River Valley soil, under a system of continuous wheat-growing, as indicated in table XI.

TABLE XI.-Composition of Old Wheat Soil in Comparison with Virgin Sod.†

Surface Soil, 0-7 inches

Total Nitrogen Total Phosphorus pounds per acre, pounds per acre

Virgin sod

Old wheat land

Losses due to removal in crops and to culturai methods.

5,700

1,949

1,518

Doneghue concludes that, "The black clay soil of the Red River Valley has deteriorated in fertility and cropprodueing capacity under a continuous system of single cropping with wheat. Such land ou the Experiment Station contains approximately one-fourth to one-third

* Western Prairie Soils.

† From North Dakota Experimental Station Bulletin 126. 
less nitrogen and one-fifth less phosphorus than virgin soil of the same type on this farm. The yield during the last eight years of the experiment has been 28 per cent. less than during the first eight years of the 24-year period."

In Saskatchewan six different soils which had been under cultivation for a number of years were compared to six virgin soils of the same type which adjoined or surrounded the eropped land. This gives six comparisons of eropped and virgin land, showing the effect of the present system of farming under actual field conditions. The analyses reported were made by the Department of Chemistry of the University of Saskatelewan.

TABt.E XII.-Losses in Plant-food elements in Saskatchervan Soils through Present Methods of Soil Management. Pounds per 2,000,000 (0-6 2-3 inches.)

\begin{tabular}{|c|c|c|c|c|}
\hline \multirow[b]{2}{*}{ Locality } & \multicolumn{2}{|c|}{ Nitrogen } & \multicolumn{2}{|c|}{ Phosphorus } \\
\hline & $\begin{array}{l}\text { Lbs.per } \\
2,000,000\end{array}$ & Loss & $\begin{array}{l}\text { Lbs. per } \\
2,000,000\end{array}$ & Loss \\
\hline $\begin{array}{ll}\text { Melfort, } & \begin{array}{l}\text { virgin } \\
\text { cropped } 29 \text { years }\end{array}\end{array}$ & $\begin{array}{l}12300 \\
11480\end{array}$ & 820 & $\begin{array}{l}1720 \\
1520\end{array}$ & 200 \\
\hline Kinistino, virgin & 14420 & & 2300 & \\
\hline $\begin{array}{cl}\text { "“" } & \begin{array}{l}\text { cropped } 34 \text { ye } \\
\text { Rosthern, virgin }\end{array}\end{array}$ & $\begin{array}{r}11500 \\
8800\end{array}$ & 2920 & $\begin{array}{l}2140 \\
2880\end{array}$ & 160 \\
\hline " cropped & $\begin{array}{r}6360 \\
10800\end{array}$ & 2440 & 1620 & 1260 \\
\hline "“ cropped 31 years & $\begin{array}{r}10000 \\
9740\end{array}$ & 1060 & 1880 & 340 \\
\hline Regina, virgin & $\begin{array}{l}6800 \\
5980\end{array}$ & 820 & $\begin{array}{l}1740 \\
1440\end{array}$ & 300 \\
\hline Indian “ Hoad, virgin & $\begin{array}{l}9100 \\
3960\end{array}$ & 5140 & $\begin{array}{l}2820 \\
1680\end{array}$ & 1140 \\
\hline $\begin{array}{l}\text { Average loss through cultivation } \\
\text { six soils }\end{array}$ & & 2200 & & 567 \\
\hline
\end{tabular}

Humus, the residnal material from the decomposition of organic matter in the soil, is rapidly dissipated when humus-forming materials (organic matter) are not supplied. Nitrogen in the soil is contained in the organic matter and by decomposition of the latter is made avail- 
able to plants. Thus the loss of 2,200 pounds of nitrogen, the average of the six comparisons, represents the dissipation of a great amount of organic matter. The practice of summerfallowing especially hastens the decomposition and dissipation of organic matter, and if the practice is a neecssary evil, provision must at least be made in the future for supplying the humus-forming materials. The actual amount of nitrogen removed by crops is probably less than one-third of the figure given, the other two-thirds, 1,467 lbs, being lost mainly through surface washing, soil blowing or drifting, and perhaps leaching.

The phosphorus loss, 567 pounds, is far greater than could be explained by removal in crops. Phosphorus being contained principally in insoluble form in the soil, is not lost by leaching. Surface-washing and perhaps soil-blowing or "drifting" are largely responsible for the losses not accounted for in the crops.

The figures in table XII. are not to be taken at their absolute value, however. We cannot be certain that a sample of soil from cropped land had at one time the same composition as a sample of virgin land adjoining. However, when repeated eomparisons show the same result, we have a good "indication" of the results of our farm practices. That a tremendous loss in organic matter does oceur is a matter of common observation, and the bad effects are plainly evident in working the land.

40. The Rothamsted Experiments on Soil-Fertility.The best information on the value of soil treatment as opposed to no treatment in good systems of erop rotation is from the Rothamsted Experiment Station near London, England. Two rotations are compared as follows: 
Rotation I.

Turnips

Barley
Rotation II.

Turnips

Barley

Clover (or beans where clover failed) Fallow

Wheat
Wheat

The first is termed the legume rotation, the second the fallow rotation. Both rotations are arranged so that complete fertilization can be compared to no treatment. The eomplete fertilization consists of the addition of essential plant food elements in the form of common commereial fertilizers. Nitrogen, phosphorus, potassium, magnesium, sodium and sulphur are included, in the form of ammonium sulphate, acid phosphate, potas sium chloride, etc. The fertilizers are applied once in four years (for the turnip crop). The experiment has been earried on for sixty years, the results appearing in table XIII.

Table XIII.-Rothamsted Experiments, Agdell Field.

\begin{tabular}{|c|c|c|c|c|}
\hline & \multicolumn{2}{|c|}{ Unfertilized } & \multicolumn{2}{|c|}{$\begin{array}{c}\text { Fertilized with } \\
\text { Minerals and Nitrogen }\end{array}$} \\
\hline 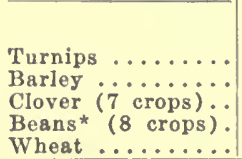 & $\begin{array}{l}\text { Legume } \\
\text { Rotation } \\
2651 \mathrm{lbs} \text {. } \\
24.7 \mathrm{bu} . \\
2094 \mathrm{lbs} \text {. } \\
13.0 \mathrm{bu} . \\
25.0 \mathrm{bu} .\end{array}$ & 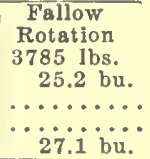 & $\begin{array}{l}\text { Legume } \\
\text { Rotation } \\
34,906 \mathrm{bs} \text { b. } \\
38.9 \mathrm{bu} . \\
5,379 \mathrm{bs} . \\
\mathbf{2 2 . 3} \mathrm{bu} . \\
34.6 \mathrm{bu} .\end{array}$ & $\begin{array}{c}\text { Fallow } \\
\text { Rotation } \\
36,695 \mathrm{lbs} . \\
36.2 \mathrm{bu} . \\
\ldots \ldots \ldots \\
31.8 \mathrm{bu} .\end{array}$ \\
\hline
\end{tabular}

This is perhaps the world's best evidenee on the food requirements of plants. On the unfertilized fields the crop yields steadily decreased. On the fertilized fields the yields have been maintained at a high average, the turnips averaging during the last 20 years of the 60 -

* Beans grcwn when clover failed. 
year period more than double what the unfertilized land was eapable of at the beginning. The rotations alone, therefore, would not maintain yields without fertilization. Plants as well as animals require food.

41. Illinois Experiment.-The Illinois Agricultural Experiment Station is eondueting an experiment on the typical brown silt loam prairie land of the Corn Belt. Five fields are under cultivation, "wheat, eorn, oats and clover being rotated for five years on four fields, while alfalfa oceupies the fifth field, whieh is then brought under the four-erop system to make place for alfalfa on one of the other fields for another five-year period, and so on*". Sixteen years' results have been published $\dagger$, the averages appearing in table XIV.

TABLE XIV.-Illinois Experiment: Urbana Field. Brozen silt loam prairie: Early Wisconsin Glaciation.

\begin{tabular}{|c|c|c|c|c|c|c|c|}
\hline \multirow{4}{*}{$\begin{array}{l}\text { Serial } \\
\text { plot } \\
\text { No. }\end{array}$} & \multirow[t]{4}{*}{$\begin{array}{l}\text { Soil treatmont } \\
\text { applied }\end{array}$} & \multicolumn{6}{|c|}{$\begin{array}{l}\text { Average Annual Yields-bushels or (tons) } \\
\text { per acre }\end{array}$} \\
\hline & & Corn & Oats & Wheat & Clover & Soy- & [Al- \\
\hline & & 19 & & & 8 & Beans & $\left\{\begin{array}{c}\text { falfa } \\
6\end{array}\right.$ \\
\hline & & crops & crops & crops & crops & crops & crops \\
\hline 1. & None & 56.6 & 47.6 & 21.9 & $(2.10)$ & $(1.60)$ & $(2.33)$ \\
\hline 2. & Residues & 56.8 & 49.1 & 26.3 & 1.34 & 21.3 & (2.14) \\
\hline 3. & Manure & 64.6 & 54.0 & 24.6 & $(2.31)$ & $(1.68)$ & $(2.10)$ \\
\hline 4. & Residues, $\lim \theta$ & 59.8 & 50.9 & 28.3 & 1.60 & 20.7 & $(2.32)$ \\
\hline 5. & Manure, Lime & 66.8 & 56.2 & 30.6 & $(2.74)$ & $(1.72)$ & $(2.76)$ \\
\hline 6. & Residue, lime, phosp. & 75.4 & 64.2 & 42.5 & 2.16 & 22.6 & $(3.56)$ \\
\hline 7. & Manare, lime, phosp. & 72.6 & 63.5 & 40.1 & $(3.62)$ & $|(1.92)|$ & $(3.5$ \\
\hline
\end{tabular}

1. Figures in parenthesis represent tons of hay.

2. Soy-beans planted when elover failed.

By comparing plots 2, 4, and 6 with 3, 5, and 7 respectively, we have direet comparisous between two

"Hopkins, et al, Soil Report No. 18 Champaign County Soils.

† Hopkins, et al, Illinois $\Lambda$ grieultural Experiment Station Bulletin 219. Illinois crop yields from Soil Experiment Fields. 
systems of farming,- - grain farming and live-stoek farming. Hopkins* explains this method as follows:

"Under the live stock system of management the nitrogen and organie matter of the soil are maintained by apply. ing as much manure as can

Corn be made from the produce grown upon the land. On this basis no more manure is applied to a plot than can be made from the produce of that plot. For every

ton of produce grown, an equivalent amount of average farm manure is returned during the rotation. Under a good system of live stock farming it has been found that about one ton of average manure can be made from one ton of feed and bedding. A large amount of the grain produced is fed, in the live stoek system, the legumes harvested as hay, and the hay, straw and stover used for feeding and bedding purposes."

* Ibid. 
"In the grain system of farming, no manure is applied to the land. The nitrogen and organic matter of

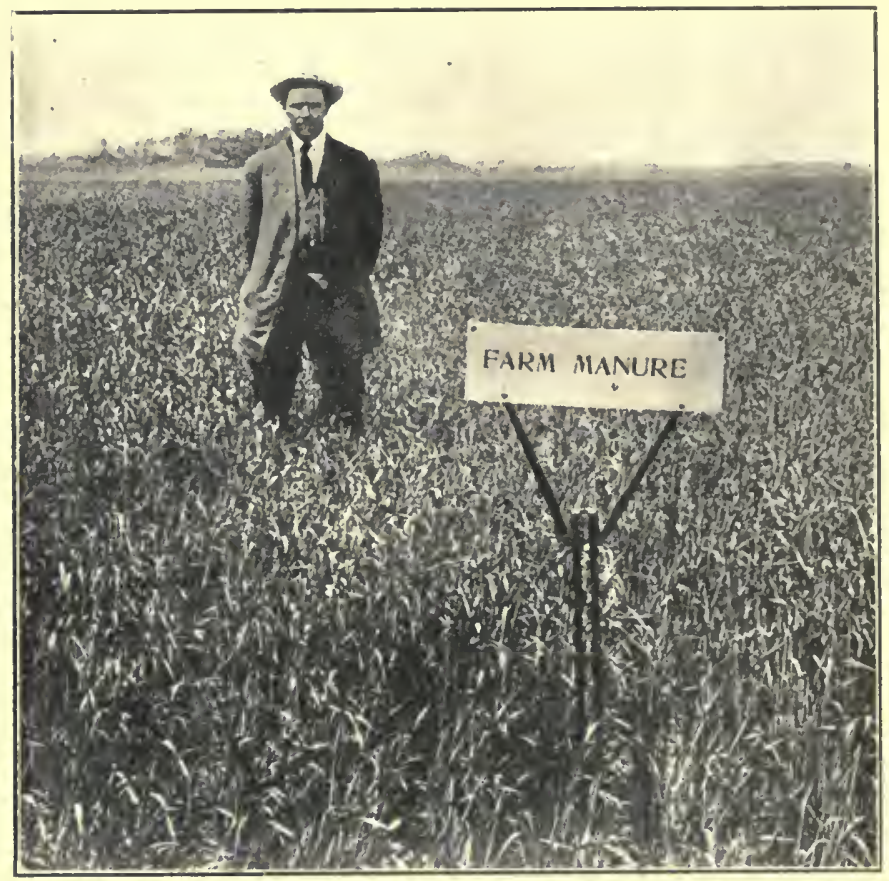

Fig. 21.-Illinols Soil Experiment.

Farm manure applied. Average yield 34.2 bushels per acre-Courtesy Illinois Agricultural Experiment Station.

the soil are maintaincd by plowing under all erop residues (straws, eorn stalks, all of the legume crops from which the seed has been removed, and also cover crops of legumes). The regular legume crops are so managed that a seed erop is secured if possible, and all resulting residues are returned to the soil. ....... When alfalfa is ineluded in the rotation it is harvested 
for hay in both systems ...... The residues from grain and legume erops may be plowed under direetly, or they

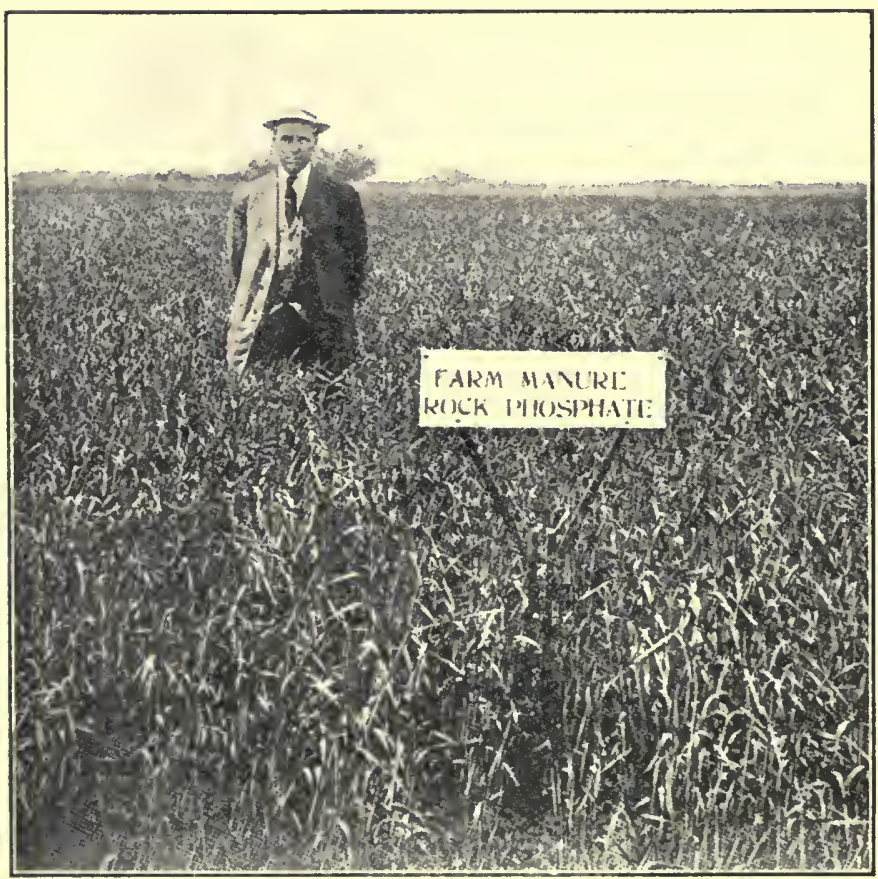

Fig. 22.-Illinois Soil Experiment.

Farm manure and rock plosphate applied. Average yield 51.8 buchels per acre. Phospliorus increased the yield 17.6 bushels per acre. The lessons taught are being put into practice by Illinois farmers. Figures 21 and 22 illustrate the result of scientific investigation, and though it should not be inferred that these results will accrue from the same treatment in Western Canada, the need for work of a similar nature is apparent. -Courtesy Illinois Experiment Station.

may be used as a top-dressing for the protection of winter erops and eventually turned under."

The methods of soil enrichment illustrated by this experiment have eome into common practice in Illinois and several of the adjoining states. Thus nitrogen and 
organie matter are supplied by manure and erop residues (ineluding legumes used as green manure, ete.). Commereial nitrogen, such as sodium nitrate, does not pay under extensive systems of farming. When the land is acid (sour) ground natural limestone, made from erushing limestone found in natural deposits, is most effectual and eeonomical. To supply phosphorus, finely ground, natural raw roek phosplate is applied, being the eheapest form, and, under humid conditions when applied with aetively deeaying organie matter, being as effective as the more readily available but more expensive aeid phosphate.

The practices of the more humid Corn Belt will not apply in full to Western Canadian conditions. Inder semi-arid eonditions, our soils cannot handle the anomits of crop residues or manure that are turned under in the humid regions. However, with the depletion of organie matter and nitrogen our system must be ehanged. Mixed farming is undoubtedly beeoming more general and the manure should be earefully conserved. But this will never entirely supply the soil needs for organie matter and nitrogen. The use of leguminous erops in the rotation will be a big step in advanee.

It is interesting to note in the Illinois Experiment that where the needs of the soil are fully provided for (plots 6 and 7 ) the grain system is equal, if not slightly superior, to the live stock system of farming. Thus, it is possible in the Corn Belt to farm entirely without live stock. The Canadian prairies may always be devoted ehiefly to grain farming, and if our agrieulture is to be permanent and profitable, we must plan our systems for eonditions as they aetually exist. Only by longcontinued, carefully condueted experiments such as the 
Rothamsted and Illinois experiments can our problems be solved.

42. Soil Acidity and Liming the Land.--Soil acidity (sourness in soil) is a common problem in the humid elimates, especially in the older agrieultural regions such as England, the continent of Europe, and eastern United States. Where soils are aeid, finely ground natural limestone rock has been found to be the cheapest and most effeetive. It is applied at the rate of one to two tons per acre, depending upon the degree of acidity in the soil. The soils of the arid and semi-arid regions are more likely to be alkaline than acid (alkaline is the opposite of acid) due to the fact that alkaline salts and limestone are not lea e hed away as in humid sections. Iimestone is

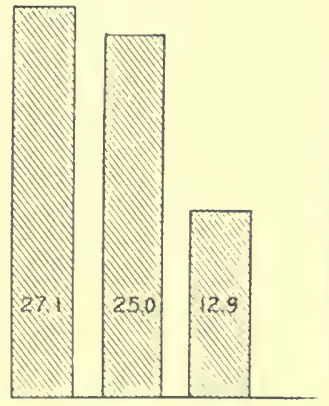

Fallow Legume Ou'Crop Rotation Rotation System WHEAT

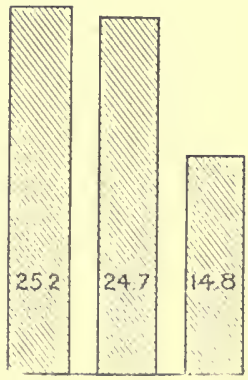

Fallow Legume one ('rop Rotation Rotation System BARLEY

Fig. 23.-Rothamsted Experiments.

Chart showing yields of wheat and barley (bushels) in good systents of crop rotation, and in one-crop systems. Figures represent 60-year averages in rotation systems, and 55 -year averages in one-crop systems.

present in sufficient quantity in most Western Canadian soils, so that this question need give us no eoneern.

43. Crop Rotations and Soil Fertility.-From Table XIII. we see that barley grown at Rothamsted, England, (Agdell field), in a rotation withont fertilization produced as an arerage of 60 rears, 24.7 bushels in the 
legume system and 25.2 bushels in the fallow system. In this same rotation wheat produced 2.5.0 and 27.1 bushels respectively.

In another field (Broadbalk Ficld) wheat has been grown continuously for 55 years unfertilized, the average yield being 12.9 bushels. In still another field (Hoos Field), barley has been grown continuously for 55 years, unfertilized, the average yield beeing 14.8 bushels. This is positive proof of the benefit of crop rotation over a one-crop system. It was pointed out, however, from table XIII., that crop rotation without fertilization would not maintain the erop yields. The matter of crop rotations is discussed fully elsewhere and it is intended here only to emphasize the fact that whereas a rotation is much superior to a one-erop system, provision should be made in the rotation for the return of organic matter and nitrogen and the mineral plant-food elements, especially phosphorus, if deficient. Crop rotation with no return of plant food is only a more efficient way of robbing the soil; it makes possible greater crops, whicl means the withdrawal of greater amounts of plant food and therefore more rapid depletion of the soil's fertility.

\section{The Soll a Living Mass.}

44. Importance of Microorganisms in the Soil.-We have seen that animals are dependent upon the higher plants. In turn the higher plants are dependent upon microörganisms. If the action of the latter were stopped for any considerable length of time, life would become impossible upon the earth; our very existence depends upon them.

The question might well be asked: What would be the condition of the earth, if, through the many ages, the 
dead bodies of animals and plants had simply remained upon the surface of the earth and had not decayed into an unrecognizable, powdery mass in the soil? The layer of trash would soon become so deep that seedlings upon the ground would find it impossible to push their way up into the sunlight; there would be no room for animal life; the earth would become uninhabitable. The lower organisms perform a great service in reducing the remains of plant and animal life to the black residue in the soil which, we call "humus". The humus represents but a small portion of the great bulk, the greater part being released into the air in the form of gases and water vapor, through the action of our infinitely small friends.

But this does not tell the whole story. We have shown that plants require food as well as animals, and that this food is derived from the soil, air and water. The materials from these sourees would have long since be come exhausted if it were not possible to use them over and over again. Thus we speak of the "cyeles" of the plant-food elements, and in these the lower organisms play the leading part. In the decay of plant and animal matter, carbon dioxide gas is given off, and this carbondioxide can again be used by living plants as before explained. In a similar manner nitrogen may be used over and over again, and likewise phosphorms, though instead of a gas these substances are converted into nitrates and phosphates, in whieh form they become available to plants. The eycle is not always so simple. It is the business of the microörganisms to prepare the food for the higher plants, and the plants and animals in turn furnish the food and energy through which microörganisms can do their work. The one depends upon the other'. 
People lave become accustomed to thinking of the bacteria and fungi wholly as enemies; we think only of the ravages of disease. The science of bacteriology lias developed more along this line. In our farm practices i.e. plowing, eultivation, manuring, ete., we give little heed to the consideration of the effects of these operations on the bacterial activities of the soil. It is fortunate indeed that the practices which favor the production of crops from the plant standpoint are also favorable to the activity of the beneficial bacteria.

45. The Soil a Living Mass. - The soil is inhabited by five kinds of microörganisms, bacteria, fungi, algae, yeasts and protozoa. The first four are vegetable or plant forms of life, the last, protozoa, are miscroscopic animals. Of the five groups the bacteria and fungi are most important. It is with the bacteria that we are mainly coneerned, though the fungi take part in many of the useful activities in the soil.

The numbers of the bacteria in soils vary with the type of soil, season of the year, moisture present, ete. The number may vary from several million per gram in a thin, poor soil, to a thousand million per gram in sewage farmed land. If, on ordinary soil, we assume a content of $60,000,000$ per gram, 27,216,000,000 per pound of soil, not at all an unreasonable or unusual number, we find that the surface $62 / 3$ inehes of soil over an acre (2,000,000 pounds) would contain a live weight of bacteria equal to 250 pounds. This would represent a volume of about 3.8 eubic feet. These figures bring out the very great numbers of the baeteria and their extremely small size. Due to the very great numbers ever present, the soil has frequently been spoken of as a "living mass". 
In general, light sandy soils have fewer numbers than the heavier, richer, types. The amount of food (organic matter) has an important bearing on the number of bacteria. Also virgin soils have lower counts than cultivated soils, due in part at least to the fact that cultivation, especially deep plowing, increases the depth of their operations by giving better access to air (oxygen). The greatest numbers occur between the fourth and sixth inch levels in average soils. This, of course, varies greatly. Soils may be sterile at three feet if impervious in nature, and are not infrequently sterile at a depth of eight or ten feet. As would be expected the highest numbers are found in the spring and fall. Owing to the heat and lack of moisture, the numbers are reduced in midsummer. In winter many of the vegetative forms are killed and great numbers go into a spore or resting stage to await more favorable conditions.

46. Funetions of the Bacteria in the Soil.-The functions of the bacteria in the soil may be classed umder four heads :

1. Destruction or decay of dead matter.

2. Preparation of available plant food for plants.

3. Parasitism (disease).

4. Symbiosis.

The activity of the bacteria in bringing about the decay of plant and animal remains has already been alluded to. In farm practice this aceounts for the decay and incorporation with the soil of the stubble, straws, corn stalks, manure, ete., that are plowed under. These substances under the action of the bacteria are decomposed, part becoming dissipated into the air as gases 
and water vapor, the residue, humus, beeoming a part of the soil mass.

47. Preparation of Available Plant-food.-The growing plant has need of an ever-present supply of plant food that is soluble and may be taken up readily by the roots. The baeteria are always at work preparing this food, and should their aetivity be stopped for any considerable period of time, the plant would suffer and die of starvation. Though eoneerned in the liberation of all plant-food elements, the relations of the bacteria to nitrogen are especially important.

48. The Nitrogen Cycle.-Farm erops depend upon the soil for their nitrogen, and this nitrogen must be in the form of nitrates to be utilized by plants. (Legumes are an exception and when inoeulated, they may draw upon the nitrogen gas of the air). Chile salt-peter (sodium nitrate), a common fertilizer, represents sueh a form which is available to plants. The nitrate is absorbed by the roots and is built up into protein in the plant. The latter may be eaten by an animal, the protein then becoming a part of the animal body or may be voided in the manure. The original bit of nitrate may, therefore, exist in altered form as a part of the prairie sod, of the wheat stubble, or of the animal flesh or manure. If returned to the soil and plowed under, before it ean again be used by plants, it must go through a preparatory proeess. First the plant or animal remains must undergo deeay or decomposition, the nitrogen being converted into ammonia. A great many kinds of bacteria in the soil may take part in this process, the end produet in every ease being ammonia. ('ertain bacteria in the soil (the nitrous aeid baeteria) seize upon this ammonia and eonvert it into nitrite, a nitrogen com- 


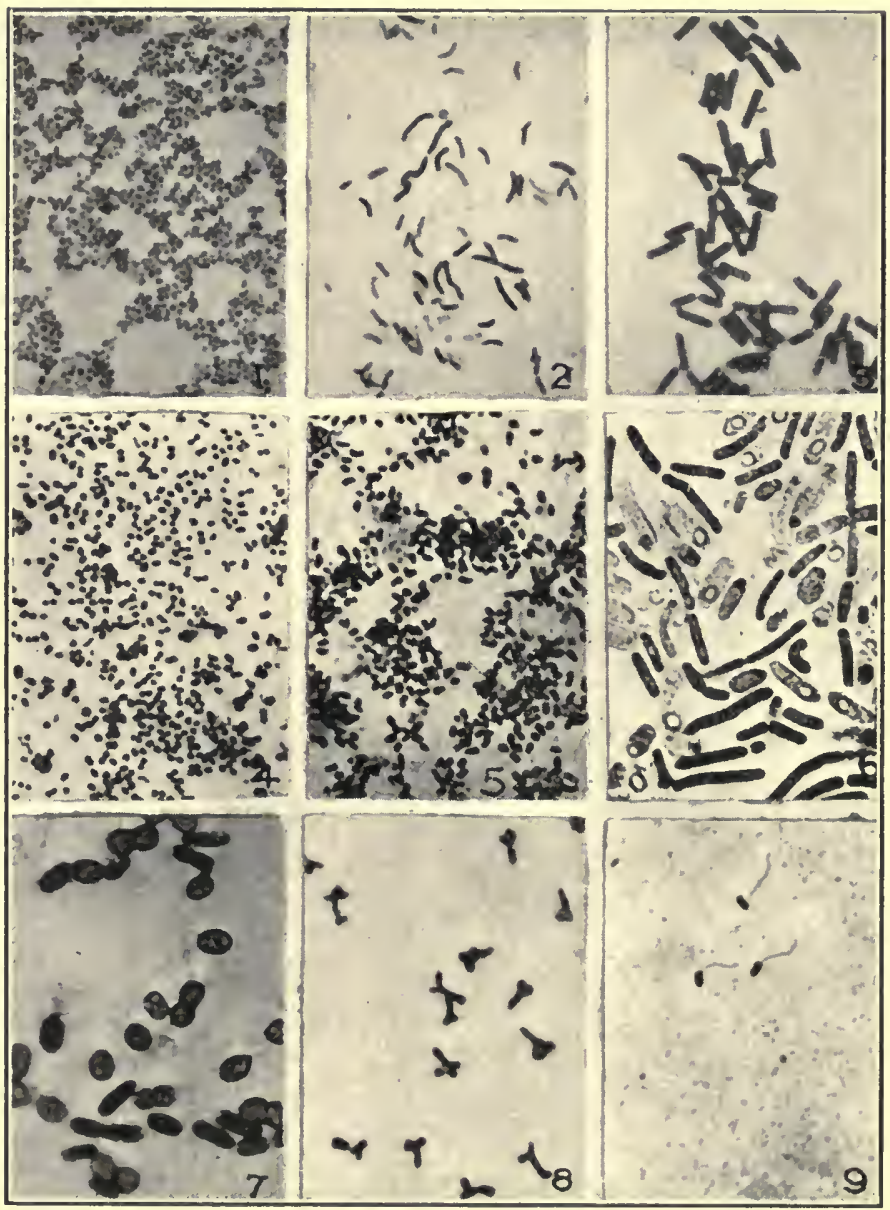

Fig. 24.-Soil Bacteria Magnified Over 1000 Diameters.

1. Micrococcus ureae, produces ammonia from urea; 2. Bacillus flores. cens, produces ammonia in soil; 3 . Bacillus subtilis, produces ammonia in soil; 4. Nitrosomonas (after Winogradsky), changes ammonia to nitrite; 5. Nitrobacter (after Winogradsky), changes nitrite to nitrate; 6. Clostridium pastorianum, showing spores, free-living nitrogen-fixing organism; 7. Azotobacter chroücoccum, free-living nitrogen-gathering bacteria; 8 . Nodule bacteria from vetch, showing characteristic branched forms; 9. Nodule bacteria, from soy-bean, showing flagella. 
pound eontaining oxygen. Another species of baeteria (the nitric acid bacteria) then converts this nitrite into nitrate, through the further addition of oxygen to the nitrogen. $\Lambda$ s nitrate, the nitrogen may then be used again by plants.

Certain losses of nitrogen through bacterial action are likely to oceur, especially in the manure pile. "Firing" or "fire-fanging", due to the rapid decomposition of the manure, results in the escape of nitrogen to the air in gaseous form. The process is called denitrification and is due to bacterial action. A similar process oceurs in soils, especially when water-logged, but the losses from this source in well-tilled soils are not appreciable.

On the other hand, additions to the soil's supply of nitrogen may oeeur in several ways. Small amounts are brought down from the atmosphere by the rain and snow, chiefly as ammonia and nitrie acid. In the soil certain bacteria (Azotobacter) living upon the carbonaceous material in the soil, have the ability to extract free nitrogen gas from the air and build it up into their bodies. These sources, however, are not of great magnitude. A third source, the fixation of nitrogen by leguminous plants, will receive due consideration.

49. The Mineral Plant Food Elements.-In the deeay of organie matter, carbonic aeid and many other organic acids are formed. In the nitrifieation process nitrous and nitric acid are formed, not as free acids but united with the basie substances, among them the essential plant food elements as calcium, magnesium and potassium. These substances, oecurring in the soil in insoluble compounds, are rendered soluble by this process. Phosphorus ocemring chiefly in the soil as the insoluble tricalcium phosphate becomes soluble and available to 
plants through the solvent action of the organic acids. By the nitrification process it is converted from the insoluble form to the soluble acid phosphate in which form it may be used by plants.

These principles find application in practical agriculture. The results of the Ohio and Illinois stations have shown that the crushed raw rock phosphate applied with liberal amounts of farm manure (or erop residues) gives yields that are equal to the acid phosphate, and at considerably less expense. The failures to secure results upon soils deficient in phosphorus by the use of raw rock phosphate have been due to the failure to provide decaying organic matter. Nature has wisely locked up the phosphorus in the soil in insoluble form so that it will not be wasted, but has beneficently provided a means whereby it may beeome available to plants. The "why" in agricultural practice is as important as the "how"; it is the safest guide to a permanent and profitable system.

50. Parasitism (disease).-That the soil harbors many disease-producing microörganisms is now a matter of common knowledge. Among the bacterial plant diseases crown gall, pear blight, black leg and soft rot of potatocs, are typical examples, and among the fungous diseases flax wilt, wheat rust, and the smuts. These organisms, horrever, are not related to the fertility of the soil.

51. Nitrogen-fixation by Leguminous Plants.-Threefourths of the atmosphere ly weight is nitrogen gas; over one acre of land there are 70 million pounds of nitrogen, enough for nearly a million bushels of wheat if it were available to that erop. But wheat cannot utilize directly the free nitrogen gas of the air. 
Certain plants, the legumes, have the ability when inoculated to draw upon the air for nitrogen. Red clover, sweet elover, alfalfa, peas, beans, and vetel are examples of leguminous plants. These plants do not have the power in themselves to take up free nitrogen gas. It is through eertain bacteria, the nodule bacteris, which live in the soil that this is made possible. These bacteria

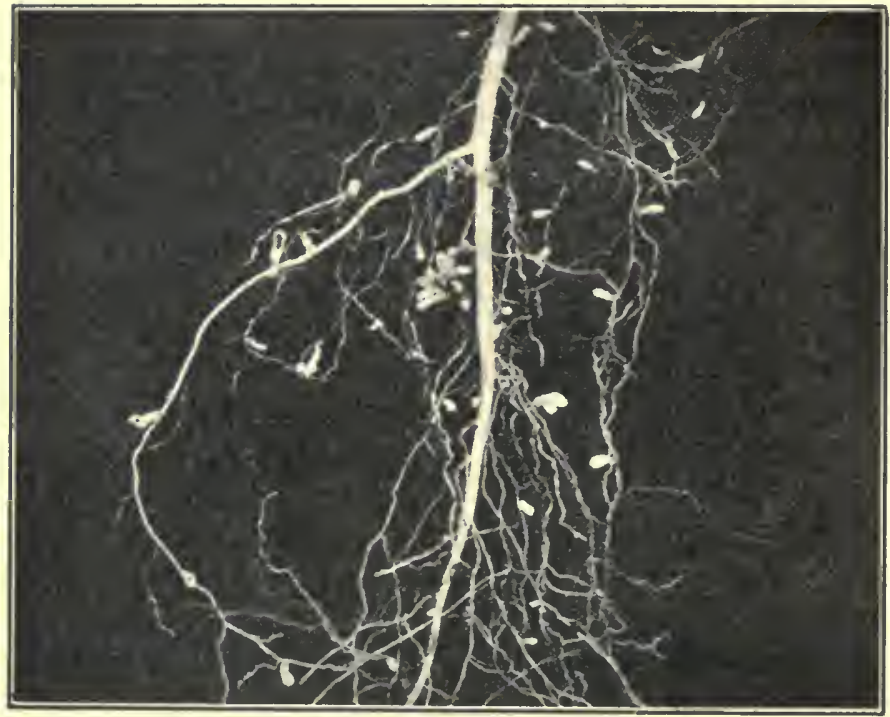

Fig. 25.- Nodules on the Roots of Alfalfa.

These nodules are the homes of millions of alfalfa bacteria which gather nitrogen fror.t the air and turn it over to the plant.-Courtesy Wisconsin Agricultural Experiment Station.

attack the root-laairs of the legume plant, causing the formation of gall-like struetures called nodules upon the roots. In these nodules the bacteria live and multiply, extracting from the plants the sugars and 
other materials neeessary for their life processes. In return they absorb the nitrogen gas from the air, which eirculates through the soil, and turn it over to the plant in a form that the plant ean utilize. Without the presenee of baeteria and without the presenee of the nodules this process would not go on. The legume plants would behave like ordinary erops, using only the nitratenitrogen found in the soil.

This proeess is termed symbiosis, which means that the two organisms, the baeteria and the plant, live together to their mutual benefit. Thus the bacteria are provided with a home (the nodule) and food (sugar), and in turn they supply the plant with an inexhaustible nitrogen supply. Neither is injured by the union, but on the other hand both are greatly benefited.

If legumes are grown in soil which contains no nitrogen but are inoeulated and given all the essentials for growth exeept nitrogen, the plants will live and thrive normally, extracting in this case, through the aid of the bacteria, their entire nitrogen supply from the air. If, on the other hand, the soil eontains nitrogen, it will draw in part upon this and in part from the air. Aeeordingly as the soil is richer in nitrogen, especially as nitrate, the plants will draw more heavily upon the soil and less upon the air for their nitrogen. Hopkins has figured that upon normal soil of average fertility, red elover when inoeulated seeures about $2 / 3$ of its nitrogen from the air and $1 / 3$ from the soil. When ent for hay the part removed contains $2 / 3$ of the nitrogen present in the entire plant, the roots and stubble containing $1 / 3$. Thus when the hay is removed, as mueh nitrogen is removed as was obtained from the air. The stubble and roots turned under do not produce any gain for the soil, the 
same amount being turned under as came origina!ly from the soil. This, lowever, is a great advantage over other hay crops where every pound of nitrogen removed represents a loss to the soil. But every ton of clover tops contains forty pounds of nitrogen, so that every

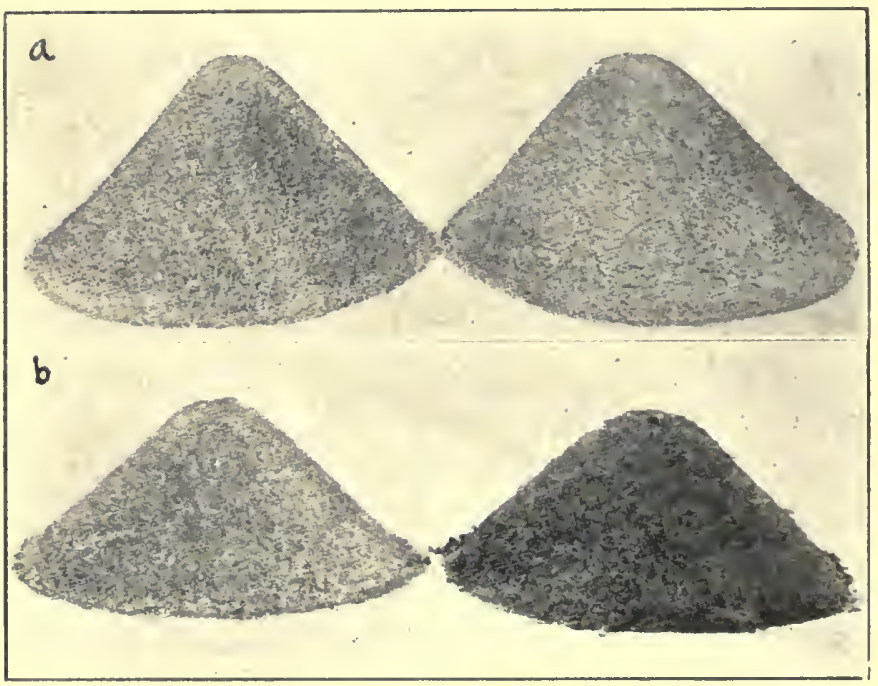

Fig. 26.-Bacteria in Relation to Soil Building.

(a) Two piles of pure white sand. (b) The pile of sand on the left on which four crops of uninoculated legumes have been grown and to which nothing has been added is still white infertile sand. The pile on the right on which four crops of legumes and legume bacteria have been grown and to which nothing else has been added is well on the way to become a fertile soil as is shown by its dark color.

ton of clover turned under for the purpose of soil enriehment represents a gain to the soil of forty pounds of nitrogen.

Sweet clover tops contain on the average 40 to 50 pounds of nitrogen per ton, so that every ton of sweet clover tops turned under for soil enriehment is worth 
four to five tons of manure from the standpoint of nitrogen (manure eontains 10 lbs. of nitrogen per ton). This together with the tonnage that it produces, explains why sweet clover is becoming so widely grown for improving the soil in the humid sections. The sueeulence of the plant renders it easily and quiekly decomposed by the bacteria, making possible the turning under of very great amounts. This then furnishes a large amount of organic matter, and the nitrogen through bacterial action becomes available to suceeding erops. The result is that the corm or wheat "rops following are frequently doubled, and the effect is not limited to the one year following, but is apparent for several years through inereased yields. Such practice must eome into vogue in the Prairie Provinces when the organie matter and nitrogen supply need replenishing.

It should again be emphasized that in order to seeure nitrogen from the air the legumes must be inoculated. The bacteria may already be present in some soils and if so they will make their presence known by forming nodules on the roots of the youmg plants. If the nodules are not formed, it is positive proof that the bacteria are not present, and upon such soils artificial inoculation, either applied as a eulture to the seed or applied by spreading and disking in some well-infected soil from a field known to be inoculated must be resorted to.

In applying inoculation to the seed different kinds of nodule baeteria must be used for eertain legumes. Alfalfa and sweet clover require one kind, peas and veteh take another, while the true (lovers, red ('lover, mammoth clover, white elover, alsike elover, require still another. The baeteria which produce nodules on the roots of alfalfa and sweet elover will not produce 
nodules on the roots of peas, vetch or the true elovers. The groups are absolutely distinet.

\section{The Factors of Soll Fertility.}

52. The Measure of Fertility.-The measure of the fertility of the soil is the erop it produees or can be made to produce. This is not the result of any one faetor, but of a combination of faetors.

The physical make-up of the soil determines in part at least the extensiveness and effectiveness of the rootsystem of the plant. It is concerned with the ability of the soil to absorb and retain moisture. It affects the tilth, the air supply and the warmth of the soil.

The chemical composition of the soil determines its potential possibilities. Sinee we know the kinds and amounts of plant-food elements that our crops require, and since ehemical analyses will tell us the total amounts present in any particular soil, we have an index to the fertility of that soil. We have a means of discovering the deficiencies, and when confirmed by aetual field tests, this is the safest guide to good practice.

The bacteria are concerned with the liberation (making available) of plant food. This is brought about through the organic matter supplied. The value of organic matter is therefore apparent. It furnishes the food and energy for the bacteria which when thus supplied make plant food available (soluble) for the plant. In addition the actively decaying organic matter is the source of humus in the soil.

Permaneney in agrieulture depends upon the control by man, in so far as is possible, of the factors essential to the production of erops. The stock of materials in the 
soil when diminished to the point that crop yields are limited, must be replenished. By making provision for the return of organic matter we provide for the needs of the plant for available plant food. It should be the business of every progressive farmer to give as much thought to the soil he is working as he does to his farm machinery or animals. Just as his farm animals and machinery fail to give good returns from bad treatment, so the soil will likewise fail to produce profitably under irrational treatment. 


\section{CHAPTER IV.}

\section{THE MOISTURE PROBLEM}

Water is required in large amounts by growing plants and the source of all moisture for erops, except under irrigation, is the clouds. The average precipitation is a general guide to the amount that is likely to fall in any year. Areas having more than 30 inches precipitation are spoken of as humid; those having between 20 and 30 , sub-humid; between 10 and 20 inches, semi-arid; while those having less than 10 are called arid. Most of Western Canada is semi-arid; our average precipitation is low and the water requirements of growing crops is high; the chief cause of low yields is laek of moisture.

The moisture problem briefly stated eonsists of (1) storing as mueh moisture as possible in the soil, (2) conserving it as well as we ean, (3) keeping it available to the seed and plant roots, and (4) making the most efficient use of it.

53. Storing Moisture in the Soil.-When moisture falls upon the land in the form of rain it is either absorbed by the soil or it finds its way to ditehes, lavines or sloughs. The problem of storing moisture is one of preventing the "run off" which oceurs chiefly at two seasons, one during the heavy midsummer rains and the other when the snow melts in the spring. The amount 
of "run off" is largely determined by (1) the topography of the land, and (2) the openness or receptivity of the soil.

The topography eannot be altered but some loss of water may be prevented by tilling erosswise of the main slopes. The more open the soil is at the time of the heavy rains or when the snow is melting the more

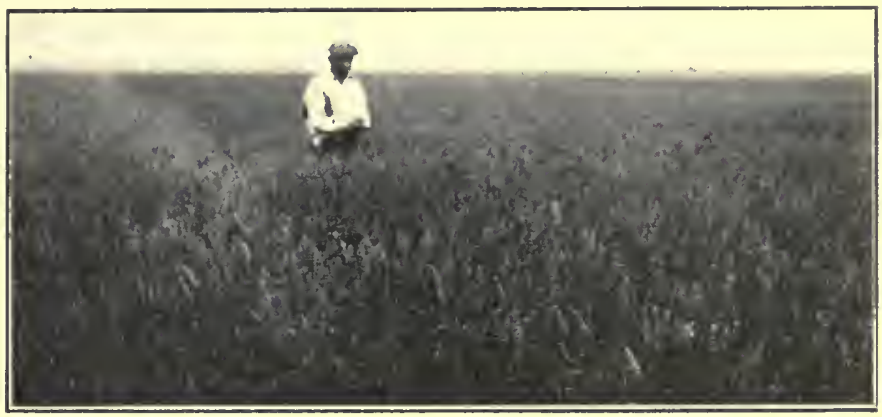

Fig. 27.-Wheat Under Irrigation near Strathmore, Alberta.

moisture it will take in and the less "run-off" there will be.

The storage of moisture in "old" land is aceomplished by:

1. (a) Fallowing the land once in two, three, four or five years, depending upon the average preeipitation and evaporation.

(b) Plowing or otherwise eultivating the fallow early to lessen the possible "run-off" after heavy rains.

2. Using sueh intertilled erops as may not require all the water, thus permitting of the storage of some;

3. Using erops that may be harvested early, thus per- 
mitting the land to lie fallow and accumulate moisture for a longer time in the fall;

4. Increasing the organie matter eontent of light soil types so as to inerease their moisture-holding power and deerease the loss of moisture by percolation.

The storage of moisture in new or prairie land or sod land is aecomplished by

1. Breaking and leaving idle for a year (less in some areas) in order to make the land reeeptive for the summer rains;

2. Breaking early in order that the loss of moisture through the growth of native vegetation may be prevented;

The storage of moisture in stubble land is aceomplished by

1. Leaving a long stubble to hold snow which on melting adds water to the soil; or

2. Cultivating with dises or even by shallow plowing early in the fall so that the soil may be put in a condition to absorb more of the water from melting snows. (Note that (1) and (2) are not possible on the same area).

54. Conserving Moisture in the Soil.-Moisture that has been stored in the soil may be lost in one or more of only three ways:

(1) by seepage or drainage through the soil,

(2) by evaporation from the surface into the atmosphere,

(3) by passing out through the stems and leaves of growing plants in the natural processes of growth.

The loss through seepage or drainage is very little in dry elimates exeept on light or eoarse grained soils or soils having a subsoil that is sandy or gravelly. On 
such soils the lessening of seepage ean only be brought about by increasing the organic matter content a practice which is seldom profitable except on the better grades of these types of soil. The dry farmer should avoid soils that are so light and loose that loss by seepage is probable.

The loss of moisture by evaporation from the soil into the atmosphere is very great. No data giving the actual amount of loss from a soil surface in this climate are available, but when it is realized that from 60 to 100 inches of water evaporates from a water surface in a year in the southern portion of the Great Plains, the extent of the evaporation from a soil surface may be imagined. The very great loss by evaporation may be lessened (1) by the use of a mulch on the surface of the land, and (2) by increasing the moisture-holding power of the soil by maintaining or increasing its supply of humus or partially decomposed organic matter. While it is a fact that a soil mulch lessens the amount of water that leaves the soil by evaporation in humid climates, there is some question as to its effectiveness in dry climates and also as to how much expense a farmer is justified in assuming in order to make a relatively small saving. (See "The Application of the Capillary Theory to Dry Farming Practices" in Chapter XVI.)

The loss of moisture through its use by growing plants is very great. $\Lambda$ s little as 250 pounds of water and as much as 1,000 pounds have been found to be taken into the roots of plants and transpired into the atmosphere through the leaves in the process of taking in food materials sufficient to makc one pound of dry matter. So long as the plants using it are useful to man this large amount of water is not a loss, even though it may hav. 
disappeared from the soil. But when useless plants or weeds use up the moisture it is a serious economie waste.

liecent investigations in soil moisture conservation emplasize the belief that under normal soil conditions weeds are not the secondary but the ehief means by which moisture is lost from the soil. They also indieate that tillage for moisture conservation should have as its pratical aim* (1) the control of weed growth, and (2) the prevention of soil craking or soil baking, or the

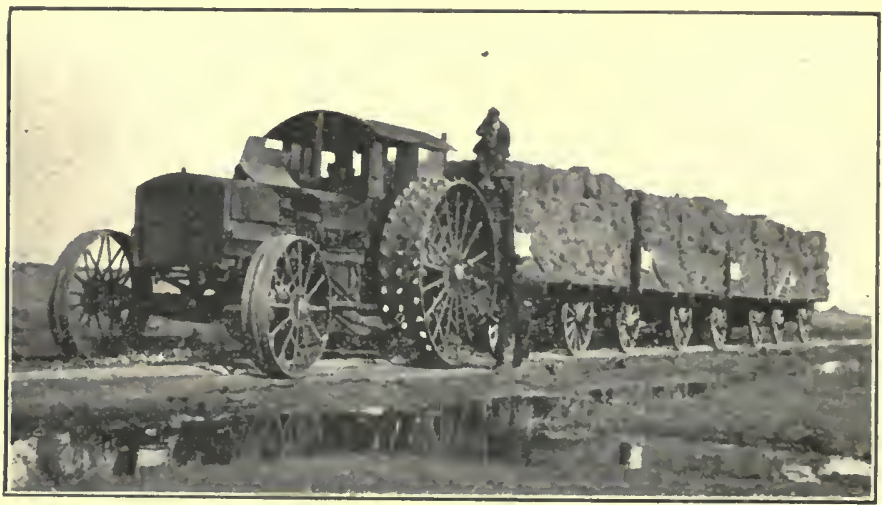

Fig. 28.-Hauling Alfalfa Grown Under Irrigation at Coaldale, Alberta.

drying ont of the furrow slice. If these aims are fully attained it seems probable that any extra tillage will not result in a sufficiently increased return to pay for the extra work.

The practices by which the moisture stored in the fallow can be conserved are:

1. Early harrowing or packing after plowing in order to lessen exeessive evaporation from the furrow slice, 
2. Sufficient surface cultivation to kill weeds, grass and volunteer grains, which use up water in the process of growth.

3. Sufficient surface eultivation to prevent the soil from eraeking, and therely inereasing the evaporating surface.

The conservation of moisture "stored" in breaking is accomplished by :

1. Packing or "planking" immediately after breaking - so as to lessen the loss of moisture from the furrow slice and the subsoil by the drying winds.

2. Disking and harrowing as necessary to control weeds and grass.

The eonservation of the limited moisture supply in stubble land can be effected by :

1. Fall plowing of grassy land to kill the grass and thus save the water the grass demands for growth,a practice which may be nentralized in the very dry parts by inereased evaporation from the overturned furrow slice.

2. Early harrowing or packing of all spring-plowed land in order to protect the furrow slice and sulbsoil from the drying effect of the winds.

3. Harrowing early in the spring before sowing, $\mathrm{Ol}^{\circ}$ harrowing such crops as cereals, eorn and potatoes after they are up in order to control weed growth or prevent the soil eraeking. This practice cannot be followed indiseriminately on all soils, as on some it will result in inereasing the danger of soil drifting.

55. Keeping Soil Moisture Available.-Making the hest possible use of the moisture stored and conserved in the 
soil is not the least important of the problems of the dry farmer. It may be considered under two heads:-

1. How to keep a supply of it continuously available to the seeds in the soil or to plant roots, and

2. How to make it serve its purpose most effieiently.

Of the three forms in which moisture oceurs in the soil, viz., free water, eapillary water and hygroscopic water, only that in the eapillary form is of immediate value to growing plants. The small portion known as hygroseopic moisture, which is present about the soil particles when they are air dry is held so firmly that plants eamnot extract it. The free water, that portion found filling the spaces between the particles of a soil which is flooded, is of very great value as a source of supply even though it cannot be drawn upon direetly and is sometimes harmful to plants. Free water when present in the subsoil may be changed to capillary or film water, in which form it may move up or down or in any other direetion or be held by the soil even against gravity. It is in the eapillary form only that water may be drawn upon by plants.

In the praetice of erop growing it frequently happens that something is done which either lessens the chanee of the plant getting at the moisture in the soil or what is of equally serious coneern, makes it diffieult or impossible for the moisture in the subsoil to move to where the seeds or plant roots are. Thus when coarse manure or long stubble are plowed under in fall $01^{\circ}$ spring in preparing for a erop the next season, loose open spaces are ereated between the seed bed and the subsoil and the availability of even the eapillary moisture is interfered with. Similarly when coarse clods are plowed under, or the plowing left in rolls, or the fur- 
row left on its edge, or the land plowed when it is too dry, or allowed to bake after being plowed when too wet, open air spaces are created below the furrow slice which seriously lessens not only the moisture movement from the subsoil to the seed or to plant roots but also the ability of the roots to reach out after moisture. Moisture cannot rise through large, loose, open spaces in the bottom of the furrow slice, nor can plant roots g r ow down through them $\mathrm{s}$ a t is factorily. Obviously, these practices, unless modified, are unsuited to dry

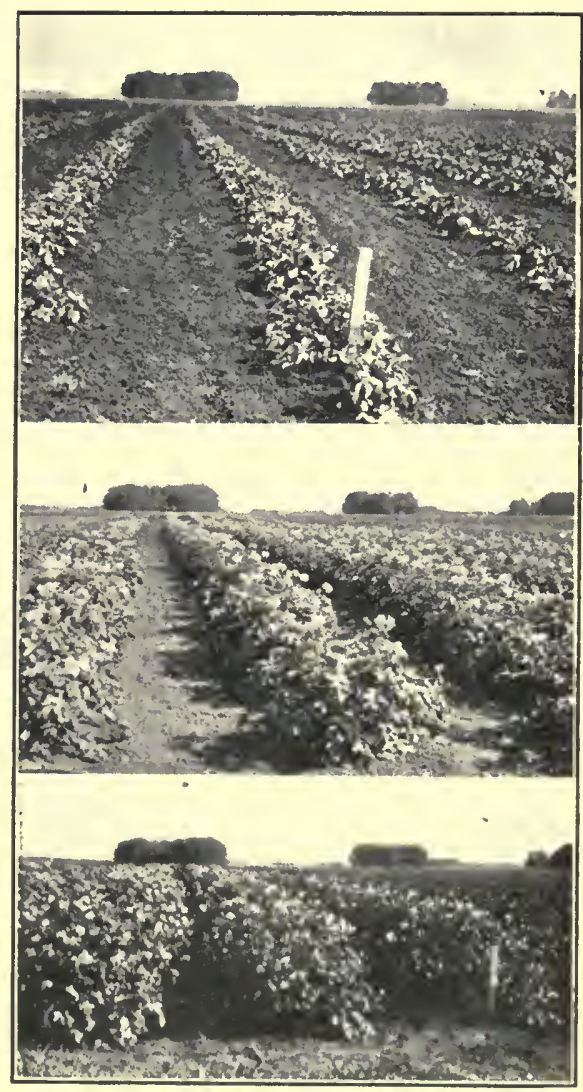

Fig. 29.-A Well Tilled Field of Potatoes.

Three stages of development in the growth of a field of potatoes.-Courtesy Dr. Seager Wheeler. farm eonditions.

The ehief means by whieh the moisture stored and 
eonserved in the soil is kept available, or at least not rendered unavailąble, are:

(1) By not plowing under thick layers of dense grass or other rubbish, unless time sufficient for its deeay is allowed before seeding the next erop.

(2) By not plowing under a heavy stubble in fall or spring unless the land is to be thoroughly compacted so that the moisture in the subsoil may rise into the furrow slice to meet the needs of the crop.

(3) By seeing that in all fall or spring plowing the overturned furrow is brought firmly in eontact with the subsoil, so that there may be the least possible interference with the free movement of moisture upwards from the subsoil.

(4) When applying manure, to put it on thinly and firm the soil about it before erops are sown, so that it will quickly decay and not interfere with the movement of soil moisture. Coarse, strawy manure and stubble are often worse than useless until they have deeayed, after which time they exert a very beneficial effect on the moisture-absorbing and moisture-holding eapacity of the soil.

(5) By leaving the soil in such eondition that the seed can get the necessary moisture for germination without having to be sown too deeply.

(6) By preventing the formation of a "hard-pan" below the furrow or by remedying it if it is already there.

56 The Efficient Utilization of Soil Moisture.-The soil moisture will be utilized most effieiently if three things are done: (1) the supply of available plant food kept up, (2) drought-resistant erops grown, and (3) suit- 
able crop management practices followed. The first of these is discussed in the next section and the other two in the chapter that follows.

57. Soil Fertility and Soil Moisture.-One of the ehief functions of the water stored in the soil is to dissolve plant food substanees and carry them through the root

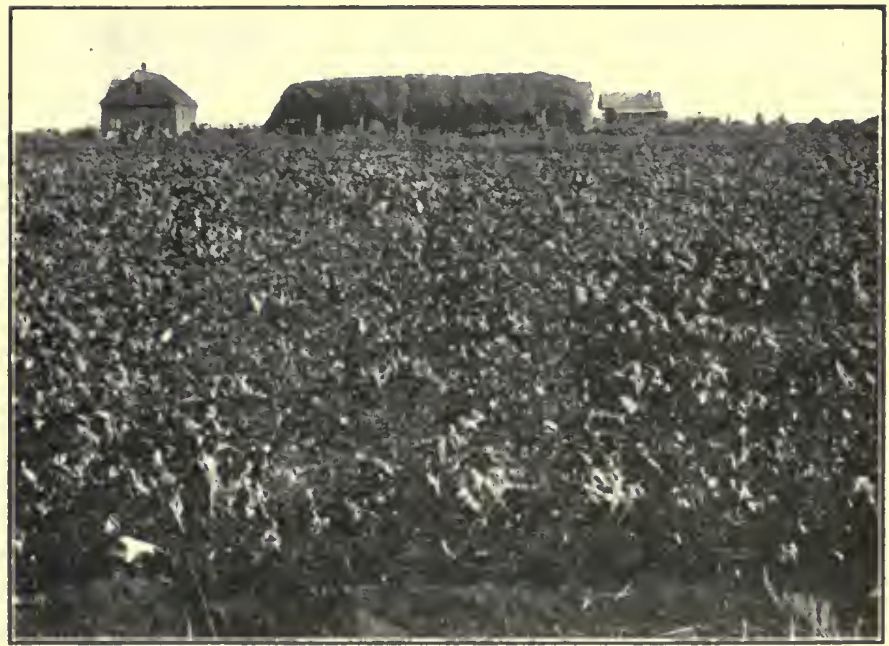

Fig. 30.-Sugar Beets Growing cn Irrigated Land North cf Brooks, Alta.

hairs into the plant. The more of such material a mit of water can carry into the plant the more bushels per acre the limited supply of water may produce. It has been found that when equal amounts of water are supplied to rich and poor soils the former produres the larger yield. Widtsoe* states (1) that on a naturally fertile Utah soil 908 pounds of water were required to produce each poumd of dry matter in corn, $(\ddot{z})$ that

* From "Dry Farming" by Widtsore. 
when this soil was manured only 613 pounds were required, and (3) that when commereial fertilizers were applied only 585 pounds of water were necessary to produce a pound of dry matter. Similarly he found that "on sandy loam, not eultivated, 603 pounds of water were transpired to produce one pound of dry matter in corn; on the same soil, eultivated, only 252 pounds were required. On a clay loam, not eultivated, 535 pounds of water were transpired for each pound of dry matter, whereas on the eultivated soil only 428 pounds were necessary. On a elay soil, not eultivated, 753 pounds of water were transpired for eaeh pound of dry matter; on eultivated soil, only 582 pounds."

While our soils are new and rieh an average rainfall will generally produce a fair yield. As soon as they become less "fertile" the same amount of rain is likely to produce a smaller erop. The results of theses investigations elearly show that the more fertile a soil is, the greater yield it will produce from a given supply of moisture. This is one reason why dry farmers should strive to maintain the "fertility" of their soils. 


\section{CHAPTER V.}

\section{DRY FARM CROPS AND CROPPING PRACTICES}

The chief crops that have been grown in the past in the three Prairie Provinces and the approximate acreage of each is shown by the following table: -

TABLE XV.-Acreage devoted to different crops in Manitoba, Saskatcherwan and Alberta in the year 1916.*

Manitoba Saskatchewan Alberta.

\begin{tabular}{|c|c|c|c|}
\hline Wheat--Winter & 3,829 & 15,259 & 18,177 \\
\hline "-Spring 1 & $2,721,896$ & $9,016,851$ & $2,586,798$ \\
\hline Oats $^{2} \ldots \ldots \ldots$ & $1,4+3,599$ & $3,791,807$ & $2,124,981$ \\
\hline Barley 3 & 687503 & 367,207 & 336,586 \\
\hline Ryet $\ldots \ldots \ldots \ldots \ldots \ldots \ldots$ & 30,050 & 22,759 & 17,975 \\
\hline $\ldots \ldots \ldots \ldots \ldots \ldots$ & 15,684 & 542,034 & 95,063 \\
\hline$\ldots \ldots \ldots \ldots$ & 1,600 & 650 & \\
\hline Mixed Grains & 1,400 & 14,150 & 4,550 \\
\hline Hay and Clover 5 & 77,642 & 25,154 & 173,461 \\
\hline$\ldots \ldots \ldots$, & 31,989 & 46,989 & 29,216 \\
\hline os, Mangels, etc. ...... & 3,118 & 1,621 & 1,700 \\
\hline 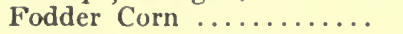 & 9,830 & 2253 & 675 \\
\hline Alfalfa $\ldots \ldots \ldots \ldots \ldots \ldots$ & 4,422 & 3,086 & 20,612 \\
\hline
\end{tabular}

1 Chiefly hard red spring, practically no Durum.

${ }^{2}$ Chiefly late maturing sorts.

3 Chiefly Six-rowed bearded hulled.

4 Both spring and winter.

5 Mostly native prairie-eonsiderable Western Rye-Brome and Timothy.

The above table is included here in order that the reader may note the relative importance attached by the present generation of farmers to the different crops now

* From Canada Year Book, 1916-17. 


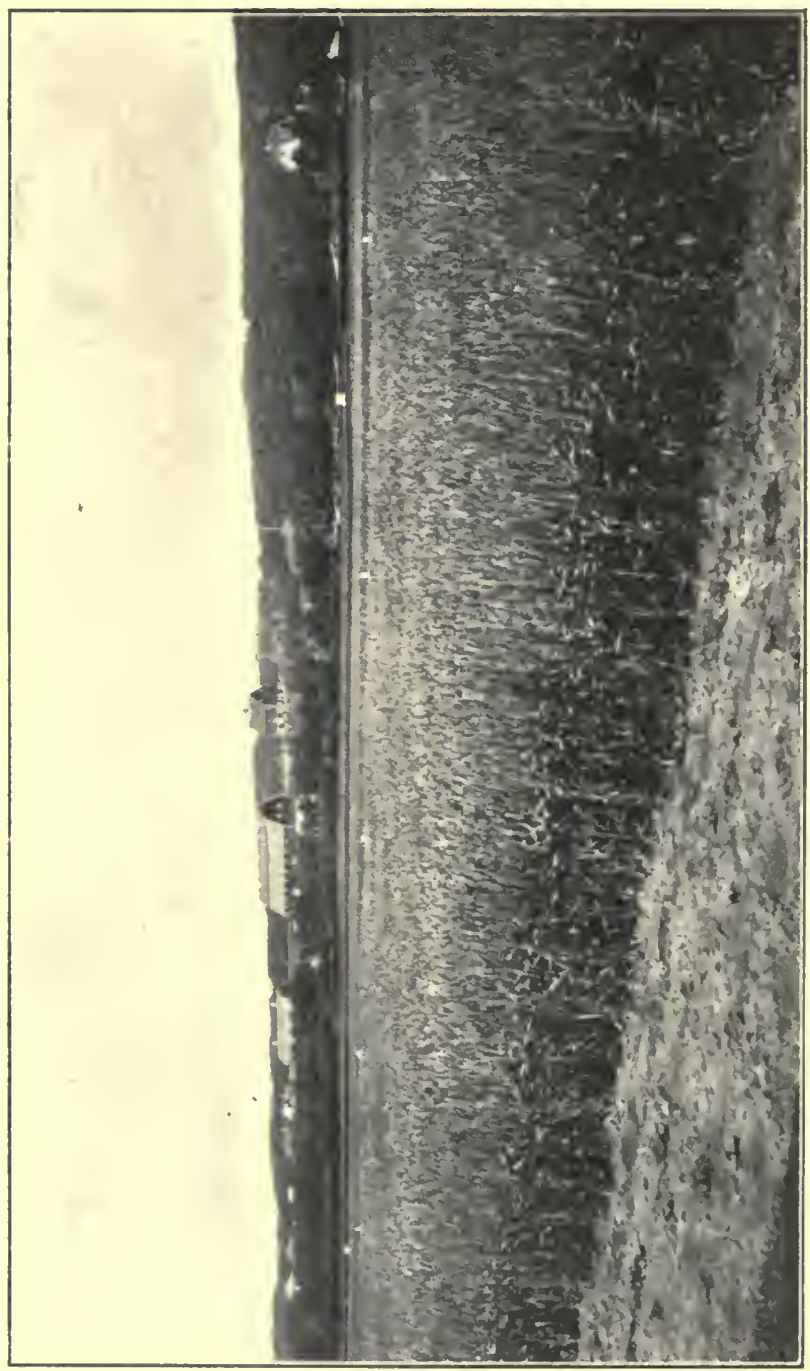


grown. What we are about to say in this ehapter should not be interpreted as suggesting that radieal changes should be made in the crops now used in those portions of the West that enjoy a rainfall of sixteen inehes or more, or that are outside the prairie area. The suggestions that follow are meant rather as a guide to those men in the dry belt who have found that the commonly grown erops have not given satisfactory returns.

58. Drought Resistant Crops.- The dry farmer should keep in mind that some plants are better able to withstand drought than others. The factors that constitute drought resistance are not all well understood but several are now quite well appreciated by dry farming investigators. For instance, it is now well known (1) that different erops require different amounts of moisture to produce a unit of dry matter, (2) that certain types of erops are able to withstand more drought than other's, (3) that the growth of some classes of erops so parallels the monthly distribution of rainfall that they produce larger yields than others, the growth habits of which are different-in other words they avoid drought-and ( $t$ ) that erops which permit of intertillage may develop better under similar precipitation than those not adapted to this method of culture.

Recent investigations have shown that among our eommonly grown erops millet, sorghum and corn require the least moisture per unit of dry matter prodnced; that the legume crops, like alfalfa, peas and clovers require the most-and that the grain crops-wheat, oats, barley and rye and flax-are intermediate in moisture requirements. 
Carefully conducted experiments have also shown that some crops will withstand drought better than others. For instance, brome grass and Western rye grass for some reason withstand more drought than any of the other commonly used grasses. Alfalfa will with-

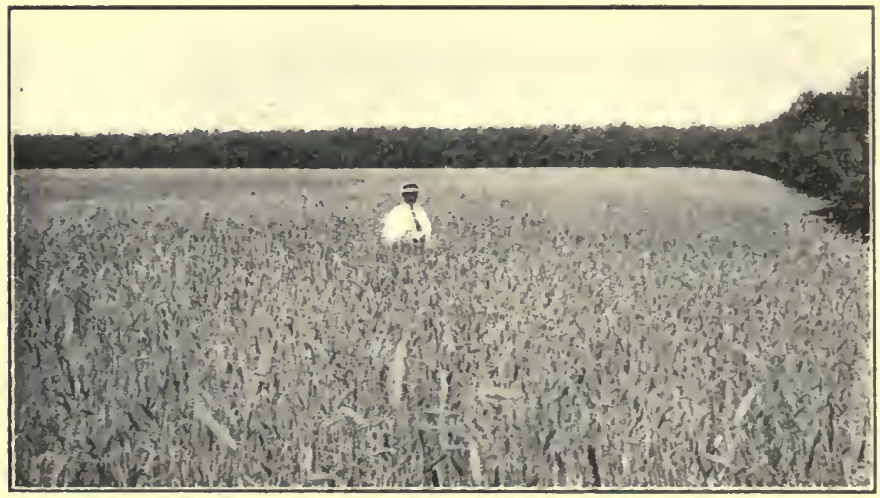

Fig. 32.-Winter Rye at Indian Head, Saskatchewan.

Although lower in price than wheat winter rye is a promising crop for the drier areas.

stand more drought than elovers, Durum wheat more than eommon wheat, and Emmer more than oats or barley.

It is well appreciated by western farmers that ammal crops yield much more than perennial ones, and that those crops which ean be sown early and that reach their greatest growth during the late stages of the rainy season, and that ripen before the dry autumn months are the most satisfactory to grow. This is why oats, an annual erop, is more generally used as hay than the grasses which are perennial. It explains why sweet clover yields more on dry land than alfalfa and it is the 
reason the grain crops are the ones best suited to our climate.

The value of intertilled crops, particularly those that are harvested early, as a preparation for grain crops, has long been appreciated by farmers in dry elimates. Very large yields after corn and fair returns after potatoes are of common occurrence. The diffienlty las been to grow these or similar crops profitably in a large way at the present time. The economic conditions now existing favor extensive rather than intensive methods for the average farmer in the West, although as land beeomes higher in price and labor and equipment relatively cheaper, more intensive methods will probably pay better than extensive ones.

The drought resistant or drought avoiding crops that are little grown but that promise much for the dry farming districts of Western Canada and that warrant very careful trial are:

Grain erops for sale-Durum wheat.

Rye-Winter and Spring.

Flax.

Grain crops for feed-Two-row barley.

Rye-Winter and Spring.

Emmer-(Value not determined.)

Early Maturing Oats-(Value not determined).

Corn-(Value not determined).

Forage crops for permanent pasture-Western rye grass and brome grass.

Forage erops for hay-Western rye grass, brome grass, oats, rye and sweet elover.

Forage erops for soiling-Alfalfa in rows and eorn, 
Forage erops for summer pasture-Sweet clover. Forage erops for fall pasture-Rape and winter rye. Forage erops for winter fodder-Corn and the straw of eereals.

Forage erops for sueculent winter feed-Corn, oats and sunflowers.

59. Durum Wheat.-This is a bearded wheat, long and stiff in the straw, nom-hattering and rust and drought

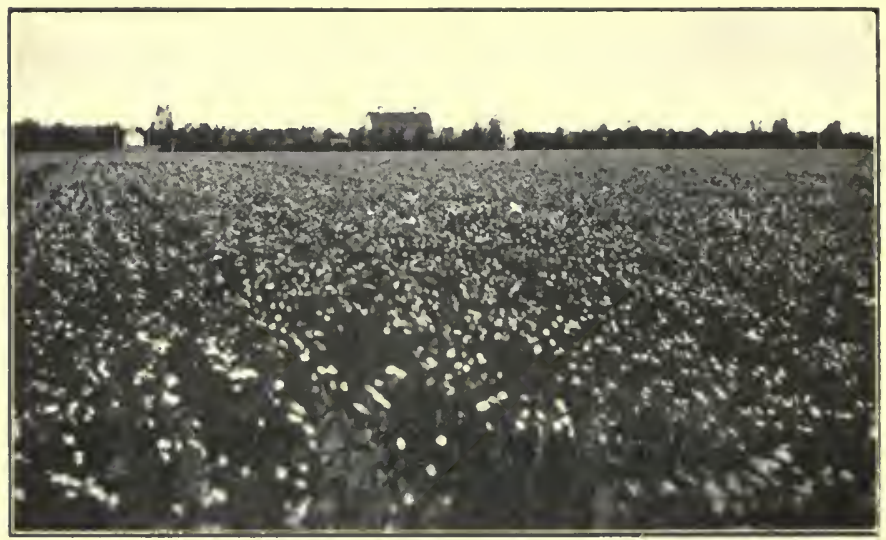

Fig. 33.-Flax in Bloom in Southern Saskatchewan.

As a first crop after breaking, particularly on heavy land, flax is very popular.

resistant. It is, however, a macaroni wheat and has not as yet been grown to any extent as the market demand has been for the eommon wheats. It has done exeeptionally well in western North and South Dakota and eastern Montana and has averaged slightly more per acre than the common spring wheat at Saskatoon. The price is generally slightly lower than for hard red spring. This wheat is deserving of careful trial. Knbanka is at present the best variety of this class of wheat. 
60. Winter Rye.-This is a promising crop for grain, hay and pasture. The relatively low price of rye grain prevents it eompeting suceessfully with wheat where the latter ean be grown satisfactorily. On some types of soil and in some seasons, however, the larger yield of rye is more than sufficient to offset this disadvantage.

61. Spring Rye.-This erop is earlier, hardier and more drought resistant than wheat, but like winter rye the price is relatively low as eompared with that of wheat. On some of the lighter soil types in the dry areas this crop deserves more extensive use.

62. Flax.-As a dry land crop flax deserves greater consideration than it has reeeived in the past, particularly on breaking or sod land, and on heavy land that does not blow. Care should be taken to seeure elean seed, free from disease and to sow thinly on firm soil.

63.-Two-Row Barley.--Most agronomists have heretofore recommended only six-row barleys for Western Canada. The results of eareful tests at Saskatoon and at points in western North Dakota and Montana indieate, however, that some of the two-row sorts are probably to be preferred in the southern parts of western Saskatehewan and eastern Alberta. Hannchen, a tworow but short-strawed variety, has averaged over fifteen per eent. more than the highest yielding six-row varicty at Saskatoon. White Smyrna, a two-row, short-strawed variety is highly reeommended in Montana.

64. Emmer.-This is a wheat the seed of which retains the hull when threshed. It is used in the dry parts of some of the states for horse feed but has not so far been grown mueh in Western Canada. Its usefulness is, therefore, still in doubt. Where oats do not do well on aceount of dry weather it should be carefully tested. $\mathrm{At}$ 


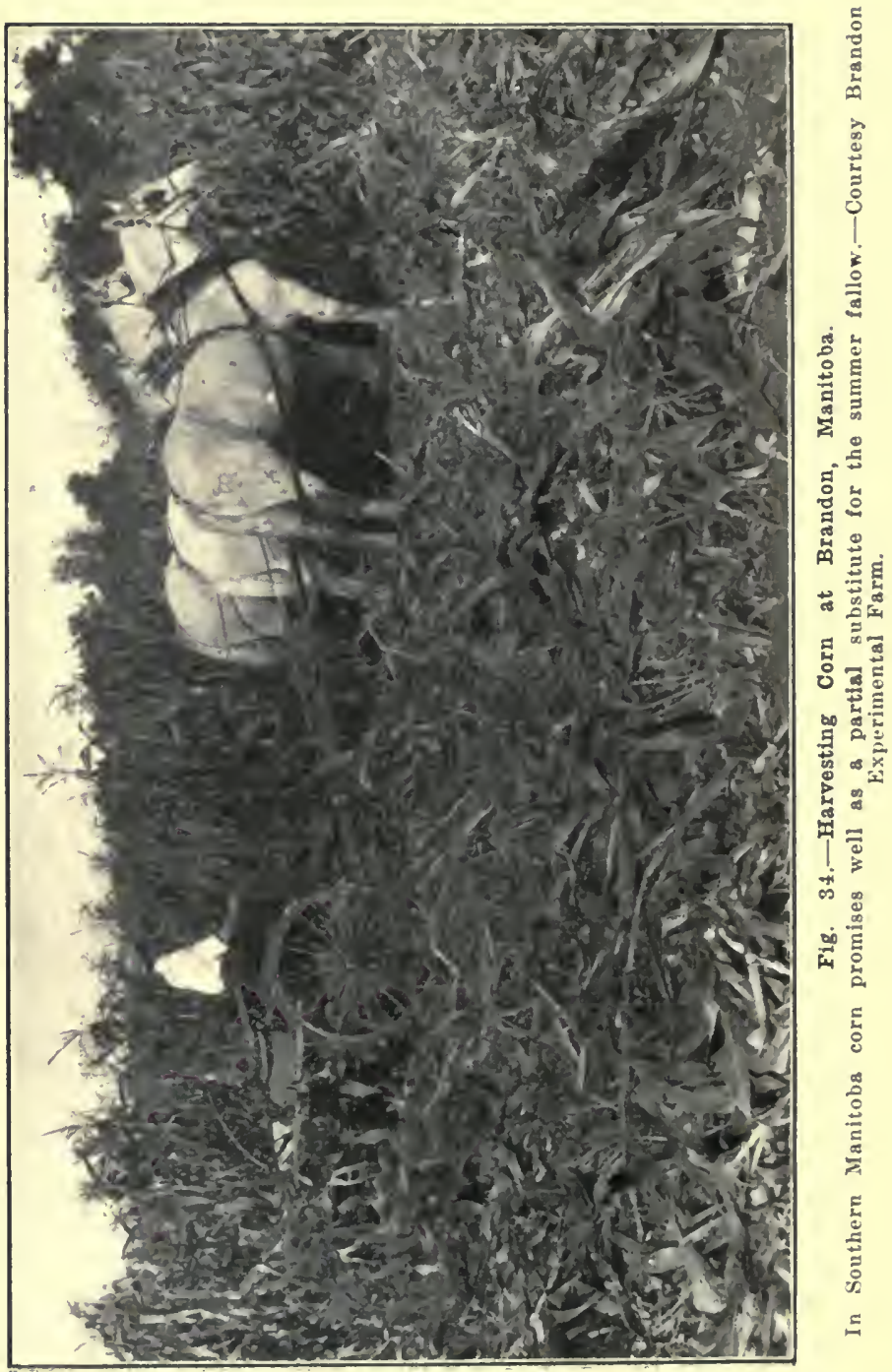


present oats is the commonly used grain for horse feed and where it will produce a larger yield than Emmer is to be preferred.

65. Early 0ats.--In most parts of Western Canada late oats are much more productive than early oats. Is this true in the driest areas? We do not know. The early oats are more productive in some of the states south of us. There is perhaps not much promise in early oats but it is possible that they may avoid the droughts and hot spells in August and yield as well as late oats. Bannel and Vietory are our best late oats, Gold Rain and Ligowo, the best medium late ones, and Daubeney, one of the best early ones.

66. Grasses for Hay and Pasture.--The most drought resistant grasses for the West are Western Rye Grass and Brome Grass. The latter is the best pasture grass, but on aecount of its ereeping underground stems is, like quaek grass, somewhat diffieult to eradicate. While these are the best grasses for the dry parts, it does not follow that they are always profitable ones to grow. Economic and soil eonditions will determine this point. Nevertheless, wherever perennial grasses are required for hay, pasture or soil improvement purposes one or other of these two will be found best. Brome has proven to be more drought resistant than Western Rye Grass.

67. Alfalfa.-This is the best perennial legume for all parts of the western provinees. It does not yield well under dry eonditions and only the hardiest varieties, sueh as "Grimm", will withstand our winters. Under" dry eonditions it yields more when sown thinly in rows and eultivated than when sown broadeast but, of course, the tillage increases the cost. This erop has not been very extensively grown where the precipitation is less 
than sixteen inches, but a small aereage sown in rows for soiling dairy eattle or other stock will be found to be very satisfactory even in the driest parts.

68. Millet.-The millets are grown only on a very small aereage. Their chief use is as "eatch erops" in seasons when the hay erop promises partial failure. They do best in warm, moist seasons. In early spring they make but little headway, and they suffer injury from the first fall frost. They promise most as eatch erops in the dry belt and do best when sown early in June.

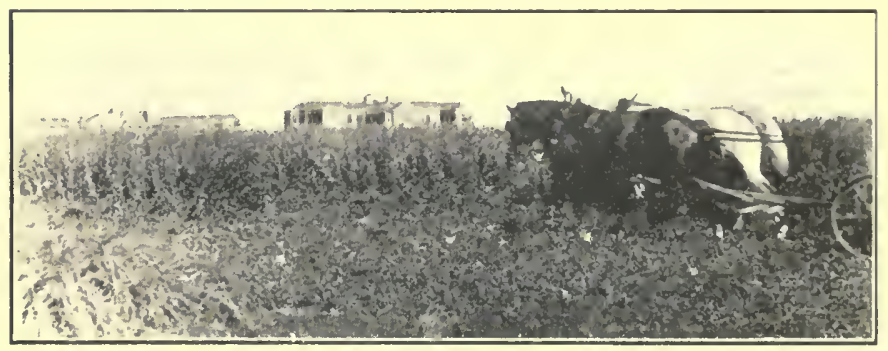

Fig. 35.-Cutting Sweet Clover at Saskatoon, Saskatchewan.

Sweet clover is probably the best biennial legume forage plant for regions having less than sixteen inches of precipitation.

Where oats can be grown satisfactorily for hay it is questionable whether it pays to grow millet.

69. Sweet Clover.-This erop has been little grown as yet by western farmers. It is, however, the most suitable biennial legume for the dry parts, in spite of its coarseness and bitterness. In those areas where the grasses do not yield well, and particularly where the soil is lacking in organic matter or for any reason is in poor tilth, this erop promises much as a forage and a soil improver. Only northern grown strains should be 
used, the tenderer ones from the south often failing to live through our severe winters.

70. Rape.-As late summer and fall pasturage for beef cattle, sheep and swine, rape sown in rows two to three feet part and eultivated has proven an excellent crop.

71. Corn.-The future of corn in the dry belt is quite promising. The yield of grain is low and the value of the forage in the very dry parts is not high in relation to its cost, yet the crop leaves the soil in such a favorable eondition for subsequent grain crops that its more general utilization for fodder, silage, pasture or grain seems almost essential on the lighter, warmer soils in the drier seetions of the southern prairies. It is altogether probable that corn will to a limited extent be used in such areas as a partial substitute for the fallow. Corn ground that has been kept clean has yielded practically as much grain as the fallow at several stations in the semi-arid belt of Canada as well as in the United States.

72. Sunflowers.-This crop has averaged nearly twice as large a yield as corn at Saskatoon during the past six years. Until the last two or three seasons it has not been considered of any value as fodder, but recent trials in Montana, and at Saskatoon as well, indicate that it can be quite satisfactorily ensiled and that the eattle eat it apparently with relish and do well upon it. The sunflower is so produetive and so hardy that if it proves as good a silage erop as the early trials indicate, it will be a safe and probably a profitable erop to grow.

73. Suitable Crop Management Practices.-The erop management practices the farmer in the dry portions of the Canadian West should avoid are late seeding, thick seeding, shallow seeding, late harvesting and the use of varieties that slatter easily or that are too short in the 
straw. Eacl of these in dry seasons and in dry areas is likely to result in lessening the yield.

74. The Time to Sow.-The chief factors in determining the best time to sow are the temperature and moist-

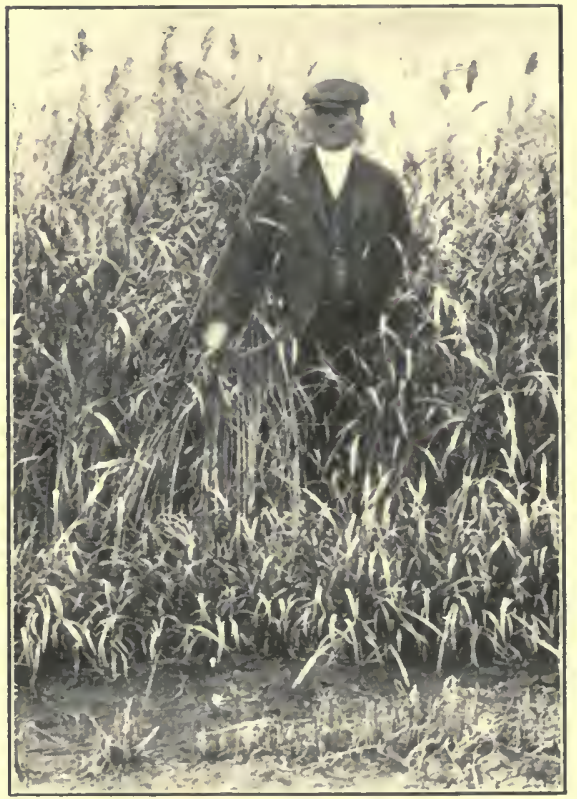

Fig. 36.-Sudan Grass at the Manitoba Agricultural College.

This grass is very productive in warm moist climates, but does not do particularly well in Western Canada, except in very warm, moist seasons.

ure conditions of the soil and the danger from spring and fall frosts. If crops are sown too early they may be injured by late spring frosts or the seeds may die before the seed. lings get above ground. Aside from this danger the seeding of our hardy sereals - wheat, rye, oats and barley - should be done early. If the seeding can be done early enough the moisture from the melting snows will germinate the seed, otherwise in fall or spring plowing the germination may be seriously retarded owing to lack of moisture in the furrow sliee. Climatic and soil conditions vary greatly from season to season and thus influence greatly the time to put in a crop. As 
a general rule, however, the following dates of seeding and planting will be found satisfactory :-

April-15th to 30th-Wheat.

April-25th to May 10th-Peas.

May-1st 10 days-Oats and Carrots.

May-1st 3 weeks-Barley and Spring Rye.

May-10th to 30th-Flax, Potatoes, Mangels and Sivedes.

May-20th to June 10th-Corn, Sunflowers. June-1st 3 weeks-Grasses, Clovers, Alfalfa (Grasses and clovers may be sown with nurse erops at an earlier date).

75. The Amount to Sow.--Thin seeding is a recognized dry farm practice. The drier the district the less serel need be used while the more humid the district anil th: shorter the growing season the greater the quantity that should be sown. Campbell recommends as little as 18 to 20 pounds of winter wheat, 22 to 25 pounds of spring wheat, 20 to 25 pounds of oats, and 35 to 40 pounds of barley per acre in the dry parts of the Western States. The United States Department of Agriculture recommends the following rates for Montana: Wheat, 1 bushel; oats, 1 to $1 \frac{1}{4}$ bushels; barley, 1 to $1 \frac{1}{4}$ bushels; flax, 15 to 20 pounds. For the dry parts of Western Canada rather heavier seedings than those recommended for Montana should be used. Of course, in the more humid seetions of the West considerably heavier seedings are neeessary since a thinly seeded erop takes rather longer to mature and therefore runs a greater risk of injury from fall frost or rust than one sown with more seed. The amounts that have proven best in the average of many tests at Saskatoon which is on the exlge of the driest part are as follows:- Wheat, 1 to $1 \mathrm{r} / 2$ bushels; 
oats, 2 to $3 \mathrm{r} / 2$ bushels; barley, $11 / 4$ to $13 / 4$ bushels; and Hax, 20 to 30 pounds.

76. Sow Into the Moisture.-In dry areas the limiting factor in germination is usually moisture. In this climate very little rain falls in the early spring and if germination is to be assured seeding into the moisture is necessary. Man's part is to prepare the land in such a way that the top of the moist soil is not at too great a depth from the surface.

77. Non-Shattering Varieties.-Very great losses frequently oceur through the shelling of over-ripe or easily

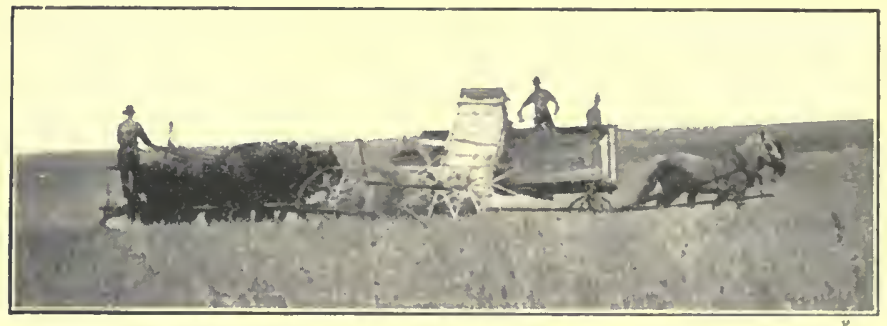

Fig. 36a.-Harvesting Short Wheat with a Header in Southern Alberta.

This method of harvesting has not come into general use in the west, but with short crops in areas of lowest rainfall it has some advantages over the ordinary method of harvesting.

shattered heads as a result of heavy winds at harvest time. In order to lessen this danger two plaetiees may be followed, 1st, use erops that do not shatter readily, and 2 nd, eut before the erop is dead ripe. Among the wheat varieties that shatter least are the Durum types and Marquis. Kubanka seldom shatters even under the worst eonditions while Marquis is known to be more nonshattering than any other of our rommonly grown varieties

78. Short vs. Long Straw.--In dry areas and partien- 
larly in dry seasons the short-strawed varieties of erops are often found to yield less than longer-strawed ones. It is possible that the actual production may not be less but the amount harvested and threshed frequently is. This is probably due to the ineffieiency of our harvesting machinery; the result however is the same. The longer and heavier-strawed varieties probably as a lule use more moisture in manufacturing straw than do the others; nevertheless, it is a fact that in some seasons and on some soils varieties like Red Fife which have a long straw are preferred to varieties like Marquis which have a short straw. 


\section{THE PRINCIPLES OF TILLAGE}

Tillage is the manipulation of the soil by means of implements for the purpose of making a more favorable environment for the growth of useful plants.

79. The Chief Functions of Tillage.-During the long ages in which our best crops have been developed by man as he sought plants to supply food for himself or his domestic animals, the ability possessed by the original wild forms to rustle for themselves has largely been lost. None of our eultivated plants can eompete with the wild forms and continue to exist without the aid of man. The first function of tillage is to furnish the protection these highly developed plants require from the aggressive competition of wild and useless forms.

The first home of the human race was where food plants grew wild and furnished sustenance for man without his care. As population increased and food became searcer these plants were fostered by growing them under more favorable environment. The ancient eivilization of Egypt grew up where the Nile overflowed its banks and watered the thirsty fields, while that of the Orient developed around the coastal plains above which the mountain streams were harnessed and made to water the tilled fields. In the recent history of the race men have grown crops on lands that could not be watered ex- 
eept direetly from the clouds in the form of preeipitation. And in very recent times we have even ventured to grow erops in areas where the rainfall is so light that erop failures sometimes oeeur. In such areas the storage and eonservation of moisture in the soil is essential to erop production, and tillage is the chief means at man's disposal for aeeomplishing it. This constitutes the seeond funetion of tillage.

In our eropping and soil management practices we sometimes ereate in the soil an artificial condition unsuitable to the growth of plant roots. If these practices result in the loss of organic matter, the soil becomes hard and "bakes" easily or blows with the wind. Under sueh conditions tillage has a third function, viz., to improve the tilth or physical eondition of the land as by the pulverizing action of the plow, or the firming action of the packer or the loosening effect of the eultivator.

In growing erops all portions of the plants are not always removed from the land. The stubble at least, generally remains and must be disposed of. Where strawy manure is applied in an endeavor to maintain the organic matter of the soil or for other purposes it too must be gotten out of the way of seeding machinery. The fourth function of tillage is the disposal of this stubble and manure by plowing it under where it will decay.

The last important function of tillage is to prepare a satisfactory seed bed or place for the seed to germinate. It is necessary to leave the surface soil in such condition that when seed is placed in the ground by the seeding implements nsed, it will find in sufficient quantities the factors necessary for germination, viz, moisture, heat and air. 
80.-Objections to Excessive Tillage._-Of all the means at man's disposal for improving soil conditious and fostering the growth of useful plants, tillage is the most expensive, the most practised, usually the most important, and generally the least understood. In this as in other soil management practices the causes of lower returns must first be determined and then the best means of counteracting them put into practice.

To till the ground when it accomplishes no good purpose is useless and expensive and may be harmful. Intensive tillage to control weeds sometimes fails of its purpose because it kceps the surface layer of soil too dry for germination, while the same practice carried to excess in an effort to conserve moisture often defeats the larger purpose of produeing high yields, by putting the soil into a condition in which it will blow. Jethro 'Tull's teaching that "tillage is manure" is true only up to a certain point. Excessive tillage is not only not manure, but it is often useless, always expensive and generally economically unsound.

Since society has developed into groups of people, some doing one class of work and some another, crop growing has become a business and crop production, including tillage, has a business or a cost side to be considered. Tillage costs money; up to a certain point suitable and timely tillage always pays; beyond that point is is not good business. It need hardly be pointerl out that the common error is not in cxcessive tillage, but in its being untimely, unsuitable or inefficient. [i'l problem of tillage is one of timcliness, suitability for tle purpose intended and efficieney of the operation.

81. Implements of Tillage.-The implements used in tillage are of three general classes, (1) plows, (2), soil 
looseners (ineluding weed eutters), and (3) soil firmers. The value of any of the three classes is determined by (1) its efficiency in performing the work desired, (2) its draft, (3) its cost, and (4) its durability. It is not our purpose to discuss the draft or cost or durability of the different types, although these are very important phases of the subject, but to consider very briefly the funetions of the different elasses of tillage implements and their relative suitability for specific purposes.

\section{Plows.}

82. The Function of the Plow.-The function of the plow is to eut off all the roots of plants, to turn the fur-
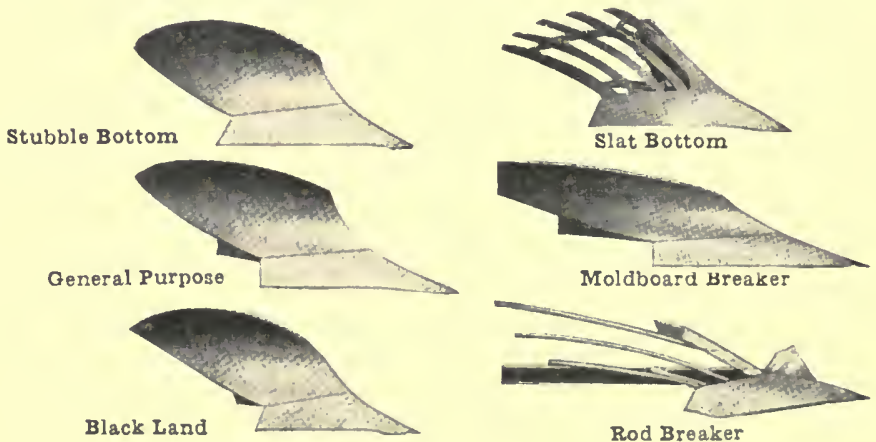

Fig. 37.-Types of Bottoms.

row upside down and completely eover all regetation and litter, to pulverize the soil, to break up a hard subsoil, to leave the surface as smooth as possihle (in this climate) after the operation and to do any or all of these at the lowest possible eost. In plowing, plants are killed by entting off the roots helow the crowns and by 
turning their vegetative parts under the furrow slice. The roots are cut by the sharp share and the vegetation is turned under by the upward sloping, outward eurv-

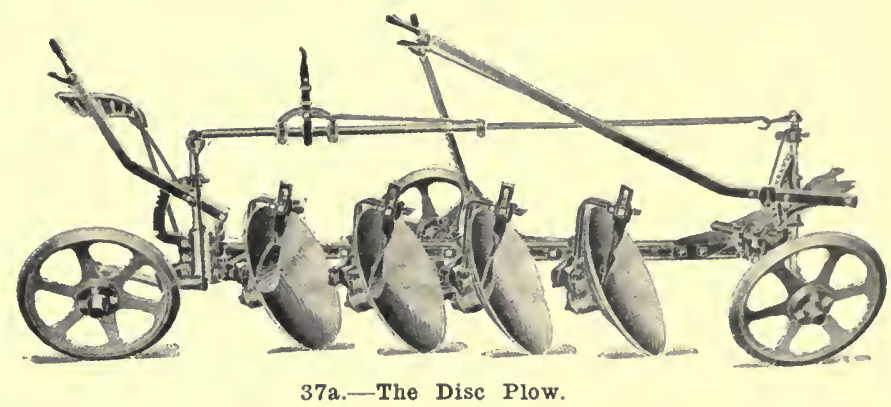

ing mouldboard (Fig 37). The eovering is faciitated by having a straight-edged furrow which the coulter (Fig. $37 \mathrm{C}$ ) makes. The effectiveness of the covering may be increased by the jointer or skim coulter, or by drag chains. The surface litter, of whatever form, is disposed of by thorough covering.

The soil is pulverized least by a long sloping mouldboard (breaker bottom) and most by an abrupt mouldboard (stubble bottom). 'The former is used in sod plowing because it turns a sod furrow better and the draft is lighter. The latter is used in stubble land because it turns the stubble furrow better and pulverizes more. (Fig. 37.).

When it is desired to loosen up heavy subsoil deep plowing may be practised or a subsoil plow or subsoil attachment (Fig. 37B) may follow in the furrow of the ordinary plow.

Kinds of Plows.-There are mouldboard and disc plows; and among the mouldboard types there are sod 
and stubble plows of many patterns. Each of these may be fitted with eoulters, jointers and weed rods or drag chains, and the coulters may be "rolling", "knife"

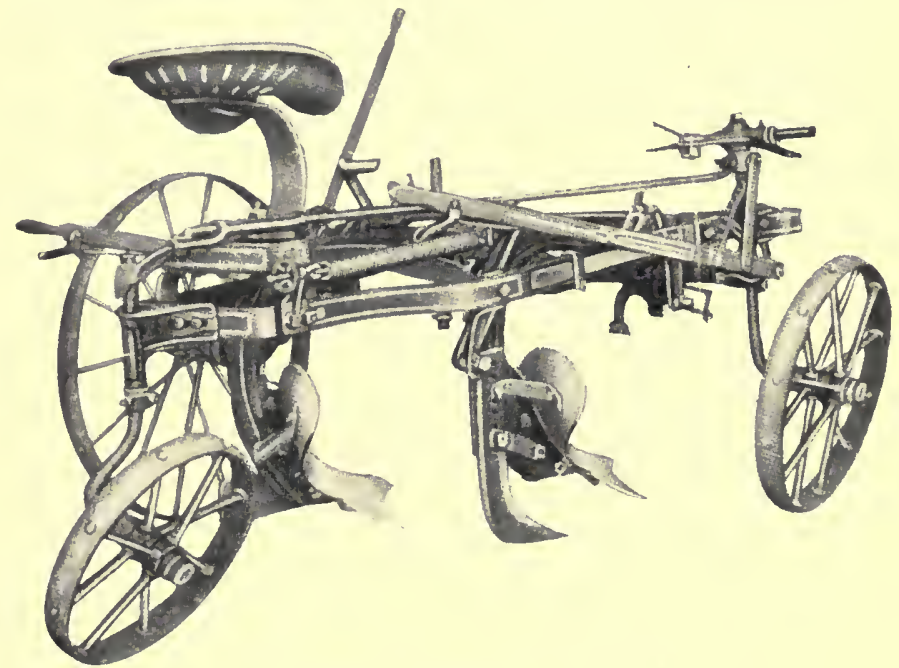

Fig. 37b.-Subsoil Attachment on Mouldboard Plow.

or "fin". But all are plows and all have the same" functions.

The Pulverizing Action of the Mouldboard Plow.Just how the mouldboard plow pulverizes the soil is well illustrated by King (Fig. 38A). If one takes a paper-covered book and bends it abruptly as when about to sean its pages rapidly, it will give him some idea of what happens to the soil as it passes up over the monldboard of a stubble plow. The relative change in position of the particles in the furrow slice is shown by comparing the line 3-3 before the soil is pulverized with the line 1-1 after it has passed the slope of the mouldboard. 
The ideal soil condition for plowing varies with the kind of soil and its moisture content. Soil that is too wet or too dry does not pulverize well, particularly if it is of a heavy type. Such soil is out of "condition" and as a result gives less favorable returns. In autumn in

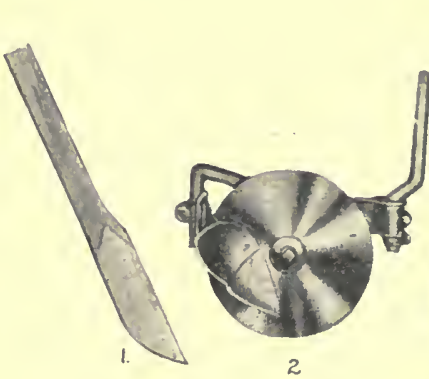

2

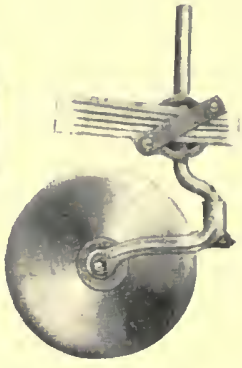

3

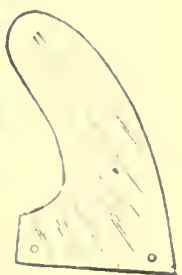

4

Fig. 37c.-Types of Coulters.

1. Blade coulter; 2. Revolving coulter and skimmer; 3 . Revolving coulter; 4. Fin coulter.

the dry parts of Western Canada some of our soils are not in good eondition for plowing. In spring and summer a better eondition usually obtains.

The type of mouldboard to use should be governed by (1) the kind of soil, (2) whether it is in sod or stubble, and (3) its normal moisture eontent. There is a type of mouldboard suitable for almost every soil. The more abrupt the slope the better the scouring quality, but, of course, the greater the draft on aceount of the extra pulverization that is aeeomplished. The common types are the sod bottom (ineluding rods for heavy gumbo), the stubble bottom (including slats for hard scouring soil) and the general purpose bottoms. These different bottoms are generally interchangeable with each other on the same make and size of plow. 


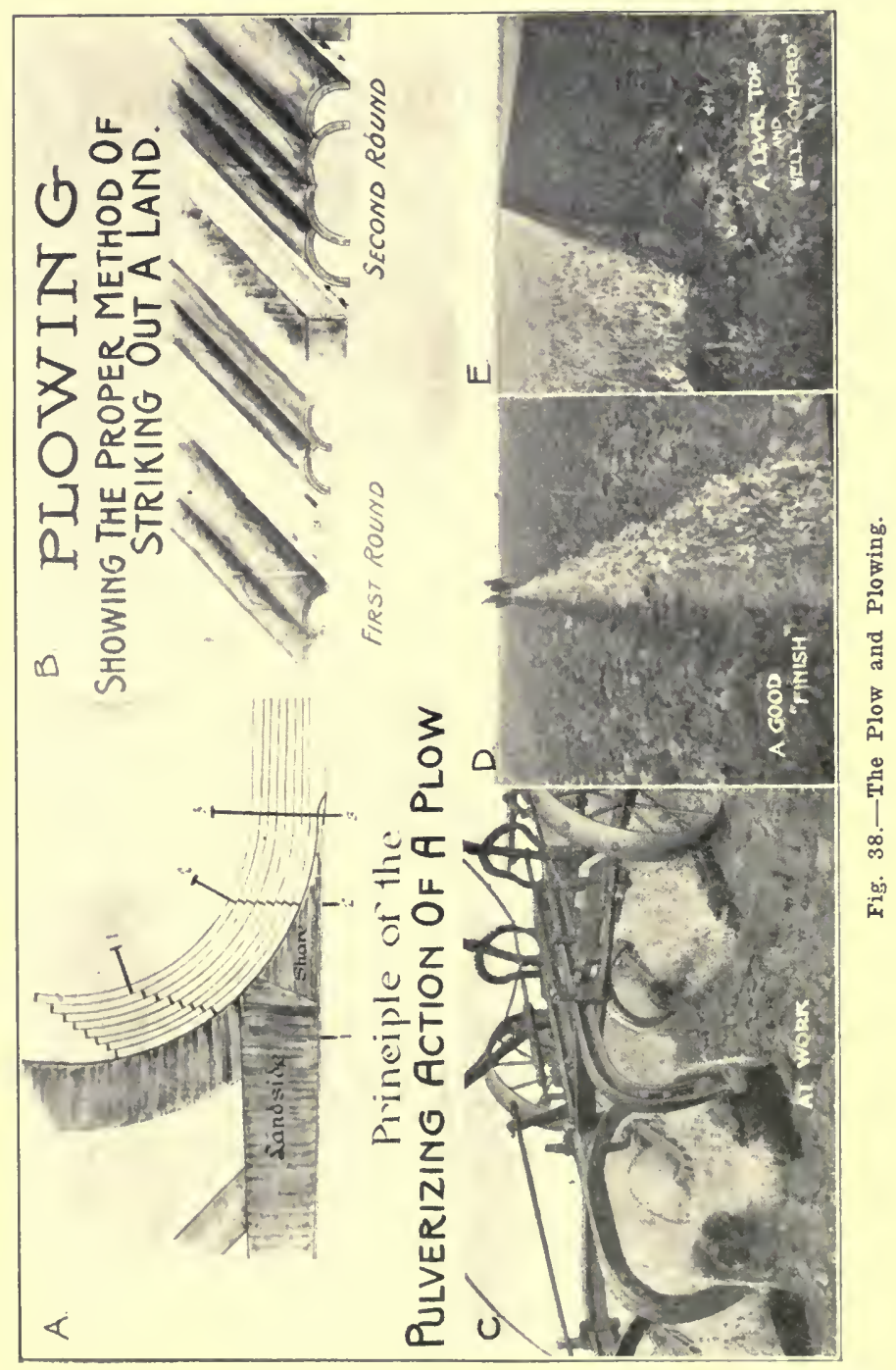


In some sticky soils the ordinary mouldboard plow will not "clean", and in breaking the prairie, plows laving rods (Fig. 37) instead of sheet mouldboards are used. These elean better and result in less friction and therefore lighter draft than the sheet mouldboard type and are the best to use in breaking "loose top" and some other stieky soils.

83. The Disc Plow.-On stubble fields in heavy land where the mouldboard plow will not elean, the dise plow (Fig. 37A) is used. This does not eut grass roots nor cover weeds, nor pulverize the soil as well as a mouldboard plow where the latter will clean. Where a mouldboard plow will not elean it is not satisfactory for any of these purposes. It requires more frequent sharpening than the dise, and it pulls harder; but where it can be used at all satisfactorily the mouldboard type is generally to be preferred over a dise plow.

84. Coulters.-Coulters are used on mouldboard plows to ent the edge of the furrow, thus at once lessening the draft and making it possible to do a better job of eutting roots and eovering rubbish. There are different kinds of coulters such as "fin", "knife", "rolling coulter" and "skim coulter" or "jointer". The rolling coulter is mostly used in the West. It should be set about half an inch outside the line of the landside and should eut at least one-third the depth of the furrow. In trashy ground it should be set well forward to give more elearanee, while in stony ground it should be set well down as well as ahead. The skim eoulter does good work under some conditions in helping to cover weeds. Combination skim and rolling eoulters are very eommon as are also those of the fin and knife type. (Fig. 37C). 


\section{Soli, Looseners.}

Among the soil looseners-and these include intertilling machines-are those having dises, eutting blades or stirring points. Those having revolving dises are known as dise harrows, while most of those having stirring points are ealled drag harrows. Those having cutting blades may have spring teeth, "duck" feet, or long slanting knives and are generally spoken of as
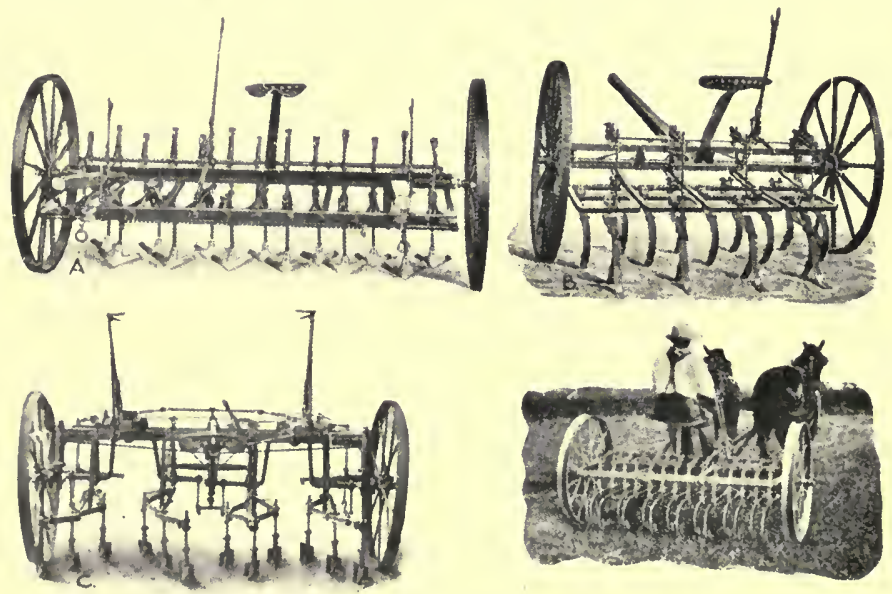

Fig. 39.-Types of Cultivators.

(a) Wide-bladed or duck-foot cultivator; (b) Spring-tooth cultivator; (c) Narrow-bladed two-row intertillage cultivator; (d) Alfalfa renovator at work.

(nltivators. But all are soil looseners and their chief functions are to eontrol weed growth and to loosen the surface soil in order to kill weeds or make a soil mulch or admit air.

85. Cultivators.-The eultivators have eutting points of various wilths and designs. The wide bladed or "(luck footed" types (Fig. 39.1) are chiefly used to cut 
off weeds below the surface and the narrow blated types (Figs. 39B, 39D) to loosen up hard ground or to dig out the erceping roots of such plants as quack grass.

A type of cultivator developed for stiring the soil and entting weeds between rows of plants like potatoes and corn and known as an intertillage cultivator, differs from the others in form of carriage but not in function nor in mode of action. (Fig. 39C.).

86. Disc Harrows.-The dise harrow (Fig. 40 A. \& B.) is used chiefly to loosen up the surface of soddy ground like breaking, or to cultivate the surface of stubble fields to eonserve moisture or kill weeds, or to form a seed bed on stubble or plowed land. In view of its peculiar structure it ridges the land if "lapping half" is not practised or a double dise used. The alfalfa renovator (Fig. 40D) is especially designed (1) to dig the fibrous rooted grasses out of alfalfa and (2) to loosen up the surface of alfalfa fields without too scrious injury to the plant roots.

On account of its rolling action the disc harrow can be used under many conditions. In the TVest its chief function has been working down the virgin prairie sod. The standard dise harrow has either full round clises or cutaway blades usually 16 inches in diameter, sixteen in number and spaced six inches apart. This is the fourhorse size. The sixteen-inch dises rotate at greater speed than the larger ones and thus pulverize the ground more; they have less bearing surface on their edges and therefore more penetration.

Single disc harrows should have one lever for each gang. When "lapping over", i.e., allowing the dise to extend half way over the work of the previous round, is practised the ground is left level and not ridged. The 
gang working on the once disked ground finds a different resistance from the one working on the undisked ground, hence does not "balance". By setting the gang on the loose soil at a different angle the imple-

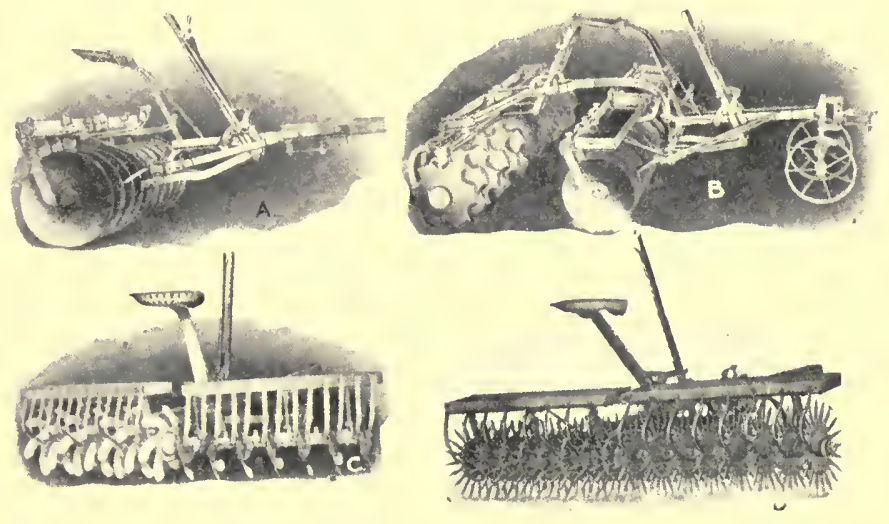

Fig. 40.-Types of Disc Harrow.

(a) Full bladed disc; (b) Double disc; (c) Spade harrow; (d) Spiked disc or alfalfa renovator.

ment may be made to pull straight and thus do better work. In hillside work the marhine has a tendency to rrowd downhill. This ean be overcome when levers are provided for adjusting each gang separately.

'The full bladed and entaway dises are the two most rommon types. The former does better work although exeellent results have been obtained from a double disc with full blades on the front and "utaway blades on the rear.

In reeent years a dise attachment for seeders has been largely used. 'The "single dise" drill (Fig. 43C) is a dise harrow which cultivates the soil to some extent as well ats sows the seerl. The double lise on the other hand 
is not a harrow or eultivator but only a seeder. (Fig. 43D).

87. Drag or Smoothing Harrows.-The purpose of the drag or suroothing harrow is to prepare a level and uniform surface after other kinds of tillage, or to destroy young weeds by exposing their roots to the sun and air, or to form a muleh on the surface to eonserve moisture or to aid in eovering the seed after sowing. The drag harrow may be heavy or light, have wooden or steel frames and the teeth may be stationary (Fig. 41A) or

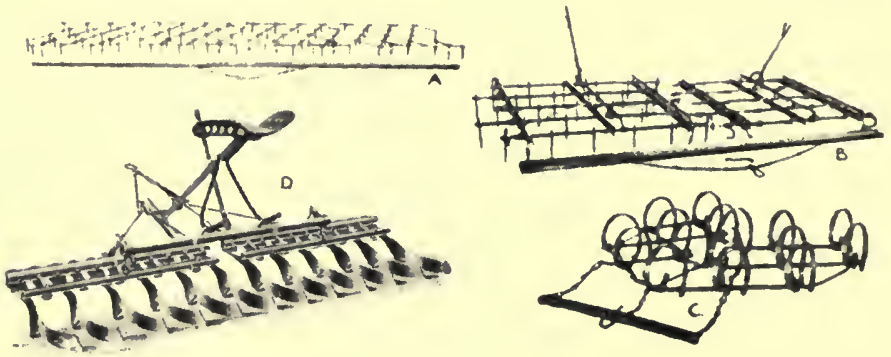

Fig. 41.-Types of Harrows.

(a) Steel harrow; (b) Adjustable harrow; (c) Spring tooth harrow; (d) Acme harrow.

adjustable (Fig. 41B). The light lever harrow with teeth sloping slightly backward is frequently used in the growing erop of grain, eorn or potatoes for killing small weeds.

'The spring tooth harrow (Fig. 41C) has the same function as the spring tooth cultivator. It is lighter in draft but less efficient.

The acme harlow (Fig. 41D) smooths the surface, ents small weeds and forms a muleh, but it is not well adapted to general use under average farm eonditions. 
SOIL FirMERS.

Among the implements that firm the soil and thus erush lumps or lessen the air spaces, or pack the soil about the seed, are the home-made planker or serubber and the press attaehment for drills. All of these are soil firmers or elod erushers of different degrees of effieiency and of vastly different cost. One may fit eertain specific soil conditions better than another. Each has a place in the economy of some particular farm and most

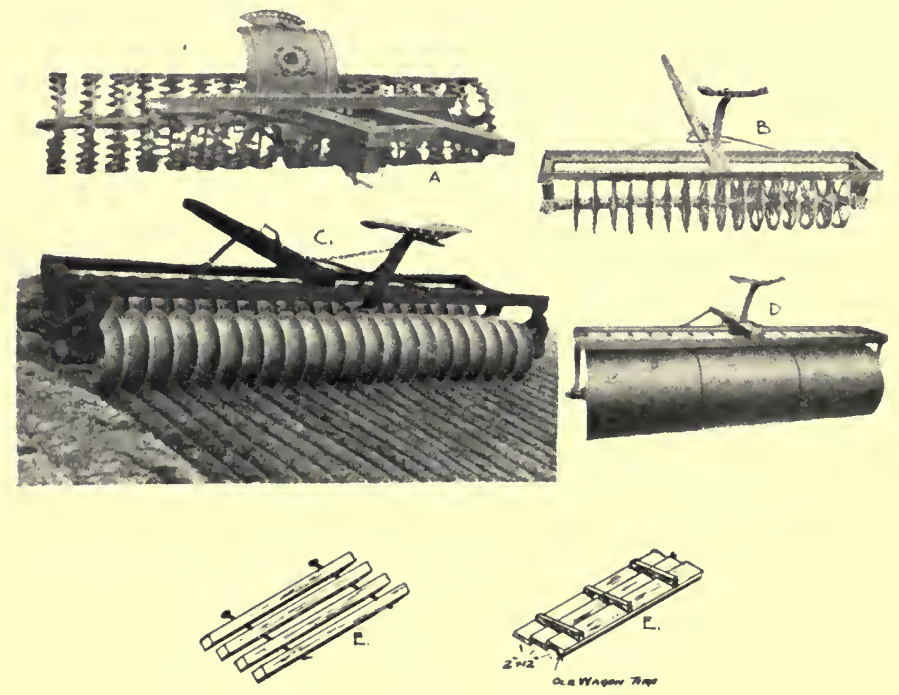

Fig. 42.-Types of Soil Firmers.

(a) Surface packer or pulverizer; (b) Sulsurface packer; (c) Culti. packer; (d) Smooth roller; (e) Float and planker.

of them when used intelligently will prove a profitable investment. Yet no one is absolutely essential on any farm. The work of firming the soil ean be accomplished 
with other implements though generally not so efficiently as with the machines designed for that purpose.

There are six more or less distinct types of soil firmers, (1) the surface packers, "pulverizers" or clocl erushers (Fig. 42 $\Lambda$ ), (2) the sub-surface packers (Fig. 42B), (3) the so-called "culti-packer" (Fig. 4:C), (4) the smooth roller (Fig. 42D), (J) floats and plankers (Fig. 42E) and (6) the press attachments for grain drills. (Fig. 43A).

88. The Purpose of Soil Firmers.-The ehicf function of all six types of soil firmers is to aid in facilitating the movement of moisture from the subsoil to the furrow sliee or in bringing the moisture of the soil into eloser eontact with the seed or roots of plants. On "breaking", any one of the first four types may be used to press the furrow slice against the subsoil; the surface and subsurfaee packers are generally considered best but the home-made float or planker requires less power and is eheaper. After stubble plowing one or other of the packers is usually preferred. In the drier parts the subsurfaee packer is commonly used and in other areas on late plowed fallows and on fall and spring plowing it is preferred by some. It is, however, less of a general purpose packer, and is in reality less used in the West than the surface or eorrugated packer. The "enltipacker" is an excellent implement to pack the soil about the seed after seeding, but for any other purpose it is not considered to be superior to the surface packer.

The plankers are chiefly used as levellers, but on breaking their value is in flattening out the plowed furrows. They are sometintes used on stubble fields after seeding where some additional soil over the seed is de- 
sirable and where, owing to the stubble, harrows do not work satisfactorily.

The smooth roller is but little used in the West. Its function is similar to that of the surface packer but it is less desirable than the latter since it leaves the surface' too fine and with too little mulch and in a condition favorable to blowing. The surface packer leaves a granular mulch and a surface that is not so likely to blow.

89. Drills as Tillage Machines.-The chief function of a seed drill is to place the seed in the soil where it will get

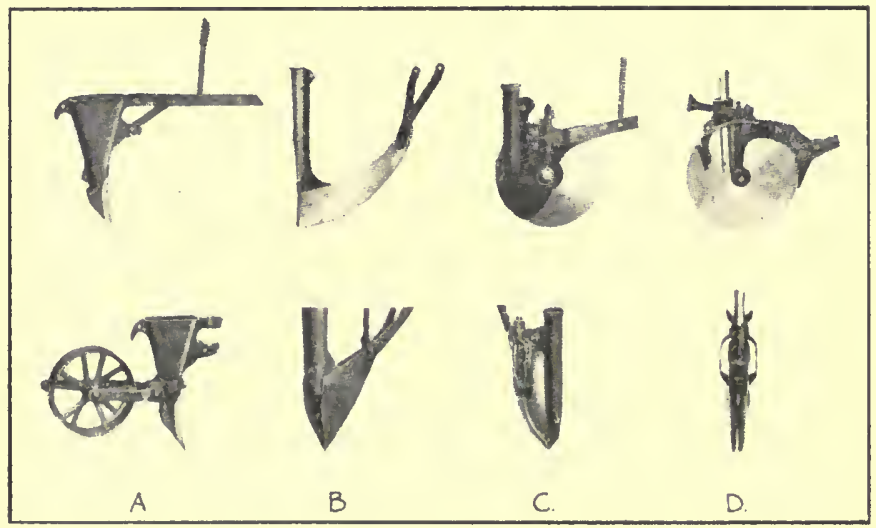

Fig. 43.-Types of Drills.

(a) Hoe drill with press attachment; (b) Shoe drill; (c) Single dise drill; (d) Double disc drill.

the moisture, heat and air conditions necessary for growtl. Its efficiency as a seeder, aside from its mechanical faults or virtues is determined by the depth it will place the seed and the firmuess of the soil about the seed after the operation. There are four chief types of 
drills, the "shoe" drill, the "hoe" drill, the "single dise" and the "double dise". (Fig. 43).

The shoe drill (Fig. 43B) can hardly be ealled a tillage implement. 'The hoe drill (Fig. 43A) is to a slight degree a eultivator of the narrow tooth type. The single dise drill (Fig. 43C) is not only a drill but a dise harrow as well, of rather low effieieney, while the double disc is a drill only. (Fig. 43D).

Where some eultivation is needed, such as on some unplowed stubble fields, the single dise is perhaps best. On soils that are well prepared and not too hard and where drifting is feared the old hoe or the shoe drill are quite satisfactory, particularly on light soils. Where soils are well prepared, yet quite firm, the double dise is probably the best to use.

The shoe and hoe drills pull easier and generally require less repairs than the dises but on all exeept light soil or well prepared land they are not at present as popular as the dises.

90. Press Drills.-The press attachment is a paeker and perhaps the most effieient one from the point of view of the seed. It packs the ground where it needs paeking at the time it needs it, and leaves unpacked the portion that is best left loose. But the press drill as at present construeted is costly, heavy to pull, somewliat diffieult to operate, partieularly in sticky soil, and is likely, as a rule, to require more repairs than most other types of drill. It is eoming into quite general use on soils that drift and is often found on medium type soils in the dry belt. (Fig. 43B). 


\section{CHAP'TER VII.}

\section{BREAKING THE VIRGIN PRAIRIE}

"Breaking" is the western term for the first plowing of the native prairie land. It is the first tillage operation undertaken by the settler in order to make the raw prairie sod suitable for the growing of eultivated crops. The breaking is usually followed by more or less tillage the same season and may include a seeond plowing, which is spoken of as "backsetting". When this seeond plowing is not given the surface tillage usually consists of packing or "planking", disking and harrowing. If the intention is to backset, the breaking is done shallow, but if not, it is the eustom to break more deeply.

When the breaking is done in the spring, it is sometimes sown to grain the same year. In the dry districts this practice frequently results in partial or complete failure but in wet years or in the more humid parts fair yields are sometimes secured. The plan usmally followed is to leave the land without a crop until the next season.

In the early days, when the fillage of prairie sod was not so well mulerstood, new breaking was not expected to give a good coop. Even now new settlers frequently fail to get good returus from their first efforts. There is, however, no good reason why the first crop should not be an exeellont one in the arerage year. 
91. Why We Till Prairie Sod.-The function of tilling prairie sod in semi-arid elimates is threefold: -

1. 'To store and conserve moisture in the soil.

2 . 'To kill the native vegetation, and

3. To prepare a suitable seed bed.

92. How Moisture is Stored and Conserved in New Land. - The storage and conservation of moisture is necessary

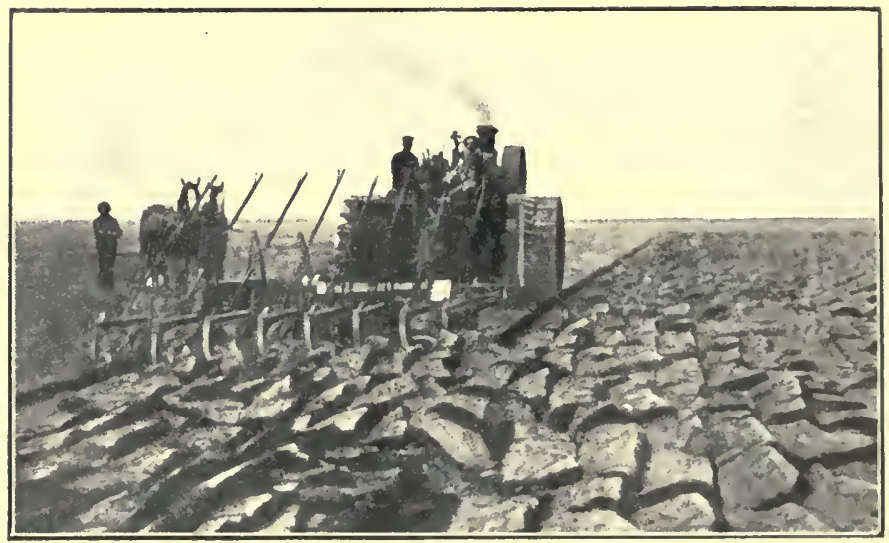

Fig. 44.-Breaking with Tractor.

No skips or misses but land too dry for a smooth job.-Courtesy Dominion Experimental Farms.

before profitable crops can be raised on new land. This is aecomplished by (1) killing the native regetation early in the growing season, (2) by preventing the "runoff", and (3) by preventing the exeessive drying out of the furrow slice.

All prairie land is eovered with a growth of grass and uther plants native to the distriet. These use up moisture in just as large quantities as weeds or domestie crops. (See Sec. 168). Most of them make their greatest 
growth early in the season, hence the sooner the plowing is done the greater the amount of water conserved.

Native prairie does not readily take in all the water that falls upon it especially if the land is rolling or hilly. Plowed land on the other hand absorbs water more readily than unplowed land. Breaking early in the rainy season gives, therefore, greater opportunity for the soil to absorb moisture and breaking crosswise of the slopes, if possible and practicable, faeilitates the absorption of a greater part of the rum-off from melting snow the next spring.

The loss of moisture by evaporation from the furrow slice and from the subsoil of a freshly broken field is very great for the reason that, not only the top of the furrow, but generally its sides and often its bottom, and the furrow bottom as well, are exposed to the drying influenee of the wind. This loss of moisture is lessened by (1) turning the furrow perfeetly flat, (2) bringing it against the subsoil with a packer or planker, and (3) disking to fill in the eracks between the furrows as soon as the latter are suffieiently decayed to permit of this being done without turning up unrotted sods.

Plowing the prairie sod results in partial or eomplete killing of the native plants and in making the soil receptive to rains, thus at onee preventing loss by transpiration and by rum-off. Then, by parking and disking the loss of moisture by evaporation is lessened and more is conserved for the use of the sulsequent crop. The longer the disking is left undone after breaking the better the land will "work up" but the sooner the loose layer can be ereated on the surface the more moisture there will be saved. 
93. Killing the Native Prairie Plants.-The native vegetation consists chiefly of grasses and various shrubs, such as rose bushes and wolf willow. Some of these plants are fibrous-rooted while others, such as native

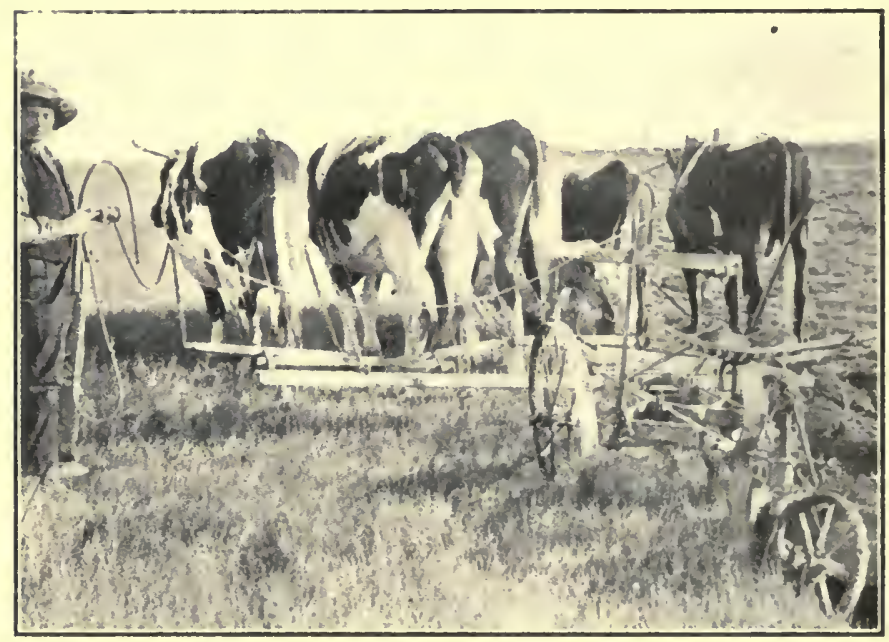

Fig. 45.-Breaking with Oxen.

Not an unfamiliar sight in the early days of land settlement in the west.

quaek and the rose bushes have underground stems or "creeping roots". These plants can be killed ouly by plowing. Fibrous-rooted plants ean be killed by onee plowing if followed by reasonable surface cultivation. Creeping-rooted ones are less easily disposed of, and in order to eompleteley eradicate them it is neeessary either to break and backset or to break in a dry time and let the furrow slice dry out before it is surfaee-cultivated.

It is obvious, therefore, that on land that is to be plowed only once, the best practice for conserving moisture is not the most efficient for killing the ereep- 
ing-rooted grasses; plowing once will be successful in the latter respeet only in proportion to the dryness of the season. In other words if the season is a wet one, the perennial plants are not likely to be eradicated by plowing once. It is apparent, therefore, that the specific practices to be followed must be determined by the local and seasonal conditions of soil and climate.

It is, however, always a good policy to plan to get rid of crecping-rooted plants the year the breaking is done

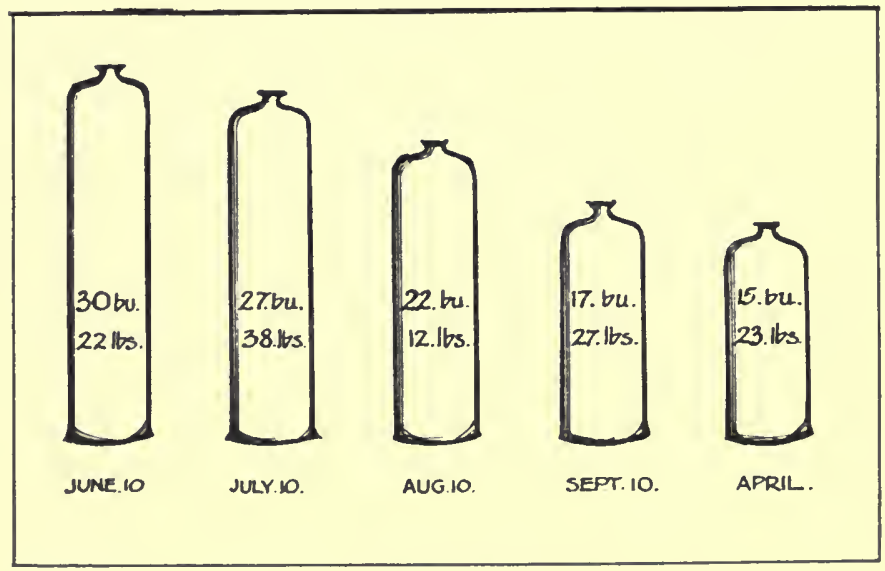

Fig. 46.-June Breaking Pays in the Dry Belt.

This chart illustrates the average yield secured on breaking done during June, Ju!y, August and September and the following spring on a clay loain soil in West Central Saskatchewan.

if at all practicable, otherwise they will be a drain on the productiveness of the land and in any ease will have to be eradicated later at probably an added cost. As a rule if ereeping-rooted plants are present and known to be difficult to eradicate, breaking and backsetting is to be recommended; if they are not present or are found in such small numbers that they are not difficult to control, 
deep breaking with adequate eultivation will prove a somewhat less expensive metlod of preparing sod land, and in many places, especially in dry areas, equally effective.

Plowing late in June or early in July, rather than at an earlier date, favors the eradication of all ereepingrooted plants for the double reason that subsequent to these dates the rainfall is generally less and the vitality of the plants lower than before.

For the same reason plowing once is more likely to be adequate in dry areas than in wet ones, and plowing twice more advisable in moist areas than in dry. If a long breaking season is contemplated a practice vory much to be eommended is to break shallow up to the 1ith or 20 th of June (in the dry parts) and after that date break deeply. The carly shallow breaking may then be backset after the sod decays, and the later deeper breaking may be prepared by disking. Land earrying a tall or dense growth of serub eannot be satisfactorily plower a second time in the same season.

94. Preparation of the Seed Bed.-- Ifter killing the lative: plants of the prairie and storing a supply of moisture for the erop, it is important that the soil be left $n$ such condition that the requirements of germina1.ion and future growth may be easily and abundantly. supplied to the seeds and roots of the rrop. 'T'o insure that these requirements he met it is necessary (1) that the furrow slice be firmly in contact with the subsoil so that the subsoil moisture may not be prevented firom moving to the seed and roots of the (a)op; (2) that the soil be prepared in such a mamner that suffirient moisture for germination will be within one to three inches of the surface so that too deep seoding may not be neces- 
sary, and (3) that a mellow layer of soil be formed on the surface to function efficiently as a seed eovering alter the passage of the drill. The use of the packer, dise and harrow in the order mentioned and at the right time is the best way to aecomplish the desired results. Ordinarily, the land is firmed down by a packer or plank:!r soon after plowing, disked as soon as the sod has pritialiy rotter and then harrowed to prepare a uniform and levis surface.

95. Some Desirable Practices in "Breaking" Prairie Sod. -Most of the practices to be diseussed under this heading might easily be inferred from what has already been

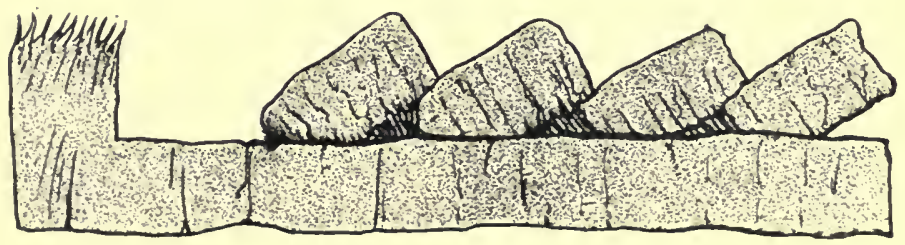

Fig. 47.-Improper Breaking for Dry Areas.

The furrow slice instead of lying on the corner of its neighbor should lie flat.

said. In diseussing them it should be kept in mind that a practice that is best in one distriet may not be good in another. Each so-ealled "desirable" practice should therefore be eonsidered in its relation to the needs of the situation, the presence of ereeping-rooted plants and the average rainfall being the ehief determining factor.

96. Break Early to Obtain Maximum Yields.-The decrease in yield of wheat on breaking done after the tenth of June at Saskatoon has been found to average one bushel per aere per week. In more humid districts the decrease will probably be less and in drier divirirts greater than this figure. The following table gives the 
average acre yield of different crops on breaking done at different periods throughout the year.

TABL: XVI.-Showing the influence of time of breaking on the yield of different crops in Saskatoon-average of three year.s test in crop seasons of 1915, '16 and '17.

Wheat Barley Flax Potatoes Corn Date of breaking bus. lbs. bus. lbs. bus. lbs. bus. lbs. lbs.

\begin{tabular}{llllllll}
\hline June $10 \ldots \ldots \ldots \ldots$ & $30-22$ & $39-33$ & $19-27$ & $215-26$ & 30819 \\
July $10 \ldots \ldots \ldots \ldots$ & $27-38$ & $36-30$ & $18-24$ & $210-16$ & 30239 \\
August $10 \ldots \ldots \ldots$ & $22-12$ & $26-29$ & $13-20$ & $157-22$ & 22608 \\
September $10 \ldots \ldots$ & $17-27$ & $22-13$ & $13-20$ & $155-38$ & 20727 \\
Early Spring* $\ldots \ldots$ & $15-23$ & $19-44$ & $13-43$ & $143-28$ & 18780
\end{tabular}

There are two fundamental reasons why early breaking inereases the yield, the first being an increase in the soil moisture content and the second, a better state of soil tilth. The inerease in soil moisture is due chiefly to the fact that native plants have been prevented from using it up and also to the greater facility with which the eultivated land is able to absorb moisture and prevent its evaporation. The better soil tilth is due to the fact that land that is broken early has a much better ehance to disintegrate since it has the neeessary moisture to promote deeay and is exposed to the action of the weathei for a greater length of time.

97. Plow all the Land.-Good plowing when breaking prairie sod is probably more important than any other phase of the breaking operations. Pooply plowed breaking does not kill all the grass with the result that no erop is produced where the "skips" oecur, and in the seeond and often in subsequent crops this grass increass and seriously lessens the yield. Poor breaking is the chief reason for grass in stubble fields which in turn is one of the chief causes of low yields on such land.

* Refers to season the erojs is sown. The other dates refer to the previous year. 
98. Turn the Furrow 0ver Flat.-The furrow slice should be turned over flat on the furrow bottom, otherwise the sod does not rot satisfactorily and the furrow slice itself dries out too much. It has been observed

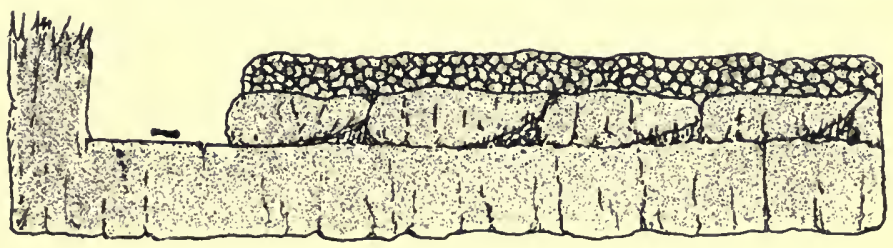

Fig 48.--Improper Breaking-after Discing.

Showing the loose, open spaces under the furrow slice which are so undesirable in dry areas.

that where good plowing is done and the furrow slice turned down flat, rather than on edge, the sod rots better and larger returns are secured.

99. Pack or Plank after Breaking.--For the same reason that sod or prairie land should be turned over flat, it should also be pressed firmly against the subsurface soil. For this purpose the land packer or the home-made planker give excellent results. In the dry summers of 1914 and 1917 the only breaking on which the sod thoroughly rotted was that which had been well packed. In a wet season the necessity for packing is not so great.

On land that contains some creeping-rooted grasses but which it is not considered necessary to backset the same scason, and in low-lying areas particularly, it is sometimes advisable to leave the breaking unpacked for a few days to permit the furrow slice to dry out and thus aid in killing the grass.

100. Disk Deep Breaking as soon as Possible after it can be done without Turning up Sods.-Moisture evaporates rapidly from the smooth surface and sides and from the 
bottom of the sod furrow. As soon as disking can conveniently be done without turning up unrotted sods, it should not be delayed. On some soils it ean be done very soon after breaking, but on other's this operation often lias to be left until the sod is at least partially decayed. In practice it is msmally found advisable to break while

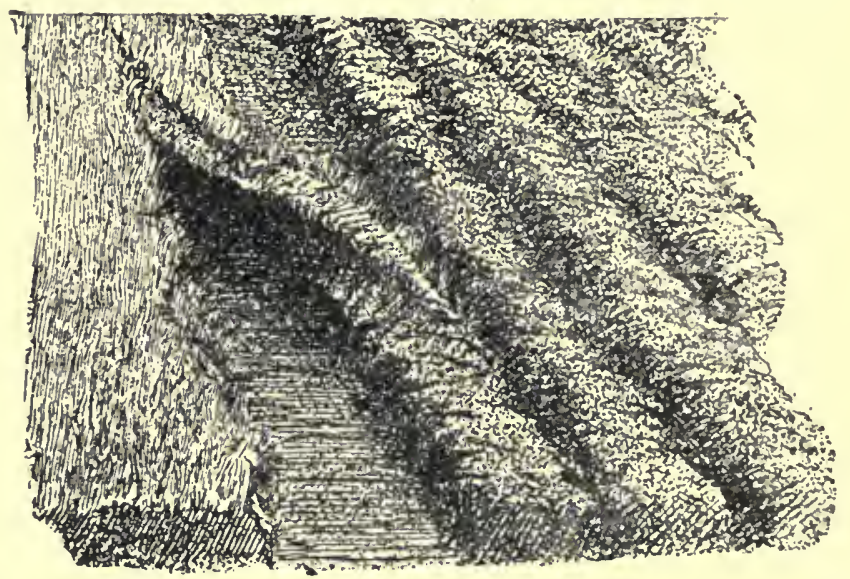

Fig. 49.-In Breaking the Furrow Slice Should be Turned over Flat.

the soil is moist and the land can be easily and quickly plowed, and to do the disking later when it is difficult or impossible to plow.

101. Cultivate Sufficiently during the Season to Prevent the Growth of Native Plants.-If prairie land is broken and the surface left uncultivated a considerable amonut of moisture is lost as a result of the drying effect of thr wind. At the same time if any of the native plants still persist they not only establish themiselves in the soil but they pump out very lalge quantities of water. The use of the dises and harrows often enough to prevent the 
growth of these plants and to kcep the soil from drying out is essential after the sod has deeayed suffieiently to permit these implements to do good work.

\section{To Control Creeping-Rooted Grasses Break Early} and Backset.-It has been pointed out that the primary object of tilling prairie land is to kill the native vegetation and increase the moisture eontent of the soil. Unfortunately, the same practices do not always result in aceomplishing both purposes, since the drying out of the furrow slice is the most effectual way to kill ereepingrooted grasses. Under most eonditions and in most years both of these objects ean be attained by breaking and backsetting. Single plowing ean be depended upon to eradieate ereeping-rooted grasses only if the district is dry or if it is a dry year in a more moist area, or if it is done late.

The first erop after breaking and backsetting is often not muel larger than the first crop after deep breaking that has been surface eultivated, but the second and later erops are invariably better from the twice-plowed land. In the year 1913, the seeond erop of wheat on land that was broken and backset yielded 14 bushels, 36 pounds of wheat per acre, while the second crop on adjoining land that had been broken deep and surfic." eultivated was bnt 4 bushels, 11 pounds per acre. The difference was dne altogether to the presence of native quack grass in the once-plowed breaking. Single breaking and disking is less expensive than breaking and backsetting, and when done in good time on soils free from quack and sweet grass often gives als good results. Barksetting in our opinion is alvisalyle only in areas or on soils where once-plowing does not ordinarily kill thi: grass. 
103. Don't Backset if Sod has not Rotted.-In very dry summers it is more difficult to backset and less diffieult to kill the prairie grasses than in wet summers. In 1914, as in some other dry years, it was physically impossible

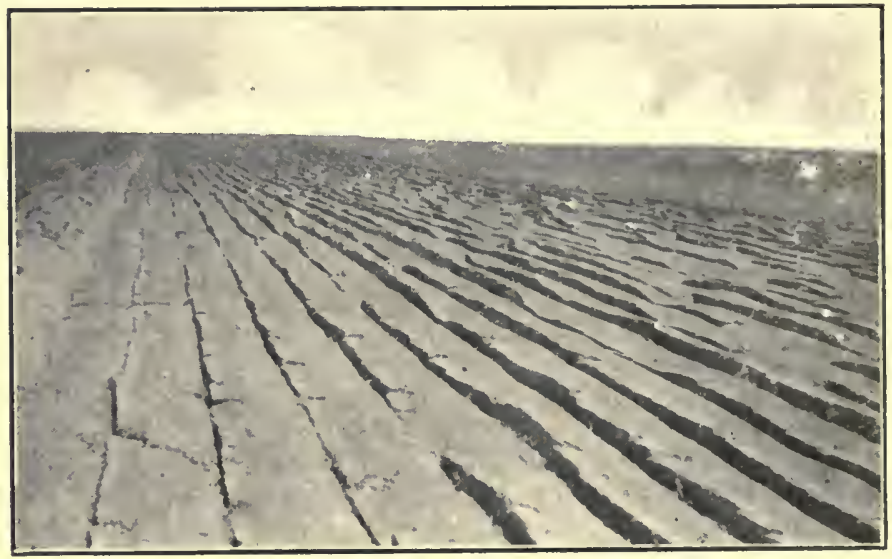

Fig. 50.-A Good Job of Breaking on Medium Light Soll.

in many areas to baekset any breaking exeept that which had been done early and well packed down. In addition to this difficulty, it was noticed that even where backsetting was done the unrotted sod produced a very unsuitable seed bed and one that required an unreasonable amount of surface tillage before it was eonsidered satisfactory.

104. Land Intended to be Backset Should be Broken Shallow; that not to be Backset, Deeper.-Deep breaking ('ontrols native plants better than shallow breaking but it cannot be backset satisfactorily. If it is the intention to backset, it is therefore advisable to break shallow. In some parts it is a fixed praetice to plow shallow in the 
early part of the breaking season and deeper at the latter end. The early breaking ean then be backset after the breaking season is over. "Shallow" and "deep" are used here as relative terms. A depth of two to four inehes is generally considered shallow breaking and four to six inches deep breaking. "Baeksetting" should usually be about two inehes deeper than "breaking".

105. Harrow and Pack Backsetting.-The moisture stored in the subsoil of plowed land must be kept available to the seed and plant roots. In order that this condition may obtain, firming the loose soil after baeksetting is advisable. The general praetice in the early days was to harrow sueh land thoroughly. It is now

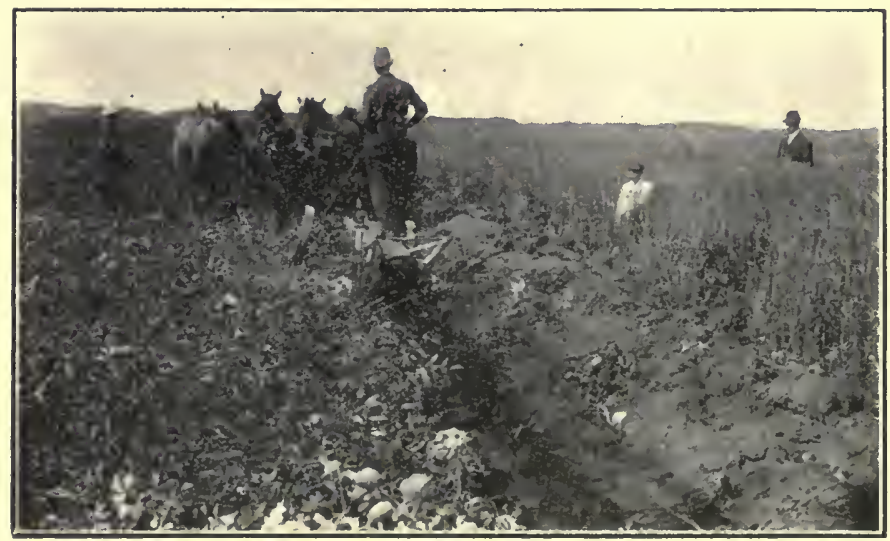

Fig. 51.-Breaking Scrub Land in Manitoba.

generally eonsidered advisable to paek it after smoothing down with the harrow. If this is done in the fall, the last tillage operation in the fall should be harrowing or cultivating. 
106. "Scrub" Land must be Treated Somewhat Differently.-On land that carries a growth of bushes and small wood, backsetting is seldom practicable for the reason that the growth plowed under does not decay in time to permit it to be backset. Under these conditions very deep plowing followed by packing and thorough surface cultivation is the best procedure.

Early breaking on "scrub" land has all the advantages of early breaking on prairie land, but because of the fact that most of our "serub" land is in the more humid parts of the eountry or in areas of low evaporation, it is not essential that the plowing be done as early as in the prairie seetions. $\Lambda$ t the same time it is well to keep in mind that the earlier the work is done the more moisture there will be conserved and the earlier the rubbish is plowed under the quicker it will deeay and leave the soil in good physieal condition.

107. Leave Breaking Uncropped until the Following Season.-In nearly all eases it will be found more profitable to leave the plowed prairie land uneropped until the following year rather than to sow it the year it is broken. If a man is begimning farming operations with little eapital and must have some cash return or grow feed for stoek in the first season it may be good business to sow some crops on new breaking. This, however, should seldom be praetised in the eastern Chinook region. It gives best results in the park belt and eastern portion of the prairie area. In any ease the work should be done early and well. The praetice is risky but occasionally results satisfactorily. It is not one to be recommended in the drier districts because it fails too frequently, and whether it fails or not, leaves the land in poor eondition for the next erop. 
Flax has proven the best eash erop for spring breaking in the prairie area, and oats the best feed erop in all parts. Corn does very well on spring breaking and has the advantage of leaving the soil in good condition for another crop. Potatoes are sometimes planted under the sod with fair results in favorable seasons.

\section{The "Breaking" up of Cultivated Grass Land.-}

In goneral the practices found advisable in breaking prairie sod apply also to the plowing up of eultivated grass land. The drier the district the greater the neeessity of June breaking. In parts of Manitola, northern Saskatehewan and northern Alberta plowing immediately after the hay erop is removed in July is found to give very satisfactory results exeept in abnormally dry years. Packing or planking after breaking is advisable. Backsetting is never necessary if the grass is wester'll rye or timothy or mixtures of either of these with elover. But if brome grass or Kentucky blue grass is grown backsetting will be necessary to control it. The former is muels more persistent than the latter, but even the Kentucky blue grass is diffeult to kill with only one plowing. We have also fomd that the hardy alfalfas camot be satisfactorily killed by once-plowing. A shallow plowing early in the season followed by packing, and then backsetting after the gromud has well settled and before the growth of unkilled plants becomes too strong, is a good proedure with this arop. Where harksetting is not neessary the general practice is to pack the land, double dise it as soon as convenient, and harrow to give it a miform and level sulface for seeding. 


\section{CIAPTER VIII.}

\section{PREPARING PARK BELT LAND FOR ITS FIRST CROP}

The southern part of each of the Prairie Provinces is an open plain, for the most part free from trees. On the northern border of this treeless region the character of the vegetation changes until an intermixture of trees, shrubs and open prairie is found which gives to the landseape an added beauty and suggests the name by which it is eommonly known, the park belt.

109. Location and Extent.-The southern edge of this belt touches the international boundary line near the eastern boundary of Manitoba and passes generally in a northwesterly direction, reaching its most northerly point in the western part of eentral Saskatehewan, from which point it turns gradually southward until it tonches the foot hills of the Rocky Mountains in southern Alberta. No elearly marked boundary between the prairie and park belt exists. In some of the prairie area there are places where "scrub" and even small "bluffs" may be found. Likewise in the park belt there are frequently found large areas of open prairie. To the north of the park belt very little open prairic is found, the vegetation is more dense and the trees are as a rule larger than in the park belt. The width of this intermediate zone or park belt varies from a few to many miles. 
110. General Characteristies.-Within the boundaries of the park belt may be found as many different soil types and almost as great a variety of elimatic "onditions as exists on the prairie to the south of it. In

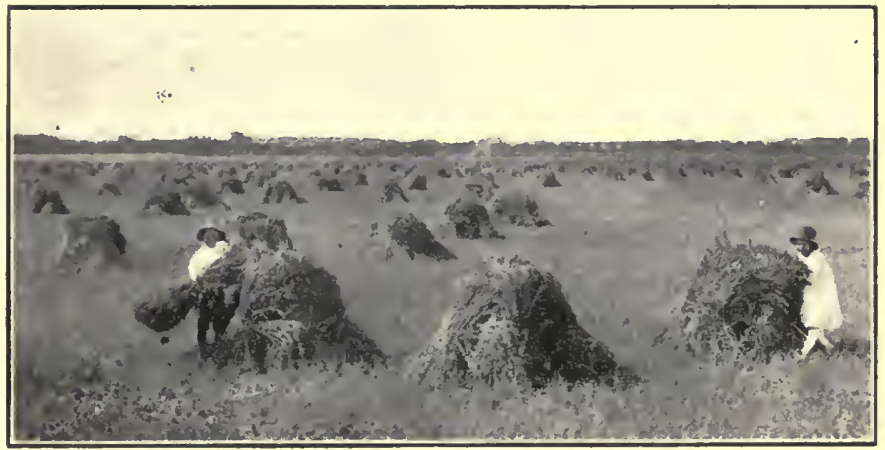

Pig. 52.-Typical Scene in the Park Belt of Manitoba.

some respeets, however, all parts of this region are eomparable; they present the same problems to the settler; the growing season is generally shorter and the evaporation less than in the prairie areas adjoining; hay and pasture erops as a rule do better than in the open plains immediately to the south; the production of eoarse grains, mostly oats, is the general but not exelusive practice, the early ripening varieties of wheat and some barley also being grown; and the practice of mixed farming is the general rule.

111. Climatie Conditions.-The preeipitation is generally thought to be higher than in the open plains, although the meteorologieal records do not make this very evident. The evaporation of moisture from the soil is probably less owing to the lower average temperature 
and lower wind velocity. The frost-free season is shorter than on the prairies and the danger from early fall frosts and summer frost is greater.

112. Character of Vegetation. - In addition to the grasses and leguminous plants which usually oceupy the open spaces many species of shrubs and trees are to

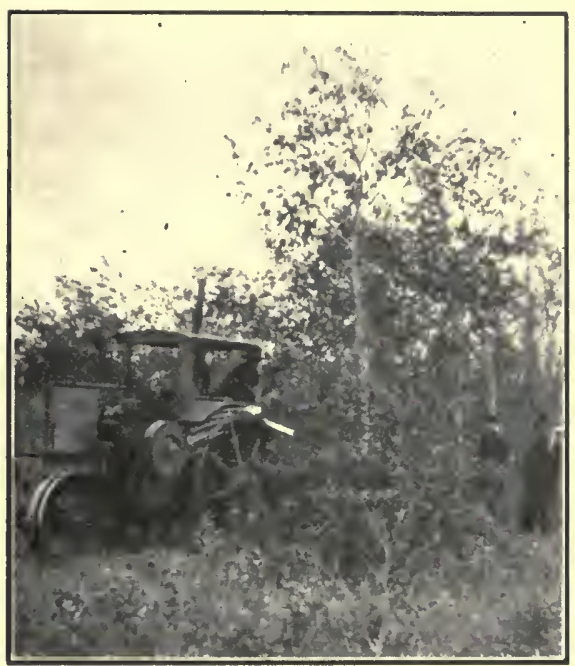

Fig. 53.-Removing Small Trees with Tractor. be found. From the point of view of the settler the latter may all be classed as either brush, or trees of different size. $\mathrm{By}$ brush is generally meant the small s li r u s that may be ent with a seythe, a scrul, hook or a mowing ma ehine, or whieh may be plowed under with a heary plow. The small trees are those that after being eut with an axe or burned off leave a root whieh is not too large to prevent plowing. The larger trees vary from four inches to a foot or more in diameter and unless burning is practised these have either (1) to be chopped down and the roots grubbed ont, (2) to be pulled over by horses or engine power and the roots removed from the soil, or (3) to be ent down by brush- 
cutters or by hand labor and the ground then plowed by using specially built serub plows, after which the roots are removed.

113. Methods of Removing "Scrub".-Where labor is cheap the best and most satisfactory way is to have the serub grubbed out by hand, using grub hoes and axes. In a few districts eheap labor may yet be secured; where contracts have been let to half. breed workmen, the results havi been very satisfactory.

When theap labor eannot be obtained scrub may be pulled with a team of horses. A strong chain or steel c a ble is put around a tree or clump of small

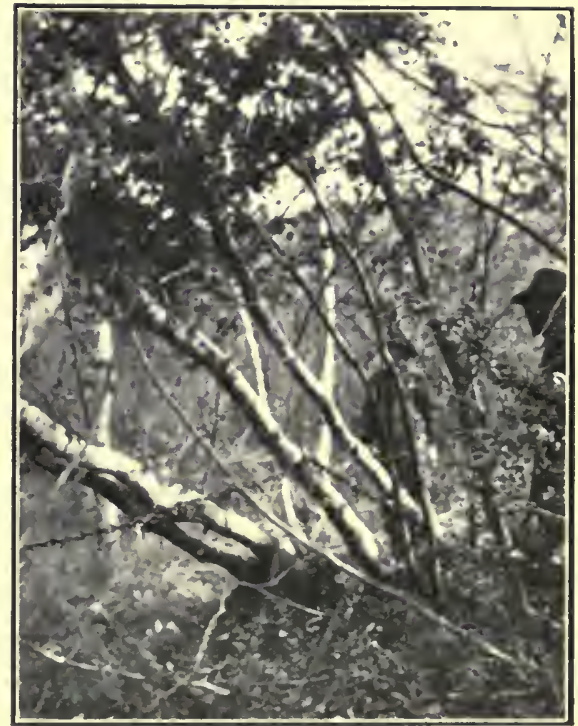

Fig. 54.-Pulling Trees with Tractor. showing method of attaching chain.

trees at a height of six or eight feet; these trees are then drawn out. The roots below the stump are fored out of the ground when the tree is drawn over, and if they are too heary for the horses to pull clear of the soil they are chopped oft below the stump. When this method is employed, a grood teamster is needed if one does not wish his horses spoiled for steady drawing. 
A plan similar to the above but in which tractor power rather than horse power is used is eoming into more general use. This has proven a very satisfactory method, and when labor is high priced, has been found quite economieal. By this method quite large trees with their stumps are pulled ont, the land being then broken easily with a scrub-breaking plow.

Another method is to eut the brush off level with the ground either with the axe or a brush eutter and then to

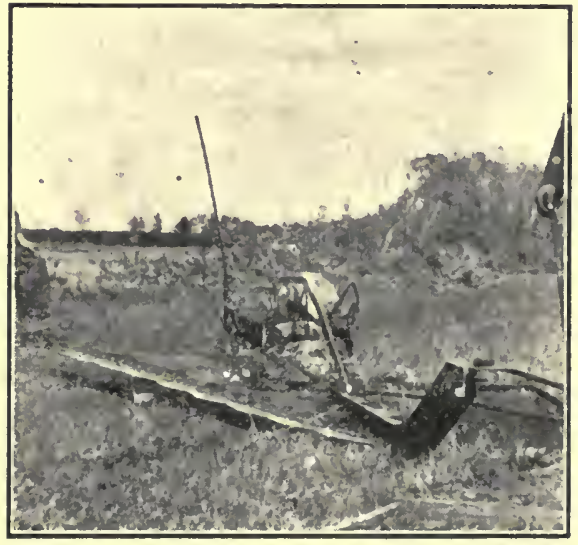

Fig. 55.-Scrub Cutter.

Sometimes used for removing trees in Park Belt land. plow the land with a serub breaking plow which will plow right through the stumps, and turn them over leaving them on top to be picked up later and carted away.

In each of the methods so far referred to, the brush and roots are piled and then burned.

Another method frequently followed is to burn over a piece of land for several springs in suecession in order to clear it of all the trees and underbrush, and then break the land with a brush breaker hauled either by horses or tractor power. This is a good way when one 
is not ready to break the land the first year it is burned over.

114. Plowing Scrub Land.-The eommon practice in breaking serub land is to plow about five inches deep, but if the roots are large deeper breaking is necessary. The best depth to plow depends on the size of the roots in the ground, it being necessary to plow that depth

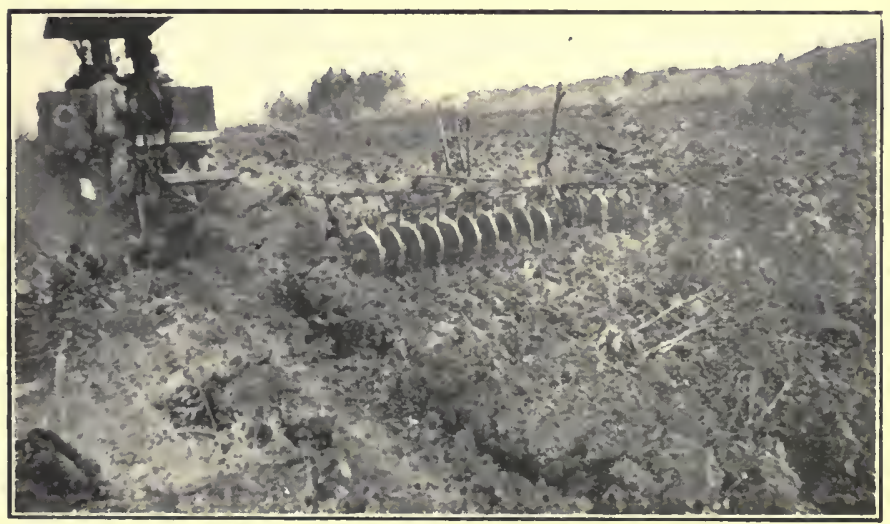

Fig. 56.-Plowing and Disking Burned-ovor Scrub Land.

whieh will enable the implenent to turn a good furrow. Under some conditions a furrow ten inches deep and two feet wide is turned.

The plowing is usually done in June and July. The drier the distriet the earlier the land should be broken and the more moist the distriet the longer it may be delayed. In the more favored parts and in favorable seasons elsewhere the land is sometimes broken early and after being well worked down is sown to oats for feed. Where the soil is rieh and the rainfall suffieient this is a good practice. In fact in some places it is considered 
the best plan, as otherwise the first erop following is heavy and weak in the straw and more subject to lodging or fall frosts. In the drier distriets no crop the first year is the general rule.

Backsetting serub land is not generally practised until one or more crops have been grown. It is seldom necessary and it is usually diffieult or impossible. When all roots and brush are removed either before or after, or at the time of the first plowing, backsetting is possible and is oceasionally practised.

115. Surface Tillage After Plowing.-After scrub land is plowed any loose brush and exposed roots should be removed and the land worked down to a level surface

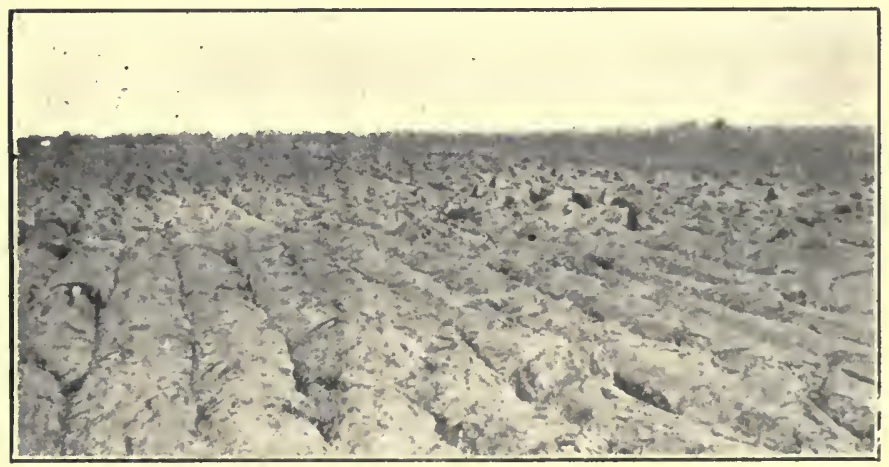

Fig. 57.-How Scrub Land Looks After Plowing.

This area did not contain many stumps of trees over five inches in diameter.

with a packer or heary planker followed by dises and harrows. The sooner this ean be done the easier the vegetation may be killed and the less the land will dry out. Scrub-breaking usually re(uires eonsiderable disking before the surface is level enough to make a satisfactory seed bed. Aside from getting the land levelled down, 
it should be tilled sufficiently to keep down all vegetation and to leave the seed bed in good eondition for spring seeding.

116. Cost of "Scrubbing" and "Breaking".--The cost of scrubbing, breaking and getting scrul land ready for a erop varies widely, depending chiefly upon (1) the percentage of open land, (2) the size, kind and condition of the serub, (3) the eost of labor, (4) the method followed, and (5) the type of soil. Ordinarily it ranges from $\$ 5.00$ per aere to $\$ 20.00$ per acre more than the eost of breaking and preparing prairie land. Heavily timbered land with no open areas costs mueh more than these figures. Very little of sueh land has yet been brought under enltivation.

117. The Choice of the First and Subsequent Crops.When spring breaking is eropped the year it is done the crop used is invariably oats. It is usually put in for "sheaf feed", but in occasional years the crop matures and yields enough to be woll worth threshing.

When not eropped until the following year both wheat and oats are commonly used. Where there is but little danger of fall frost before the crop is ripe, wheat, preferably an early variety, should be chosen. If there is fear of damage from fall frosts oats are to be preferred. Among wheats Marrunis is quite (ommonly used. Some of the earlier and lighter yielding rarieties, such as Prelude and Red Bols, are also grown to some extent. In addition to the varieties of oats rommonly used in the open plains-Banner, Victory and Gold Rain-Abundance is grown to a eonsiderable extent in the park belt. Ligowo, an earlier, lighter-yiclding oat, is also grown to some extent. Daubeney and Mlaska, very early but inferior vielding oats, are also used. Where the season is 
not too short the Gold Rain variety has much to recommend it.

Although too few tests of barley varieties have been made to warrant any conclusive statement, it appears that the six-row varieties are likely to be best for this region. Manchurian and 0 . A. C. No. 21 are the stand-

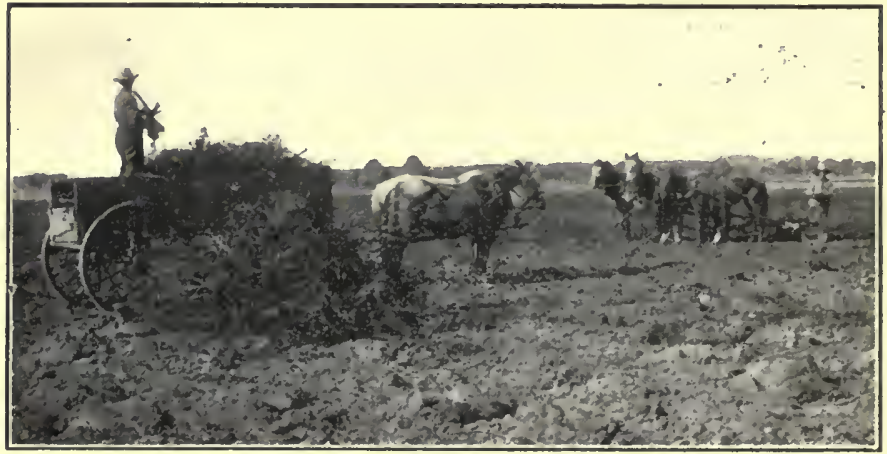

Fig. 58.-Removing Roots and Brush.

On the more heavily wooded Park Belt land the removal of roots and brush after plowing and disking is a necessary operation.

ard sorts, although a true six-row sort known as "California" barley offer's much promise. The best of the very early, but lower-yielding and shorter-strawed barleys, is the Early Six.

Spring and winter rye are also grown on a small aereage of the park belt. Prolific is a promising sort of spring rye, while N. D. No. 959 is probably the best winter variety.

Among peas the early varieties are to be preferred. Arthur has been commonly recommended in the past. Early White is recommended for Saskatchewan conditions and Alberta Blue is spoken of very highly in Alberta. 
The best grasses for the central part of the park belt are Western Rye and Brome. In the western and the eastern ends of this area Timothy is used to a considerable extent. Where pasture is desired and Brome grass is not popular Kentucky Blue grass is frequently used.

Red Clover is coming into use in a small way in the park belt areas where Timothy is recommended, while Sweet Clover is likely to prove more satisfactory in the drier parts.

Roots and potatoes find a very favorable environment in the park belt, particularly, in those parts having more than fifteen inches precipitation.

118. The Best System of Farming. - The best system of farming in the park belt is eoarse grains and stock, or mixed farming. Except for some local areas like the Dauphin district of Manitoba, the park belt distriet is not as well suited to wheat growing as the open prairie, and it is far superior to the latter for the growing of oats, barley and forage crops. It is also better protected from the winds of winter and better watered, thus making it more favorable for stock growing than the open plains.

It seems elear that this region is eventually destined to be among the safest farming distriets of the West. In the early days of settlement the returns are slower in coming than on a prairie farm, but once a park belt farm is improved and a good system of farming established, it immediately becomes a safer business proposition than the average farm of the open plains. 


\section{CHAP'IER IX.}

\section{THE TILLAGE OF STUBBLE LAND}

Land that has borne one or more erops of wheat, oats, barley, rye or flax is commonly spoken of as stubble land. The control of the yield of crops on such fields is one of the most pressing problems in production now facing the grain grower of the open plains. In view of the fact that at least two-thirds of the present eropped acreage of this area is stubble, it would seem that the preparation of this portion of our eultivated land should reeeive very much greater consideration than it has ever beell given before.

The surplus moisture stored in fallowed land is at least a partial insurance against failure of the next season's erop as a result of drought. The same is true, in a lesser degree, of prairie or sod land that has been "broken" and left unsown till the following rear; but on land that has produced one or more crops the soil moisture is largely exhansted, and the next suceeeding erop is almost wholly dependent upon the amount that falls as rain or snow after harvest time. Because of this it is probably true that we shall never, on the average, get as good returns from the stubble erop as from that sown on fallow or "breaking" or after "hoed" crops. Nevertheless, much ean be done to increase the produetive power of such land. 
119. The Causes of Low Yields.-The eauses of low yields on stubble fields are usually few in number. The most common ones are:-

1. The low moisture content of the soil.

2. The presence of grass, shrubs and weeds.

3. A poor seed bed.

4. Insuffieient "available" plant food.

5. The stubble itself.

6: Unavailable soil moisture.

The first is the most general, but any one or all of the others may be contributing eauses of poor erops. A few

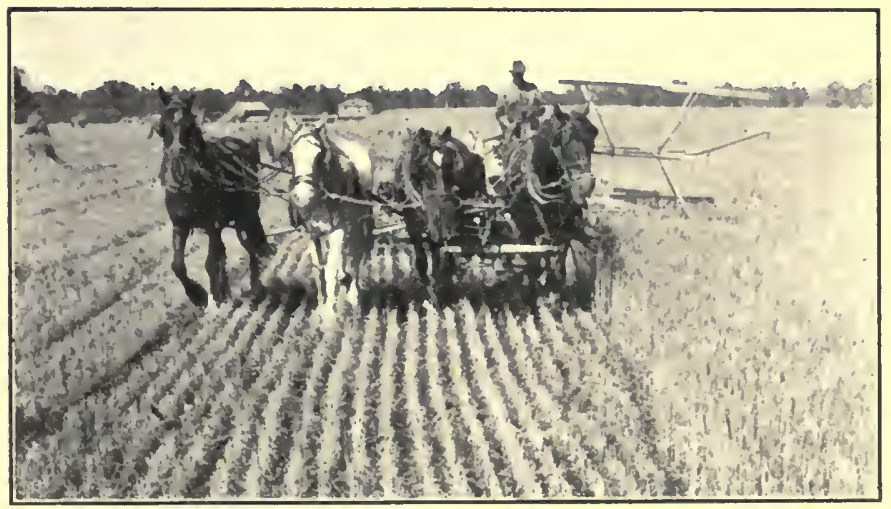

Fig. 59.-Harvesting Wheat near High River, Alberta.

On the left may be observed a fairly typical surface covering of wheat stubble.

of these cannot be controlled absolutely, but all can be materially influeneed by man and some are entirely within his control. Each is affected by tillage, but, umfortunately, the tillage operation which produces a favorable condition in one often prodnees an unfarorable condition with respect to another. Hence no fixed pro- 
cedure ean with profit be followed on all fields. The actual causes of low yield on a given field must first be determined and then the cultural treatment that is likely to control these particular causes must be given, if the largest net advantage to the farmer is to be derived.

120. The Control of Soil Moisture.-The low moistur: eontent of the soil is the principal cause of low yields on stubble land. "A dry season", "too little rain", "hot winds" are generally given as causes of partial failure. So far as this portion of the general problem of managing stubble fields is concerned only two things can be done-(1) endeavor to prevent the moisture already in the soil from escaping, and (2) try to get more in.

The moistutre in stubble land escapes in only two ways-by evaporating directly into the air and by being transpired by weeds or other volunteer plants growing on the land. The loss by evaporation from most stubble fields in dry climates is very little, probably not suffieient to warrant any but the cheapest form of tillage or muleh making, if for this purpose only. The loss of moisture through the growth of weeds is very great and this can and should be controlled by killing the weeds when they are small.

Getting additional moisture into stubble fields in fall and spring is a more difficult problem in this climate than keeping in what may be already there. Our autumn, winter and spring seasons are dry. In the seven months from September to March, inelusive, only about one-third of the year's precipitation falls, and a large portion of this is in the form of snow and, therefore, not easily controlled. To prevent the "run off" in spring, plowing is preferable to surface cultivation or no enltivation, and fall plowing is better than spring 
plowing. But "fall plowing dries out" and if left unplowed "the stubble holds snow." If in plowing in the fall to store moisture which seldom falls we prevent the aceumulation of snow in the stubble and also lose some moisture that is already in the soil, what is the net result?

121. The Control of Weeds, Grasses and Shrubs.-The surface of stubble fields is often infested in the fall with weed seeds of various kinds. They seldom germinate until the following spring when they make their appearance in the growing erop, using up tons of moisture, lessening the yield and inereasing the cost of cutting, stooking, threshing and marketing the crop. As a rule sueh plants mature and drop their seed either before or at harvest time, making the problem of eoping with them still more difficult.

In the control of annual weeds in stubble fields that are to be eropped again the object should be to get as many as possible of the weed seeds germinated in the fall, as most of them will die when subjected to the low temperatures of winter. Some form of eultivation will best aecomplish this result, while thorough late fall eultivation or fall plowing will completely control the biennial weeds which make the early part of their growth in the late summer or fall. If, because of dry weather, fall eultivation does not prove effective in starting the weed seeds to grow, it will in any case induce early spring germination and enable one to kill the young plants by subsequent eultivation. This is of great importance on land that is to be fallowed. I part from destroying the weeds themselves, anything that can be done to insure a uniform and vigorous stand of grain in 
the spring will be of great value in erowding out weeds in the stubble crop.

The perennial plants, among which the native quack, sweet grass and prairie rose are the most common, are serious pests in many stubble fields. They spread not only
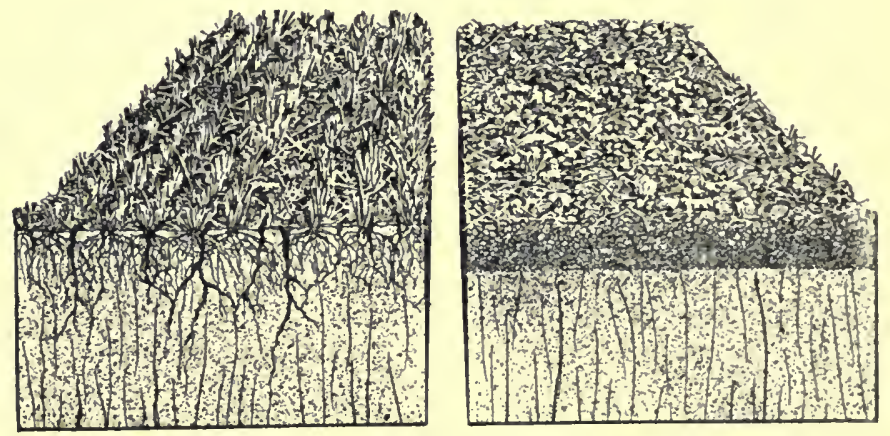

Fig. 60.-Effect of Disking Stubble Land.

Diagran showing on the left uncultivated stubble, and on the right double disked stubble. Note the absence of cracks in the subsoil of the cultivated land.

by seeds but by underground ereeping stems. These weeds cannot be eontrolled by burning or disking or other surfaee eultivation. Plowing, preferably in the dry season, when the roots can be exposed to the hot sun and drying wind, is the only remedy for those legaeies of poor breaking. Other plants of a similar nature are brome grass, Canada thistle and sow thistle.

122. Securing a Good Seed Bed.- $\Lambda$ good seed bed is one that provides the eonditions neeessary for germinationheat, air and moisture-in optimum amount, at the right depth, at the time the seed is sown. Too often the surfaee of our stubble fields is too hard to get the seed into, or too dry to eause germination, or covered with disked stubble through which the drill camnot satisfaetorily 
foree the seed, or the surface soil is in such condition that it does not eover the seed satisfactorily after seeding. The surface soil can be made more mellow by surface eultivation or by plowing; the moisture content can be more or less controlled by the same nucans; the stubble, if too long, may be either burned or plowed under or left uneultivated and the condition of the surface or seed bed can be improved by suitable tillage if neeessary.

123. Importance of "Available" Plant Food.-All of the plant food in a soil eamnot be drawn upon by the growing erop. Since plants "drink" their food it is elear that only that portion of the fertilizing constituents that becomes soluble or available ean be used by them.

The ageneies eausing the breaking down of plant food constituents in soil are more or less dormant during the dry autumn and long winter with the result that the amount of available plant food in stubble fields is relatively small. By far the most important of these ageneies is moisture in the soil. In stubble fields the amount of moisture is very low at best and the supply cannot be materially inereased; but any form of tillage that results in getting more moisture into the land or in preventing weeds or evaporation drawing upon what is already there, will tend to increase the total amount of "available" plant food for the use of the stubble erop.

124. The Stubble-A Nuisance, Yet Important.-The stubble of cereal erops is made up of elements derived hy the plant from soil and air. If the stubble is burned the most valuable fertilizing element seeured from the soil, viz., nitrogen, passes off into the air. The burning of stubble also dissipates "organic matter," the constituent that helps to keep soils from blowing, the one 
that increases the water-holding capacity of the soil and at the same time makes it easier to work. The amount of this constituent in decayed form in a soil is the greatest single index to its "fertility".

But the stubble lessens the efficiency of tillage and seeding operations, and long stubble if plowed under may seriously interfere with the upward movement of soil moisture from the subsoil and with the downward penetration of the roots, thus lessening the yicld. Except on drifting soils or on heavy, tight clay, stubble is
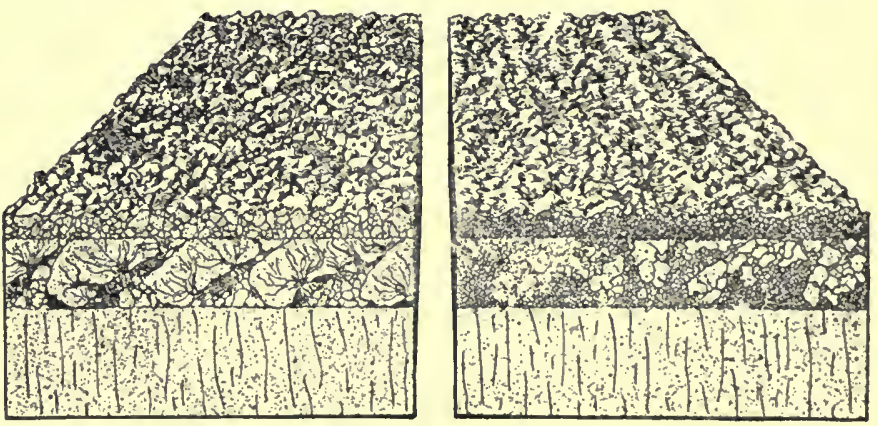

Fig. 61.-Effect of Disking Before Plowing.

Diagram showing on the left, land plowed and then harrowed; on the right, land disked, then plowed and then harrowed. Note the air spaces in the former which result in the drying out of the furrow slice, unless the land is firmly packed.

a nuisance until it decays. It decays rapidly in humid but very, slowly in dry elimates. In the West we need to maintain the organic matter content of our soil, but we hesitate to fill it with too much undecayed stubble, except in the fallow year.

125. Subsoil Moisture Must be kept Available to Plant Roots.-Moisture and "plant food" are both necessary for erop growth. The former is often found in relatively 
large quantities in the subsoil, from whieh acea it may rise to the plant roots by "eapillarity". But frequently in our tillage operations we ereate a condition where the subsoil moisture does not rise fast enough to meet the needs of the erop above, in which ease lower yields result. Such a eondition is produced when the furrow sliee of plowed land is not pressed firmly against the subsoil. Moisture will not rise satisfaetorily through a layer of lumpy or loose soil, or worse still, through an air spaee. The chief reason why more fall and spring plowing is not practised in the dry parts of Western Canada is beeause plowed land has too often been left in a loose condition with stubble and air spaces under the furrow slice, thus largely eutting off the supply of subsoil moisture, with the inevitable result of decreased yields.

126. Some Common Methods of Preparing Stubble Land for a Crop.-Among the methods followed in the different parts of the West for preparing stubble land for a erop are the following:-

1. Seeding on the untilled stubble without previous or subsequent tillage.

2. Seeding as above followed by "floating" or "planking".

3. Disking or cultivating in fall followed by harrowing.

4. Disking or cultivatting in spring followed by harrowing.

5. Burning the stubble in spring and seeding either with or withont disking or eultivating.

- 6. Fall plowing left rough "to hold snow", then harrowed down in spring before seeding. 
7. Fall plowing, harrowing, packing and harrowing in fall.

8. Spring plowing and harrowing.

9. Spring plowing, harrowing and packing.

10. Spring plowing, packing and planking.

The usual treatment after seeding is to pack or harrow or both.

127. Results of Some Tillage Experiments at the University of Saskatchewan.-On the investigation field at

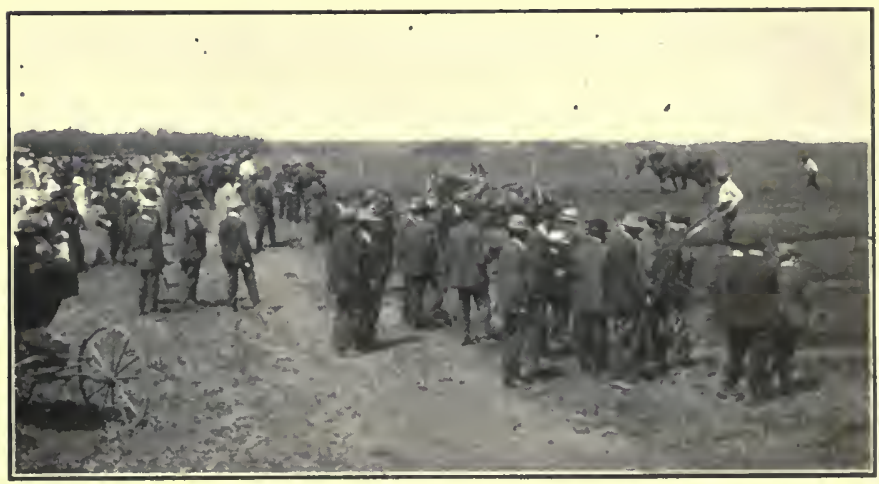

Fig. 62.-Typical Scene at a Plowing Match.

the University of Saskatchewan wheat stubble was tilled in from sixteen to fifty different ways during each of five years and the average yields ranged from $11 \frac{1}{2}$ to $23 \mathrm{r} / 2$ bushels. In some seasons the range between the lowest and highest yield was 30 bushels per acre.

As a result of carefully observing the climate and soil eonditions and of keeping an aecurate record of the behavior and yield of the erops in seasons of different character during a period of nine years, we have learned that many unfavorable conditions in stubble fields ean 
be diagnosed and both the yield and net profit inereased by suitable tillage. No hard and fast rules can be laid down for other soil and other elimatie conditions but a few general prineiples that are of wide application may be drawn from the work. In the diseussion that follows some of these are pointed out.

128. The Necessity for Plowing Grassy Stubble.-The average yield of wheat for five years on untilled grassy stubble was 8 bus. 9 lbs. less than on untilled stubble that was free from grass. There are times when it may not be best to plow clean stubble fields; but there is never a time or condition that makes it advisable to leave grassy stubble unplowed.

In 1914 grassy stubble surface cultivated in the fall, produeed 3 bus. 45 lbs. less wheat and 13 bus. 5 lbs. less oats per acre than fall plowed land that was surface cultivated; and spring plowing produced rather more satisfaetory results than fall plowing in that year. On another piece of untilled grassy stubble the average yield of wheat in 1914 was 5 bushels per aere. Adjoining land in the same grassy eondition was plowed shallow, double disked, paeked and harrowed in the fall of 1913 and as a result yielded 13 bus. 30 lbs. in 1914.

It was observed that in all cases where grassy stubble was plowed the yield was inereased and the grass was either totally killed or very much lessened. When the same land was left unplowed, in many instances it beeame over'rum with native quack or, in low placess, with sweet grass, and the cost of redeeming it was thus materially inereased.

Cereal erops eannot eompete suceesssfully for moisture and plant food with established pereminial plants. Neither burning nor surface cultivation will kill the 
latter, and when they are present in any quantity in stubble fields plowing for the sueeeeding erop either in fall or spring becomes a necessity.

129. The Desirability of "Working Down" Plowed Land as soon as Possible after Plowing.-The farmer in humid regions wants air in his soil in the fall. In order to prevent the furrow settling down and beeoming hard and more or less baked, he leaves the fall-plowed land loose and untilled. Dry farm soils, however, usually do not suffer for want of air. The dry land farmer is more eoncerned about saving moisture than about getting more

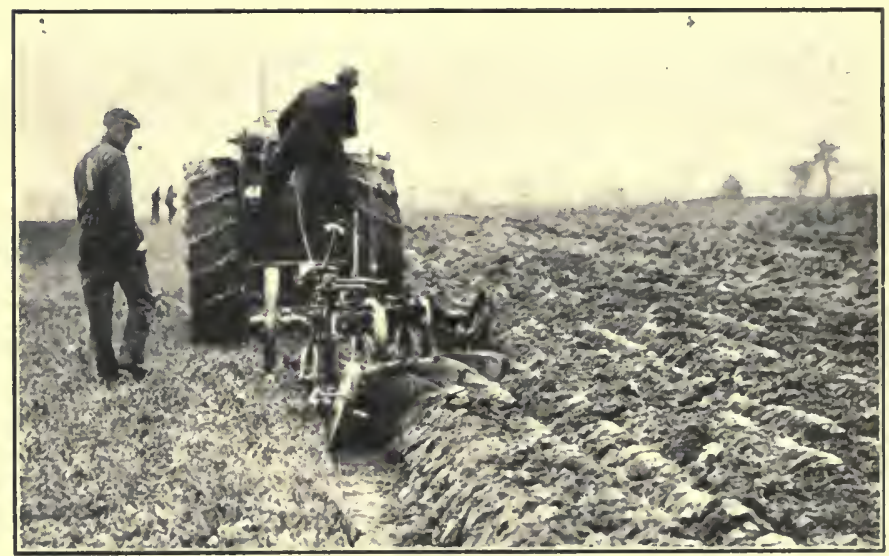

Fig. 63.-Tractor Plowing on Stubble Land.

air into the land. The dry parts of Western Canada do not enjoy a humid elimate, and unharrowed or unpaeked fall or spring plowing instead of settling down and baking usually dries out.

On a new soil that did not blow the inerease in yield from one operation of the heavy harrows or two of the 
light lever harrows the same day the plowing was done, was 1 bus. $57 \mathrm{lbs}$. in the average of a large number of tests over a period of several years. It is evident that on soils that blow as well as on those that run together and bake readily in the spring similar results would seldom obtain. On normal soils, however, and partieularly on spring plowing either harrowing or packing as soon as possible after plowing is a very important and necessary operation.

Various methods are followed to try to prevent the drying out of the plowed furrow. The simplest is harrowing as soon as the plowing is done; another is to harrow at onee, then pack and then harrow; a third, to pack with a paeker attachment to the plow, then follow with a plank drag or serubber and then the harrow. On fall plowing that has been well worked down ridging with a cultivator is sometimes practised.

The practical man must, however, keep in mind that while normally the more intelligent tillage that is applied the greater the yield is likely to be, yet a paying inerease in yield from the excessive tillage of stubble land in dry areas is not by any means assured; while the extra cost cannot by any chance be evaded. The question is not one of yield alone, but one of net return. 'There yet remains much work to be done before the most effieient combination of tillage practices and sequence of operations can be definitely stated for all soil types in all climatic zones of the West.

130. The Furrow Slice Should be Placed Firmly Against the Furrow Bottom.-In humid elimates the practice of turning the furrow over flat is not eonsidered advisable for the reason that the soil is likely to mun together and beeome too hard. In semi-arid regions, except on a few 
types of heavy elay, the danger is not in its running together too much but in its not rumning together enough. In addition to turning the furrow as flat as possible it is important that it be plaeed firmly in eontact with the subsurface soil. This ean be done by using a land packer or by thorough surface eultivation, or, if the plowing is done early enough, the rains accomplish the same end and at no cost.

A summary of all our work with the "surface" land packer on fall and spring plowing shows that packing deep plowing inereased the yield of wheat 2 bus. and 6 lbs. per acre, and packing shallow plowing, 40 lbs. per aere, while packing unplowed stubble land decreased the yield three years out of four. It was observed that where packing was done the erop was invariably more uniform and earlier. It is generally eonsidered advisable, except on soils inelined to drift, to follow the packer with the harrow, particularly if the packing is done after seeding.

131. Burning Stubble is Permanently Wasteful of Soil Fertility, but Often Immediately Profitable.-The five-year average yield of all stubble land that was surface eultivated in any way was 22 bus. 25 lbs. of wheat, while the average for the same length of time on land that was burned and then surface cultivated was 22 bus. 49 lbs. per acre.

A very much greater inerease from burning has been reported from the Qu'Appelle Valley and the Regina Plains, where the soil is heavier, and where the stubble grows longer and holds more snow. It would seem that on heavy, rich soils, where the straw grows tall, burning in the spring after the long stubble has been left to gather snow, is a practiee that, for immediate profits on new land, is condueive to good net returns. On the other 


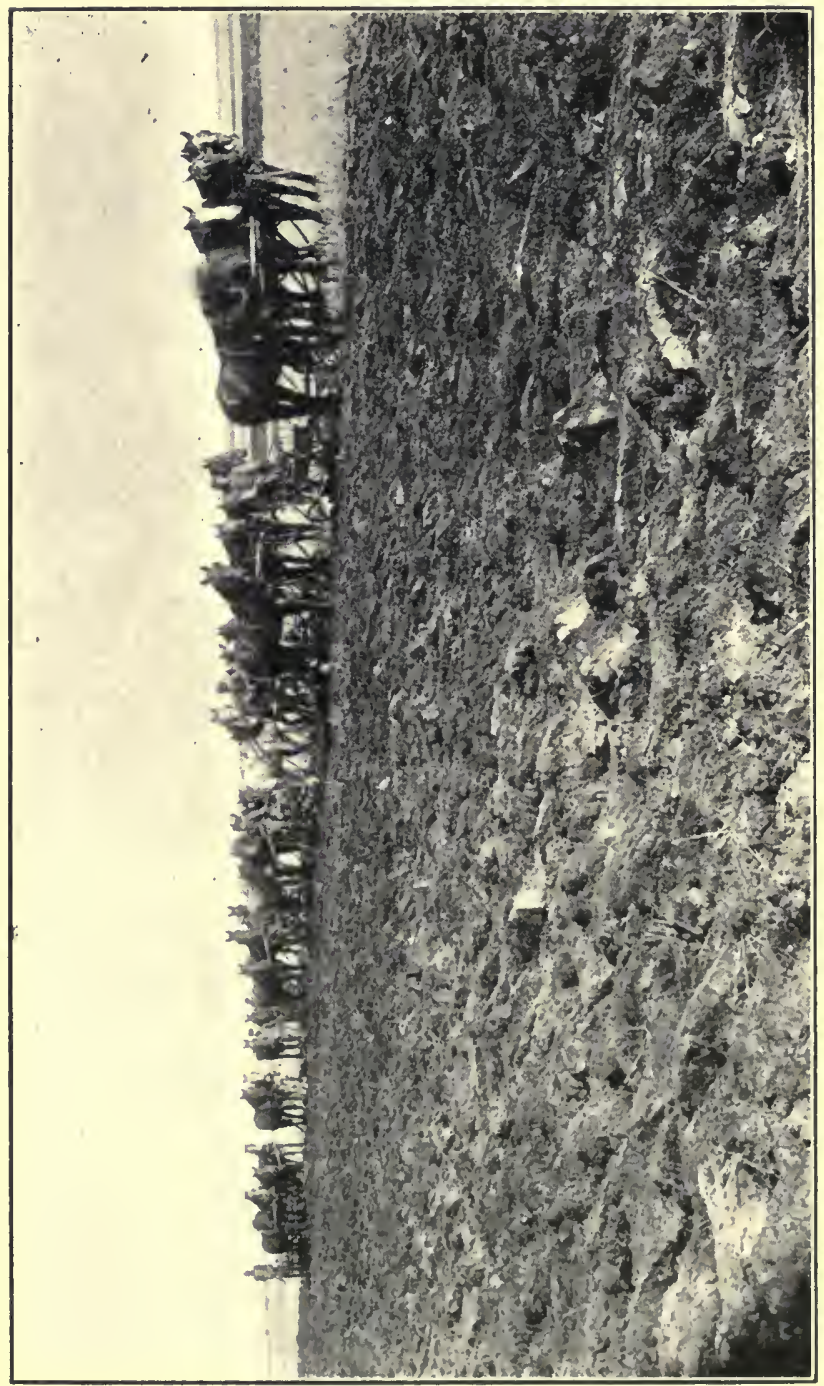


hand, this method does not give opportunity for controlling the spread of annual and biennial weeds. In regions where spring burning has been followed for any length of time these are very abundant.

In some older distriets where weeds are prevalent, and where the soil blows so badly that the drift covers stubble flelds and renders spring burning impracticable, fall burning and surface cultivation is sometimes practised. A good burn eannot always be obtained in the fall, and in addition this practice is generally more dangerous to property. Fall burning offers better opportunity to kill weeds, but less to hold snow and aceumulate moisture.

The chief faults of stubble burning-and they are very serious faults-are the great waste of organie matter and nitrogen and the laek of opportunity spring burning offers for the control of weeds. The figures quoted above and the apparently favorable inerease in the results from burning stubble are to a considerabale degree misleading. There are no long time records of the yield on land burned off from year to year as compared witl similar land that has not been burned off. All available reeords of such tests in Western Canada have the fundamental fault that they are not taken from eontinuously burned versus continually unburned fields, but rather from plots that have been similarly treated until the spring the erop is planted. This is obviously not a fair eomparison of the residual effeets of stubble versus the ash of stubble.

The experience of the Northern States in burning stubble and of the corn belt States in burning corn stalks is to the effect that while there is apparently a slight immediate advantage in burning, this is more apparent than real, and the subsequent effects are such as to con- 
demn the practice wherever formd. The best evidence indicates that the sooner we can find a substitute for burning stubble the better it will be for the land, as well as for the people who oecupy the land after us.

\section{Surface Cultivation Sometimes Preferable to Plow-} ing.-In the year 1912 on rich friable land that was free from weeds and grass, as large returns were secured in a second erop after a good fallow from sowing wheat on untilled ground, as was seenred from the most intensively eultivated field. The practice of plowing for a second crop is not so necessary in a dry climate on soils in good physical condition as those of us who come from a more humid area are likely to suppose. In the absence of grass and in the presence of short stubble, soils of good physical condition often produce as large net returns with eereal crops when thoroughly double disked early in the fall or in the spring immediately before seeding as when fall-plowed. This is particularly true in the drier parts of the prairies on land that is well fallowed every third year. Disking fields that have a long stubble is objectionable since it places the stubbles in a horizontal rather than an upright position and thereby lessens the efficiency of the seeder. I'nder surch ronditions the stubble is often, in practice, either burned off or the field left uncultivated. "Stubhling in" either" on cultivated or uncultivated stubble is not advisable, exeept on clean land in a grood state of tilth. On old land plowing is generally advisable-fall plowing being peeferable in the humid regions and in wet antumms, and spring plowing in the dry recgions and following dry antmonis.

The average yicld of wheat on surfare ("nitivated stul)ble at Saskatoon on elean land has been 2.2 bus, 2.5 lis. 
and on plowed stubble, 23 bus. $16 \mathrm{lbs}$. On older and more weedy land the inerease from plowing is very much greater although on new clean land the second crop after fallowing is sometimes more profitable if left unplowed.

133. Early Fall Preferable to Late Fall Cultivation. -In the 1911 wheat crop early fall plowing increased the yield 1 bus. 36 lbs. over fall plowing done three weeks later. In 1913 the inerease due to the earlier work was 1 bus. $12 \mathrm{r} / 2$ lbs., while in 1914 it was 3 bus. 4 lbs. per aere. The inerease from early double disking was 1 bus. 10 lbs. per aere. It is often impossible to plow land early after harvest on aeeount of its hard, dry eondition. It is sometimes impossible to get time to dise it, but if it is planned to earry out either of these practices the sooner it ean be done the better the results are likely to be.

134. Avoid Working Tight Clay Soils when too Wet.In the spring of 1913 some sticky clay portions of our investigation field were plowed when the soil was too wet, with the result that they "baked", and the yield was cut down to less than half that seeured on other lighter soils worked at the same time. Light soils are not likely to be hurt by working them too soon after heavy rains, but medium soils may be, and some heavy soils are invariably injured by this praetiee. The chief objection to plowing the heavy soil in the Red River Valley in the spring is that it is likely to bake and as a result give a very unsatisfactory germination and early growth.

135. Harrow the Growing Crop only when there is Cause for so Doing.-Weeds growing in a erop deerease the yield. Moisture that evaporates produees no wheat. After a crop is up many weeds may be killed, and evaporation from a too firm soil may be lessened by 
harrowing. If weeds are present and the surface soil quite firm it is generally advisable to harrow. If weeds are not present and the soil contains suffieient moisture to produce a good crop, harrowing is not advisable except as a preventive measure against weeds in potatoes or corn. Neither is harrowing advisable where there is any tendeney of the soil to drift.

Harrowing a growing erop is a practice in which judgment must be used. A thin stand means later maturity. Harrowing invariably pulls out some of the plants, thus leaving a thinner stand. This is particularly true on light, loose soils, or on fields earrying eonsiderable rubbish in the form of stubble. On fields in this condition, harrowing, if done at all, must be practised with eare. A light lever harrow with the teeth tilted slightly backwards is often to be preferred for this work.

136. General Observations on Plowing Stubble Land.The best time to plow, whether in fall or spring, and the best depth to plow, whether deep or shallow, varies considerably under different eonditions. It has been pointed out that each of these four praetices has in different seasons produced the largest yields. The plowing that proved best generally was that done at the time the soil was in the best condition.

Early shallow fall plowing, well worked down, has given at Saskatoon slightly larger average yields than spring plowing of any depth; but spring plowing has given us larger average yields than late fall plowing. The data at present available do not favor the teaching often advaneed that deep fall plowing is always best for the seeond or third erop after fallow in elimates surh as ours where dry autumn, winter and spring seasons are the rule. At the same time, when plowing is done 
in the fall it does not have to be done in the spring. It is well to keep in mind that until spring plowing is finished it is not ready for a crop and may not be ready until it is too late for good results. Fall plowing is quite generally praetised in the more humid parts of the West, but in the drier areas it is not considered a desirable practice mnless the soil is in good condition at the time of plowing.

Deep fall plowing gave us good returns when the soil was in eondition, and when the antumn was moist and the winter snowfall heavy. Very favorable yields were

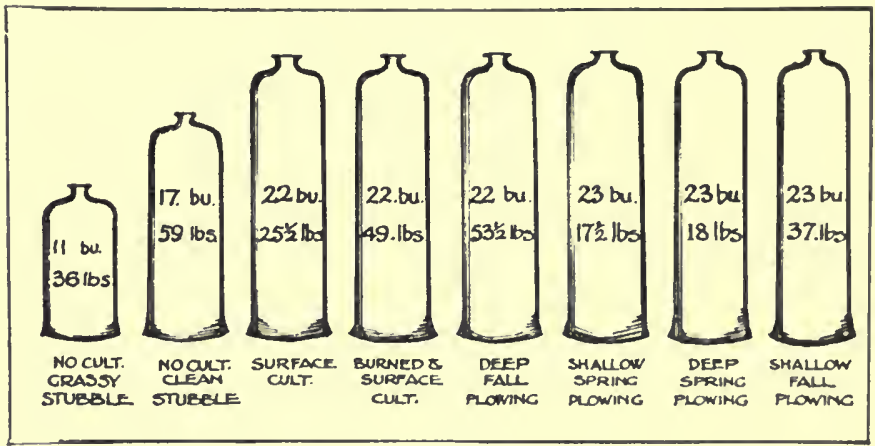

Fig. 65.-Summary of Tests.

Different methods of cultivating stubble land at Saskatoon.

also obtained from deep fall plowing on land that was infested with quack grass and native shrubs, and also where long stubble could not be bumed, providing in each ease the land was well worked down afterwards; but it gave us poor results when the fall and winter following were dry, as most of our fall and winter seasons are, and very poor results when a heavy stubble was plowed moler and the land not worked down after plowing. 
Deep fall plowing as a general rule, is likely to produce less favorable yields in our climate than in a humid one, and less in the dry parts of the West than in either the eastern or northern parts. It would also seem from the point of view of weed control that deep fall plowing before weed seeds have germinated should be discouraged.

Spring plowing permits of the stubble holding snow when there is any to hold and gives less opportmuity for the plowed soil to dry out. In other respects what has been said of fall plowing applies in a general way to spring plowing. It lias been observed, however, that spring plowing for oats gives more favorable results than the same cultivation does with wheat, and invariably it produces more of any cereal than fall plowed land that is left mitled and allowed to dry out. Favorable results from spring plowing for barley have been reported by many different farmers.

It might here be emphasized again that in the drier parts both fall and spring plowing should be firmed and well harrowed down, ot herwise very disappointing yields may often result.

137. The Importance of "Net" Returns.-From what has been said it is apparent that fair yields can be produeed on stubble fields. Our aim, however", must be to produce "net" profits rather than "gross" returns. A large viold is not always the most profitable. On the other hand a poor yield, even though no cultivation has been given, may not pay the interest and maintenanoes charges on the necessary investment in land, huildings, machinery, fencess and stoek.

As long as land is cheap and labor and erpuipment are high in price intensive methods on stublole land are not 
likely to prove as profitable as carefully thought out and intelligently practised extensive ones. Nevertheless, if overhead charges against the investment are to be met the conditions that cause poor crops must be controlled. At the present time in Western Canada intelligent, time$l y$ and sufficient tillage is the greatest means at our disposal for controlling, not only the factors that limit the yield, but the net revenue as well. 


\section{CHAPTER X.}

\section{THE SUMMER FALLOW}

Summerfallow is the name given to that portion of the farm which is left uneropped for a season and the soil managed in such a way that a surplus supply of moisture may be stored in it. Whatever the future of this praetiee may be, summerfallowing is at the present time at least the most fundamental practice of dry farming in the northern great plains area. Nor are its advantages limited to the storage and conservation of soil moisture. The fallow may be used to kill weeds and eause the deeay of stubble and manure when plowed under; it results in the development of available plant food; and on the pioneer grain farm it is at the present time practically an eeonomie neeessity since without the fallow it would be impossible to satisfaetorily prepare all the land for a crop in our short autumn and spring seasons.

The summerfallow is at present an established praetice in all the drier parts of the Prairie Provinees. The objections to it are many and they will no doult force a readjustment of our present system but until some modification of it is found to be profitable every grain grower in that portion of the open plains having less than sixteen inches of precipitation should plan to fallow a half, a third or a fourth of his land every year. 
138. The Function of the Fallow.-The chief and perhaps most legitimate function of the fallow is the storage and conservation in the soil of a portion of one year's moisture as a partial insurance against failure of the mext year's crop as a result of deomght. In some places such as the Red River Valley of Manitoba the fallow is

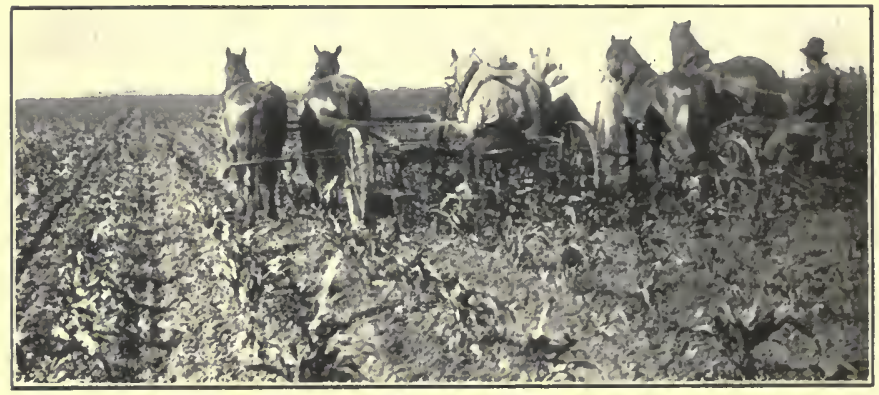

Fig. 66.-Cultivating Corn, Gladstone, Man.

The corn crop is replacing a part of the fallow on some farms.

made to serve tle purpose of weed destruction. In otlers it is used largely because it enables the farmer to make a more economical distribution of the season's aretivities. Whatever its pmrpose in the mind of the man planninge it, the results of fallowing, when properly arried ont, are that (1) the field contains more moisture than otherwise, (2) many weods have beon killed, (3) a large amomit of available plant food has beral accumulated, (4) the decay of rubbish and stubble is arcomplished, and (5) the land is ready for seeding whenever spring opens 11 ).

139. The Practices of Fallowing.-The two chice practicese of fallowing an'e (1) plowing in .June or arely .July (later in the most limmid parts) so as to make the soil receptive for the heary rains of the raing 
season, (it plows easiest, time and power are available and the land is in the best "condition" at this time), and (2) surface cultivating the land to prevent the loss of moisture through weed and other volunteer growth. Other additional practices sometimes followed consist of disking or skim plowing either in the fall or early in the spring before the usual plowing, and of parking the land some time after the plowing has been done. An occasional farmer now fallows without plowing, using only the dise, eultivator and harrows.

From the point of view of moisture conservation, the exsential things about a fallow are (1) to plow reasonably early in the rainy season, (2) to kill weeds as soon as practicable after germination, (3) to surface "ultivate enough to prevent the soil cracking.

Where weed eomtrol is more important than moisture conservation early fall cultivation such as disking. cultivating or skim plowing is desirable to start woed secds growing. Suring cultiration after the first (rop) of weeds starts in the spring is explually important, and plowing shortly after the second crop is up is advisable. The subsecpuent aultivation should be such as will ancomrage weed seeds to grow and the young plants to be killed as soon as possible after germination.

As to whether a particular practice of fallowing will pay depends wholly upon the ciremustances under which it is to be used. No code of rules for fallowing are applieable to all soils in all rlimates. The meerls of the speeifie field must first be known, and theen sule le remedies applied as will best suit the eemelitions that exist.

Disking in fall before fallewing will start some seeds to germinate if the soil is moist. and make the next plowing easiere, but it rests money. 
Plowing the fallow early results in the storage of more moisture and eneourages weed growth but neeessitates added surface eultivation to kill weeds and thus adds to the eost.

Plowing deep takes more time and money than plowing shallow. It kills grass better than shallow plowing and has some other minor advantages, but it does not always give better returns than plowing a medium depth. On deep soils deep plowing in the fallow year is eommonly praetised but on shallow soils that have a light subsoil it is objectionable in the dry parts beeause it encourages soil drifting.

Subsoiling is seldom praetised. In several tests on normal soils it has not paid its way. It is possible that on some "hard-pan" subsoils it might be worth while, but this has not yet been demonstrated.

Plowing twice is advisable only where grass is prevalent or where weeds have gotten ahead of the surface tillage maehines. Skim plowing in the fall followed by the regular plowing in late June and by subsequent cultivation is reeommended for the Red River Valley where the control of sow thistle and wild oats is important and for all other areas where quack grass or sweet grass are prevalent in the land to be fallowed. Harrowing immediately behind the plow lessens the loss of moisture by evaporation from the furrow slice, and results in the formation of a better seed bed but it may make the soil too fine and dry and thus eneourage drifting.

Packing the fallow is often a desirable practice but it may not be essential exeept on land (1) that is plowed late, (2) that plows up in rough eondition, (3) that grows a late erop, or (4) where firming the soil over the seed is desirable. 
Under the last mentioned eondition packing is desirable on soils that are (1) too loose to insure rapid germination, (2) too loose to prevent excessive drying around the plant roots in a season of drought, and (3) not firm enough to aid in the rise of moisture from the subsoil. Packing is to be preferred on late plowed fal-

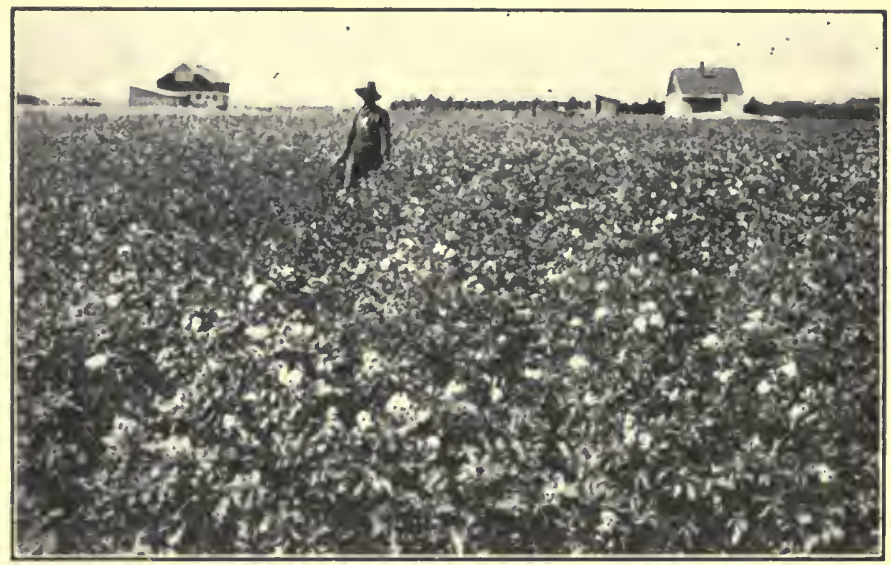

Fig. 67.-Potatoes Under Irrigation North of Brooks, Alberta.

Inter-tilled crops mako fallowing unnecessary on irrigated land.

lows and in dry years. It is most objectionable when praetised on soils that bake. A fallow that is plowed early may beeome sufficiently firm as a result of neeessary surface tillage to make packing unnecessary.

The surface eultivation of the fallow may be by harrows, dises or cultivators. The more soddy the land is the more the dises will be needed; the more grass there is and the greater the development of anmual weeds, partieularly on soils that drift, the more desirable the eultivator is, while on land that seldom or never blows the harrows will prove the more effieient imple- 
ment if used in time. Generally harrowing and either disking or cultivating should alternate each other. As the tendency of the soil to drift increases, harrowing should be practised less frequently, and the cultivator should gradually replace the dise.

As to the condition in which the fallow should be left in the fall the type of soil is the determining factor. A fallow left loose and more or less rongh on top, or ridged as after a cultivator will not run together so much and is to be preferred on very heavy clay soils that bake. Those soils that slake down in good condition in the spring may be left in small ridges. These will hold some snow, will facilitate mulch making with the harrows in the spring and, if harrowed at the right time, will result in a better seed bed and no more blowing than the level surface. The chief objection to the smooth surface is that it frequently holds very little if any snow and there is therefore a very small accumulation of moisture from this source.

140. Objections to Fallowing.-But someone sạts, "I summerfallowed and my crop did not ripen-it got touched with the frost because it was late in maturing", another, "I don't believe in letting one-thirel of my land worth $\$ 40$ or $\$ 60$ an acre lie idle-it isn't good business." Another one says, "The fallow is wasteful of fertilitynitrogen and organic matter-and shonld be discontimued", another "Will not hay erops or hoed cops accomplish all these things claimed for the fallow?", and another, "I did all these things people advise and in the spring after the seed was sown and just as the cop was coming up, the wind rose and the surface soil, because it was so fine, 'drifted' away and the resulting (rop was 'patchy", uneven and minatisfactory", and another, "I 
can't get the weed seeds germinated before the early part of June in diy seasons and object to plowing them under because they will live and grow when plowed up again", and yet another, "I summerfallowed and my (erop was so heavy and rank that it 'lodged', was poor in (plat-

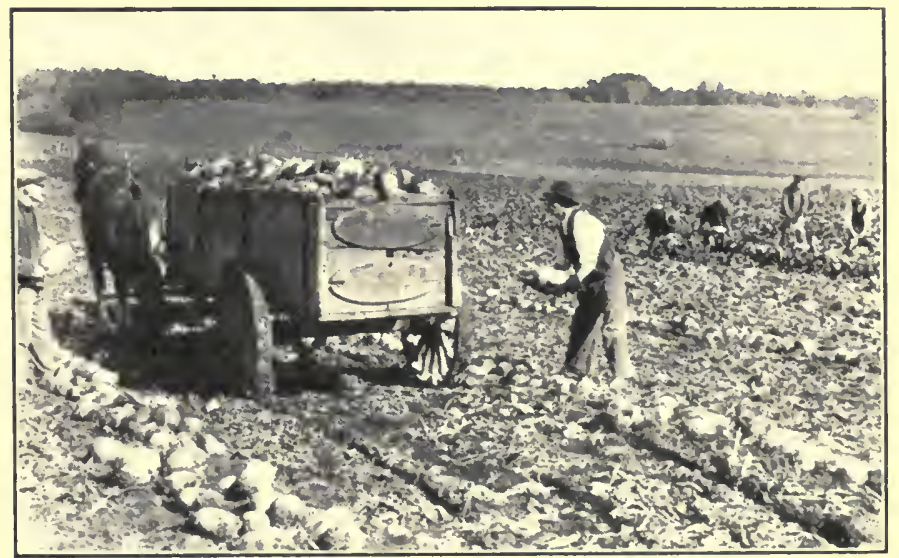

Fig. 68.-Harvesting Mangels in Manitoba.

ity as a conseduence and eost me double what it should have to harvest it", and still another", "I plowed my fallow early in .June and it kept my teams busy all summer cultivating it to keep down the weeds; I prefere to do it later because the weeds don't grow so mureh and it takes less horse powere and time to keep it bark-1 resduee the rost of fallowing hy doing it later", and another, "The maintenance of a mulch as a means of lessoning evaporation does not pay muless there alre wereds to be killed at the same time."

141. Defense of Fallowing.-One or more of the objecetions mentioned may berome serious faults of fallowing 
in some areas and on some soil types in oceasional years. The fallow either in an extreme or modified form may, however, be defended in spite. of its numerous shortcomings.

If frost euts down the yield or quality of the erop, the eause of the low yield is not the shortage of water but the shortage of heat, in which ease the practices of "northern farming", those that promote early maturity, should be given first eonsideration, and not the practices of dry farming which are primarily concerned with controlling the moisture supply. Among the methods of northern farming may be mentioned: the use of early classes of grain, early maturing varieties within the class, early seeding, thick seeding, packing the land, less frequent fallowing, later and shallower plowing of the fallow, and the use of frost resistant crops.

If it isn't 'good business' to let the fallow field be 'idle' then it should be eropped. But one should first be sure it is not good business. It frequently does not pay on heavy, moist lands and on some soils that blow, but under present economic conditions it is good business in the warmer seetions of the dry parts of the West that are not subject to early fall frosts. When land becomes more expensive and capital, equipment and Labor less costly some substitute such as eorn or a pasture fallow may be used where it ean be grown and utilized satisfactorily. It is possible that in some sections the time for a change has come.

If the fallow dissipates organie matter and nitrogenand it does to a very serious degree-then we shall have to dissipate organic matter and nitrogen until we find a better way, because we must have water in the soil and the fallow is the best way to get it there. As soon as 
organic matter and nitrogen and not water commence to limit the yield of erops, we shall have to restore them to the soil. Most men recognize this serious objection to fallowing, but before dispensing with the fallow they want to be shown a better way. It is to be hoped therefore that on all soil types eareful tests of organie fertilizers (such as manure) and the use of legume crops (nitrogen gatherers) may be conducted from time to time in order that we may know, for each of the different types of soil, whether the use of any or all of these means of improvement will pay.

If crops require 250 to 1,000 pounds of water per pound of dry matter produced, and if the function of

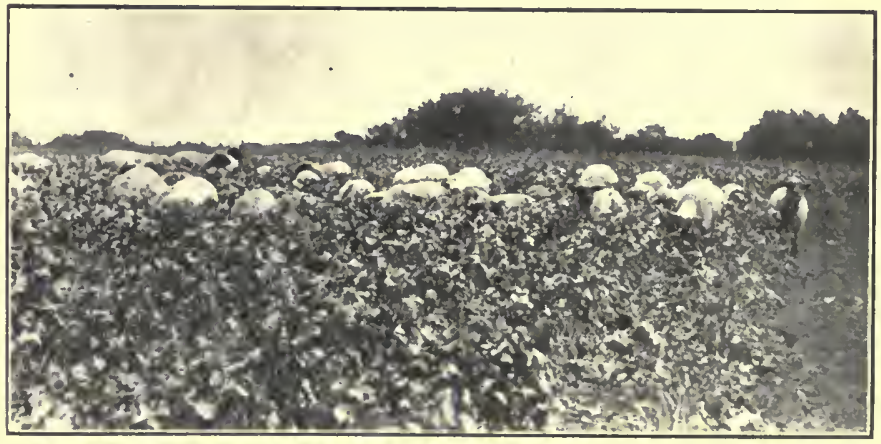

Fig. 69.-Sheep Pasturing in Rape.

the fallow is to store and conserve water, then neither grass nor even hoed arops will replace the fallow, even though erops be rotated; but both, and particularly the hoed erops, will lessen the frecpueney of the fallow. The yield of wheat on corn ground at many different points has equalled the yield on fallow. Wherever this is true, and wherever the corn ean be grown at no loss, or even 
at a loss smaller than the cost of the fallow, it will eventnally supersede the fallow. In the meantime two faetors must be dotermined for each part of the country, (1) the relative yield on fallow and corn ground, and (2) the relation of loss or gain on the corn to the cost of fallowing. The method that gives the greatest net returu should eventually enter into general farm practice.

If drifting soil interferes with the development of the crop, then the drifting soil needs greater attention than the fallow. Excessire harrowing should be lessened or dispensed with altogether and 'organic matter', 'lummus', 'poot fiber', the substances that were in the land when it did not blow, should be put back. To lessen blowing it may be found advisable to grow a thin cover erop or' pasture crop on the fallow, to grow winter rye, or in extreme cases, to seed the land down to hay. But after any or all of these it will still be necessary to practise summerfallowing or a modification of it occasionally on our drier soils.

The plowing moder of mgerminated weed seed should never be practised. Every effort shomld be made to eause the early germination of weed seeds. Early fall disking or shallow plowing will help to do this, but if in very dry seasons the seeds do not start it would be wise to delay plowing the fallow a short time in order to give them opportmity to do so. If on aceount of the presenee of ungerminated seeds the plowing of the fallow be delaved, it should be disked and then plowed at a later time.

If the crop on fallow grows too rank and 'lodges' ol' too late and suffers from frost, then one should tonsider whether he should not fallow less frepuently or plow shallower or later, or whether the pastured fallow 
would not be best. The practices recommented are for extremely dry conditions and not for all areas irrespeetive of elimatic conditions.

If weeds grow more luxuriantly on an early fallow and the cost of keeping them down is thereby increasedit is but nature's evidence that such a fallow is achieving

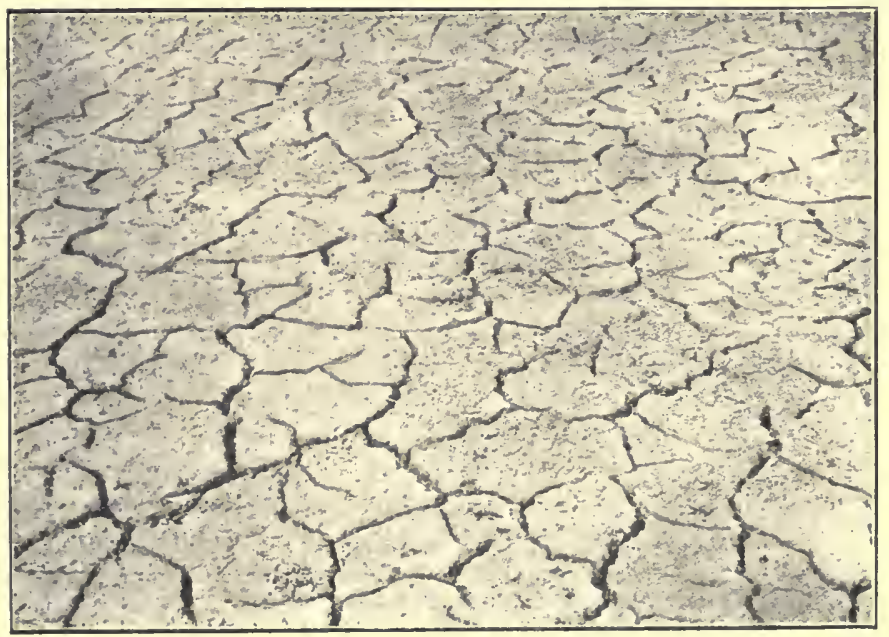

Fig. 70.-Cracks in Heavy Land.

These inerease the evaporating surface of the soil.

its legitimate function-the storage and conservation of soil moisture. The eost of the added eultivation is, of course, an extra charge against the fallow. When this is necessarily exeessive and particularly on soils that are inclined to blow it is often advisable to delay the plowing. If this is dome, howerere, steps should be taken to prevent an excessive weed growth which wastes moisture, and to keep the soil loose on top and reseptive to rains. There is some evidence that if such steps are taken, 
early plowing is not essential. Under other conditions where the moisture supply limits the yicld of crops it has yet to be demonstrated that early fallowing, even at a greater cost, does not pay.

There is but little doubt that.under humid eonditions soil mulehes lessen evaporation. Whether it pays under dry conditions to harrow or eultivate in the absence of weeds is another question. Many farmers as well as investigators believe in intensive methods for the eonservation of soil moisture, but some recent investigations go to show that if sufficient cultivation is given to prevent weed growth and to prevent the soil from baking or eracking, additional tillage to save moisture by mulching is not likely to conserve enough to pay for the extra work.

142. General Conclusions.-In conclusion, then, the dry lands of earlier days are produeing crops because men have found out how to get moisture into the land and keep it there at not too great a cost. They "store" it (1) by letting the soil lie idle one year in two or three, or four or five, as neeessary, and (2) by putting it, early in the rainy season, in such a condition that it will absorb the rains that fall and not let them "l'un off" the surface. This is done by plowing, usually in June or early July. The moisture is eonserved after it has been "stored" by controlling weed growth, and by lessening "evaporation", the two things which dissipate moisture from the soil. Weed growth is controlled by timely and suitable tillage with luarrows, dises and cultivators. If this tillage for weed control does not also control evaporation suffieiently it is questionable whether extra work with this object in view will pay except on soils that bake, or where land has been freshly plowed. 
To be most effective a fallow should be surface eultivated the fall before, plowed in June or early July in the drier parts and as late as early August in the Red River Valley; on some soils it should be harrowed immediately after plowing, and surface eultivated as neeessary (1) to control weeds, (2) to prevent the soil from baking or eracking, and (3) to have the soil firm to within two or three inches of the surface. In regions where the rainfall is greater and where fall frosts are likely to do damage, such extreme practices as result in later maturity of seed erops should be modified in order to meet the more humid and colder conditions found. On soils that drift the surface tillage must be such as will conserve moisture and kill weeds without making the surface too fine and dusty. On heavy soils where the (aro frequently lodges later plowing of the fallow $\mathrm{rr}$ the use of a pasture erop on it is desirable. On fields eontaining mueh quaek or other ereeping-rooted grasses twice plowing may be desirable-onee shallow in the fall and then deeper the next season, or once early in June and again later in the summer.

The frequeney of the fallow may be lessened by the use of intertilled erops, the practice of suitable rotations, the maintenance of the humus content of soils and by a more intensive agrieulture, but these are not likely to replace it or a modifleation of it in the drier parts of the prairies until land is more expensive and labor, eapital and equipment cheaper.

At present the fallow or corn is absolutely essential in southwestern Saskatchewan and southern Alberta; a fallow is to be desired oceasionally in all the prairie region west of central Manitoba; but it need be less frequent in the park belt and only very oceasionally 
lractised in the wooded areas and in eastern Manitoba. Indeed, on some of the richer soils in the more humid sections it may, muder good management, be practically dispensed with.

The fact that the fallow dissipates the two most valuable constituents of fertile soil, viz., organic matter and

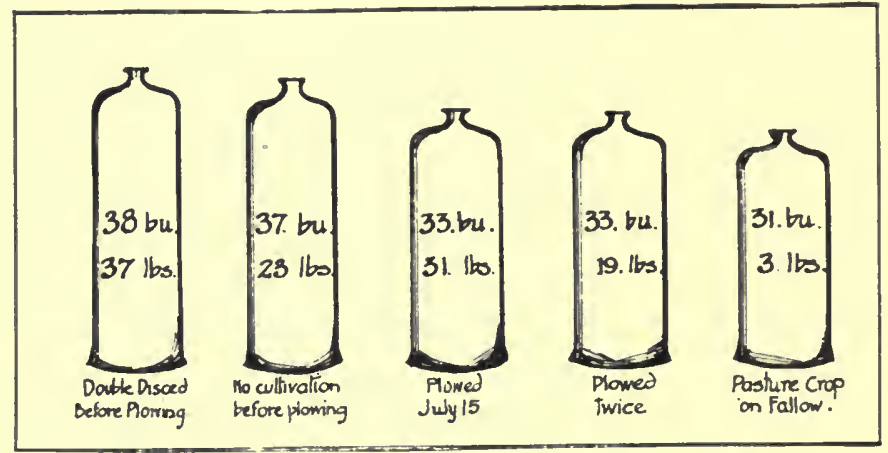

Fig. 71.-Summary of Tillage Tests on Fallow Land at Saskatoon.

nitrogen is a matter of serious concern. It means that subsequently these will have to be maintained in the soil by the return of manure or fertilizers or by plowing under legume erops.

There is little doubt but that as time goes on modifications of the present system will be found that will suit many conditions in the Canadian West better than the present general practice. Sologlnums are more or less completely replacing the fallow in the drier states and corn in the northern states. Even in parts of Manitoba corn is now being useel as a substitute for the fallow, and on some soils in the very dry parts of Alberta and Saskatchewan this crop offer's considerable promise for the future. The use of such a hoed crop carries with 
it most of the advantages of a fallow since it makes possible the storing of moisture, the killing of weeds, and the developing of available plant food. Other praetices that offer some promise as partial substitutes for the fallow are (1) sunflowers planted in wide rows, (2) potatoes and roots, (3) the early breaking of grass land, and (4) the plowing in late summer or early fall of land sown to eereals and eut early for hay or other purpose.

The advantages gained in the better hay and pasture areas by the early "breaking" of grass lands, or by the later summer plowing of land sown to early maturing feed erops make these practices fairly eomparable in effeet to the fallow at least in the more humid parts; while the introduction and use of intertilled crops, such as corn, where it does well, of grain crops such as Western Rye, Brome and Timothy, and of legume crops like Alfalfa and Sweet Clover, cffers some promise of enabling us to develop a system that will have the chief advantages of the fallow without at the same time dissipating organic matter and nitrogen so rapidly. 


\section{('IIAP'IER XI. \\ CROP ROTATIONS}

143. What a Crop Rotation is. - A crop rotation is a more or less regular succession of erops of different kinds on a given field or farm, designed to result in a larger net return or some improvement of the soil.

In the older agricultural areas the erop rotations always make liberal use of leguminous erops. In fact, no rotation is considered rational that does not include them. The ancient Romans appreciated the value of legumes for the effeet upon the soil and suceeding erops. Writing in the first century A. D., Columella said, "Where no kind of manure is to be had-the enltivation of lupines (legume plants) will be found the readiest and best substitute." At an earlier date Saserna wrote, "Some of the leguminous plants manure the soil and make it fruitful, whilst other crops exhaust it and make it barren."

144. The World's Best Evidence on Rotations.-The best information the modern world affords of the value of suitable crop rotations is to be found in (a) the results of the long and aceurately conducted tests at Rothamsted in England and at different places in America, and (b) the practice of erop rotations in all the old agrienltural regions of the world. 
Wheat grown continuously at Rothamsted, England, for sixty years has produced an average yield of 14 bus. per aere. On adjoining land in a rotation of turnips, barley, clover and wheat, the wheat produeed an average yield during the same time of 25 bus. In the same rotation barley yielded almost 25 bus. per acre while on a continuously cropped plot it yielded only a fraction

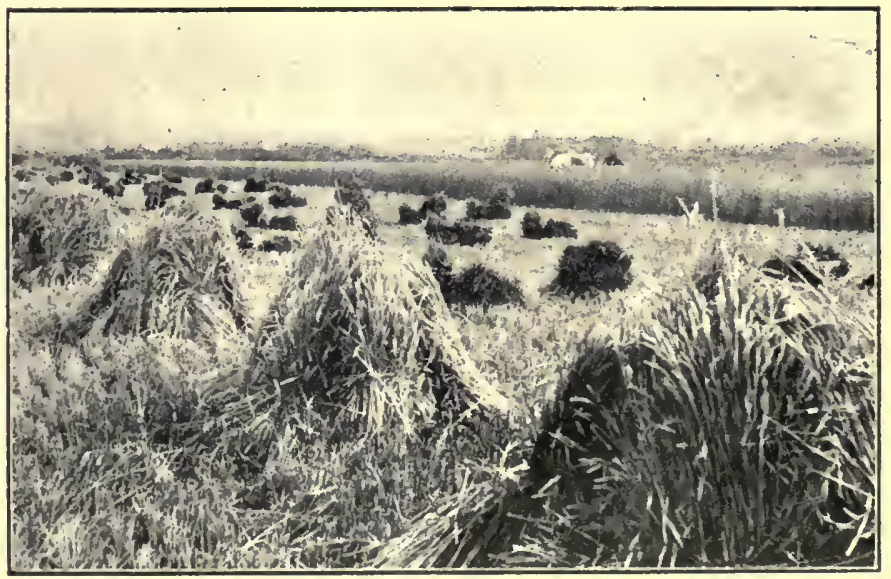

Fig. 72.-Wheat After Alfalfa on Brandon Experimental Farm.

over 14 bus. During the last 20 years of the sixty-year period wheat in the rotation averaged 24 bus. while on the continuously eropped land it averaged only 12 bus. This is probably the best information the world affords on the relative values of a good erop rotation and continuous cropping.

Corn grown eontinuously at Urbana, 1ll., for 29 years produced an average yield of 27 bus. On adjoining land in a rotation of eorn and oats it gave an average of 46 bus., while in a rotation of corn, oats and elover 
the average yield of eorn was 58 bus. per acre. This is the oldest experiment of this kind on the eontinent of Ameriea and the evidence it provides as to the value of a suitable crop rotation may well be taken to heart by all students interested in the development of a permanent and profitable agrienlture.

The arerage vicld from wheat grown continuously for 13) years on the rich Red River Valley soil of North Dakota at Fargo was 13 bus. 8 lbs. per aere, while the average yield of the same erop in all the different rotations under test for the same length of time and under the same conditions was 19 bus. 8 lbs. This is the nearest to Western Canada of any rotation test that has been condueted for more than a few years. The soil and climatic conditions at Fargo are not very different from those in the Red River Valley of Manitoba. The data seeured at Fargo emphasize the fact that even on our relatively new soils eontinuous cropping for a few years results in a considerable decrease in the productive power of the soil, and the result should not be disregarded by the students of Western Cauadian agriculture.

In China and .Japan where the land has been eropped longer probably than in any other part of the world a rotation is always practised, and it always includes a legume erop, generally the soy bean. In Italy, where agriculture is very intensive, a erop rotation including loume erops has been practised for many centuries. In England, Germany and France and all of the other agricultural regions of Europe more or less systematic rotations are the rule. In the corn belt of America the onecrop system is fast griving way to a rotation including an intertilled rop, a grain erop and a legume erop) (elover 
and soy beans or cow peas.) In Ontario the eontinuous growing of hay in some parts and wheat in others has practically disappeared until now a hoed erop, a grain erop, a hay erop and a pasture crop follow one another in the order named on nearly every farm.

The above data are among the best available on the value of succession eropping as compared with the continuous use of one erop on the same land. The brief summary is not fair to the continuous method sinee in the suceession plan the erops other than wheat are not neeessarily as valuable as wheat. Yet the relative yields are so vastly different that none will attempt to say the practices that produced the larger ones are not by far the better for the countries where the tests were made.

145. Results of Tests at Saskatoon and Brandon.- The influence of the preceding erop on the yield at Saskatoon was studied during the years 1915, 1916 and 1917 with the following results :-

'TAnLE XVII.-Showing results of three years' tests at Saskatoun of the influence of preceding crop on the yield.

\begin{tabular}{|c|c|c|c|c|c|c|c|}
\hline & & $\begin{array}{c}\text { Av.yield } \\
\text { wheat }\end{array}$ & $\begin{array}{l}\text { Av.yield } \\
\text { oats }\end{array}$ & $\begin{array}{c}\text { Av.yield } \\
\text { barley }\end{array}$ & $\begin{array}{c}\text { Av.yield } \\
\text { rye }\end{array}$ & $\begin{array}{l}\text { Av.yield } \\
\text { flax }\end{array}$ & $\begin{array}{c}\text { Av.yield } \\
\text { peas }\end{array}$ \\
\hline$r$ & & & $\begin{array}{l}\text { bus } .1 \mathrm{bs} . \\
64-24\end{array}$ & & $\begin{array}{l}\text { bus.lbs. } \\
22-14\end{array}$ & $\begin{array}{l}\text { bus. Jbs. } \\
15-31\end{array}$ & bus.lbs. \\
\hline & & 2 & $62-$ & 38 & $24-06$ & 14 & $20-33$ \\
\hline “. & Po & $28-3$ & $68-2$ & & 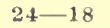 & $17-$ & $20-17$ \\
\hline “. & and & & & & & & \\
\hline “. & & & & & 2 & 16 & 1 \\
\hline “. & Cor & 35 & $71-2$ & $6-3$ & $26-35$ & -42 & $22-14$ \\
\hline “. & Fallow .. & $33-02$ & $77-07$ & $39-33$ & $27-42$ & $14-55 \dagger$ & $23-35$ \\
\hline
\end{tabular}

The test has been under way only three years and the data are not therefore conclusive. Nevertheless it

* In the early years of the project half of this plot was planted to turnips and swedes and half to potatoes. In 1917 and 1918 one plot was provided and the yield of all crops was very much higher on the potato ground than on the turnip ground.

F Flax did not mature satisfactorily on fallow in 1915 hence the low average yicld. 
emphasizes the value of intertilled erops such as eorn and potatoes, and sueh leguminous erops as peas. The effect of pereunial legume and grass erops was studied only in the year 1917 when the yield of every erop was greater after these than after any annual crop or on fallow. In this test the alfalfa land yielded slightly more than the grass land.

The following yields are reported from trials made with wheat at the Brandon Experimental Farm in 1915 :- After alfalfa 61 bus. 10 lbs.; after red elover 58 bus. 30 lbs.; after alsike clover 57 bus. 40 lbs.; after western rye grass 49 bus. 40 lbs.; after red top 47 bus. 20 lbs.; after timothy 43 bus. 60 lbs.; after Kentueky blue 38 bus.; after brome grass 29 bus. $20 \mathrm{lbs}$.

\section{Advantages of Suitable Crop Rotations.-(1) A} rotation ineluding different erops reduees the risk of a complete failure. In this elimate where drought, frost or hail oceasionally causes a partial or complete loss of the grain erop a greater diversification of erops is less likely to result in serious loss than where only one elass of erops is grown. This is partienlarly true where forage erops are used and where live stock is kept.

(2) A good rotation aids in fighting weeds. When grain erops only are grown, certain weeds, sueh as wild oats and mustard, that ripen earlier than the grain, spread rapidly. When hay crops only are grown eertain perennial weeds, such as thistles and daisies, have opportunity to spread. If grass and cereals are alternated, and particularly if a fallow or an intertilled erop is added, all of these weeds ean be more easily controlled. The use of perennial grasses for hay has in many parts proven a very effieient means of controlling wild oats. 
(3) Some crops increase the organic matter of the soil. The roots of grass crops are much more extensive, at least in the surface soil, than those of the grain crops. The grass forms a "sod", the grain crops, a stubble. Brome grass has some disadvantages, but it adds more root fiber to a soil than any of our other erops. Western rye grass and timothy add root fiber also, but much less than brome.

(4) Some crops increase the nitrogen as well as the organic matter of the soil. Legume crops such as alfalfa, sweet clover, red clover and peas, if inoculated, may leave the soil richer in nitrogen than bcfore they were grown. Crops with large fleshy roots like alfalfa and sweet clover also add much organie matter to the soil. If a quarter of the land is occupied by one of these crops, and the stubble and roots plowed under, and if an oceasional catch crop of some similar legume is plowed under, it is possible to maintain the nitrogen and organic matter content of the soil.

(5) Changing erops lessens plant diseases. Certain diseases such as flax wilt, potato scab and clover sickness are earried over in the soil. These diseases may cause a partial failure in the erops upon which they prey, but have no effect upon other elasses of erops. By practising a rotation all may be grown upon the same farm with little danger from this cause.

(6) Suitable rotations may lessen soil drifting (1) by having the ground covered with a growing erop at the season when drifting occurs or (2) by increasing the cohesive power of the soil. Soil drifting is usually most serious here in May. If the ground is covered with grass or other hay erops, or even winter rye, it will be protected. If the soil is rich in organic matter, as after a 
grass crop, the particles will be so held together by the "root fiber" that little or no blowing will take place.

(7) Different plants draw nourishment from different depths of soil. The grasses and eereals are considered to be shallow feeding erops. Alfalfa, sweet clover and turnips are deep feeders. 'The use of both

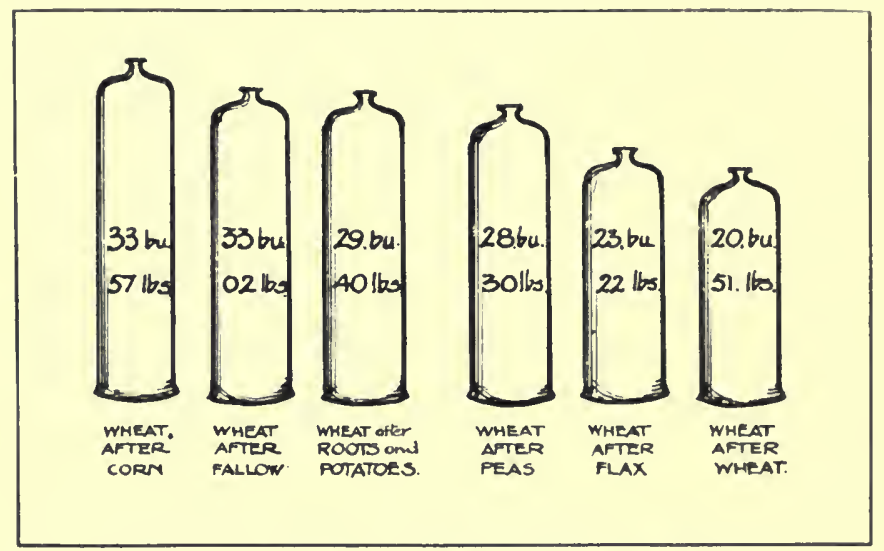

Fig. 73.- Summary of Rotation Tests at Saskatoon.

types of erops inereases the feeding ground and makes possible the utilization of the soil to better advantage.

(8) $\Lambda$ good erop rotation systematizes the farm work. In a good rotation the fields are approximately the same size, ${ }^{*}$ the amount of each kind of work is about the same each year, and each season of the year; and the labor and power requirements do not vary from season to season and can be more easily and aecurately estimated and provided for beforehand.

* On more or less broken land fields of uniform size and grood shape may be imposible to arrange. This, of course, is not an essential, although a very desirable condition when practicable. 
(9) A well planned rotation may result in a better distribution of labor. At present our labor requirements at harvest time are large and at other seasons of the year small. Until some modifieation of our present system of eropping is made, this difficulty will increase rather than diminish. The use of more crops might distribute the harvest season from the last week in Jume to October whereas now the grain crop harvest is practi cally confined to the six weeks between August 15th and the end of September. If biennial or peremnial erops are grown instead of some of the amnuals, the acreage to be prepared each year is less, the seed may often be sown with a grain erop, the period of harvesting is prolonged, and the stock may aid in harvesting, thus lessening the labor required. Some provision for winter work must also be makle if this problem is not to be a permanent one. What work will ultimately be provided is not clear, but some form of live stock enterprise seems the most promising.

(10) Continuous cropping is reported to result in the development of poisonous substances in the soil. Recent investigations have been interpreted as showing that when one erop is grown contimuously on a piece of land, the soil becomes toxie or more or less poisonous to that particular erop. It is offered in explanation that the roots give off substances which are poisonous to the plants. It is stated that these substances ane not poisonous to other kinds of erops and that by changing from one crop to another the ill effecots are not found.

147. Requirements of Rotations in Western Canada.Under our present system of farming not only is the risk of partial failure very great but the organie matter of the soil is decreasing, soil drifting is increasing, plant 
food materials are being dissipated, weeds and inseet pests are beeoming more prevalent, and on all exeept the very richest and deepest types of soil the productive power of the land is going down.

These results of continuous eropping are not peeuliar to Western Canada. One or more of them have been observed in every old agrieultural region where the continuous use of one crop or one elass of erop has proceeded for any length of time. Its ill effects may be seen to-day in the hay fields of old Ontario, in the tobaeeo fields of Virginia, in the cotton region of the South, in the eorn belt of the central States and in the wheat areas of the northwestern States. In the early history of eaeh of these regions the one erop that did best was grown to the exelusion of all others beeause it gave better returns. In the end the evils of the system came to outweigh its advantages and a ehange to suitable rotations had to come about. In the pioneering stage of development in the prairie and park belt region of the West, grain growing is perhaps a necessary and a profitable praetice, even though in some places and in some seasons it is attended by considerable risk. When settlers eome with little eapital they must first make more eapital before they ean get the equipment neeessary to practise a better system. This eapital under present economic conditions must come very largely from selling the stored fertility of our eheap land. To this extent the praetiee of continuous grain growing is justifiable, but after the capital is available for buildings, fenees, a water supply and stoek, some provision for establishing a less wasteful system should be made.

148. Difficulties in Establishing Good Rotations in the West.-(1) The chief immediate difficulty is the eost of 
the neeessary fences, buildings and stock. As a rule most pioneers are not eapitalists, and until they ean make some money they eannot undertake the improvements they would like to make. This, of course, is only a temporary objection, but under some unfavorable soil or elimatie eonditions might become permanent, in which ease state eo-operation in the way of cheap loans for necessary permanent improvements might well be considered.

The praetice of loaning money to farmers for development purposes for a long period of years at a low rate of interest on the amortization plan has some objectionable features, but as a means of developing and at the same time conserving our soil resources it is one of the most statesmanlike measures that has ever been taken by any of our local legislatures. In this way the state may aid in conserving its own resourees, and unless it does this and more, the state rather than the settler must be held responsible for sueh uneeonomie praetiees as the individual farmer may find himself foreed to pursue.

(2) Delayed returns is another difficulty. The grain grower waits only a year for his eash erop. The mixed farmer waits a year for a portion of his erop, then perhaps feeds it to live stoek, sometimes waiting two years or more before selling. The delayed returns enforec eeonomy and result in greater savings, but in some eases at least, the savings are too dearly bought. The delayed return is not a serious objection to rotation practice but is a considerable diffieulty with the pioneer or the man who is deeply in debt.

(3) The low yield of hay under prairie conditions does not eneourage its use. The favorable effect of hay crops on the maintenanee of organie matter and the con- 
trol of reeds, suggests the need for them in any good rotation. Unfortunately, under dry conditions these erops are often so low in yield that in the drier prairie areas men will not grow them until foreed to do so by drifting soil or by weeds.

(4) The lack of a suitable legume is a hindrance to good rotations in many parts. Alfalfas hardy enough to

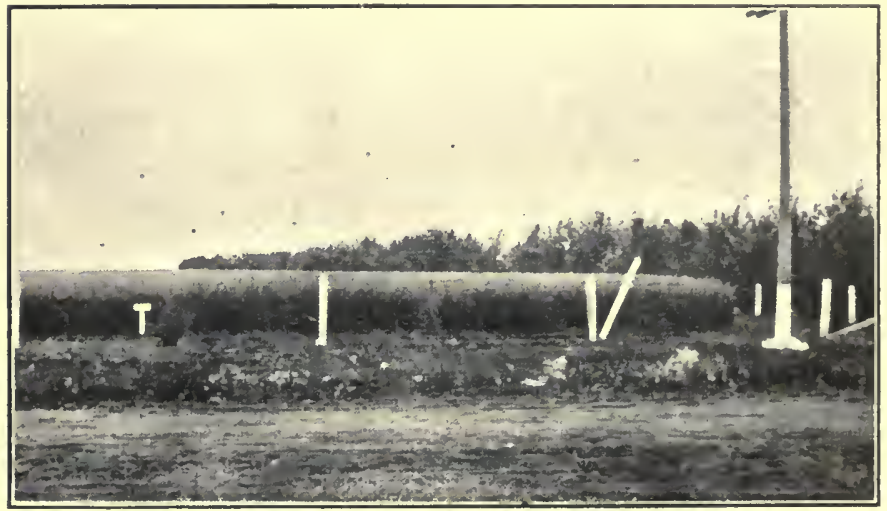

Fig. 74.-Oats on Irrigated Alfalfa Sod.

- Courtesy Department of Interior.

withstand the prairie winter are now available for all exeept the higher altitudes. But the erop is so expensive to get under way, and vields so little in dry years and is so difficult to break up that it is not a good rotation erop. Peas do well in the more moist regions but suffer from drought in the dry belt and from fall frosts in the north. Red clover is not hardy enough for eommereial use, except in favored areas and in mixtures of grass. Sweet elover seems now to offer the greatest promise as a rotation legume for the prairies. Hardy strains of red elover may be found satisfactory in the 
park belt, but this has not yet been conelusively demonstrated. Alfalfa promises much under irrigation, and alsike clover also seems to offer some possibilities there.

(5) The lack of an intertilled crop suited to all conditions is another difficulty. The hoed crop of Ontario, the corn belt, and the northern States is corn, that of England is turnips. In the warmer parts of the West on warn soils corr promises much as a forage erop, iout in the higher altitudes and northern latitudes, partieularly on the heavy soils, its future is not promising. Turnips and other root crops can be grown where corn is unsuited, bat the labor cost under present conditicns is too high to make a large acreage a commercial snicess. There is now no doubt but that corn will have a permanent place in the eropping system of the southern parts of Manitoba, Saskatchewan and Alberta, but unless economic conditions change, the acreage of roots will never becone large enough to make this type of plant an important factor as a rotation crop. The same is largely true of potatoes. Rape has been grown in enltivated rows for pasture in a rery large way by some farmers, but this praetice has not developed to any extent. With dense population and cheaper labor these crops, and sunflowers as well, may find a larger place in Westeru rotations.

149. Classes of Crops used in Rotations.-The crops used in all good rotations may be divided into four elasses: (1) eash erops, (2) intertilled erops or hoed erops, (3) legume erops or nitrogen gatherers and (4) grass crops.

The chief cash crops of this comtry are the grain erops-wheat, oats, barley and rye-and flax, although liay and potatoes are also grown as money rops in some plaees. The most important intertilled crops are corn, 
potatoes and roots. The most suitable legume crops are alfalfa, sweet clover (red clover in some areas) and peas, while Western rye grass, brome grass and timothy are the best grasses.

'The grain erops lessen plant food and organic matter, return nothing to the soil and permit anmual weeds to flourish. The intertilled crops remove plant food and very greatly lessen organic matter but the intertillage they require conserves moisture, develops available plant food and aids in weed control. The legume erops feed heavily upon mineral plant food elements but will maintain or increase the nitrogen supply if grown frequently enough. The grass crops use up plant food but increase the root fiber or organic matter in the soil, and by oceupying it for a year or more tend to smother out annual weeds.

150. Planning a Rotation.-The establishing of suitable rotations in all new agrieultural eountries has been a slow process. So many different factors enter into the problem that the eonservative farmer prefers to let some one else do the testing, at least so long as his present methods are profitable. Chief among the factors that must be considered when one is planning a rotation are :-

1. The need that exists for improving one's own soil conditions and controlling weeds.

2. The future requirements of the soil from the fertility standpoint.

3. The partienlar effect of different classes of erops on the land.

4. The relative suitability of different classes of crops to the climatic and soil conditions that obtain in the district. 
5. The economic distribution of labor thronghout the year.

6. The extent to which financial eonsiderations make necessary the growing of eash crops.

7. The availability and cost of eapital.

8. The extent to which the rotation is likely to lessen the risk of farming and insure eommensurate retnrns for the extra investment required.

151. Some Well known Rotations.-The most common rotation in England is turnips, grain, clover and grain; the old Norfolk rotation of Rothamsted is turnips, barley, clover and wheat.

The most common rotation of Ontario and the mixed farming distriets of the northeastern States is hoed erop, grain, hay and pasture, although many modifieations of this are practised. Corn, oats, hay (timothy and red (lover) and pasture is the chief rotation of the stockgrowing and dairying distriets.

In the eorn belt of the United States, corn often alternates with oats, but the best rotation from the point of view of soil productiveness is one or two erops of corn followed by oats and then elover.

In the spring wheat regions of the Great Plains Region of America the pioneer rotation is fallow followed by grain for two or three years. In the northwestern States this is generally giving way to corn followed by two or three grain crops. In the Sonthern Great Plains Region the sorghums are gradually replaeing the fallow, while in the Prairie Provinees of Canada no improvement in the original fallow and grain rotation has yet established itself, although several modifications of it are in a fair way to do so in some parts. 
152. Rotations now used in the West.-The cropping systems now followed in the Canadian West vary in different parts. The following are some of the most commion:-

1. Fallow, wheat, and wheat or oats. This rotation is used in the drier parts of the prairie area. In the extremely dry areas a few men fallow the land every seeond year.

2. Fallow, wheat, wheat, and oats or barley-used in the more moist parts of the prairies.

3. Fallow, oats, wheat, oats, and barley-used in the ligher altitudes or northern areas of prairie or park belt where the frost-free period is somewhat shorter than in the southern part of the prairie belt.

4. Oats and barley for hay, wheat, wheat, oats or barley-used in the more humid short season parts where the fallow erop is often too late to be profitable.

5. Fallow or breaking, wheat, oats, hay, pasture-used to some extent in mixed farming areas where the preeipitation is low.

The rotations of the future for the prairie areas must include a grain crop, a legume erop, and a fallow, or where it ean be profitably grown, an intertilled erop. In the early years at least they will neeessarily inelude one or more cash crops.

What the eash erops will be, elimate and soil conditions will determine. Wheat, oats, barley and rye, in some areas flax, and in some alfalfa, timothy and potatoes may be used. The grass crops will likely be eonfined to Western rye grass, brome grass and timothy, although some Kentucky blue grass, red top and meadow feseue may be grown. The most profitable legrume crops for short rotations are sweet clover and peas, and for long 
rotations, alfalfa. The most promising intertilled erop in the South is corn. No hoed erop suited to large acreages is available for the North, although a small acreage of roots and sunflowers may very profitably be grown in this area.

153. Rotation Tests at Brandon.-The general conelusions from eight years' work with different crop rotations at the Experimental Farm at Brandon have been summarized by Mr. W. C. MeKilllican, the Superintendent of the Farm, in a discussion of the rotations known as "E", "F", "G", "H", "I" and "W" as follows:"The rotations under test at Brandon are as follows:-

154. "Typical Grain Farming Rotations.-

$$
\begin{aligned}
& \text { Rotation "E":- } \\
& \text { 1st year-Wheat. } \\
& \text { 2nd year-Wheat. } \\
& \text { 3rd year-Oats. } \\
& \text { 4th year-Fallow. }
\end{aligned}
$$

"This is the typical grain farming rotation of Manitoba. No manure is applied at any time. This rotation has the fallow for a cleaning season, has three cash erops, but no fodder crop unless the oats are used in that way, and no leguminous crop. By means of the fallow it conserves moisture and makes plant food more readily available for the erop that follows, and attempts at least to eontrol weeds. It makes no attempt to return anything to the soil, so that gradual depletion and inereased tendency to blow are the inevitable results. I) uring the time that prairie soils are giving up their virgin fertility, good results are obtained from this rotation, but it cannot continue indefinitely.

$$
\text { Rotation "D":- }
$$

"This rotation has exactly the same order of crops as 
"E", but has this difference, that once in four years an application of manure is given. This manure shonld help to keep the soil from less rapid exhaustion than where there is none applied. However, in the actual results at Brandon the increased returus from the mamure have not as yet been sufficiently great to pay for the cost of application. It is expected that greater comparative returns from the manure will be obtained after the eumulative results of longer application are felt.

\title{
155. "A Well Balanced Rotation.-
}

\author{
Rotation "F":- \\ 1st year-Wheat. \\ 2nd year-Wheat. \\ 3rd year-Corn. \\ 4th year-Oats or barley (seeded \\ down). \\ 5 th year-Hay (elover and grasses).
}

"This rotation fills the requirements as well as any for Manitoba eonditions. Two erops of wheat and one of oats or barley place a good proportion (three-fifths) of the land in grain, which is the eash erop of Manitoba. The year of eorn provides a eleaning season and also a large amount of fodder. 'The year of hay adds to the fodder supply and ineludes a leguminous erop. The hay land plowed in July and well enltivated makes a rery good preparation for wheat. The corn land makes a good preparation for oats or barley and also for the grass seed sown with these erops. The proportion of corn is too large for most Manitoba farms, but this could be redueed in actual practice by having the field partly in corn and partly in summerfallow. Manure is applied before the corn crop in this rotation. 
"This rotation has given very good results at Brandon. Not only does it provide for the maintenance of the soil, but it is giving greater returns at present than either rotation "E" or "D". The average profit of this rota. tion for the five years-1914-1918-was 81 per cent. greater than that obtained from " $\mathrm{E}$ " the straight grain growing rotation.

156. "The Most Profitable Rotation at Brandon.":-

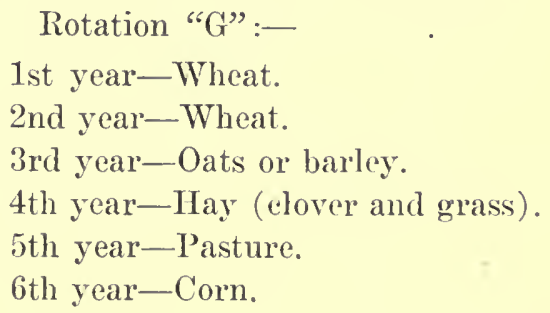

"This rotation is somewhat similar in eharacter to the last one. It includes the same kinds of erops, but changes the order somewhat, the wheat coming after the corn instead of after the hay and the coarse grain erop following the wheat instead of coming after the corn. This arrangement makes an exeellent and extremely profitable wheat crop, but it gives less suitable eonditions for seeding down. It gives better eonditions for corn (on sod) than the other where the corn follows the wheat. It has a year of pasture and in that differs from

* Writing of this rotation at the Scott Experimental Farm in Western Saskatehewan, Superintendent 'Iinline says: "While the profits from the bay are not large, and the pasture barely pays expenses, yet the increased profits from the succeeding grain erops, together with the decreased cost of keeping weeds inder control, f.as made this rotation musually profitable. 'The average net profit for the past four years amounted to $\$ 7.88$ per aere as compared with \$5.16 from the grain rotation-fallow, wheat, and wheat." 
"F" which makes no provision for pasture. Mannre is applied for corn as in " $\mathrm{F}$ ".

"This rotation has also given good results at Brandon: Its average profit for five years exeels that of the straight grain growing rotation by 155 per eent.; it has been the most profitable rotation tried on the farm. However, seeding down with the third erop of grain would not be successful in all parts of Manitoba and that feature might rule it out in some places. The large proportion of eorn would also have to be modified in actual farm practice as in the preeeding rotation.

\section{7. "Rotations without Corn.-}

Rotation "H":-

1st year-Wheat.

2nd year-Wheat.

$3 r$ year-Fallow.

4th year-Oats.

5 th year-Hay (clover and grass).

6th year-Pasture; and-

Rotation " $\mathrm{I}$ ":-

1st year-Flax.

2nd year-Oats.

3 rd year-Fallow.

4th year-Wheat.

jth year-Hay (elover and grass).

6 th year-Pasture.

"These two rotations are very similar in type, the only difference being a change from wheat to flax as the first crop and the interchanging of the wheat and oat crops. They differ from " $F$ " and "G", in that they do not inelude corn, but keep to the summerfallow as the means of cleaning the land. They inelude fodder and leguminous crops and are therefore more permanent in 
their character than rotations "E" and "D". Manure is applied on the pasture and plowed in.

"These rotations have been more profitable than "E" and "D", but not so profitable as " $F$ " and "G". On the other hand, the absenee of corn makes the labor problem more easily handled than where corn is largely grown. Taking "E" as the standard again, rotation " $\mathrm{H}$ " has beaten its profits on a five-year average by 49 per cent., and rotation "I" has done a little better.

158. "A Rotation for a Dairy or Stock Farm.-

Rotation "W":-

1 st year-Wheat.

2nd year-Wheat.

3rd year-Corn.

4th year-Oats.

5 th year-Barley.

6 th year-Alfalfa (sown alone).

7th year-Alfalfa.

Sth year-Alfalfa.

9th year-Alfalfa.

10th rear-Alfalfa plowed up after first eutting.

"This rotation is not intended for the ordinary mixed farm but for a dairy or pure-bred stock farm where the production of a large amount of high class fodder is more important than wheat. It includes all the requirements of a permanent rotation and slould build up the fertility of the land more than any of the others. Manure is applied twice in the cireuit, for corn, and as a top dressing on alfalfa.

"IBeing so long, it has not got a proper start as compared to the other rotations. Its profit per acre for the 
same five years exceed " $\mathrm{E}$ " by 145 per cent., being seeond only to rotation "G" in profitableness. The indications are that it will soon take the lead."

159. Observations on Rotation Tests at Brandon."From observing the results obtained from these rotations and from farming conditions in Manitoba generally for a number of years, the following conclusions among others have been reached :-

1. A good mixed farming rotation not only provides for the future condition of the soil, but it gives a larger per cent. profit than straight grain growing.

2. Corn is an exceedingly valuable rotation erop, not only for its fodder value, but because the grain crops following it are the most profitable on the farm.

3. It is impossible to control soil blowing and wild oats by a straight grain and fallow system, no matter how well you eultivate. Grasses eontrol both satisfactorily.

4. The longer the start of mixed farming is postponed the more difficult it is to start.

5. The most profitable way to use grasses is in a short rotation. Left in sod too long they become umproduetive and hard to break up.

6. There is no best rotation for all farms. Each individual ease must be studied by itself and a rotation devised that will suit the kind of soil, the degree of weed infestation, the rainfall that may be expected, the convenience to market of the farm, and the plans, opportunities and limitations of the man who supplies the brains."

160. Mixed Farming Rotations at Lacombe.-The mixed farming rotations being eompared at the Lacombe Experimental Farm in central Alberta have been sum- 
marized by the ex-superintendent, Mr. Hutton, as follows:-

"Since corn is a praetical erop over a relatively small section of the West where mixed farming is most generally practised, and since the growing of roots on such a seale as would be necessary is prohibitive owing to the high eost of labor and the difficulty of housing, the rotation seheme has at onee been set aside by many farmers.

"The fact that within the last half dozen years the growing of oats alone or peas and oats sown together, for use as ensilage, has been sueeessful, puts an entirely dif- ferent light on this phase of agriculture. While the objection may be raised that the growing of green feed does not elean the land to the same extent as is done where eorn or roots are raised, yet the growing of green feed for ensilage does elean the land to some extent, since two or three erops of weeds may be destroyed before the erop for ensilage is sown. It is a thoroughly practical erop and provides ensilage that is at once highly palatable and nutritions. It readily forms a part of any rotation and is more economieally produeed than roots and much safer than eorn since there is no area where its culture ean be questioned because of unsuitability to elimatie conditions.

"Among the rotations which are at all suitable where mixed farming is practised are the following:-

$$
\text { "Rotation "L":- }
$$

1st year-Hay.

2nt year-Pasture. Manure 12 tons per aere.

3rd year-l'asture.

th year-Wheat. 
5th year-Oats.

6th year-Barley, seeded down to timothy, alsike and red clover.

Rotation "K":-

1st year-Hoed erop.

2nd year-Wheat.

3rd year-Barley, seeded down.

4th year-Hay. Manure 12 tons per aere.

5 th year-Pasture.

6th year-Pasture.

Rotation "O":-

1st year-Hoed erop.

2nd year-Wheat.

3rd year-Oats.

4th year-Summerfallow.

5th year-Barley, seeded down.

6th year-Hay.

7th year-Pasture.

161. Critieisms of these Rotations. - "The rotation first named, known as Rotation "L", has been modified slightly at the Lacombe Experimental Farm, and is now operated on a block of 240 acres and is known as the 'Main Farm Rotation'. The chief objeetion to the rotation as it is shown above will be pointed out when considering the modifications that have been introduced.

"In diseussing Rotation " $K$ " the objeetions already raised to the growing of hoed erops on a large seale obtain. Where corn is a doubtful erop, as it is over a very large proportion of the West, particularly those areas adapted to rnixed farming, no other loed crop is practical. No one would think of having a sixth of his furm in roots or hoed erops other than corn. 
"The objections to Rotation "O" lie in the fact that it requires one-severith of the land in hoed erop and also one-seventh in summerfallow. For areas such as this (central Alberta) . . . the summerfallow provides too mueh free fertility and stores suffieient moisture to produee a tremendous growth of straw, with the result that the erop invariably lodges, does not fill well and ripens irregularly. It is admitted that a better crop than barley eould be selected to follow the summerfallow, but no matter what cereal is sown the erop will lodge nine years out of ten.

162. A Rotation with many Advantages - "The lotation modifications as introduced in Rotation "L" are as follows :-

\section{1st year-Hay. Manure 12 tons per aere. \\ -nd year-Pasture.}

3rd year-Pasture. Plow six inches deep July or August, paek, cultivate and fall eultivate thoroughly.

the year-Oats, or oats and peas, for ensilage.

5th year-Oats.

6th year-Barley, seeded down, timothy and alsike clover.

"At the Latcombe Experimental Farm, as already stated, this rotation covers alout 240 aeres of land, and from the 40 acre field seeded to green feed we have this year filled one silo $12 \times 30$, one $16 \times 36$, and had sufficient crop on the field to have filled a third silo as large as the largest of those in nse. The dairy consumption per head for dairy cattle, where the silage constitutes the ehief part of the ration, rums only from 40 to 45 
pounds. Since from eight to ten tons are taken from each aere the stock-carrying capacity of the land is readily seen to be tremendously increased, as from two to two-and-a-half head of mature animals to the acre can be comfortably carried through the winter.

"This rotation has several distinct advantages, particularly for those areas where well-tilled summerfallows result in too great a growtl of straw the following year. The fall cultivation given the summer plowed sod is suffieient to produee a maximum erop without earrying so much fertility and moisture as to cause the crop to lodge seriously.

"The application of farm-yard manure at the rate of 12 tons per aere maintains soil fertility while the plowing under of the sod once in six years adds root fiber to the soil. One advantage in connection with the applieation of manure on the sod eonsists in the fact that during the rainy season weed seeds eontained in the manure germinate, but fail to develop for the reason that the manure soon dries out and the young plants are destroyed.

"There being but one year of the rotation in hay a maximum erop results; the application of the manure on the sod induces a free growth of grass for pasture, both the year the application is made and the one immediately following. . . . As has already been pointed out, the year following the breaking of the sod there has also been produced a maximum crop every year the rotation has been under way. If good cultivation is given land under this system the fifth and sixth years also produce satisfactory results."

163. Rotations with Sweet Clover. - I few farmers are testing a two-year rotation consisting of wheat seeded 
to sweet clover, the sweet elover to be pastured in fall and spring and then plowed under in June. They plan to reserve as much sweet elover for hay and pasture as may be neeessary. Some combination of erops including sweet elover offers mueh promise for the whole prairie area. If a strain of this crop, hardy enough to live through our winters after being sown with a nurse erop, ean be developed, a very promising rotation for much of the prairie area will be (1) fallow or hoed erop, (2) grain, (3) grain, (seeded with sweet elover or a grass mixture), and (4) sweet elover. Such a rotation might be shortened up to three years if thought advisable by omitting one of the grain erops. (See "Crop Rotations" in "Dry Farming Practices in South Dakota", ehapter xvi).

164. An Adjustable Rotation that may be made to meet almost every eondition of elimate and soil is as follows :-

\begin{tabular}{|c|c|c|c|}
\hline First $Y_{\text {EAR }}$ & Second Year & $T_{\text {inth }} Y_{\text {EAR }}$ & Fovetif Yean \\
\hline Fallow & Wheat & Wheat & Hay \\
\hline $\begin{array}{l}\text { or } \\
\text { Corn }\end{array}$ & Winter 1 & & \\
\hline or & or & & \\
\hline $\begin{array}{l}\text { nual Pasture } \\
\text { or }\end{array}$ & Flax & Rye, & Plowed under \\
\hline $\begin{array}{l}\text { or } \\
\text { xed Cer }\end{array}$ & Any $\stackrel{\text { or }}{\text { Suitable }}$ & $\begin{array}{l}\text { seeded down to } \\
\text { clover or grass }\end{array}$ & Some of each \\
\hline $\begin{array}{l}\text { and Peas } \\
\text { or } \\
\text { me of each }\end{array}$ & $G$ & & $\begin{array}{l}\text { Continue secon } \\
\text { year if neces } \\
\text { ary. }\end{array}$ \\
\hline
\end{tabular}

\section{Crop Rotations for Special Conditions. $-A$ crop} rotation planned to control annual weeds should have a grass erop. One to control soil drifting should have a grass erop or a crop such as winter rye or sweet clover that oecupies the land when blowing ordinarily oreurs. $A$ rotation in dry areas should include either a fallow or 
an intertilled crop, such as corn, at frequent intervals, while one in a short season in humid regions need have no fallow if mixed grass and legume crops are grown oceasionally and the sod plowed immediately after harvesting the hay.

The diffienlty in applying these practices to western eonditions lies in the delayed returns and relatively low yields from the erops classed as grass, legume or loed crops. In proportion as each is unprofitable in any community it will, of course, have to be omitted from the rotation, and some other measures taken for meeting the soil conditions the rotation is designed to correet.

166. The Effect of Rotations on Soil Fertility.-It is sometimes stated that a good crop rotation will maintain the fertility of the soil. This is quite erroneous. A good rotation will result in keeping up the productiveness of land mueh longer than continuous eropping either with or without fallowing, but it will maintain the plant food eontent of only one element, viz., nitrogen, and this only if legumes are grown frequently enough and a portion of the crop turned under occasionally. It is generally considered that the nitrogen can be maintained without fertilizer's if about onefourth of the land is kept in legume erops and a part of the crop or an oceasional eateh crop of some other legume plowed under and the erop residues returned to the land. The other important elements of plant food are, of course, used up faster in a rotation than in continuons cropping and eventually they will have to be kept up by using manure or commercial fertilizers or both. The value of a good erop rotation is not in its maintaining the plant food content of the soil (except nitrogen) but in its other benefieial effects. 'To per- 
manently maintain productiveness without live stock, not only is a good rotation necessary but also the use of eommercial fertilizers. In systems of live stoek farming when all the erop residues, such as straw and stubble and manure are returned to the land, soil produetiveness may be maintained for an indefinitely longer time than in systems of grain growing that do not include legume crops and commereial fertilizers. Yet even live stock farming is not a permanent system, exeept when butter and nothing else is sold from the farm.

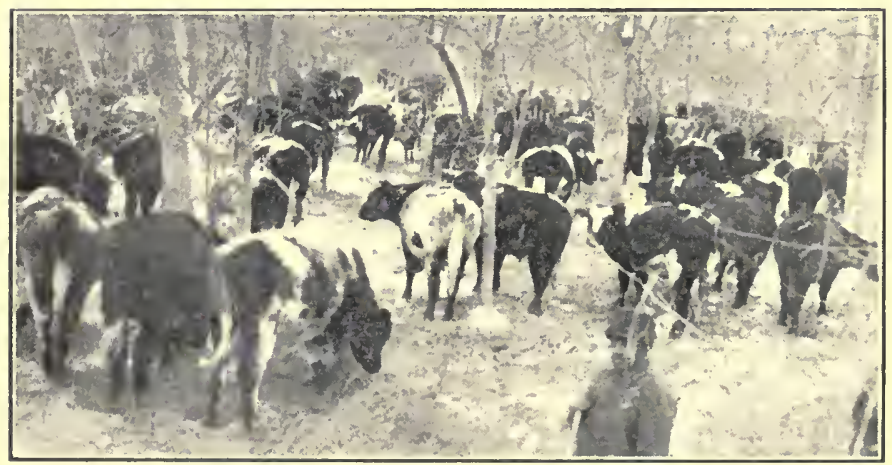

Fig. 75.-Cattle Wintering Outside, Protected only by the Trees. - Courtesy Man. Dept. of Agr.

Unfortunately the most permanent system is not always the best for immediate results. The farmer naturally and perhaps legitimately considers that system best which gives the most profit at the present time. The problem of the future lies in finding for each soil and climatic zone the system that is at once the most profitable and the most permanent.

\section{General Conclusions Regarding Rotations.-No} permanent profitable rotations have ret established themselves in this comntry. It is probable that in addition to the money erops ordinarily grown, the fallow, 
or a modification of it, will necessarily form a part of the rotations of the immediate future at least in the prairie area outside southern Manitoba; that coru, potatoes, roots or early plowed grass land may become partial substitutes for the fallow or an addition to the rotation in some areas; that alfalfa in the irrigated sections, sweet elover in the prairie area and possibly red clover in some favored humid regions will be the most satisfactory legumes; and that Western rye grass, brome grass and timothy will be the most suitable grasses. What the most profitable cash erops will be-whether wheat, oats, barley, rye, flax, potatoes, alfalfa or timothy depends chiefly upon the moisture and temperature and to some extent the soil and market conditions found in each climatic zone and on each type of soil.

$A$ rotation designed to store moisture should include a fallow or an intertilled erop, or in more moist parts, a hay crop ent early, the land to be plowed immediately; or it may include any two or all three of these.

If the ehief purpose of the rotation is to eontrol soil drifting it should include any one or any combination of the following, - a grass crop which protects the land and at the same time adds fiber to it, a cover crop, such as winter rye which only protects the land, or a crop such as sweet elover which protects the land and adds fiber and nitrogen to it.

The length of the rotation or the period between fallows or hoed erops will vary with the rainfall. In dry areas one or other of these means of stoling moisture in the soil will necessarily come at least every third year but in the more humid regions it need not be used so frequently. In the latter the fallow may eventually be partially or wholly replaced by hoed corops or the early breaking of grass land. 


\section{CHAP'TER XII.}

\section{WEEDS AND THEIR CONTROL}

Weeds are plants which interfere with the growth of erops or lower the profits of farming or mar the appearance of the landscape.

In a sense farming is a continual warfare against these intruders, the contending forces being man and erops on the one side and weeds on the other, with nature a neutral onlooker, but one ever ready to lend her aid to the side showing the greatest persistence. Most of our important farm crops have largely lost the power to compete with weeds. They have been so altered from their original wild state by man that were they left to themselves they would become extinet in a few years. Our eropping methods must therefore be intelligently directed if the fight for the profitable possession of the land is not to be lost.

There is no easy road to weed rontrol. Nevertheless a knowledge of the habits of wreds ancl the needs of cultivated crops placess a man in an enlightened position in the struggrle. It remains only for him to create conditions unfarorable to the one and favoralule to the other. Intelligent dirertion is much to be prefered over illplanned hard work. The chief diffirolty is encombered on old farens where the sins of the preeceding generation 
of farmers are being visited on the present occupants of the land. Under these eonditions it is generally a difficult problem to control weeds and at the same time make a profit from the farming operations.

\section{Why Weeds are Harmful.-}

(1) Weeds dissipate soil moisture (approximately $500 \mathrm{lbs}$. for every lb. of dry matter they produee).

(2) They use plant food that otherwise might go to the production of crops.

(3) They lower the yield of crops by crowding and shading.

(4) They lower the value of grain by eausing it to be "doeked" or to grade "rejected".

(5) They render seed unfit for sowing or eause extra expense in cleaning for seed purposes.

(6) They inerease the cost of tillage, twine, stooking, threshing and freight.

(7) They lower the value of the farm.

(8) Some weeds are poisonous.

169. Some Good Points About Weeds.-Yet weeds are not always harmful nor even useless. The weeds that grow on fallowed land pump tons of moisture from it, but when they are plowed under they add organie matter to the soil. This is seldom a sufficient exeuse for weeds in dry areas, even though the backward farmer may find some consolation in the fact. The moisture saved through the prevention of weeds growing on a fallow is generally of more value to the soil than the organie matter the weeds would produce. Nevertheless, the plowing under of weeds inereases the ultimate produeing power of the land, and on soils that need organic matter 
the practice is not an unmixed evil. Weeds also, under some conditions, reduce the loss of nitrates from the soil.

On some of our heavy soils in older districts where wheat lodges or ripens late, French weed or stinkweed is frequently very prevalent. No farmer there will say he prefers an infested to a clean farm, but many a wheat grower because of the fact that this weed in a fallow erop results in earlier maturity and in less lodging of the grain, eases his conscience by considering only its advantages. Such men are usually better philosophers than farmers. Yet there are many people who believe that the weed menaee is a blessing in disguise compelling as it does considerable tillage to keep it in eontrol. Whether one believes in this strange doetrine or not the bald facts remain that farms do become weedy, and that farmers must control weeds if they are to make a living.

170. Principles of Weed Control.-Weeds spread by means of seeds or by ereeping root stalks or by both, but in no other way. Weeds that spread by seeds can be controlled by preventing seed formation. Weeds that spread by ereeping root stalks can be controlled by (1) preventing seed formation, and (2) killing the plants already established in the soil. But a man gets reeds from outside his farm as well as from his own land. Hence, if his plans are to be efficient, he must also take steps to prevent the introduction of weeds to his fam from elsewhere.

The principles of weed control may then be stated simply as follows :-

1st. Prevent the weeds from dieveloping seedt.

2nd. Kill the perennial weeds. 
3rd. Prevent the introduction of weed seeds.

There are many different ways of putting these principles into practice but in the business of farming the cheapest and most efficient methods are the best.

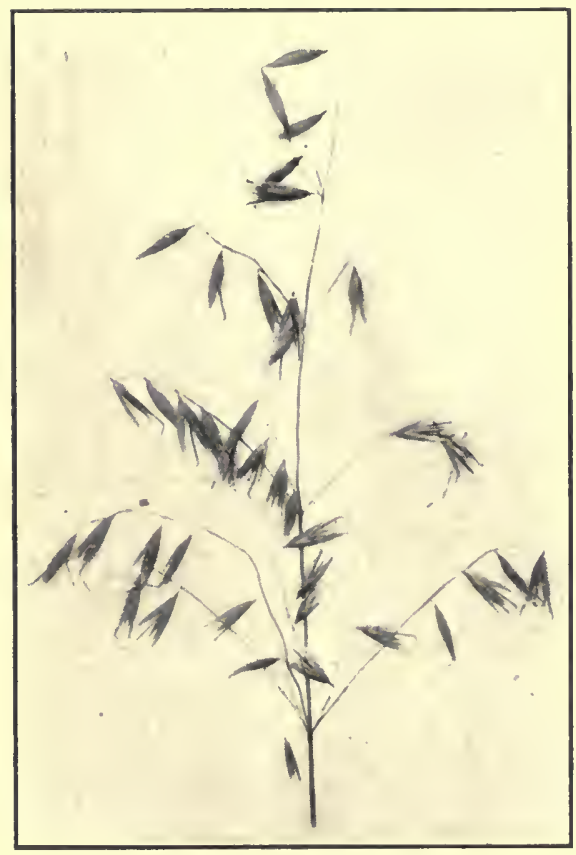

Fig. 76.-Wild Oats.

Ijnder different soil and elimatic rondfitions and with different weeds, different practices have naturally developed. The relative suitability of each method to any given farm or district must be determined by the man on the ground and his judgement will be more reliable if lue is informed on (1) the appearence of noxious weeds and their seeds, (2) the lhabits of girowth of the eommon weeds and how each spreads and (3) the most. suceessful methods of combating each tope of weed.

171. Identification of Weeds and Weed Seeds.-Space does not permit of including illustrations or even giving descriptions of the more important weeds and weed 
seeds of the West. Information coneerning the identifieation of these may, however, be found in one or more of the following bulletins:-

1. Farm Weeds - Clark, Dominion Department of Agriculture, Ottawa.

2. Better Farming - Bulletin No. 31, Saskatehewan Department of Agriculture, Regina.

3. Weeds of Alberta-Alberta Department of Agrieulture, Edmonton.

4. Plants Injurious to Stock-Bulletin No. 7, Department of Agriculture, Ottawa.

5. Weeds and Weed Seeds-Bulletin No. S. 8, Dominion Department of Agrieulture, Ottawa.

6. Weeds Used in Medicine-Farmer's' Bulletin No. 188, T.S.D.A., Washington.

7. Lessons on Weeds - Bulletin No. 30, Manitoba Agricultural College, Wimnipeg, Man.

172. Duration of the Growtl of Weeds.-The duration of growth of different classes of weeds varies comsiderably, some completing their life eycle in one season, some in two or parts of two, while others live three years or more. 'Thus we have ammal, biennial, wintel' ammal, and peremuial weeds, each type repuiriug a different treatment for its eontrol or eradieation. Anmuals die at the end of the first season's growth, winter ammals start in the late summer or early fall and die the next year, biemials die at the end of the sereond year, while peremials may live an indefinite number of years.

Ammuals, winter ammuals and biemnials an be completely controlled by preventing seed formation and the introduction-of weed seeds to the farm, but fo control peremials not only must seed formation and the intro- 
duction of seeds be prevented hut the plants alveady established must be killed. In the second columm of the tables in Sec. 174 the elassification of our worst weeds according to duration is indicated.

173. Habits of Root Growth and Time of Seeding.In addition to knowing the "duration of growth" of weeds, it is essential also to know the liabit of root growth of eaeh, beeause on this point depends very largely the nature of the means of eradication.

There are three more or less distinct forms of roots, (1) fibrous roots, (2) tap roots and (3) the. so-ealled "ereeping roots" or underground stems. Annual weeds usually have fibrous or tap roots, biennials generally have tap roots while perennial weeds may have fibrous, tap or ereeping roots. The following are typieal weeds of each of these types:

Fibrous rooted annual... Wild Oats.

Tap rooted annual...... Lamb's Quarter's and Most Mustards.

Tap rooted biennial..... Tansy Mustard and Blue Burr.

Fibrous rooted peremial. Wild Barley.

Tap rooted perennial.... Curled Dock.

Creeping rooted perennial.Canada Thistle, Sow Thistle, Quack Grass.

The creeping rooted perennials are the most diffieult to kill beeause of the fact that from each joint of the so-called "root" there may be sent up new plants even after 1 ils parent stem has been plowed down.

174. How Weeds Spread.-Nature is the ehief ageney in the spread of weeds but man is largely responsible for the present eondition of our eultivated fields. 
Among the influences by which man aids weed distribution are (1) importing weedy foodstuffs including hay, (2) sowing impure seed, (3) neglecting road allowanees and railway rights-of-way and freight yards, (4) using weed-infested, undecayed farm yard manure, (5) eustom threshing, and (6) by tillage machinery in moving from dirty roads or fields to clean fields.

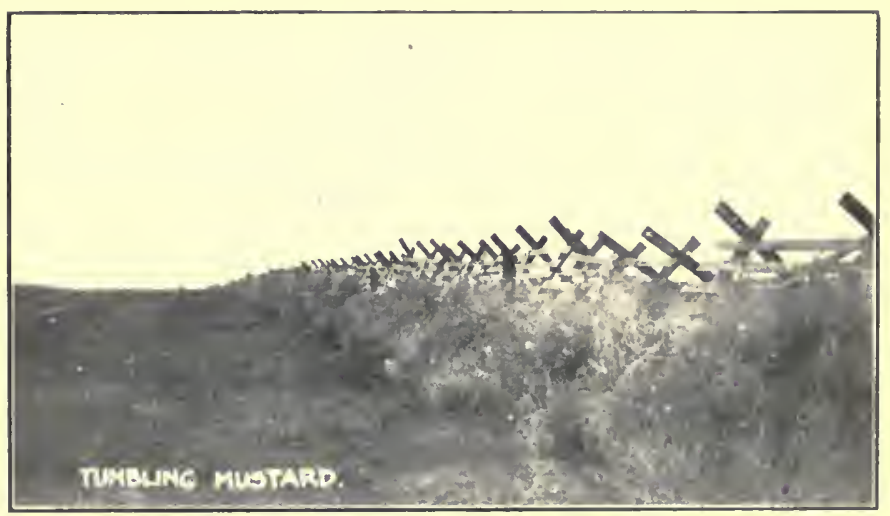

Fig. 77.-Tumbling Mustard Piling Up Against a Fence.

The Russian Thistle, another weed of tumbling habit is a serious menace to farmers in South Western Manitoba, South Western Saskatchewan and Southern Alberta.

The chief natural agencies resulting in the distribution of weeds are the wind, water, animals and birds. The wind seatters (a) fluffy or hairy seeds such as Dandelion, Canada thistle and Sow thistle, (b) winged seeds such as Dock and Parsnip, (e) seeds having extended edges such as Penny Cress, (d) plants that roll like Russian thistle and T'mulling mustard, (e) sticky seeds like Plantain adhering to weeds that blow, and (f) weed seeds in drifting soils. Trrigation water, flood streams, and rapid "run off" waten" also distribute 
many seeds. Barbed seeds such as Burdock and Blue Burr, attach themselves to animals and are thus distributed in the same way. In undecayed manure many undigested seeds are spread around and many small seeds are dispersed by dirt on the feet of birds.

The tables on the following pages give the duration of growth, time of ripening, brief note on the flower, and the method of spreading, of cach of our common wereds. 


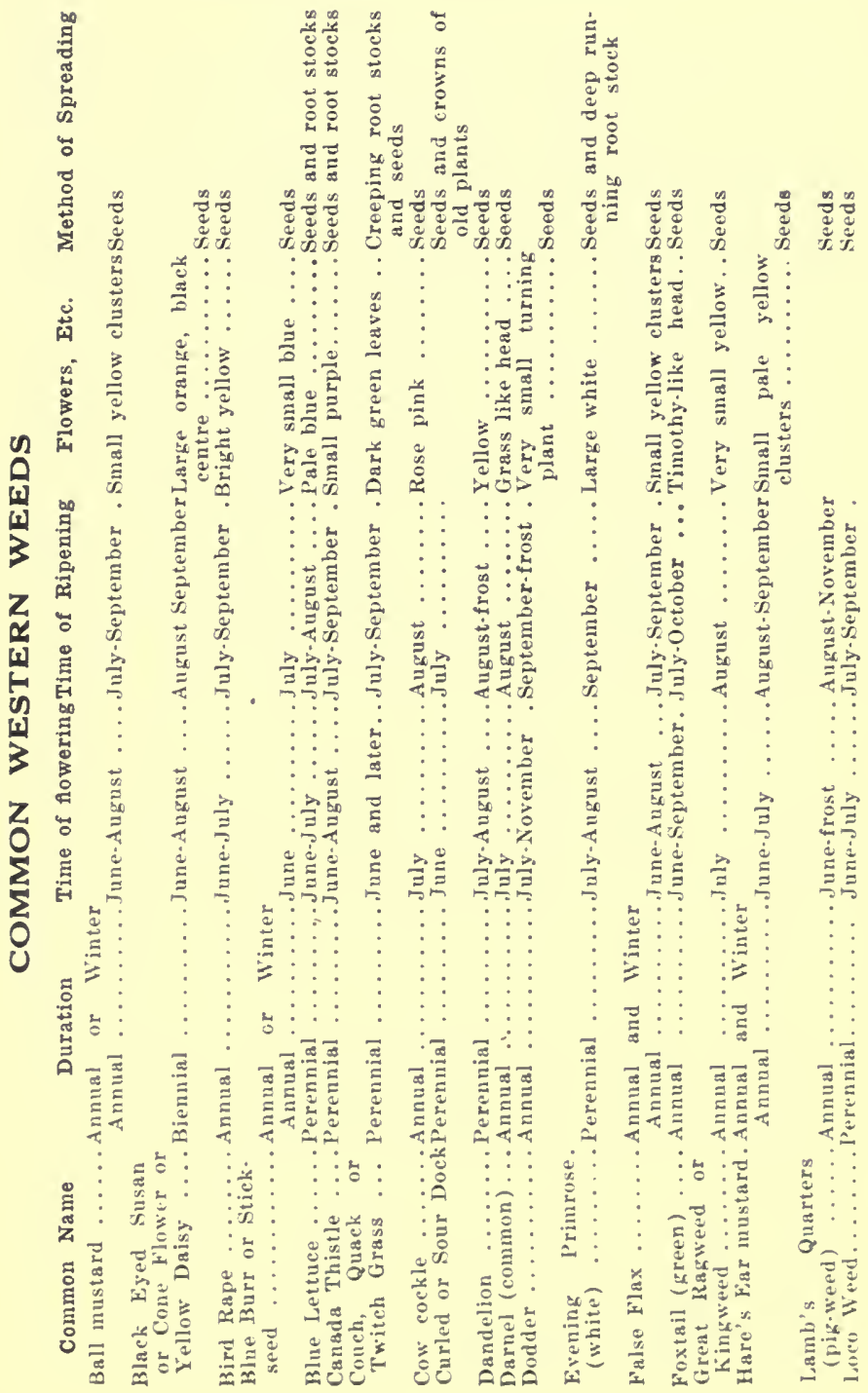




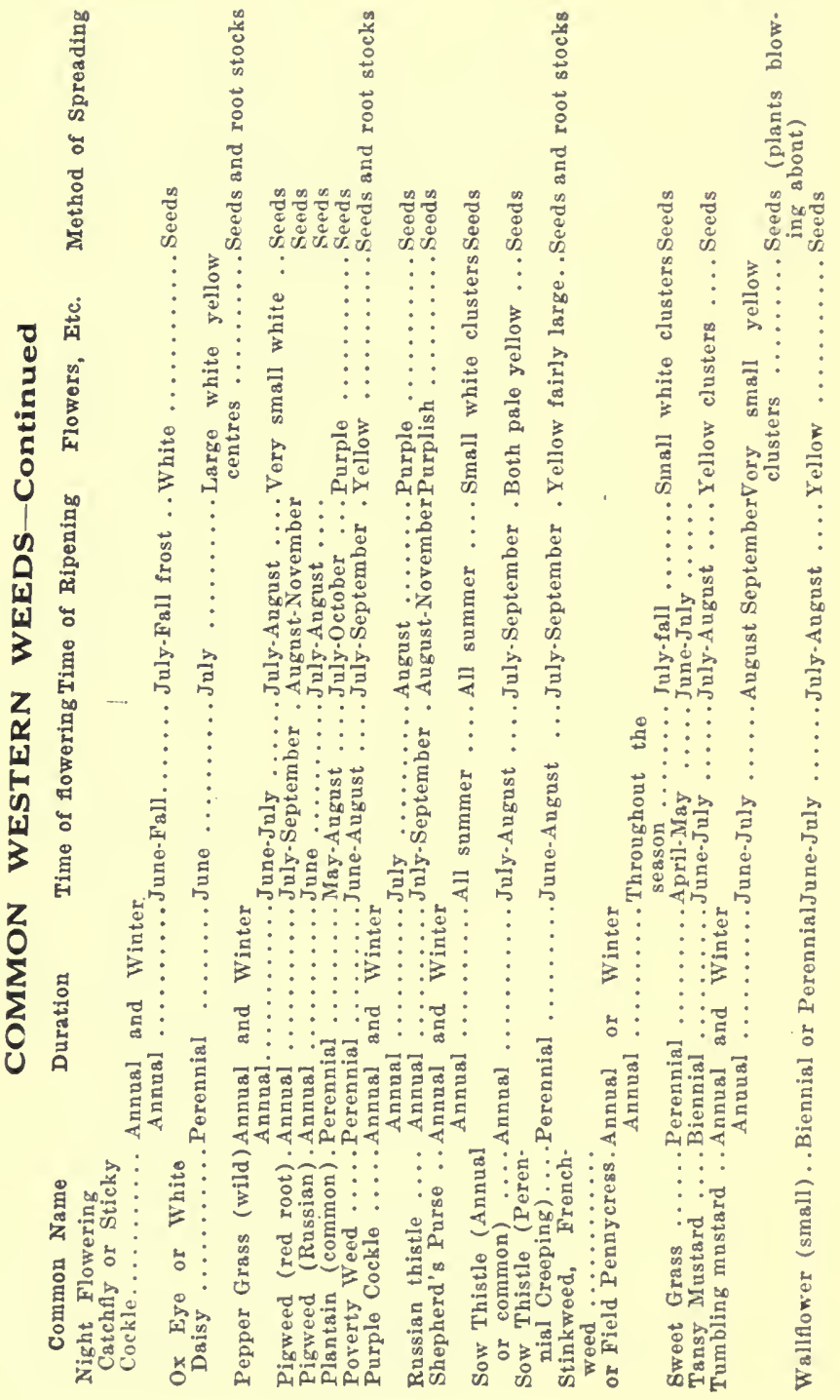



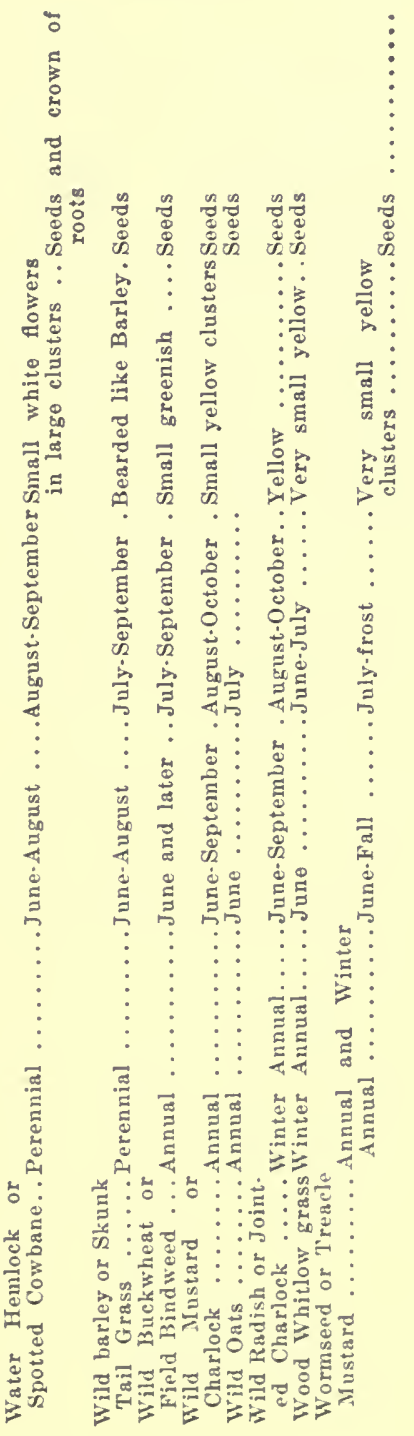
175. How to Prevent Weeds from Developing Seeds.A knowledge of the appearanee of the different weods, their duration, habits of growth and means of spreading, enables a man to outline intelligently the practices he should employ in controlling them, under the particular soil and elimatic conditions that exist where he lives. He will seldom use all of the means available to accomplish the end he desires but only such of the methods as best fit into his system of farming.

Among the chief means that are now followed on western farms for preventing weeds from developing seeds are:

1. Fallowing, to get the seeds in the soil germinated and the seedlings killed,

2. "Duckfooting" the fallow in late fall if biemnials are growing on it,

3. Late spring eultivation after weeds have started, and before early maturing erops are sown,

4. Sowing annual hay crops such as oats or beardless barley, to be eut before weed seeds mature.

5. Using early maturing grain crops such as Winter rye and Early Six barley, which ripen before many of the weed seeds,

6. Harrowing growing erops of grain after they are up to kill the small weeds that may be starting,

7. Early fall cultivation of stubble land to encourage germination of seeds, which may then be destroyed by the low temperature of winter,

8. Plowing stubble land in fall or spring if biennial weeds are prevalent,

9. Sowing perennial hay erops which (1) smother many weeds, and (2) are eut bofore most weed seeds mature, 
10. Mowing weeds on roads around fences and in waste places before seeds develop on them.

176. How to Kill Perennial Weeds.-Some of our perennial weeds are the most difficult of all to eontrol,

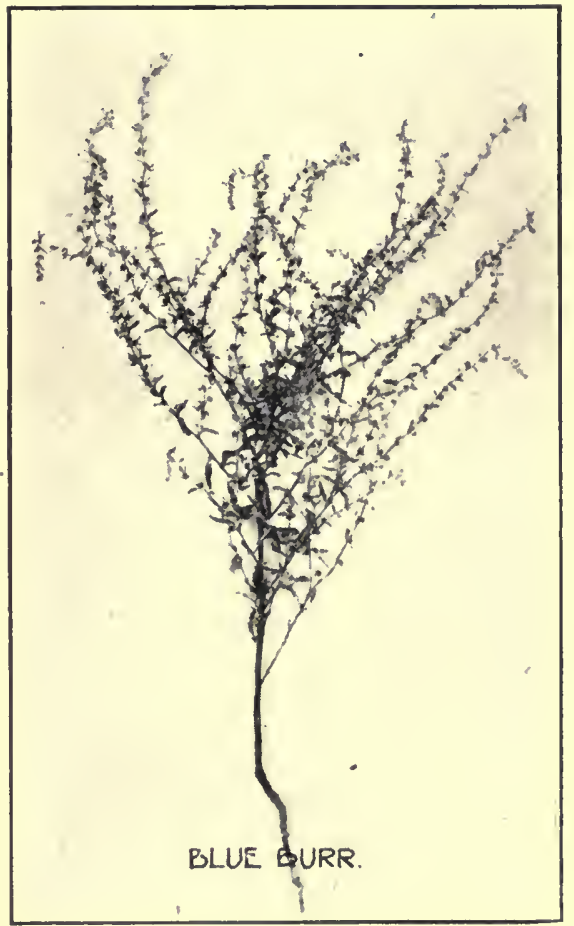

Fig. 78.-Blue Burr.

while some are quite easily eradicated. The tap or filorous rooted perennials cam be killed by deep plowing and careful covering of all vegetation, followed by surface cultivat ion. The creeping-rooted ones are not so easily dealt with. One plowing is seldom suffireirnt to kill them and fincyurntly several plowings do not suceeed in doing so. 'Three of the (ommont mothA typical tap-rooted winter annual or liennial. ods amployed in controlling the crecping-rooted perennials are as follow:-

1. Shallow plowing in the fall and dere plowing the noxt slmmmer after the weods have made a fresh start. The first plowing followed by the cold win- 
ter gives the plants a set-back and the deep plowing when they have not entirely recovered, gives them another. Surface eultivation as needed may then be given to prevent green leaves forming on any that may remain. This plan, or some modifieation of it, is generally used for the Perennial Sow Thistle.

2. Deep plowing as soon as the weather turns warm in May, then sowing thickly to a leafy erop like oats or barley. This often gives very satisfactory results with Quack Grass.

3. Mowing and removing the weeds just after blossoming when they are least able to stand a check, then deep plowing followed by deep, thorough and frequent eultivation to keep the land black. 'This is frequently used for the control of Canada Thistle.

177. How to Prevent the Introduction of Weeds to the Farm.-With the exception of a few native weeds all those now on our farms have grown from seeds that were introdneed to it by human or other agencies. The prevention of weeds eoming to the farm is the big problem of men on virgin soils, and not an unimportant problem for all other farmers. Among the means of prevention are:

1. Using only clean seed-unelean seed is chiefly responsible for the weed evil.

2. Buying only such feed grain as is free from Wild Oats, Mustard and other weed seeds, and such forage grasses as are free from Canada and Perennial Sow 'Thistles.

3. Controlling soil drifting. A man camnot, of course, farm his neighbor's land and he eamnot keep the 
weed seeds from blowing about. Co-operative community effort as well as better farming must be enlisted in the fight against weeds.

4. Cleaning the grain separator before if comes on the farm-the thresherman may resent this praetiee, but the farmer will suffer if it is not earried out.

5. Preventing stray animals roaming over the landthe dissemination of seeds in the mamure of wandering stock is of common oecurrence.

6. Preventing the roadside weeds going to seed-this may be the business of the community, but it is sure to be the individual farmer's loss if not looked after.

7. The intelligent enforcement of weed control legislation-laws do not kill weeds but they give power to communities to protect themselves from careless land owners and operators.

178. Means at Man's Disposal for Controlling Weeds.The chief means at our disposal for controlling weeds already in the soil are tillage, crop rotations, smothering, hand pulling, pasturing and the use of chemicals.

Tillage.-In so far as controlling weeds is a function of fallowing it is accomplished by tilling the latter in such a way as (1) to germinate the weed seeds present, (2) to kill the weeds that grow and (3) if not suceessful in the latter, to prevent the weeds forming seeds.

The use of hoed or intertilled crops enables one, at some expense, to germinate seeds and to kill many weeds without leaving the land idle.

By plowing in fall or spring every rear, hicmuials can be controlled absolutely and peremials can at least be kept in eheck. By disking early in the fall, annuats can 
be lessened but not entirely eontrolled. By using the duck-foot eultivator small weeds of all types rau be killed. By harrowing, young weeds ean often be lessened at a very low cost whetler they appear in the fallow or growing crop.

Digging by hand is not a popular method of reed control but when Canada or Sow Thistle are first observed in small patclies they should be "eradicated" by" hand if the area is too small to cultivate satisfactorily with machinery.

Crop Rotations.-If we had good crop rotations we could control our weeds at a small fraction of the present cost. In considering this question four important facts should be kept in mind:

1. Perennial hay crops will eontrol weeds having shortlived seeds, such as Wild Oats, providing the introduction of other Wild Oats seeds is prevented.

2. An occasional fallow encourages germination of weed seeds in the soil and permits killing the young plants shortly after they begin to grow.

3. Intertilled crops will lessen the necessity for fallowing to kill weeds but may not prove profitable on a large acreage under present economic conditions.

4. The use of early maturing erops that may be harvested before weeds ripen enables one to prevent seed development. Among these early erops are (1) grain erops to be cut for forage, (2) Winter rye and, (3) early barley.

Chemical Sprays. - A twenty per cent. solution of Iron Sulphate (100 pounds to 50 gallons of water per acre), applied on bright sumus days to mustard eoming into bloom, will prevent much of it developing. Another 
solution used is a two per cent. solution of Copper Sulphate (10 pounds to 50 gallons of water per aere). These ehemieals may be applied with either a hand or' power sprayer. Some men claim that Iron Sulphate solution will kill all Mustards, Cow Cockle, Dandelion, Canada Thistle, Bindweed, Plantain, Ragweed and some other weeds; other investigators are mucl less optimistic regarding the effieacy of chemical sprays. In any ease the practiee of spraying for weed control is expensive and has not yet therefore come into general use.

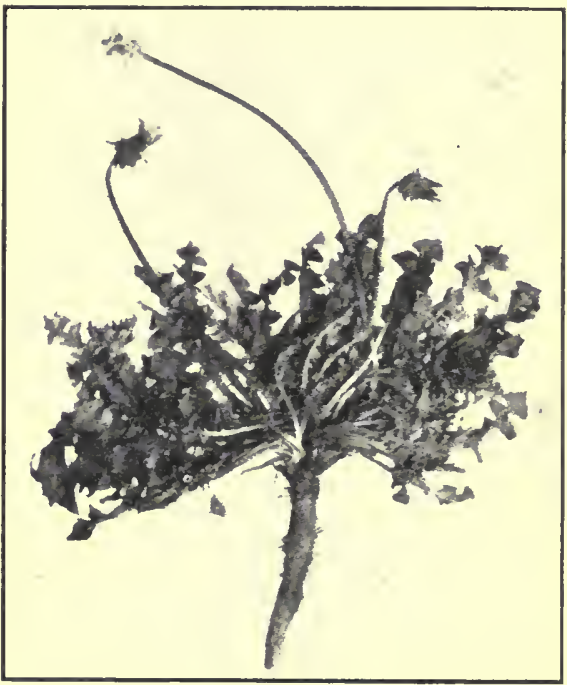

Fig. 79.-Dandelion.

A typical tap-rooted perennial. A bad weed in lawns and waste places in Manitoba.

\section{Pasturing. -}

When pasture is short, sheep aid in controlling Mustard, Plantain, 'Thistles, Lamb's Quarters, Shepherd's Purse and many other weeds but they seldom touch Stinkweed or Blue Burr.

Smothering.-Leafy crops on spring plowing aid in the eontrol of Quack Grass by smothering. It is a fact also that many young weed plants are prevented from developing by the crowding and shading of a good stand of any erop. This is why we find so many weeds where 
the drill has missed a strip and so few relatively where 110 skips in seeling occul. This fact is of great significance and should be appreciated by every grain grower. If we can suceed in giving our crops a good "start", particularly after having given the weeds a "set-back", our problem will have been made mueh "asiel; and a good even stand of grain with no skips or misses is important for the same reason.

Tar paper is sometimes used to smother Canada or Sow Thistle when found in small patches.

Hand Pulling.-Hand pulling weeds is expensive and with labor at present prices is impracticable except on small areas such as the seed plot, or as a preventive measure on relatively clean land. Where only a few weeds are present in a field "an ounce of prevention" is worth many pounds of "eure", and roguing a field may be much less expensive than leaving the weeds to multiply and to add to the difficulties of future crop production.

179. The Control of Annual Weeds.-The wild oat is a typical annual weed, and incidentally, one of the worst we have.

The first and most important measure of control is to stop sowing them, a measure that is easy to plan but difficult to put into practice.

The seeond is to prevent their introduction to the farm in feed, in threshing machines, by wandering stock, etc.

The third is to prevent them from going to seed by (a) double disking or plowing shallow early in the fall so as to eneourage germination and subsequent death by freezing, (b) killing as many as possible in the fallow year by disking after the first growth starts in the 
spring and plowing after the second growth starts, (c) growing a crop that may be harvested before the Wild Oats mature.

The above practices may be followed on any grain farm with no serious alteration of eropping plans and no lessening of the acreage sown. If the weeds are so

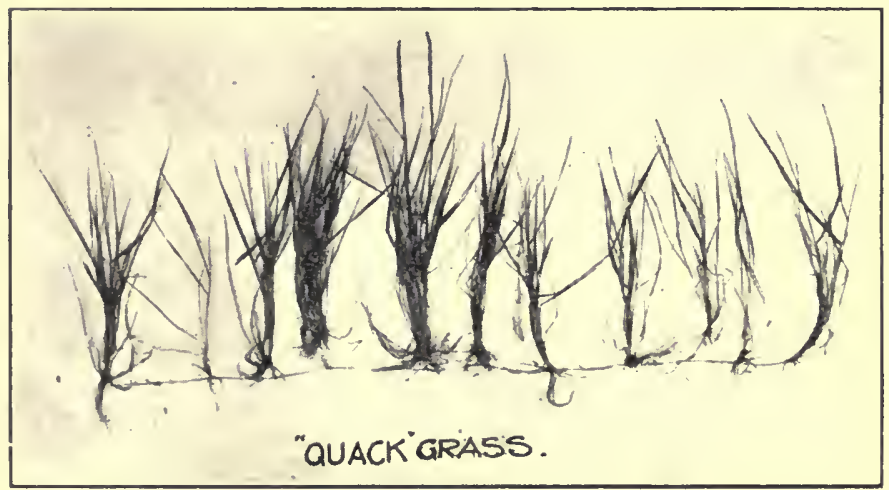

Fig. 80.-Quack Grass.

A creeping-rooted perennial that is difficult to eradicate.

prevalent that these measures are insufficient several others may be followed. Winter rye may be sown on the fallow to smother the oats the following year; or if the stand of rye is thinned out and wild oats grow, the erop may be eut for hay before the oats ripen. Early barley may be sown in the spring after a crop of wild oats has been killed by thorough disking or shallow plowing; and the barley may be cut for hay if the weeds develop, or left for grain if they do not. Early fall eultivation after this (rop, providing there is sufficient moisture, will start many of the oats still left in the soil. A corn crop or a potato crop may be used instead of the 
rye or barley and with better results. If these measures do not result in more or less complete cradication, tame grasses should be sown and left down two year's or more, and a year taken to break up the land before the next crop is put in.

The annual mustards and all other plants of similar habit may be eontrolled by the practices outlined for Wild Oats. Harrowing the growing crop after it is up, a practice tliat will not kill Wild Oats, is an additional means of killing the smaller seedlings of these annual plants. On aecount of the long time the hard seeds of many of these weeds may live in the soil, the use of perennial erops has not proven as useful a means of eontrol as in the ease of Wild Oats.

\section{The Control of Winter Annual and Biennial Weeds.} - Most of the so-ealled winter annuals, of which Tumbling Mustard and Stinkweed are typical examples, may develop as anmuals if they happen to get a start early enough in the season. If they start in the spring they may be prevented from seeding by the praetices suggested for eontrolling annual weeds. Those that start in the fall and those of the earlier plants that have not produeed seed may be killed by the treatment outlined in the next paragraph for biennials.

Blue Burr and Tansy Mustard are typical biennial weeds. If elean seed is always sown, and if seeds of Tansy Mustard are kept from blowing in, and those of Blue Burr from being earried in by stock or otherwise, these weeds ean be eontrolled by late fall or early spring eultivation of all fields whether fallow or stubble. Fall or spring plowing of stubble fields is to be preferred. Disking will kill the young plants only if the dises are sharp and the soil firm. Thorough eultivation of the 
fallow late in the fall with a "duckfoot" eultivator will kill most of the winter annual and biennial weeds that have started.

When dealing with either biennials or winter annuals it should be kept in mind, (1) that late fall eultivation

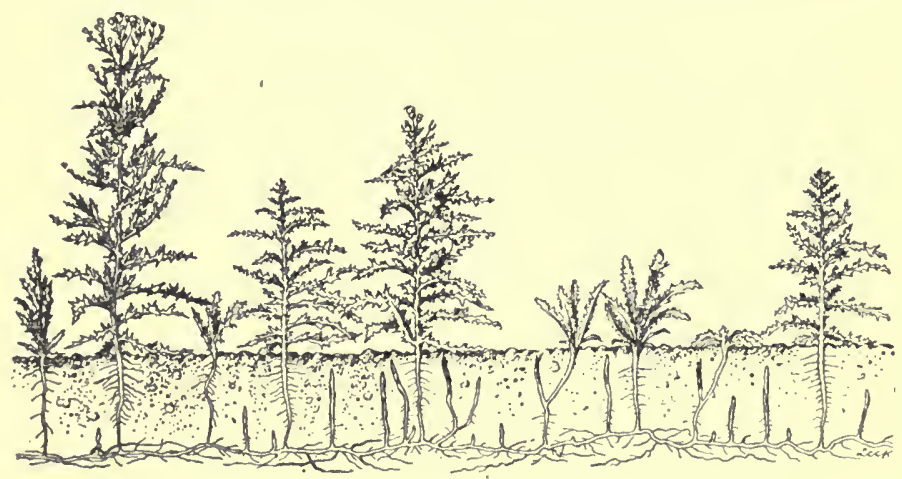

Fig. 81.-Canada Thistle.

A typical "cleeping-rooted" perennial. The Sow Thistle which is somewhat similar in habit is more difficult to control in the Red River Valley.

is essential whether early cultivation has been given or not, and (2) that the use of biennial crops like Winter rye and sweet clover which aid in the control of annual weeds, only foster the development and spread of biennial weeds.

In some seasons some biennial weeds will germinate, and like ammals, prodnce seed in the same year. Fall eultivation will not control these. The usual cultivation given to control other anmual weeds will, however, take eare of them.

181. The Control of Perennial Weeds.-The native quack grass (Agropyron glancum), is a trpical perennial weth in many parts of the West. It is less diffienlt 
to control than the eastem species (Agropyron repens). The chief methods of combating it in breaking are:-

1. Plowing all the land and leaving no skips or misses.

2. Plowing shallow early in June and plowing again deep late in the summer.

3. On less "grassy" land in more dry areas, and particularly in dry seasons, deep breaking followed by timely and suffieient surface cultivation may kill the native Quaek but seldom kills the Sweet grass so frequently found in low moist plaees.

The chief means of controlling Quack or other ereeping rooted grasses in stubble fields, are:-

1. Plowing in the fall-a "dry" time.

2. Plowing in spring and seeding, at once to a leafy erop such as oats or barley.

When present in the fallow, Quack grass may be controlled by,-

1. Plowing and digging out the roots with a spring tooth eultivator-always eostly and not always an effieient method, but sometimes advisable and neeessary.

2. Plowing twice, preferably shallow in the fall and deep in the late Jume or early July following.

Rose bushes ean be eontrolled in much the same ways but when baeksetting, or plowing stubble, or plowing fallow the seeond time, deeper work is neeessary and morc deep surfaee eultivation is desirable.

The Canada Thistle and Peremial Sow thistles in stubble are also very difficult to control. In addition to the praetices suggested above for Quack grass, frequent and thorough surface cultivation with eultivators having sharp cutting blades is desirable. After giving the plants as serious a set back as possible by deep plowing, 
one should endeavor to prevent the appearance of any young thistles above ground. This requires frequent thorough eultivation, but, given favorable weather, will result in the gradual death of the ereeping root stocks by starvation, because they eannot be nourished if green leaves are prevented from forming. A "green" fallow may be advisable oceasionally throughout the fallow year for eontrolling wild oats but a "black" fallow is essential for the eontrol of perennial weeds. If a field is infested with wild oats and perennial sow thistle the fallow should. be planned to kill the most prevalent weed since the two cannot be satisfactorily eradicated the same year.

182. Poisonous or Otherwise Injurious Weeds.-Poisonous weeds are seldom found growing on eultivated fields. They are usually found in native pastures or low uncultivated areas where tillage is never given. The most commonly found poisonous plants are Water Hemlock, Dwarf Larkspur, Tall Mountain Larkspur, Purple Larkspur, Small Larkspur, Woolly Loco Weed, White Loeo Weed, Poison Ivy, Lupines, Death Coma, Night Shade, Corn Cockle and Cow Cockle. The Crocus or Prairie Anemone is not poisonous but sometimes results in the death of sheep by the formation in the stomach of balls of the hairs that grow so profusely on the stems. Spear grass is sometimes injurious to sheep for a time when the "spears" are being shed, and to other animals when fed in hay, by the spears penetrating the flesh. 


\section{CHAPTER XIII}

\section{IRRIGATION FARMING IN WESTERN CANADA}

By W. H. Fairfield,

Superintendent, Experimental F'arm, Lethbridge, Alberta.

The applieation of water to the land by artificial means for the production of erops is a very ancient practice. Authentie reeords indicate that irrigation was used in Egypt over five thousand years ago, and in China and India at least as early. Even in North and South Ameriea remains of aneient irrigation ditches of great length have been found. "The development of irrigation from the time when man first watered lis erop with a bueket, then a doon, next a paddle wheel and finally the gravity system giving water to enormous areas, is one of the wonders and proofs of the advanee of eivilization."

It is estimated that at present nearly two hnundred million acres of land are irrigated, by far the larger part of which is in India, China and Japan, although large projects are found in United States, Egypt, Australia and Canada.

183. History of Irrigation in Western Canada.-In the early nineties, some years after completion of the main line of the Canadian Pacific Railway, preliminary sur- 
veys were inaugurated by the Govermment to determine the feasibility of diverting water from some of the mountain streams for irrigating a portion of the prairie land of southern Alberta. The first project of any magnitude was built by the Canadian North West Irrigation Company, now owned and operated by the Can-

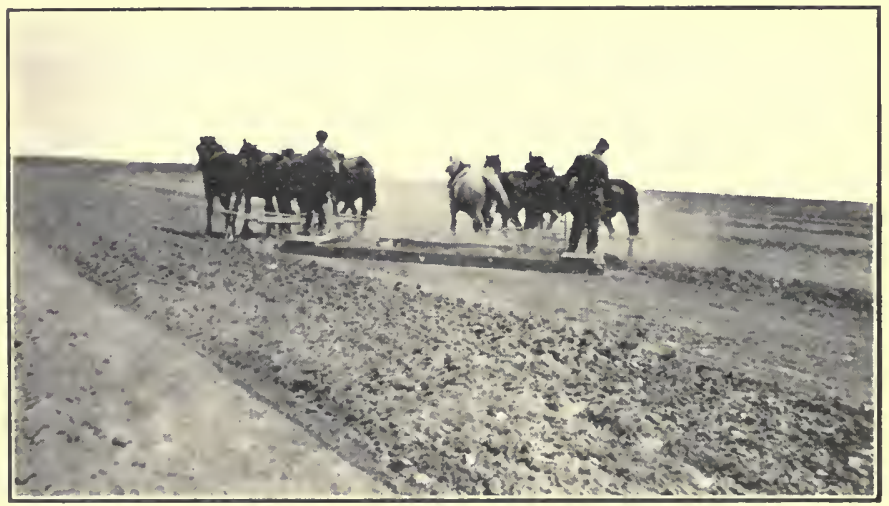

Fig. 82.-Float Levelling Land for the Border System of Irrigation.

adian Pacifie Railway Company, in the vicinity of Lethhridge where approximately 130,000 acres of land have been brought "under the ditch". Water was first earried by this ditch in the fall of 1900 . Five or six years later the Canadian Pacific Railway Company inaugurated an irrigation project east of Calgary, diverting water from the Bow River, to irrigate, approximately, 880,000 aeres in their block of $3,000,000$ acres of land extending from west of Strathmore to east of Brooks.

Previous to this time there were a number of small projects taken ont by private individuals, the greater number of these being in the sonthwestern part of Sas- 
katchewan, in the vicinity of the Cypress Hills, where the water is used almost exchusively for the irrigation of hay lands.

184. Methods of Irrigation.-There are various methods of applying water to the crops. The one best suited to a partieular loeality, or a partienlar crop, depends upon a number of factors. Among these might be mentioned (1) the nature of the surface of the land, whether it has a steep slope or is fairly level, (2) the eharacter of the soil, and (3) the kind of erop grown, ineluding the value of the erop, the latter determining how much expense might be warranted for the eonstruction of the system. Among the methods used are (1) Wild Flooding, (2) the Furrow System, (3) the Bedding System, (4) the "Cheek" System, (5) the Border Sy'stem, and (6) Sub-irrigation.

185. Wild Flooding.-This is the earliest and erudest system known. By it the water is diverted from rapidly flowing streams by plow furrows or small cheaply constructed ditelies and so spread over the bottom lands adjaeent to the stream, the idea being eithel to increase the yield of native hay or to insure a crop of small grains. The water is taken out of the ditches at convenient points and allowed to run practically at will until it reaches the lower ground, or possibly goes bark into the stream again.

186. The Furrow System.-This is used where the land has a steep slope, and often where the supply of water is limited. It is also employed in the irrigation of garden truck and all erops grown in rows. For the irrigation of grain crops with this system, shallow furrows thee or four feet apart are made on the land after the erop is sown but before it comes up. 'The water is allowed to 
triekle chown these furrows in such small amounts that washing of the soil does not take place and is allowed to run long enough so that the soil between the furrows is thoroughly wet. This method is not used on the prairies in Western Canada with grain or hay.

187. The Bedding System.-This is a method employed qn land whieh has little fall. The banks or dykes are

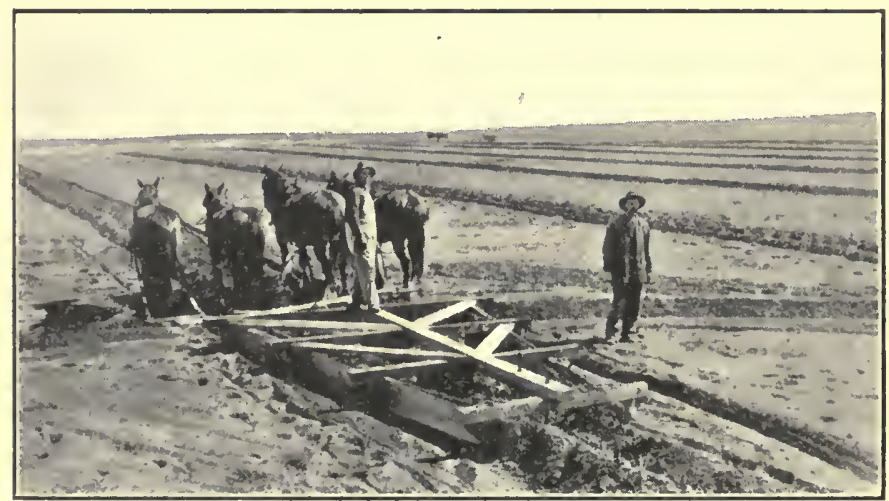

Fig. 83.-Making Borders for Border System of Irrigation.

raised so that the areas enclosed, from a fraction of an aere to an acre or more, are all covered with water. This is then drained into the next bed lower down.

188. The "Check" System is a form of bed irrigation and is used quite extensively on hay lands in the Cypress Hills district. The method followed is to dam the stream by building a dyke arross the valley. By this method the water, espeeially during the spring freshets, is ehecked and foreed back over the rreek bottoms. 'The' dykes are placed at different intervals, depending upon the fall of the strean, so that the bottom lanel may be completely submerged while there is sufficient water in 
the stream to allow this to be done. Proper sluice gates are, of course, installed in these dykes.

189. The Border System.-This is a modification of the flooding system and is very suceessful on hay and pastwre lands and will doubtless be used to a greater and greater extent on the prairie farms as development goes

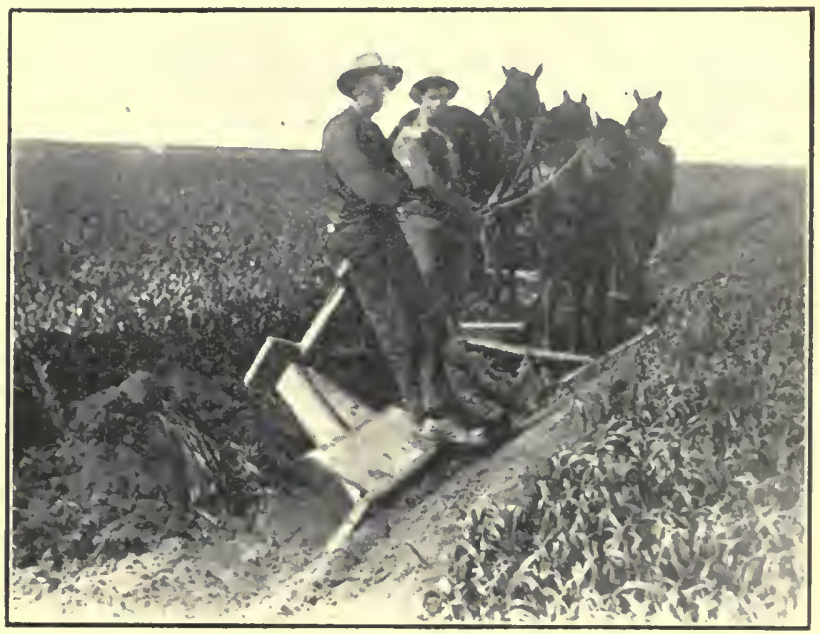

Fig. 84.-The " $V$ ", Ditcher at Work.

Making contour ditches for irrigating a grain field.

o11. The field (before seeding) is laid out in strips, two or three or four rods wide, up and down the slope of the land. Separating these strips, ridges six to eight inches high are thrown up. They are so arranged that where water is turned into one of these strips it will sprear out evenly between the ridges and irrigate the whole length of the strip uniformly with less labor than is usmally repuired with the ordinary flooding method. 'The entire field, ridges and all, are seeded. 
190. Sub-Irrigation, or upward irrigation is sometimes used where a very intensive scheme is inaugurated. This is done by the use of tiles laid in the ground just deep enough so that they will not be struck by the plow. These are kept full of water which percolates upwards and sideways from the openings at the ends of the tiles. This is not used on the prairies nor is it apt to be, for, although it has some advantages, the extremely high expense of installation makes it prohibitive.

\section{Relative Suitability of Various Crops under Irri-} gation.-Owing to the fact that our elimate is sub-humid or semi-arid rather than arid it is not necessary to irrigate all kinds of erops every season to obtain profitable returns. In this connection the hay erops are an exeeption since they rarely if ever produce abundantly in the dry parts without irrigation and they always respond favorably to the use of water. There is an old adage that eomes from northern Italy where irrigation has been praetised for several centuries, which says, "The more water the more hay". This is eertainly true in the drier parts of Western Canada with grasses and, with slight modifications, with alfalfa, potatoes and truck erops. Alfalfa is the most promising irrigation erop. Timothy also does exeeptionally well "below the diteh." The grain erops are somewhat less suited to irrigation in this elimate, but respond well to the timely applieation of water.

192. Irrigating Timothy and Native Grasses.-The management of these erops is perhaps less difficult than that of any other's now grown under irrigation in Western Canada. The proftt depends solely upon an adequate supply of water evenly applied to the fields from the time growth starts in the spring, which is early in May, 
up to the latter part of June. The amount of water that may be applied to grasses is greater than for any other crops that aire raised. The land selected for the growing of such hay should be reasonably level and should not have too great a slope. In other words, conditions must be such that water can be easily and often

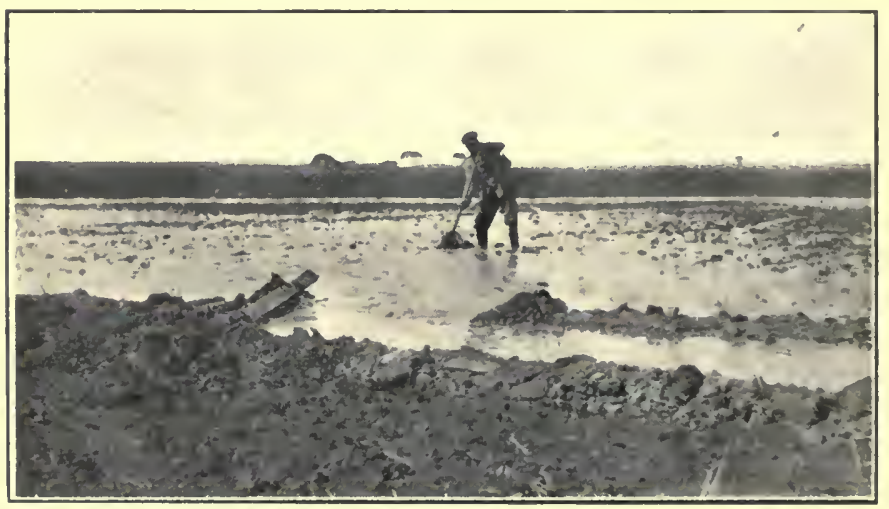

Fig. 85.-Irrigator at Work.

applied and at not too great expense for labor. It is necessary if the best results are to be obtained that the surface of the soil should never be allowed to dry out. With the grasses a cool, moist condition at the surface is essential for maximum returns. It is also important that the field be given a thorongh soaking in the fall so that the grass may grow vigorously in the spring even before the irrigation water is applied.

In the preparation of land for timothy some excellent results have been obtained in eertain localities where the native sod has not been broken but the surface disked and the seed sown. The seed usually germinates on the 
application of water and the young plants grow vigorously if the surface of the soil is kept moist. The resulting hay is a mixture of native grass (principally Blue Joint) and timothy which makes an excellent forage, more nutritious and more palatable to stock than timothy alone.

193. Alfalfa under Irrigation.-Among all crops that are now raised under irrigation in the West none is so well adapted to this type of farming as alfalfa. The preparation of the land for this crop should be the same as when it is raised under dry land eonditions exeept that a greater amount of seed should be used. From fifteen to eighteen pounds of seed is generally recommended. The thicker the stand obtained the greater the yield and the finer and better the quality of the hay will be. In all eases seed grown in Western Canada is to be preferred. In loealities where winter killing is common only extremely hardy strains such as Grimm or Baltie should be used.

The irrigation of alfalfa is somewhat different from that of the grasses in that the field should be irrigated and thoroughly soaked as rapidly as possible and then the surface allowed to dry so that the soil can warm up. In the Lethbridge distriet, where the largest aereage of alfalfa in the West is now grown, it is not always neeessary to irrigate for the first cutting but it is usually adrisable. The eommon practice is to take two euttings but three euttings may be obtained in ordinary seasons by taking the first entting about the 1.5th or 20th of June instead of from one to two weeks later. As soon as each erop is removed from the land the ficld should be immediately irrigated, i.e., there should be an irrigation for each cutting. Fall irrigation for alfalfa has been 
found as a rule to be a good practice, although in a few places where the land is extremely heary late fall irrigation is of somewhat choulteul value.

194. Grain Crops.-There has been some contention as to the advisability of irrigating growing grain in certain localities where the season is short, and the grain slow in

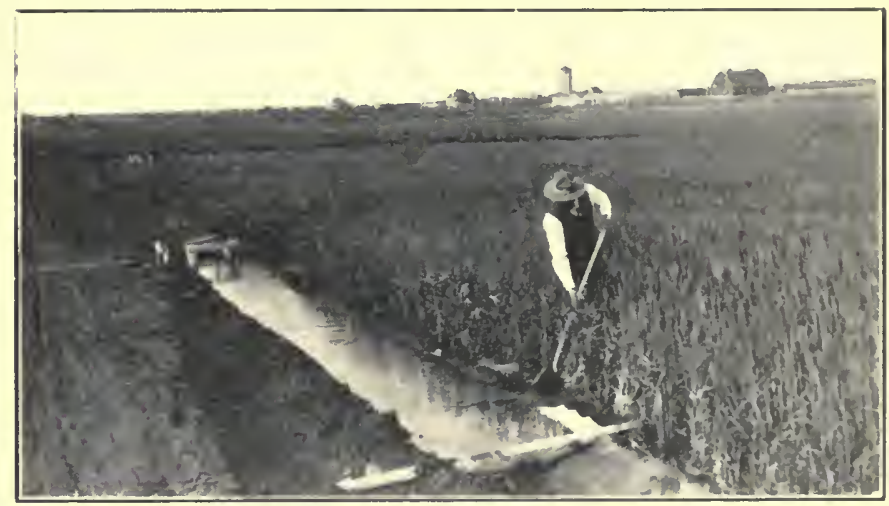

Fig. 86.-Irrigating Wheat, Strathmore, Alta.

ripening, on arcount of danger from frost in the fall. In such localities this diffieulty can be overome hy irrigating the land in the fall after the growing soason is over. 'This is a commendable practice under all ciremmstances. But in dry seasons event when the land has been irrigated the fall previous, the growing crop must be irrigated again if maximum vields are to be ohtained. In most distriets where irrigation is now practised growing grain ean be irrigated quite safely, and certainly actvantageously, providing the water is applied before the (erol) has suffered materially from drought. The secret of raising grain successfully under irrigation is preparedness. The period in which water ean be applied to 
a particular kind of grain to obtain the best results is limited to less than three weeks, consequently a man with a large aereage of grain must have his ditehes made, and be prepared to apply the water expeditiously, as soon as the time arrives when he thinks it is wise to apply it. It is better not to put water on a grain erop till the stooling process has been eompleted, otherwise the application of water might affeet the development of the crop at this point. As a rule one irrigation is all that is required, but in extremely dry seasons a seeond irrigation is necessary, if the best results are to be obtained. The method used is to flood irrigate from laterals put in at from forty to seventy yards, apart in the field. These may be run lengthwise of the ridges or "hogbacks", or contour ditches may be put in at right angles to the fall of the land. The latter plan is usually preferable. It is better to have the ditehes too close together than too far apart.

195. Potatoes.-It requires more skill and experience to raise potatoes successfully under irrigation than any other crop commonly grown. The secret appears to lic in being able to keep the plants growing vigorously from the beginning with no setbacks, and on the other land in being able to apply the water so that too sudden growth will not be stimulated at any time. The first irrigation should be very light, and it should not be given until the small potatoes are set and perhaps the size of peas. This stage is usually about the time the first blossoms appear. If the erop is wet before this time there is danger of the plants setting more potatoes than they will be able to develop to a marketable size. To be sure that the potatoes are not wet too much when the first irrigation is given, it is well to run the water between 
every alternate row only, and turn it off just as soon as it gets through so as not to let the ground soak up any more than is neeessary. As soon as the ground dries suffieiently the land should be given a shallow cultivation.

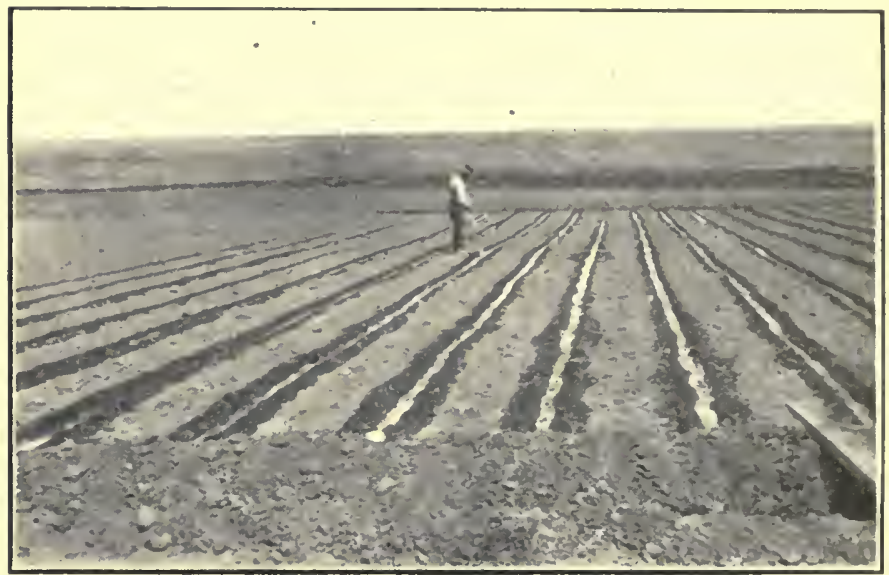

Fig. 87.-Furrow System of Irrigation.

About ten days after the first irrigation, the second should be given. This time the water may be run down between all the rows and should be allowed to remain running until the land is well wetted. After irrigation has onee begum, the land should never be allowed to dry up eompletely. Unless heavy showers intervene, it will be found neeessary to irrigate about every ten days in order to maintain a moist condition. After each irrigation as soon as the surface of the soil dries sufficiently it should be given a shallow eultivation. If for any reason after irrigation has once begun the land is permitted to become quite dry the potatoes should not be irrigated again. If they are, a seeond growth is almost eertain to 
be indueed, and this will injure the quality. The main eause of soggy potatoes, when grown under irrigation, is allowing the land to beeome somewhat.dry so that the growth is checked, and then applying water and indueing a fresh growth of roots and tops.

196. 0ther Crops, Including Trees.-All garden truek, should be furrow irrigated with sufficient cultivation between irrigations to prevent the soil from crusting.

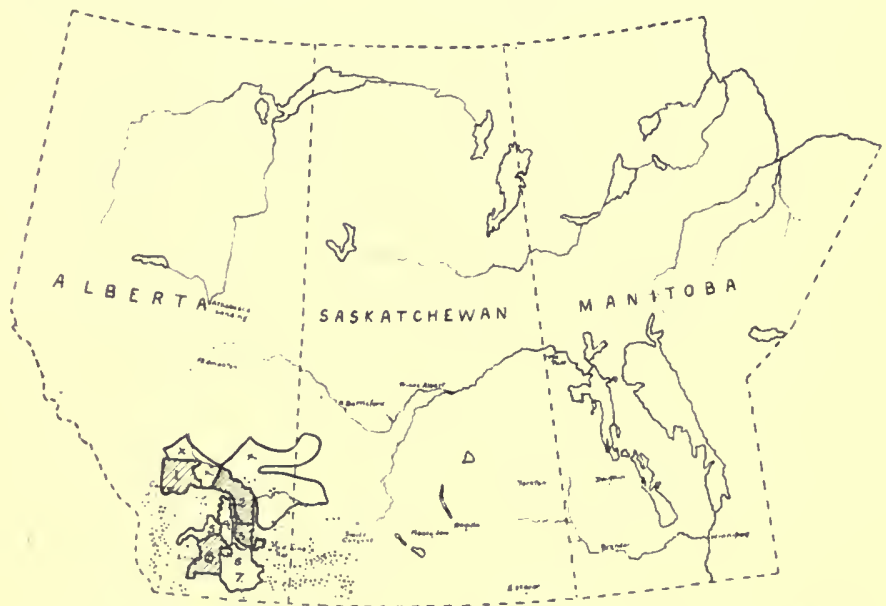

Fig. 88. - Map Showing Location of Irrigation Projects Under Way or Projected.

The dots indicate the number and location of small private irrigution schemes.

Strawberries and small fruits such as eurrants and raspberries should be irrigated often during fruiting time to keep them growing in a vigorous manner during the time the fruit is forming and ripening. With trees and shrubs generally the water should be applied liberally in the early part of the spring but should eease during the latter part of July and August so that the land may 
have a chance to dry out and so induce the new succulent growth to harden up properly for the winter. This is an important point and one that is often overlooked. Trees that are ordinarily perfectly hardy are made tender and suffer from winter killing owing to the fact that rapid growth is maintained right up to the time hard frosts may be expected. After the leaves start to drop in the fall it is well to give the trees and shrubs a liberal soaking. 


\section{CHAPTER XIV}

\section{THE CAUSES AND CONTROL OF LOW YIELDS}

197. The Causes of Low Yields.-The major causes of low yields in the West at the present time are climaticdrought, frost and high winds. The many minor eauses are the cropping and soil management practices man employs or fails to employ-in the operation of his farm.

In the final analysis all low yields trace back to one or more of six fundamental things:-

1. The purity or quality of the seed.

2. The suitability of the erop or the variety.

3. The supply and availability of the plant food in the soil.

4. The moisture in the soil.

5. The temperature of the soil and air.

6. The amount of air in the soil.

But while this list inchules the immediate or fundamental canses of low violds, yet each of these is the direct result of certain other influences or practioes to which is generally aseribed the canse of the decreased return. The former may be regarded as the immediate or fundamental eanses, the latter as the practical causes of partial or complete failure.

The fundumental cause of low yield in a certain field may be lack of moisture. The pratical canse may have been poor fallowing, weeds, warm winds, low precipita- 
tion or any of the eauses that go to diminish the moisture content of the soil. The fundamental cause of low yield in another field may be insufficient available plant food. The praetical eause may have been an infertile soil, unsuitable tillage, continuous cropping with no return of plant food or any of the other causes that deerease or leave undeveloped the plant food in the soil.

In this ehapter we shall diseuss the practical eauses of low yields because it is with these the grain grower is most familiar and it is these he usually advanees to explain why his erops are not satisfactory. Among these are:-

198. Poor Seed.-Poor seed is seed that will either not germinate or will not grow vigorously, that eontains dis ease or impurities or that belongs to a variety that is not suited to the distriet where it is to be grown. 'The vigor of growth and pereentage of germination ean be determined by making a germination test. Its freedom from impurities including most forms of disease can be told by examining the seed or by its odor, but the presenee of some diseases ean only be deteeted in the field before the crop is harvested. The suitability of the variety to a district eannot be foretold by examining the seed. This point can only be determined from the experience of other farmers or from carefully condueted tests.

The seed may be so inferior that it will produce no erop, it may be so good that it will result in maximum returns or it may oeeupy any intermediate stage of perfeetion. No intelligent farmer takes ehanees on his seed being the cause of decreased yield. This is one of the factors of production that lies wholly within the power of the farmer to control.

199. Too Early or Too Late Seeding.-The best time to 


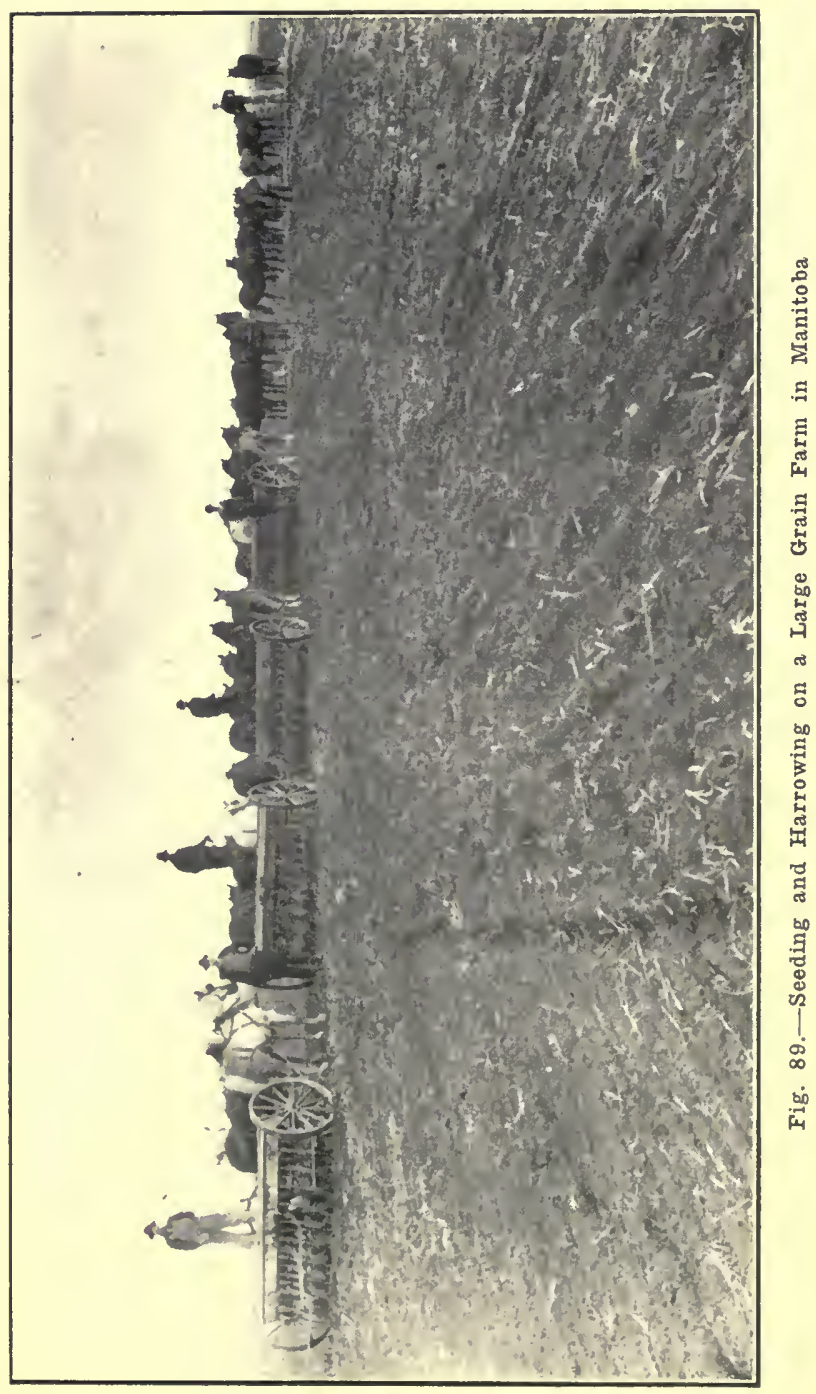


sow is determined latrely by the temperature conditions of spring and fall. Whes sown too early the seed may rot or the early growth freeze. If sown too late the crop may be injured by frost in the fall. Our grain erops are quite resistant to spring frosts but very susceptible to fall frosts. Corn and potatoes are very suseeptible to spring frosts and suffer from the first fall frosts while roots and rape will stand very heavy fall frosts. The peremial grasses and alfalfa withstand both spring and fall frosts of eonsiderable severity. As a rule all spring sown erops should be planted between April 10 and the end of Jume in the following order:-wheat, rye, peas, oats, barley, flax, roots, potatoes, sunflowers, eorn and alfalfa. If no nurse crop is used grasses and clovers should be sown in . June, otherwise they may be put in with spring sown nurse crops at an earlier date.

200. Too Much or Too Little Seed per Acre.-The amount of grain to sow per aere is greatly inflneneed by the moisture and temperature eonditions prevailing. A thin stand is desirable in dry areas having a medium to long growing season while a thick stand is preferable in humid regions, particularly where the growing season is short. It is hardly eorreet to say that thin seeding is always desirable in dry areas and thick seeding in Inmid areas for the reason that the eondition of the soil with respect to moisture and tilth at seeding time largely determines the stand. Thin seeding on a perfect seed bed may give a grood stand, while thick seeding on poorly prepared land may result in a thin stand. 1t should always be our aim to have a good seed bed and then sow thinly in dry areas and on diry soils and proportionately heavier in more moist regions and those having a shorter growing season. A thin stand will withstand dronght 
better than a thick stand but a thick stand will ripen earlier than a thin stand.

201. Unsuitable Varieties. - Varieties of any of our common grain crops that from any eause, such as lateness, low quality, weak straw, or susceptibility to frost or disease, are not well suited to our conditions, result either in low yichls or in decreased prices. The standard varieties that are known to be suitable to the different parts of the West are as follows :-

\begin{tabular}{|c|c|c|}
\hline Crop. & $\begin{array}{c}\text { Best Varieties at } \\
\text { Present. }\end{array}$ & Promising Varieties. \\
\hline Wheat & Marquis and Red Fife & $\begin{array}{l}\text { Kitchener for yield } \\
\text { Red Bobs and Ruby } \\
\text { for earliness }\end{array}$ \\
\hline Oats & $\begin{array}{l}\text { Bamner, Victory and } \\
\text { Gold Rain }\end{array}$ & \\
\hline Barley & $\begin{array}{l}\text { Manchurian and O.A.C. } \\
\text { No. } 21\end{array}$ & $\begin{array}{l}\text { Hannchen for grain } \\
\text { Early Six for earli- } \\
\text { ness }\end{array}$ \\
\hline Rye-Wintrer & $\begin{array}{l}\text { N. 1). No. } 959 \text { and Sas- } \\
\text { kitchewan }\end{array}$ & \\
\hline $\begin{array}{l}\text { Rye-Spring } \\
\text { Flax }\end{array}$ & $\begin{array}{l}\text { Ottawa Select } \\
\text { f'remost }\end{array}$ & Prolifie \\
\hline Pris & Arthur & $\begin{array}{l}\text { Early White, Al- } \\
\text { berti Blue and } \\
\text { Carleton }\end{array}$ \\
\hline Roots-Swodes & Bangholm and others & \\
\hline 'Turnips & Green Globe and others & \\
\hline $\begin{array}{l}\text { Mingels } \\
\text { lverage: Soils }\end{array}$ & $\begin{array}{l}\text { Yellow Intermediate and } \\
\text { Globe troes }\end{array}$ & \\
\hline Decep Soil & $\begin{array}{l}\text { Long Red and White } \\
\text { Sugar }\end{array}$ & \\
\hline Slallow Soils & Gulden Tankard & \\
\hline Carrots & $\begin{array}{l}\text { Varioties of White In- } \\
\text { termediate Type }\end{array}$ & \\
\hline l'otatoes & & \\
\hline Early & $\begin{array}{l}\text { Finly Six Weoks, Early } \\
\text { Ohio }\end{array}$ & \\
\hline Medium & $\begin{array}{l}\text { Irish Cobbler, Rowhester } \\
\text { Rose }\end{array}$ & - \\
\hline
\end{tabular}




\begin{tabular}{|c|c|c|}
\hline \multirow{2}{*}{\multicolumn{2}{|c|}{$\begin{array}{c}\text { Crop. } \\
\text { Potatoes (cc }\end{array}$}} & \multirow{2}{*}{ Promising Varieties. } \\
\hline & & \\
\hline Late & $\begin{array}{l}\text { Wee MeGregor, Car- } \\
\text { men No. 1, Gold Coin } \\
\text { and others }\end{array}$ & \\
\hline Corn & & \\
\hline $\begin{array}{l}\text { Early } \\
\text { Late }\end{array}$ & $\begin{array}{l}\text { Squaw, Patterson, Gehu } \\
\text { North Dakota White, }\end{array}$ & Quebec No. 28. \\
\hline Grasses & $\begin{array}{l}\text { Longfellow, North West- } \\
\text { ern Dent } \\
\text { Western Rye Grass and } \\
\text { Brome Grass; Timothy } \\
\text { for more humid parts. }\end{array}$ & \\
\hline $\begin{array}{l}\text { Clovers } \\
\text { Sweet Clover } \\
\text { Alfalfa }\end{array}$ & Grimm & $\begin{array}{l}\text { New hardy strains } \\
\text { New hardy strains } \\
\text { Baltic and new } \\
\text { strains of Grimm }\end{array}$ \\
\hline
\end{tabular}

New varieties are appearing from time to time and while the great majority of these are not equal to the elaims made for them a few are quite sure to be superior to the old sorts. Nevertheless new settlers and inexperieneed Westerners should use only standard varieties. It is of course desirable that the testing of new varieties be encouraged on all different soil types and in all climatic zones of the eountry for the reason that the Experiment Stations are so few and so far apart that their conclusions regarding the suitability of varieties are not neeessarily applieable to all parts. At the same time a large aereage of a new sort should never be sown until it has given positive evidence that it is as good or better than the standard ones used.

202. Shattering.-After a grain or seed erop has started to mature a considerable loss often oecurs as a result of shattering due either to winds or to the necessary handling at harvest time. This loss is greater in some elasses of erops than in others and in some varieties 


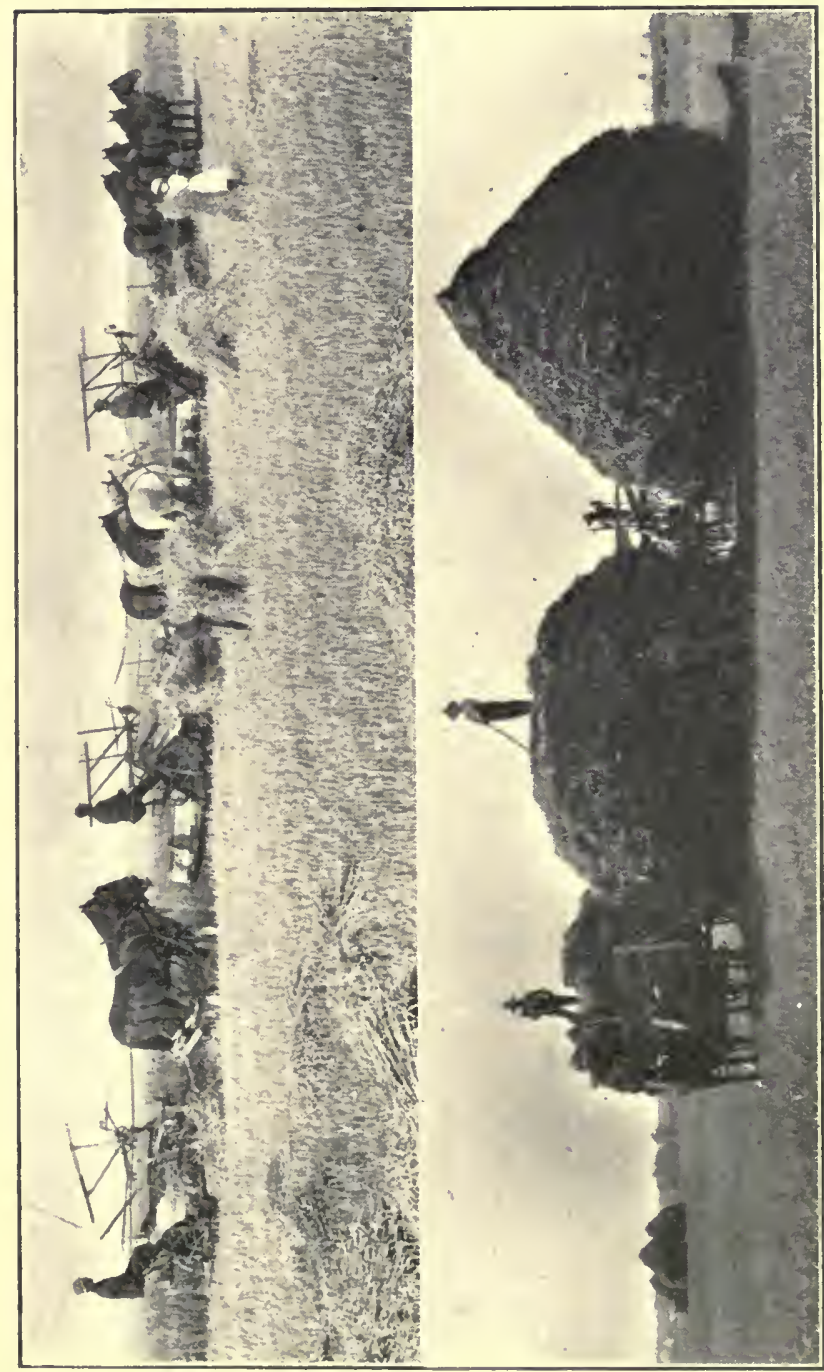

告) 
than in others. It is greatest in over-ripe crops and least in inmature ones. 'The D) Drum or Macaroni wheats are our most non-shattering varieties. Marquis shatters less than any of our other eommonly-grown sorts. Barley does not shatter seriously, but the heads break off easily after maturing. Rye shatter's very easily if let got too ripe. The seed of the grasses and sweet clover when allowed to mature also shatters freely. Early harvesting, eareful handling, and the use of non-shattering classes or varieties, are about the only practices that will offset this possible loss.

203. Late Breaking.-The results of experiments at Saskatoon during the last four year's indieate that delay in breaking native prairie after the tenth of .June deereases the yield of wheat one bushel pere acre per week, or what is more important, decreases the profit from $\$ 8.44$ per aere on Jume 10th breaking to $\$ 3.81 \mathrm{om}$ August breaking and $\$ 1.09$ on breaking done in the month of September. It is impossible on a farm to do every job at the best time, but when the best time is known a man ean so shape his plans that as much as possible of the work ean be done when it slrould be done.

These conchusions are probably applicable only to that portion of the open prairie lying between the 104 th and 110th meridians. In proportion as the average rainfall of other areas is greater than that at Saskatoon, the breaking of the prairie land or the grass land may very profitably be delayed. In the most humiel parts August breaking or even spring breaking may be (oroppeel with some success.

204. Seeding on Breaking Done the Same Season.The newcomer naturally desires a rop as soon as possible after taking up land. In the more humid parts a 
fair crop on the average may be obtained by good breaking done early enough to seed it about the last of May to an early-maturing erop. In the drier parts such a practice will only result in a profit about once in four years, the reason of the low return being the lack of moisture and available plant food in the soil from the previous year. In the more moist parts oats, barley and potatoes are frequently grown on breaking done the same season, but the practice even in these areas is to be encouraged only where the land can be well prepared by being broken not less than four inches deep, packed and disked and harrowed to form a good seed bed.

Where the rainfall is low and the evaporation great sowing a grain erop on spring breaking is not a good practice. It not only is a losing proposition three times out of four, but the land so used is seldom in good condition for a subsequent erop, nor is it likely to give a good yield until it is summerfallowed. In the dry parts flax is the erop generally used at present for sowing on breaking. Potatoes are sometimes grown on such land for home use, but such preparation is inadvisable for a large acreage of this erop. Oats also are oreasionally grown on spring breaking for sheaf feed. Corn is seldom used on spring breaking, hut mulike the other crops mentioned it will do cuite well and at the sane time leave the land in far better condition for a subsequent crop than any of the others montioned.

205. Native Perennial Plants in Stubble Fields.-The long-lived peremial plants commonly found growing in prairie sod are often the ehief causes of low vields in stubble fields. (Quack grass, sweet grass and rose bushes are three widely spread member's of this group. Such perennials are reproduced hy creeping roots as well as 
by seed and ean be controlled only by plowing. Plowing in a dry time is more effective than plowing in a wet season. To kill these plants in prairie sod it is often necessary to plow twice, or to "break and backset". To kill them when present in stubble fields either of two methods may be used: (1) fall plow and leave loose over winter, or (2) spring plow and sow thiekly at once to a leafy erop like oats or barley. If present in land to be fallowed two plowings are advisable-shallow in fall and deep the following summer or shallow in late spring and deeper in late summer.

\section{Plowing When the Soil is Too Wet or Too Dry.-} When a soil is plowed when either too wet or too dry its physical eondition may be seriously injured. The damage resulting from such a eause can seldom be remedied by tillage and is freqnently not repaired by the weathering ageneies until it is too late to get a good erop. It is true that many heavy soils when left in this condition "slake down" after rains and after the low temperatures and snows of winter; but some do not, and often the rains and snows of winter are very searce and fail to aecomplish the leavening inflnenee of normal or wet seasons.

This injury is seldom serious on fallowed fields that are too wet or too dry when plowed for the reason that the weathering ageneies have time to either partially or wholly repair the injury done by man in his untimely operations. Medium and light types of soil seldom suffer serious physieal injury from this cause but heavy loams and elays frequently do. On some of the lieavier soils in the drier parts fall plowing that is done when too dry turns up in chunks and dries out and often eannot be worked down well enough to give good results 
the following year. The "stubbling in" of fields is generally an undesirable practice but its chief justifieation in the minds of many farmers lies in the fact that there are times and conditions in some of our medium dry areas when land is put out of eondition by fall plowing and, as a result, gives disappointing yields.

For economic reasons man must plow when time permits and this may not be the best time. Nevertheless, the condition of the soil at different seasons of the year and in different years should be an important consideration, when planning the season's operations.

\section{Plowing Under Heavy Stubble or Coarse Manure.-} These substances when plowed under add eonsiderable organie matter to the soil but they do not decay rapidly in a dry elimate and may therefore leave the soil so loose that the upward movement of moisture and the downward growth of plant roots is interfered with thus sometimes resulting in a deereased vield of the first crop after the applieation. This is one of our difficult problems. Continuous grain-growing dissipates organie matter; and eoarse organic matter unless well intermixed with the soil and firmly packed down may injure the eondition of the soil.

When organic matter is badly needed as on the lighter types of soil and those that drift neither stublble nor manure should ever be burned, but when either is plowed under the land shonld be worked down to a firm eondition. Manure should never be applied thiekly for grain erops in the Prairic Provinees. Ten loads per acre on a forty-acre ficld is much to be preferred over twenty loads per are on a twenty-are field.

208. Too Late Plowing of the Fallow.- In tests conducted at Saskatoon the rield of wheat decreased at the 


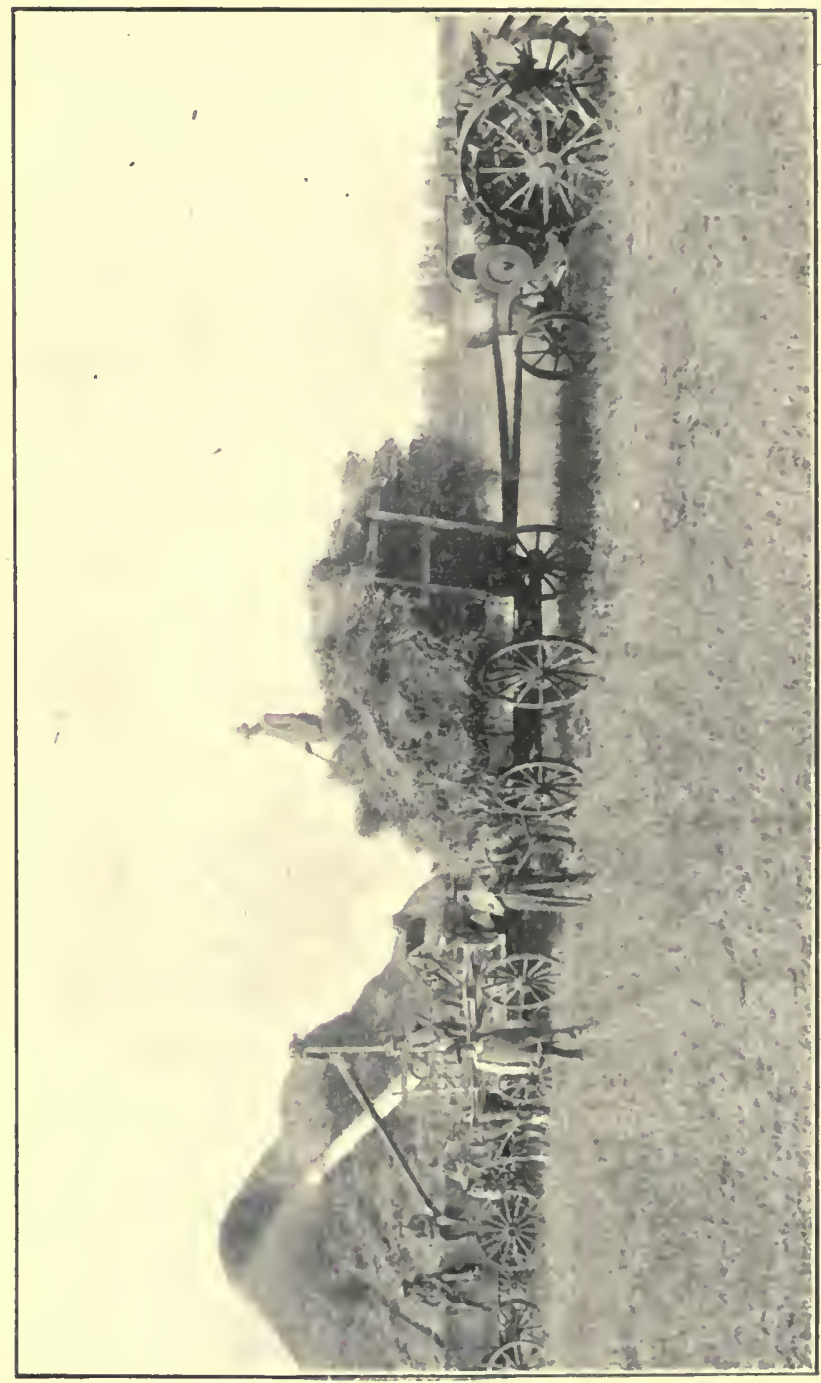

욜 
rate of approximately one bushel per acre for each week's delay in plowing the fallow after the tenth of June. It was quite apparent that the longer the fallow was left unplowed after weed growth commeneed the less moisture there was eonserved and the less available plant food developed.

On very weedy soils it is generally advisable to get the weed seeds germinated before plowing the fallow. This often neeessitates a delay in plowing. In such eases the bad effeets from delayed plowing will be lessened if the weeds and volunteer plants are kept down by some form of surface cultivation such as disking or eultivating. On soils that drift easily late plowing of the fallow may be advisable. (See "Objeetions to Fallowing" and "Defense of Fallowing" in Chapter X).

209. Weeds.-Space does not permit of more than a brief reference to this point. The subject is, however', fully diseussed in Chapter XII. At this time we shall refer only to the principles of weed eontrol, the first of which is that annual weeds like wild oats and the common mustards ean be eontrolled by preventing them from seeding; the second that biennials ean be controlled by plowing the land every year; the third that perennials can be eontrolled by preventing them from seeding and by killing the established plants by tillage; and the fourth that eradicating weeds is of little piractical value if others are introduced to the farm and sown with the seed, or distributed in any other way. Dozens of systems or combinations of practices are used and reeommended for weed control. But all eontrol methods trace back to one or more of these fundamental principles.

210. Insects.-Insects do much less damage to our crops here than they do in milder climates. Yet we are 
by no means free from their visitations. When any species is found to be increasing the methods of control may take any one or more of three forms:-first, the prevention of its reproduction or its spread; second, its destruetion by poisoning if it is a "biting" insect; and third, its destruction by chemicals that kill by contact if it belongs to the "sucking" insects. In some cases none of these plans of attack are successful and other means of destruction are necessary. The common insect pests of the West and their control are very ably and plainly diseussed by Mr. Criddle in Chapter XIV of "Crop Production in Western Canada", and by other" entomologists in bulletins that may be sceured free of charge from the Dominion Department of Agrieulture at Ottawa or from any of the Provincial Departments.

211. Plant Diseases.-The most common diseases affecting grain erops in Western Canada are smut and rust. Flax wilt and certain fungous, bacterial and physiological diseases of potatoes and other erops also take an annual toll from the farmer's profit. Rust cannot be controlled but its ravages may be lessened by the use of rust resistant varieties as well as by all those cultural practices that result in earlier maturity. The eradication of secondary hosts of the plant such as the barberry" and buckthorn lessens the probability of the appearanee of the disease. The grain smuts, except the loose smuts of wheat and barley, can be lessened or entirely prevented by the formalin treatment of the seed. The loose smuts referred to ean be controlled by the hot water treatment of the seed. The physiological diseases can be largely prevented by the choice of suitable varicties and the use of healthy seed. The bacterial and fungous diseases can be controlled only by the use of discasc-frec 
seed on a healthy soil or by chemical or physical treatment to destroy the bacteria or fungi present.

212. Heavy Spring Frosts.-In Western Canada most of the grain erops must be sown before danger of spring frosts is past. The only means of lessening the damage from such late spring frosts as may come are, first, to have seed of strong vitality in order that the young plants may have the greatest possible chance to recover, and secondly to have the soil in the best possible condition in order that the weakened plants may be well supported in their efforts to recover.

Damage may be prevented to some extent by somewhat later seeding and by seeding the hardiest kinds first and the tenderest last. But with grain erops especially it is generally wise to risk the spring frosts rather than to sow late and run the danger of fall frosts. The latter do very great damage oceasionally, but spring frosts seldom do serious harm to cereals except when accompanied by a long period of dry weather or by soil drifting. If the tender crown is exposed by blowing the effect of spring frosts may be disastrous.

In order of hardiness in spring the eereals rank as follows:-Rye, wheat, oats and barley. Flax is not less tender than oats or barley, but if frosted, does not recover so well on aceount of its habit of branching above ground. It is therefore not usually sown until after the eereals. Peas withstand spring frosts quite well but if injured recovery is much slower and less complete than with the grain erops. Corn and potatoes are very tender but potatoes will recover from frosts that kill eorn.

213. Hail Storms.-This is one of the factors affecting crops that man has no power to control. The only way in which he can play safe is by insuring his crop. It is 
seldom that more than two or three per cent. of our crop is damaged by hail. It is true that the average man pays more in premiums than he gets out in awards for hail damage but it is equally true that many minsured farmers have gone bankrupt because they could not stand the loss of a crop.

The justification for insuring against hail is not in the probability of getting back more than is paid in, but rather of insuring one's self against serious inconvenience or even bankruptey in case of loss of orre or more crops.

214. Hot Winds.-The hot winds that oceasionally oceur in southern Alberta and sonthwestern Saskatchewan increase very greatly both the evaporation of moisture from the soil and its transpiration from the leaves of plants. If the veloeity of the wind could be economically lessened in any way, such as by using wind breaks, much damage conld be prevented. In actual practice the only ways of lessening the amount of injury from this source are to store as much moisture as possible in the soil, to use drought-resistant or drought-avoiding crops and to follow as efficiently as possible the established practices of "dry farming". In the very warm parts of the driest areas the use of early maturing eereals such as winter rye offers much promise as a result of partial avoilance rather than resistance to hot winds.

215. Dry Seasons.-The average precipitation in the West is about sixteen inches which is less than one-half of that reeeived in the corn belt of the C'nited States, or in Ontario, or in many parts of England. The monthly distribution of this precipitation is very favorable; nevertheless the low rainfall eanses more low yields than any other factor at the present time. Since we ramot 
control the elimate it remains for us to conserve as mueh as possible of the limited moisture that falls. Every extra ineh of moisture that ean be stored and eonserved in the soil means on an average a possible inerease of two to four bushels of wheat per aere. (See Chapter X).

216. Fall Frosts.-Low temperatures in early fall frequently work serious injury to all grain and other erops in the northern areas and occasionally also in other parts of the West. Our growing season is short and we eannot control the temperature of the atmosphere. We can lessen the damage from frost only by putting into use those practices that result in avoiding frost and by growing crops that take little or no injury from low temperatures. Among these practices are:-(1) paeking the land, (2) thiek seeding, (3) using early elasses of grain such as oats, barley or rye, (4) using early varieties of grain such as Prelude, Ruby or Red Bobs wheat; Sixtyday, Orloff or Daubeney oats; Early Six barley; Long Stem flax; and Early White peas, (5) less frequent fallowing, (6) shallower plowing for the fallow, (7) later plowing of the fallow, (8) pasturing the fallow, (9) early seeding, (10), the use of press drills, (11) growing frost resistant (rops such as Western rye grass, brome grass, grain crops for hay and Swede turnips for sueeulent winter feed, and (12) going into mixed or stoek farming. The first ten of these praetiees aid us in avoiding frost, the last two enable one to farm so that serious injury will not result from this cause. 


\section{CHAPTER XV}

\section{THE MANAGEMENT OF SPECIAL SOILS}

In Western Canada there are a number of soil types which differ from what may be eonsidered normal soils. These generally require some special treatment for best returns. Although most of these soils have not been studied seientifieally it has been thought advisable to add a brief diseussion of their peeuliarities and the methods now followed by farmers in managing Drifting Soils, Alkaline Soils, Loose Top Soils, Burnt Out Soils, Poor Soils and Cold Soils.

\section{Drimting Solls}

Soil erosion as a result of wind action is one of the most serious problems facing the farmer on some types of soil in the open plains region of the West. It is the first and most emphatie evidence of either poor soil, unsuitable tillage or soil deterioration. During the past three years it has been responsible for the partial or complete destruetion of thousands of acres of erop in many different portions of the plains area.

217. The Damage Caused by Soil Drifting is evideneed not only in injury to the erop that may be on the land but also to the soil itself. The seed may be uncovered or blown out of the ground and the young plants may be 
killed by having their roots exposed, or by being covered by the drifting particles, or by abrasions resulting from the long eontinued impingement of the drifting particles against the tender tissues of the plant. The soil itself is injured by the removal of mueh of the surtaee or more productive part. Aside from these more or less general effeets of soil drifting there are other objectionable features such as the possible serious injury to adjoining crops or fields, the spread of weeds and the interferenee with traffic as a result of the aceumulation of drifting soil in road allowanees.

\section{The Chief Factors Favoring Soil Drifting are a fine} textured soil, low precipitation and frequent high winds in early summer before the land is protected by the growing crop. When to these are added too mueh or musuitable surface tillage, and a system of farming whieh is wasteful of soil humus and returns little or no organic matter to the soil, we have a combination of eonditions that is responsible, not only for the large losses from soil drifting that have already occurred, but also for preparing the way for still more serious losses in the future if some radieal ehanges are not made in the methods of tillage and eropping heretofore practised in the affected areas. The greatest damage from this cause is to be observed in sonthern Alberta, portions of western and southern Saskatehewan and in southwestern Manitoba.

- 219. The Chief Causes of Soil Drifting are a highl wind velocity and the low cohesion or binding force of the exposed soil particles. The wind velocity as well as the frequency of high winds and their general direction is a climatic eondition which camnot be controlled; lence man's only recourse is, (1) to increase the cohesion of the 
soil particles or their ability to hold togetler and (2) to reduce the exposure of the surface soil by some form of protection.

220. The Means Employed to Prevent Excessive Damage from soil blowing therefore fall into two groups, (1) those that increase the resisting power of the soil, and (2) those that protect the soil surface from the wind. Among the methods used to increase the power of the soil to resist the wind are, (a) increasing the moistme content, (b) increasing the organic matter eontent, and (c) modifying the strueture of the soil. The protection of the soil surface from the wind may be accomplished by: (a) growing a protecting crop, (b) letting the stubble of one crop remain until shortly before the time of seeding the next erop, or, as with corn stubble, through the whole of the next erop season, (e) applying manure or straw to the field, and (d) providing artificial protection such as the growing of windbreaks. We shall take time for a detailed discussion of only the more important of these practices.

221. Increasing the Moisture Content.-When a soil is moist its particles are not as likely to become separated and blow away as when the soil is dry. 'This fact is of value chiefly to the farmer on irrigated land where water may be applied at will. Tnder dry land conditions it becomes of value only in so far as one may by keeping the surface soil firm, also keep it moist to within a very short distance of the surface. The chief value of packing, in. the control of soil drifting, is to be found in the fact that it aids in bringing moisture from bolow to the surface soil, thus increasing the resistance of the particles to the wind. On the other hand if there is not a fair supply of moisture in the lower soil, the breaking up and 
levelling of the coarse surface particles by the packer will tend to eneourage soil blowing. For this reason paeking is not a desirable practice in the control of soil drifting on all types of soil.

222. Increasing the Organic Matter Content.-This is the ehief and probably the most permanent means of lessening the danger of soil drifting. The organic matter content may be increased, (1) by growing peremnial or biemial hay erops, (2) by applying farmyard manure, or (3) by plowing under green erops. The choice rests between (a) growing grass crops, which in some parts are not considered profitable, or (b) going into stock or mixed farming and hauling manure to the land, or (c) plowing under green crops, which has never been shown to be profitable under semi-arid eonditions, or (d) doing all of these things.

The use of hay erops for the purpose of adding humus or root fibre to the soil results in, (1) improving the soil as a result of their dense root systems, and (2) providing forage for stock from which manure for further improving the soil may be obtained. The low yields of hay from peremial grasses under semi-arid conditions is well known, nevertheless the use of such hay and pasture rrops furnishes what is probably the best means of maintaining the organie matter of much of our lighter soils. Brome grass, owing to its very dense root system, is probably the best for this purpose. Sweet elover promises much, not only as a forage crop but also as a soil improver. It has one advantage over brome grass in that it is a lecume. It therefore leaves the soil richer in nitrogen than does brome grass, but the latter probably leaves more root fibre.

The ehief value of mamure is not in its content of plant 
food; the organic matter which it contains inereases the power of the soil to hold moisture and to resist blowing. On drifting soils the only argument against the use of manure when intelligently applied is the cost of applying it. 'The application of manure as a surface dressing on the more exposea portions that are likely to blow first is a preventive measure that should come into general practice.

The plowing under of weeds in the fallow year, or the early spring growth of sweet clover or of the perennial grasses, is probably the only green manuring it will be found profitable to practise in our dry areas at the present time. The growing of green crops through a whole season in order to have a large growth to plow under to increase the organic matter content of the soil will not likely ever come into general use in the West, for the reason that the organie matter thus added to the soil is seeured at the expense of an enormous quantity of soil moisture which is itself generally the limiting factor in crop yields. On soils that are low in organic matter in areas of light rainfall, it is questionable how far this praetice may be earried before its waste of soil moisture will result in making the remedy more to be feared than the disease.

223. Modifying the Structure of the Soil.-Soil drifting occurs chiefly on the fine textured soils-the sandy types and the heavy elays that slake down to a fine powdery eondition on top. The fallow generally suffers the most, although fall plowed land is not free from erosion and spring plowed land on some soil types oeeasionally blows. The smaller the soil particles are and the drier they are the greater the probability of their drifting. The problem is therefore one of preventing the soil becoming too fine aud too dry ou top. 
The drying out of the top layer cannot be prevented but the formation of a fine "dust" mulch may be-at least on most soils. The use of the unfortunate term "dust muleh" in so mueh of the Western Canadian and Ameriean agrieultural literature, is responsible for at least a portion of the excessive drifting that has oecurred in reeent years. Thie "dust" muleh has no place in the agrieulture of any dry country where high winds prevail. A rough eloddy surface developed by deep eultivation and preferably left in small ridges by a cultivator is to be preferred.

On drifting soils the eultivator should take the place of the dise and harrows on the fallow field. Harrowing onee after the plow, in order to level the surface, is all the harrowing sueh a fallow needs if the soil is prevented from baking or eraeking and the weeds prevented from growing by the use of the eultivator. More eare in plowing in order to seeure a level surface, and the use of the packer (preferably the sub-surface type paeker or a dise run straight) behind the plow, are practices that are making harrowing less necessary and are proving to be more effieacious in lessening soil drifting. A ridged surface sueh as is left by the eultivator provides a refuge for the fine particles in the bottom of the narrow ridges, and in practice is found to result in less blowing and in the production of greater returns than a smooth surface. Working the soil when it is dry should be diseouraged. When it is slightly moist below the surface a more gramular or lumpy top can be developed than if tilled when dry. On smooth fields that are free from stones the revolving rod eultivator ofters much promise. On the lieavy clays of the Regina plains enltivating the fallow in the spring with a narrow tooth eultivator is found to lessen drifting. 
The use of the press drill leaves the soil in better condition to withstand the effects of the wind than the use of most other types, although on some soils the hoe drill has been found to give very satisfactory results. The

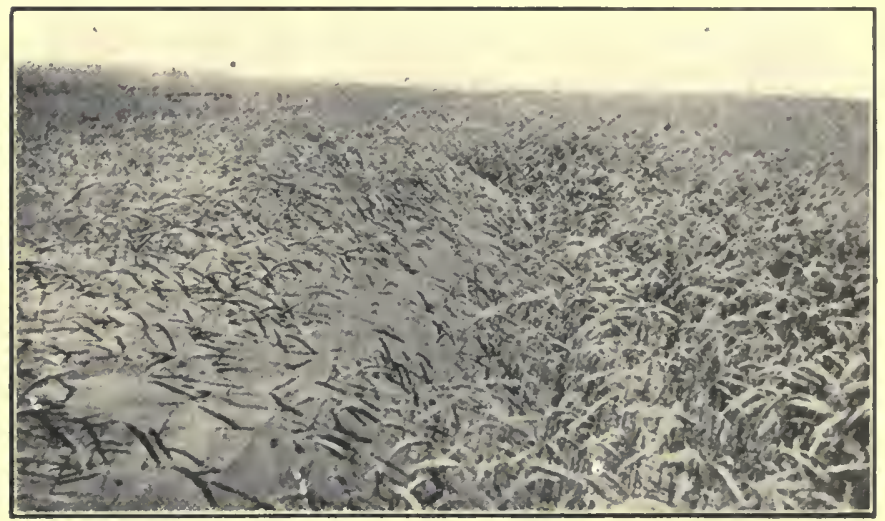

Fig. 92.-Winter Rye Lessens Soil Drifting.

On the left a field of oats was completely destroyed by drifting. The rye was unhurt, except for 10 or 20 feet along the edge where the soil from the oat field blew into the rye field.

single dise drill is particularly undesirable on soils that drift.

Shallow soils or those having a sandy or gravelly subsoil or those having a defieiency of organic matter in the subsoil should not be plowed deep, or they will soon begin to blow. The surface layer of such soils is richer in organic matter and therefore murch more resistant to the wind than the lower layers.

224. Growing Protecting Crops.-The most serious drifting oceurs in May before the spring sown crops cover the ground; but winter drifting is not $13100 \mathrm{mmon}$ in yoars of light suowfall following a dry autumm sea- 
son. In those areas where drifting is quite common the only fields that ean be depended upon to wholly resist the wind aetion, under severe eonditions, are those that are protected by a crop or by unplowed stubble.

225. Perennials as Protecting Crops.-The best protecting erops, although often the least profitable, are the peremnials. Among these the grasses are to be preferred, although alfalfa and sweet elover (a biennal) are equally as good soil protector's. It is very seldom that erops sown on land broken up out of sod suffer from soil drifting. In 1919 such land produeed almost an average yield at Saskatoon while many crops on fallow and fall and spring plowing were partial or eomplete failures as a result of high winds and dry weather.

226. Winter Rye Lessens Drifting.-Another commonly grown erop but one less sure of furnishing the protection needed is winter rye. This erop, like the perennials mentioned, may be sown in or following the rainy season when the soil seldom blows, and by covering the ground in May is, like the others, likely to lessen or entircly prevent any blowing. The question of growing winter rye is one that deserves consideration by all farmers living in soil drifting areas. Where drifting interferes with wheat raising to such an extent as to make it unprofitable, winter rye, in many cases, may be substituted to advantage. Is a commercial arop, however, rye generally sells for twenty-five to thirty per eent. less than wheat, so that where the latter ean be satisfactorily grown rye cannot compete with it as a profitable crop. The illustration (Fig. 92) shows very convineingly the relative resistance to drifting, of land proterted by winter rye as compared with that seeded to oats, a spring sown rrop. 
227. Late Sown 0ats for Soil Protection.-Where the eonditions are not so serious as to require the use of one or more of these crops, but where some protection of the soil is desirable, a very thin seeding of oats or other cereal may be sown on the fallow in late July or early August and lightly pastured if neeessary. 'These plants, of course, die in winter, but the roots and leaves remaining furnish considerable protection against the high winds the following May. An objection to this practiee is to be found in places where biennial weeds are prevalent. If the latter start after the eover erop is sown in July they will, of eourse, be present in the erop the next year, as no opportunity to kill them in the fall offers itself, the ground being occupied by the cover erop which would be destroyed if cultivated. A volunteer growth of grain or annual weeds in late summer has a similar effect to the sowing of a thin erop of oats, but is subject to the objections pointed out above, viz, the possible presence of biennial weeds that will live over and appear in the next erop.

228. Stubble as a Soil Protector.-Where soil drifting oecurs on fall plowed land in winter or in spring two alternatives present themselves, spring plowing or "stul)bling in." In much of the very dry portions of the plains region, even aside from the question of soil drifting, spring plowing is rather to be preferred to fall plowing. Where these conditions obtain, of course, all ${ }^{\prime}$ the advantages are with the spring plowing because such land is protected in winter and generally blow's less than fall plowing even in the spring. "Stubbling in" is only advisable on land that is free from weeds and grass and that is in good physical condition. In the dry parts and on new land it is more frequently followed than 
elsewhere. Such fields, of course, benefit as a result of protection in the early summer as well as in the preceding winter.

229. Corn Stubble Lessens Drifting.-On warm soils in the southern part of all three provinces corn may be

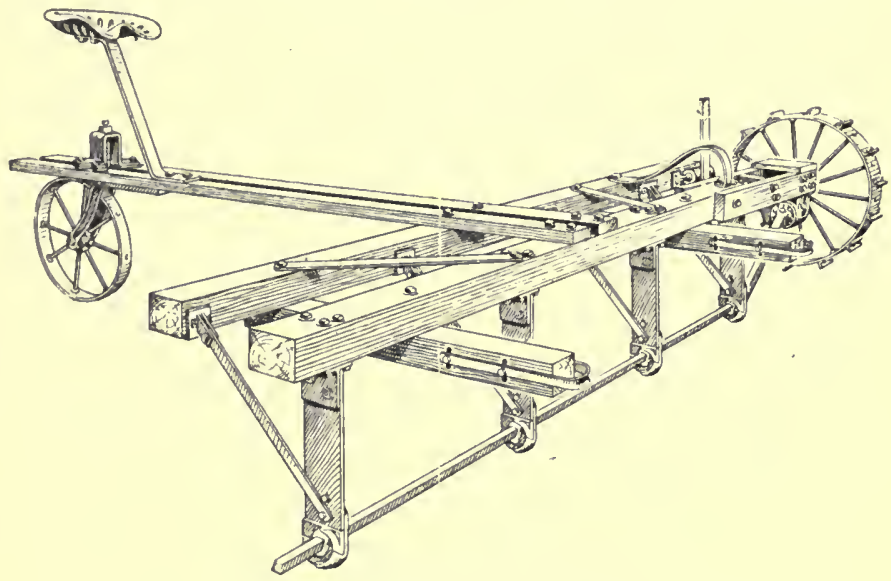

Fig. 93.-Rotary Rod Cultivator.

A new machine that is being tried out on soils that are inclined to drift.

used as a partial substitute for the fallow. Where fallow land in such areas drifts badly, the use of corn as a substitute for fallowing lessens the tendency to drift. Under severe eonditions the corn ground will blow, but frequently the corn stubble furnishes sufficient proteetion to wholly prevent serious injury from this eause. Where corn is grown and the field kept free from weeds, plowing is, as a rule, not necessary or even advisable for the next crop. Disking the corn stubble generally gives better returns. 'This practice results in leaving the corn stubble on the surface of the soil where they form a considerable protection against soil drifting. 
229a. Artificial Protection.-The value of windbreaks such as elumps of trees, hedges, fences, ete:, is in direct proportion to their height and extent. Depending upon the severity of the storm the land adjoining such windbreaks is generally protected from ten to twenty times the height of the windbreak, although instanees lave been reported where such protection is felt over a much greater distance. As a means of lessening soil drifting windbreaks are practicable only for small areas. Nis doubt when shelter of this kind becomes established on all farms the wind velocity will be lessened somewhat, but the cost of planting and maintaining will probably be found to be too great to warrant planting out enough trees to make any appreciable effect on the wind velocity on large farms in the open plains. Where windbreaks such as hedges or fences are used to protect the farmstead or the garden, an outer row, a few rods from an inner one, should be provided in order to form a "trap" for the drifting soil, otherwise the drift will accumulate within the enclosure and become a nuisance in the carrying out of the necessary farm operations.

230. Miscellaneous Practices and Suggestions.-In fields where the soil has begun to blow much ean be done to cheek it by going into the field and plowing either single furrows or narrow strips of four to six furrows from five to twenty-five rods apart, at right angles to the direction of the winds. These raised portions act as cheeks behind which the drifting particles lodge. This is an extreme measure and is only advisable where a small pateh of drifting soil promises to do serious injury to adjoining areas that are not likely to blow if the drifting material ean be kept away from them. 
$\Lambda$ rranging the areas to be seeded in long strips rather than approaching the square will also counteract the injurious effeets of the soil drifting to a eertain extent.

By sowing the grain deeper than usual, thus leaving the soil furrowed, tends to prevent soil drifting and lessens the probability of the seed or the plant roots becoming exposed.

The sandy soils take more permanent injury from drifting and are much less subject to favorable modifieation by tillage than the clay types; the maintenance or increase of the organic matter content by applying manure and growing grass or legume erops becomes therefore of much greater importance with these than with heavier soils.

The introduction of peremnial grasses to the rotation in dry distriets should be made gradually, otherwise there may be diffieulty in adjusting the farm organization to the ehange. It is hardly neecssary to point out that if the eropping system is altered to include the growing of the forage grasses and legumes, provision for the ceonomical utilization of this forage should also be earefully planned, otherwise the benefit to the soil arising from the ehange may be seeured at too high a price.

$\Lambda$ s eurative measures after soil starts to blow there is very little effective treatment that ean be given. Where isolated spots only are affeeted, sueh as light knolls or exposed elevations, spreading manure either in strips or over the whole surface will lessen the injury. Plowing a few furrows in strips a short distance apart on the lee side of such drifting areas, while a very drastie measure, is one that is advisable where a small area of drifting soil in a larger area of good soil is likely to result in injury to the whole if not controlled in the early 
stage of the blowing. The drifting particles that leave such light areas may during the eourse of several days of blowing affect several parts of the field, sinee they move readily from one place to another, doing injury at every move. It thus happens that from one small patch of poor land a large acreage may be severely damaged if drastic measures are not taken in the early stage of the storm.

231. Conclusion.-The fallow is the worst to suffer from soil drifting and the danger is greatest in May but may oeeur in winter. The damage is increased when such surface tillage as disking and harrowing, which tend to make the soil fine and loose on top, is practised; it is lessened by deeper tillage with eultivators which leave the soil in a rough, more or less lumpy eondition, and preferably in shallow ridges. If this treatment is not sufficient to eontrol the drifting a thin seeding of oats may be sown on the fallow in July and August, or in some districts corn may be used as a partial substitute for the fallow. In cise one or other of these fails to produce the desired results, winter rye, which establishes itself in the fall and which has possession of the ground in May, and is therefore likely to prevent the blowing, may be used. Under more serions eonditions of soil drifting it may be necessary to grow perennial or bienniel erops and sow eereals only on the sod land, or to so build up the organic matter content of the soil by using hay and pasture erops and farmyard manure, that when intelligently tilled the land will not be likely to blow.

\section{Alkatine Solls}

The "Alkali" spots so familiar in some districts, and which produce low returns or none at all are the result 
of an aeeumulation of soluble salts of different kinds. In the process of weathering through long periods of time chemieal changes in the soil result in the development of certain ehemieal compounds which are soluble. Some of these are useful to plants but some are harmful. In humid climates the excess is removed by drainage through the soil. In semi-arid and arid climates an aceumulation of the toxic salts oeeurs beeause there is insufficient rain to wash them through the soil. The result is they are slowly moved to the low spots by soil water as it seeks the lower levels, where, on the evaporation of the water the salts remain as "alkali" on or near the surface of the ground.

This condition is found chiefly in countries having a low precipitation, and occurs in areas where the drainage is poor and the evaporation higl. It is a condition that is not general in Western Canada, but is fomnd usually in small patches here and there over the whole West. These patches are invariably found (1) along the edges of old storage basins, (2) in low places where moisture aeeumulates and evaporates, and (3) in "springy" places below higher ground where salt impregnated water oozes from the surface and evaporates. Alkali frequently "rises" and often with serious consequences where too much water is applied in irrigation.

Aecording to Shutt* the eompounds known collectively as alkali comprise chiefly sodium sulphate (Glauber's salts), sodium carbonate (washing soda), sodimm chloride (common salt), magnesimm sulphate (Epsom salts), and oc(asionally the chlorides of calcimm, and magnesium.

*In bulletin on "Alkali Soils", published by Imminion Department of $\mathrm{Agriculture.}$ 
Black alkali is eharaeterized by the presence of sodium earbonate (sal soda, washing soda) although this eompound is almost always associated with one or more of the ehlorides and sulphates mentioned in the preceding paragraph. Sodium carbonate is, as is well known, white, but from the fact that it acts upon and dissolves the decayed vegetable matter (humus) of the soil the inerustation is tinged dark brown or black-henee the name. Water standing in pools on soils impregnated with the earbonate is invariably of a darker color and much resembles a strong infusion of coffee.

232. Why Alkali is Harmful.-It is thought that the harmful effects of alkali result from one or more of four different aetions: (1) the destruetion of soil tilth, (2) the corrosive effect of those alkalies containing sodium earhonate, (3) the withdrawal of moisture from th:" plant cells by osmosis, and (4) the toxic effect of some of the salts.

233. The Reclamation of Alkali Soils.-In the dry lands where alkali spots are found the chief means to improve them are: (1) the application of manure, (2) surface drainage, (3) thorough tillage to lessen evaporation and 14) the use of grass crops where the alkali is bad or the spots too numerous or too large to attempt to reclaim. Manure improves the tilth and thus aids reops to establish themselves. Surface drainage removes the water carrying the alkali in solution and thus prevents a further accumulation of salts.

Thorough tillage aids in lessening evaporation and the consequent rise of alkali with the water as the latter comes to the surface. Manure also aids in lessening evaporation. Thorough tillage and manure, by helping to keep the soil filled with water, help also to wash the 
alkali down to lower levels and to dilute the solution in the surface soil, thus frequently making profitable erop growing possible.

On irrigated land, flooding and under drainage to wash out the soluble salts and earry them away in the drainage water is frequently practised. When the alkali contains sodium earbonate, land plaster or ground gypsum may be applied. This ehanges the black alkali to white alkali, a less harmful form and one that may more easily be removed by drainage. The removal of alkali by mechanieal means is sometimes praetised on high-priced land. Shutt points out also that on certain types of alkali or those consisting largely of magnesium sulphate (Epsom salts) the application of lime or marl before irrigation and drainage is benefieial.

234. The Use of Alkali-Resistant Crops.-None of the important field erops can be grown where the alkali is strong. Rye and barley are reported to be more resistant to alkali than the other cereals. Among wheats the macaroni varieties are said to be the best. Members of the beet family are the most resistant root erops for this type of soil. The legumes as a class do not do well on alkaline areas, although sweet elover is reported to be alkali-resistant. The forage crops or those grown for hay or feed rather than for seed are generally the best to grow on alkali land. Western rye grass and brome grass are eommonly sown and used either for hay or pasture on soils of this nature.

Kearney in a summary of his studies on the alkali resistance of rops states in Bulletin No. 44 of the United States Department of Agrienlture that "most field erops camnot be profitably grown when the quantities of white alkali salts (sulphates, bicalbonates 
and chlorides) in the depth occupied by the roots exceed one per eent, of the dry weight of the soil and only a few resistant species can be expected to give good crops when the quantity exeeeds one-half of one per cent."

\section{Loose ToP SoILs}

This is a local name applied to a peculiar type of very heavy soil which both in the unbroken as well as in the cultivated condition frequentlty carries a loose or spring: layer of soil three or four inches in depth. The vegretation is rather sparse, mostly grasses of a bunchy nature with considerable sage brush in some parts. Very few native trees or shrubs are found growing on it.

This soil bakes very readily after being wet and on drying opens up in large cracks often wide enough to let the plow wheel in to the axle. The rain water and some of the loose particles of soil pass into these eracks and on freezing and expansion later there results the roughened surface popularly spoken of as "hummocks". A eonsiderable area of this type of soil lying west and south of Goose Lake in Saskatchewan was spolien of among the early ranchers as the Saskatehewan desert.

This soil when broken is dark in eolor, the loose spots appearing almost a slate blue. Even in dry weather it seems damp when plowed and if the dry weather eontinues after plowing, the soil of the furrow slice becomes very hard. After rains it "slakes" down forming a loose surface dry on top and wet underneath and inclined to bake and crack in the heat after heary rains. The soil is very deep, rich and very fortile but cold and rather diffieult to till.

235. How Loose Top Land is Broken.-This land is usually broken with rod plows instead of the ordinary 
mouldboard breaker. When the brakine is not done with engines a sulky drawn by five or six horses is used. The fact that so much power is necessary to ent and turu over one furrow gives some indication of the heavy nature of the soil. The use of the heavy float or plank drag or scrubber on the rough surface soon after plowing and before it bakes is beeoming a general practice. This operation is followed, as opportunity presents, by double disking to form a seed bed and aid in killing grass. To finish the season's cultivation a single or double stroke of the harrow is given.

236. The Crops Grown.-Loose top land is frequently infested with wireworms which work havoe with cereal erops if they are sown first, but which injure flax very little. The first crop is therefore generally flax and the common practice is to use cereals as the second crop. Wheat is frequently sown on the flax stubble without any enltivation, although fall or spring disking is also commonly followed. The practices of breaking and the use of flax as the first crop are puite fixed and general but the best preparation for the second crop las not yet been determined to the satisfartion of many.

237. Fallowing Loose Top Land.--Aftel taking two cops, the land is usually fallowed, the plowing being dome with disc: plows. Motor power is in common use. The level land, its feedom foom slonglss and stomes, and the heavy draft all tend to foster this form of power. The plowed land is subsequently cultivated much the same as cther soils. At present dises and drag harrow are extrusively used but cultivaters are being introdirced more and more.

238. The Rotation Used.-The rotation gancrally pracetised is a fallow and two rops, breaking, flax and 
wheat at first, followed by fallow, wheat and wheat, oats or flax is the general rule. The small seeded annual weeds are quite prevalent owing to the use of so much flax. The weed pest together with the relatively low preeipitation, heavy soil and somewhat unsatisfactory yields from fall and spring plowing is tending towards the three year system,-of fallow, erop and crop-with no plowing for the second erop. $\Lambda$ few men are following the two-year system and fallowing half the land each year.

\section{"Burnt OU'T" SOIL}

A peculiar spotted condition of what seems to be otherwise a normal type of soil is to be found in some parts of southwestern Saskatchewan, southeastern Alberta and Montana. It is locally spoken of as "burnt out" land. Areas varying in size from a few feet in diameter to as many rods are found, seattered thinly in some areas and thiekly in others, where in some manner the surface soil to the depth of six to ten inches seems to have been removed. Many settlers are of the opinion that these areas have at some time been "burnt out" leaving the prairie in the spotted eondition it is found in to-day. The more probable explanation is that after a series of dry years with little vegetation on the land, it has become puddled after heavy rains, then slaked down to powder and eventually blown away by the wind. Whatever the explanation, it is clear that the surface soil has gone and that the soil now on top in these depressions appears to be quite similar in texture and eomposition to the subsoil of adjoining normal soil.

Most of these low spots are envered with grass but in a few areas they carry very little vegetation. After 
breaking some of them are reported to be more or less alkaline but many of the "burn outs" are found to be productive. The diffieulty with and ehief objection to them is that the texture is different from that of the good soil, hence the "burnt outs" are seldom in eondition to work when the good land is, and the erop the former produces is either very small or very late, resulting in a lower yield or a lower grade. The diffieulty is one of handling the land effieiently and of getting a high grade of grain.

239. The Management of "Burnt Out" Soils.-The lower levels of the "burnt out" spots and the lack of organie matter in them are the chief causes of inconvenience and loss, and suggest the basis of attack. After a survey of the methods of handling this land the following practiees were found to be used by many of the most suecessful farmers with apparently favorable results:-

1. Levelling with floats and harrows to get some of the good surface soil into the "burn outs", thus lessening the difference in level and improving the tilth of these low spots.

2. Surface drainage to prevent water standing in the hollows too long after rains.

3. Heary applications of manure either plowed under or used as a top dressing.

4. In a few cases shallow fall plowing, left loose, was recommended. Spring cultivation with a spring tooth cultivator or dise harrow seemed necessary in some areas whether the land had been well prepared the fall previous or not.

5. Deep plowing of the fallow, it was frequently stated, resulted in a more uniform and heavier erop.

6. Some men strongly resommented the use of the 
spring tooth cultivator on the fallow in preference to the dise, which seemed to make the soil too fine and thus cause it to rum together more when wet.

The plowing under of green crops, such as winter rye or sweet clover to increase the organic matter supply has not been tried out, nor has the application of slaked lime or fincly ground limestone been tested. It is prob-

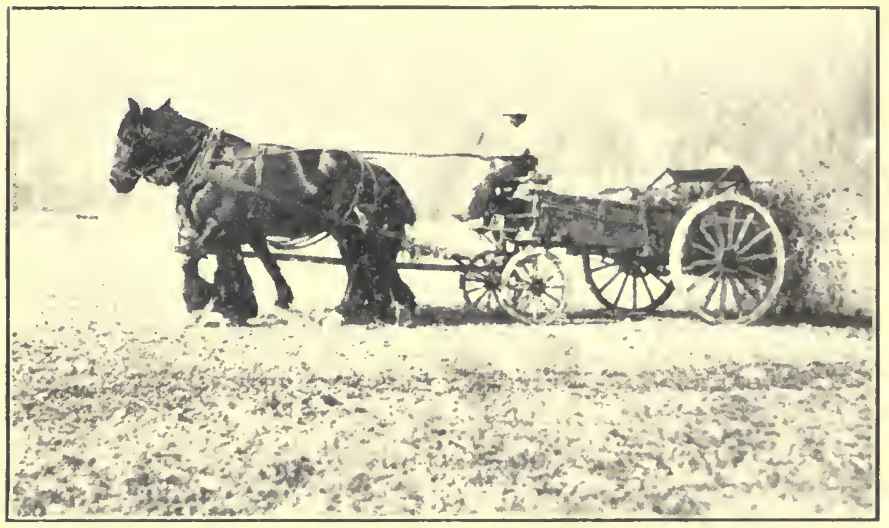

Fig. 94.-Hauling Manure with a Spreader.

The use of fresh manure in thin applications, preferably by a manure ' spreader, is a good practice.

able that while both of these practices might result in some improvement to the soil, it would be at present too costly a procedure for general use by pioneer settlers.

Vigorous floating, planking and larrowing, deep plowing, not permitting the surface to get too fine in the fall, working the land only when in condition, surfare drainage of the low spots by furrows and the application of manure seem to be the most promising methods of inproving the productive power of this type of land. 


\section{Poor Solls}

The soils of Western Canada are far from poor as a rule, but a few small areas of land have been settled upon that never should have been opened for homesteading. In a elimate sucl as ours at this stage of our economic development some of the latter cannot be farmed at a profit, mueh less ean they be brought up to a state of produetiveness onee their virgin fertility is lost.

Many of our soils become "poor" after cultivation for a few years with no return of organic matter. The process is so slow and so gradual that the pioneer farmer seldom notices it. A false sense of security in the lasting power of soils has ever blinded the first generation of farmers to the inevitable result of ruining the land. It is only where one notes the reeords of many years that the truth forees itself home. One instance out of many is sufficient to illustrate this point. The average yield of wheat in Kansas for twenty-five years previous to 1890 was 14 bus. 47 lbs., while for the twenty-five years subsequent to that date it was 12 bus. $27 \mathrm{lbs}$. The average for oats for the first period was 33 bus. 08 lbs., and for the last, 22 bus. 17 lbs.

In the carly rears of cultivation over much of the semi-arid plains of America manuring seldom produced large inereases but after a few years eropping it has invariably been found to produce excellent results. As an example, on the Kansas land mentioned above, where manure produced very little increase in the early years, an applieation equal to $20 / 2$ tous per aére per year during the years 1911 to 1917 increased the rield 7 1-3 bus. or alont one-half more than from mmanured land. Similar results have been reported from many places in 
the older plains States between Kansas and Western Canada.

239A. The Value of Manure.-What has been salid about the advantages of organic matter in Chapter III and in other places applies in a greater degree to manure. The value of this fertilizer is not chiefly in the food

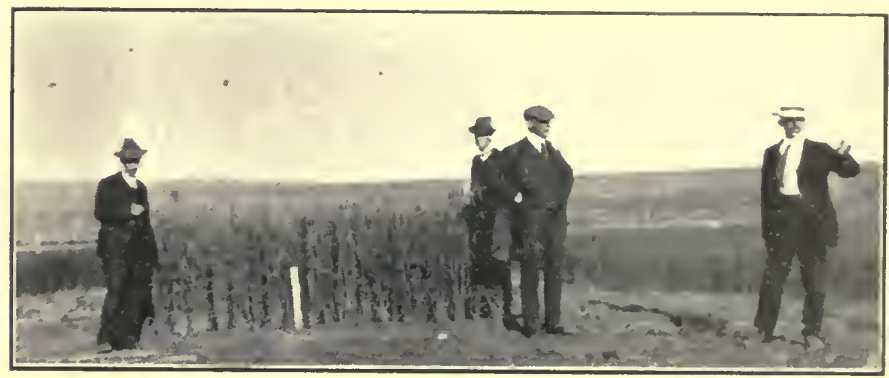

Fig. 95.-Cereal Test Plots at Beaver Lodge, Grande Prairle District, Northern Alberta.

material it earries but rather in its physical and biological effeets on the soil. It not only adds some elements of plant food but it improves the structure of the soil, increases its moisture-holding power, lessens the tendency to blow and, perhaps most important of all, increases the activity and the number of the desirable soil bacteria that perform the important function of making plant food available.

According to Hopkins* "a ton of fresh-mixed cattle and lorse manure contains about 500 pounds of dry matter, 10 pounds of nitrogen, 2 pounds of phosphorus, and 8 pounds of potassium. . . . By leaching and fermentation the dry matter, nitrogen, and potassium are lost in approximately the same proportion, but the phosphorus is lost only about half as rapidly, so that one ton

*In "Soil Fertility and Permanent Agriculture." 
of average yard manure, resulting from perhaps two tons of fresh manure, contains about 500 pounds of dry matter, 10 pounds of nitrogen, 3 pounds of phosphorus, and 8 pounds of potassium, one-half of the dry matter, nitrogen, and potassium, and one fourth of the phosphorus having been lost.

"In an experiment condueted at Cornell University, 4,000 pounds of ordinary manure from the horse stable, worth $\$ 2.74$ per ton for the plant food eontent (at eommereial prices) were exposed in a pile out of doors from April 25 to September 22. At the end of that time the total weight had deereased to 1,770 pounds, worth only $\$ 2.34$ per ton. In other words, the value of this pile of manure was redueed from $\$ 5.48$ to $\$ 2.03$ during five months' exposure. ... In no ease should manure be allowed to heat and ferment before being spread on the land, if its full value is to be seeured."

Manure gives best results when applied thinly and worked well into the soil. It is usually applied (1) as a top dressing for grass land, or (2) plowed in before eorn, roots, potatoes or barley, or (3) on some of the lighter types of soil plowed under in the fallow year. It may be objeetionable (1) when applied thickly in dry areas and plowed under for a erop the same season, or (2) when plowed under on heavy soils in the fallow year. In the former ease the soil may dry out, in the latter the growth may be too rank and weak and the erop may lodge.

239B. The Place of Commercial Fertilizers. - Commereial fertilizer's have not yet demonstrated that they have a plaee in our eropping system. These substances do not, like manure, improve the tilth or physical or biological condition of the soil. They are valuable only for the nitrogen, phosphorus, potassium or lime they 
may carry. It is possible that on some soils the use of one or more of these fertilizers might pay even now, but in the few tests that have been conducted (usually on good soils) they have not produced sufficient increase to warrant their use, except perhaps in truck farming or potato growing. The time will come, no doubt, when it

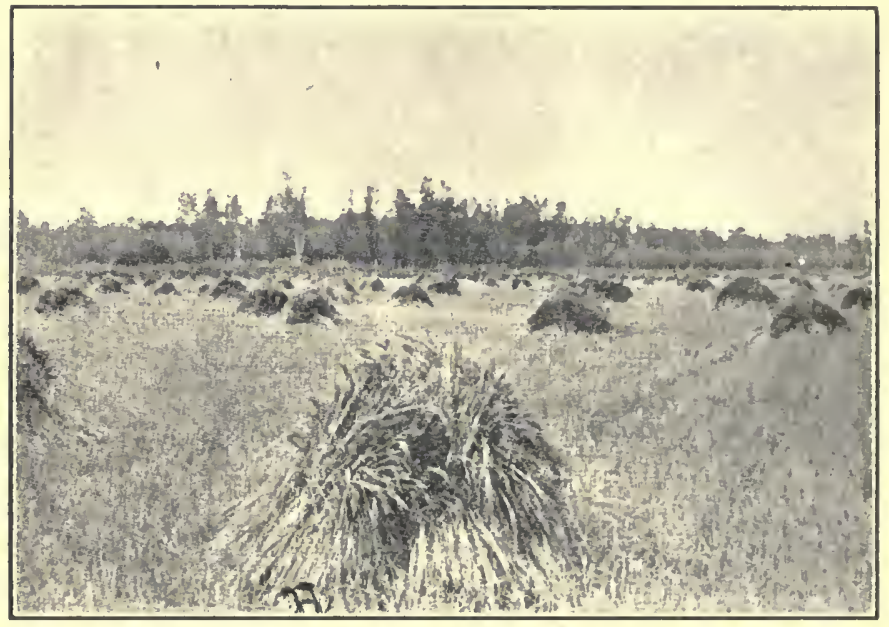

Fig. 96.-Wheat Field at Fort Vermilion, Poace Rivar.

700 miles by trail north-west of Edmonton, Alta.

will be necessary to apply phosphorus, the supply of which in our soils is not high; and we are shipping it away in large quantities in the grain we sell.

Nitrogen can be gotten from the air by growing legumes, and the potash supply in the soil is rery high, but mufortunately there is no means of replenishing the phosphorus supply except by purchasing. It is interesting to uote that the use of phospluate fertilizers in some places results in an earlier crop of grain. 


\section{Cold SoILs}

The practice of agriculture in warm climates is based on the experience of four thousand years or more. Likewise the practices of erop growing under irrigation have developed through an equally long time. Even modern dry farming practices are based upon the experiences of more than a generation. But the growing of crops in elimates as far north as the northern settlements of Western Canada and Europe is a eomparatively recent movement, and it enjoys neither the acemmulated experience of years nor the benefit of such searching scientific investigations as has the agriculture of other climatic zones.

When the amount or the condition of the plant food in soil limits the yield, as in most warm humid areas, methods for permanently maintaining ol increasing the yields are known. Similarly on dry lands where water limits the yield the science of dry farming has been quite thoronghly worked ont. But in northern regions and in high altitudes where the growing season is short and where low temperatures limit the vield there is little to be learned from the investigations of science and still less from the practices of older agricultural countries. This medus that suceessful methods have yet very largely to be worked out for the "rop grower along the northern alges of sottlement.

\section{C. Some Practices of Northern Agriculture.--} At the present time some of the chice platetices beine followed where low tempelatures limit the vield aro as follows :

(1) Ranching, which permits of the extensive use of the native vergetation anel such frost-pesistant opops as

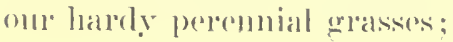




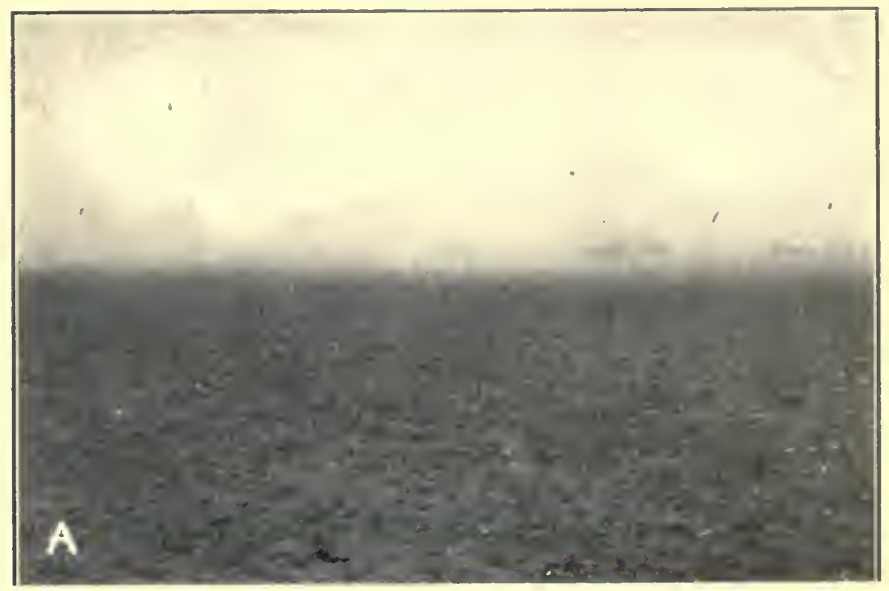

Fig. 97.-The Windstorm at its Height.

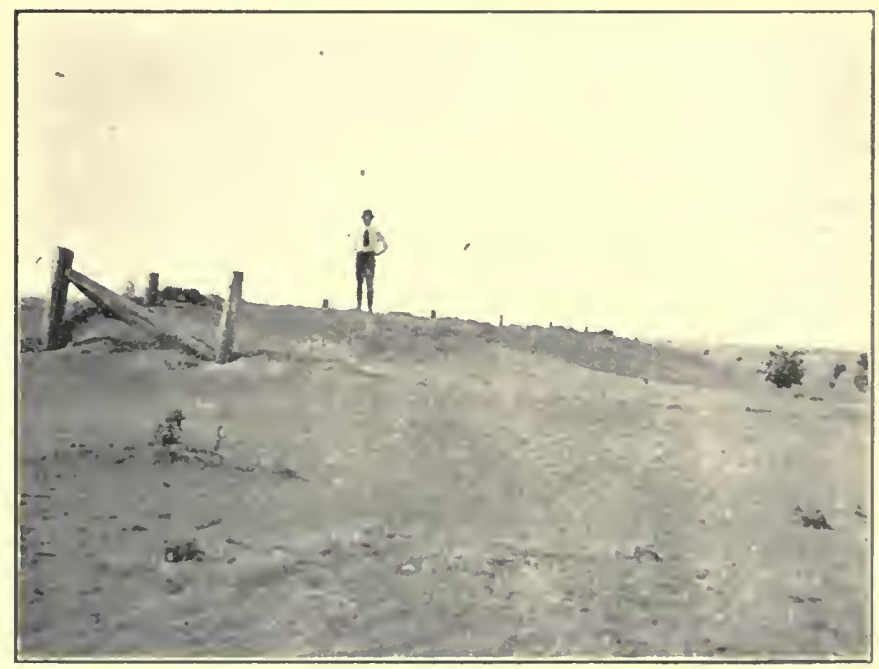

Fig. 97B.-After the Windstorm. 
(2) Mixed farming, which may provile for the utilization of the native vegetation, and whieh permits the use of (1) grain erops for hay, (2) Swede turnips for succulent winter feed, and (3) the profitable use of frostdamaged grain as feed.

(3) The use of early elasses of grain crops, such as oats, barley or rye in preference to wheat; and the use of early varieties such as Prelude or Ruby wheat; sixtyday, Orloff or Daubeney oats; Early Six barley and Early White peas.

(4) Soil management practices that result in earlier germination or earlier maturity such as (a) packing the land, (b) less frequent fallowing, (e) shallow plowing of the fallow, (d) later plowing of the fallow, and (e) the use of manure to warm up cold soils.

(5) Thicker seeding- $-\mathrm{N}_{0}$ combination of practiees will result in preventing damage to grain erops from summer frosts, but a few days earlier maturity may lessen the probability of injury from fall frosts. Thick seeding results in somewhat earlier maturity of the erop. 


\section{CHAP'TER XVI}

\section{LESSONS FROM EXPERIENCE}

The Great Plains Region of North America inchudes a large part of the Prairie Provinees of Canada and most of the United States lying between the Mississippi Valley and the Rocky Mountains. This large area includes many soils and elimatic eonditions and its problems therefore, are not the same in all parts. They are, however, suffieiently similar to justify the inclusion under one eover of the experiences of the settlers in its different parts. It has therefore been thought wise to ask some of the leading agronomists in this large area to summarize the experience of the best farmers and the results of experiment station work in their respective states and provinces. These summaries, for which the author is very much indebted to the writers, are as follows:-

Dry Farming in the Great Plains Region of the United States, E. C. Chileott, Agrieulturist in Charge of Dry Land Investigations, Washington, D.C.

Dry Farming Practices in Kansas, L. E. Call, Professor of Agronomy, Manhattan, Kansas.

Dry Farming in Nebraska, W. W. Burr, Professor of Agronomy, Lincoln, Neb.

Dry Farming Praetiees in North Dakota, Manley Champlin, formerly Associate Professor of Agronomy, Brookings, S.D. 
Dry Farming Practices in North Dakota, W. R. Porter, Superintendent of Demonstration Farms for North Dakota.

Dry Farming Practices in Montana, Alfred Atkinson, President Montana State College of Agrieulture.

Dry Farming in the Red River Valley, T. J. Harrison, Professor of Field Husbandry, Manitoba Agrieultural College, Winnipeg.

Dry Farming in Western Manitoba, W. C. MeKilliean, Superintendent Experimental Farm, Brandon, Man. Dry Farming Practices in the Park Belt of Alberta, G. H. Hutton, Superintendent of Agrienlture and Animal Industry, C. P. R., Calgary.

Summer Fallow In Southern Alberta, James Murray, Superintendent of Farms, Noble Foundation Ltd., Nobleford, Alberta.

\section{DRY FARMING IN THE GREAT PLAINS REGION OF THE UNITED STATES}

A Summary of Some of the Conclusions Drawn From the Investigations Conducted bY the Office

of Dry Land Agriculture, United States

Department of Agriculture, Into the

Best Method of Managing Lind in the Great PlaAins Area.*

By E. C. Chilcott, Agriculturist in ('harge.

\section{Summer Tillage.-}

Spring Wheat:-Summer tillage without crop has given the highest average yields of any method under

*'Ihe references in parenthesis refer to the U.S. D. A. Bulletius in which may be foumd the evidence upon which the conclusions herewith reproduced are bascel. 
trial at 12 of the 14 stations. Howerer, on aceount of: its high cost due to extra labor and alternate year cropping, it has not been the most profitable practice. (Bul. 214, - p. 43-11).

Winter Wheat:-Summer tillage has given the highest average yields of any method under trial at 11 of the 13 stations. However, on account of its high cost due to extra labor and alternate year cropping it has not netted the largest returns except at Huntley (Montana). (Bul. 595, - p. 35-10).

Oats:-Oats following summer tillage produced the highest average yields at all stations except Hettinger (N.D.) where the yield was exceeded only by that on disked eorn ground. While the expense of the method has prevented its being the most profitable the degree of insurance which it affords against failure of the feed erop might justify its practice in oat production in at least some sections of the Great Plains. (Bul. 218-p. 42-9).

Barley:-The highest average yields at 11 of the 14 stations have been by summer tillage. On the average it increased the yields nearly one-half over those produced on land cropped: in the preceding year. On account of its cost, it has not been the most profitable method of preduction. (Bul. 222-p. 32-3).

Corn:--Summer tillage has slightly increased the grain yields at all except three stations and has materially increased fodder yields at the three southern stations. The increased yield's, however, have not been sufficient to make it the most profitable method at any station except Seottsbluff (Nebraska). (Bul. 219-p. 31-3).

241. Corn or Sorghums vs. the Fallow.Spring Wheat:-Disked com ground has given con- 
sistently high yields. This, together with the low cost of preparation, has resulted in its showing the highest average profit or lowest average loss of any of the methods tried at all fourteen of the stations except one. These profits are based on the assumption that the corn erop was so utilized as to pay for the cost of its production. (Bul. 214-p. 43-7).

Oats:-At Garden City (Kansas) and all stations north of North Platte (Nebraska) disking corn ground has been productive of higher average yields of oats than either fall or spring plowing. At North Platte (Nebraska), Hays (Kansas), Dalhart and Amarillo ('Texas), it vielded either the same as one of them or its place was intermediate between the two. (Bul. 218-p. 41-5).

Barley:-At ten of the fourteen stations under study; disked corn ground prodnced higher yields than from either the fall plowing or the spring plowing of barley stubble. It has been the most profitable method under trial at all the stations exeept Hettinger (N.D.). (Bul. 222-p. 32).

Winter Wheat:-Disked eorn ground las given consistently high yields. This, together with the low eost of production, has resulted in this method showing the highest average yields of any of the methods at all of the 11 stations where it has been tried, except at Huntley (MIontana) and Amarillo (Texas). These profits are based on the assumption that the corn erop was so ntilized as to pay for the cost of prodneing it. (Bul. 595-p. 35-p).

\section{When Disking May Be Substituted for Plowing-} These investigations have shown that when the corn crop lias been grown on properly prepared land and kept free from weeds, the lant does not require plowing in preparation for a following erop of small grain. Wheat, oats 
and barley have usually given better yields on disked eorn land than upon land that has been plowed. This, together with the fact that disking is cheaper than plowing, makes disking eorn land generally the most profitable method of preparation for small grain. Discing potato land is probably as good a preparation for small grain as disking eorn land, and there are undonbtedly other intertilled crops such as peas, beans and peanuts that will serve the same purpose. The sorghums, however, do not leave the ground in as favorable a condition for the erop that is to follow as the other crops mentioned. (Bul. 268-p. 22).

243. The Use of the Lister in the Fall.-The practice of ridging with a lister as a substitute for fall plowing, and eultivating down level without the use of a plow in the spring has been tested at most of the stations as a preparation for all of the small grain erops considered in this bulletin exeept winter wheat. It has usually produced as good or better yields than fall plowing. Its lower eost has made it in many instanees nearly or quite as profitable a method as disking eorn stubble. In addition to its low cost it has the advantage of eatehing and holding the snow and eheeking soil blowing during the winter and of arresting run-off.

When the lister is used in preparing land for winter wheat, the listing is done immediately after the harvest of the preeeding erop. The soil is worked down level, usually with a dise, in late summer or early fall and then seeded with an ordinary grain drill. Very little difference in average viclds between listing and plowing have been noted except at Hays (Kansas), where the advantage is in favor of listing. (Bul. 268-p. 22).

244. How and When to Plow.-The eomparative aver- 
age yields from fall and from spring plowing at each station for corn, spring wheat, oats, barley, milo and kafir have shown but small differences. As the land requires plowing for all annual erops exeept in those eases above noted, and as plowing is an expensive operation, it is a question of great eeonomic importanee as to how and

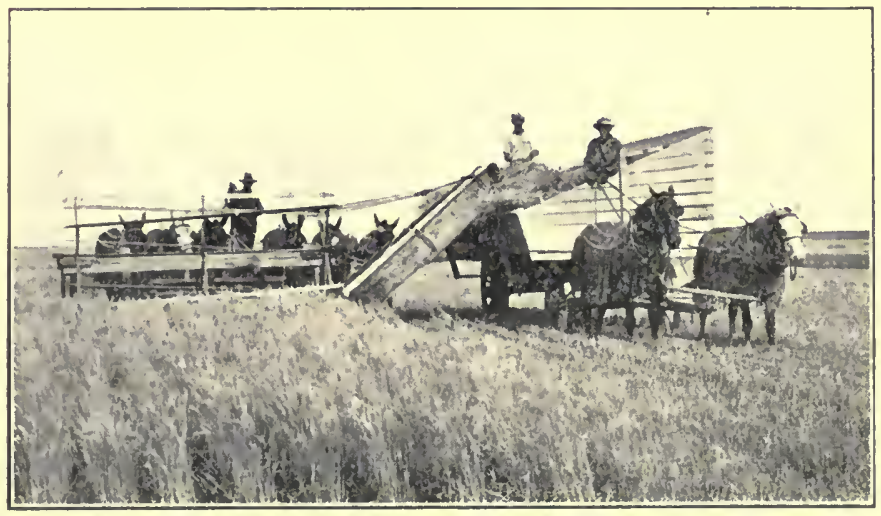

Fig. 98.-Harvesting Winter Wheat with a Header in Kansas.

when this plowing should be done. Much has been written upon this subject and many theories have been developed and advoeated, but the investigations condueted in the Great Plains by the Office of Dry Land Agrieulture seem to show eonelusively that no set rule ean safely be followed. The best practice seems to be to do a good elean-eut workmanlike job of plowing to a depth of from 4 to 8 inches when the soil is in proper eondition and the work ean be done to the hest advantage, taking into consideration the most eeonomieal distribution of labor throughout the year. (Bul. 268-p. 23).

245. The Purpose of Plowing.-It is mistaling or fail- 
ing to recognize the purpose of plowing that leads to the belief that its effieieney inereases with its depth, even though that depth be extended below all practical limits of eost and effort. Plowing does not inerease the waterholding eapacity of the soil, nor the area in which roots may develop, or from which the plants may obtain food. Plowing removes from the surfaee either green or dry material that may eneumber it, provides a surfaee in which planting implements may cover the seed, and removes or dielays the eompetition of weeds or plants other than those intended to grow, and in some eases, by loosening and roughening the immediate surface eheeks the run-off of rain water. All these objects are accomplished as well by plowing to ordinary depths as by subsoiling, dynamiting, or deep tilling by any other method. There is little basis, therefore, for the expectation of increased yields from these practices, and the results of these experiments show that they have been generally ineffeetive. (Journal of Agrieultural Research, Vol. XIV, No. 11p. 484).

The quite general popular belief in the effieieney of deep tillage as a means of overcoming drouth or of inereasing yields has little foundation in faet, but is based on miseoneeptions and laek of knowledge of the form and extent of the root systems of plants and of the behaviour and movement of water in the soil. (loc. cit.-p. 521).

245a. Green Manuring.-Green manuring has not usually given as high yields of spring wheat, winter wheat. oats or barley as has summer tillage. It has yielded but little if any higher than disked eorn ground with any of these crops. It is much more expensive even than summer tillage. There is not yet any apparent eumulative efferet of the addition of lummus to the soil, although it has 
been practised at some of the stations for twelve years. The evidence so far as to its practicability is negative.

246. Destruction of Weeds. - The destruetion of weeds is nearly always desirable, as under dry-farming conditions weeds are one of the most serious obstacles to successful erop production. When summer tillage is praetised on a bare fallow during the entire season, cultivation should be frequent and thorough enough to destroy all weeds before they attain suffieient size to transpire appreciable quantities of water or to reseed themselves. This tillage will also keep the surface in a condition suffieiently loose and open to allow the rain that falls to penctrate it. When the soil becomes well filled with water early in the season and additional rains can reasonably be expeeted, it may sometimes be desirable to allow the weeds to attain a larger growth and then plow them under in order to provide additional organie matter in the soil, but it must be borne in mind that this gain in organic matter is made at the expense of the soil moisture.

Our investigations show that summer tillage is, with the exeeption of green manuring, the most expensive and least profitable method under trial. Exceptions are to be noted in the case of kafir and milo at Dalhart, eorn at Scottsbuff, and winter wheat at North Platte and II untley.

The purpose of summer tillage is aceomplished by the prevention of vegetative growth rather than by the maintenance of a mulch. Numerous experiments made in connection with this work have furnished an abundance of evidence that when vegetative growth is restrained the loss of water from a mulched surface is practically the same as from an unmulehed one. 
The eheapest and most efficient methods of weed destruetion necessarily form a soil mulch. The results aeeruing from the prevention of weed growth have been very generally attributed to the muleh itself when the mulch is, in faet, only accidental.

Tillage for the purpose of destroying weeds after harvest is warranted only in those exceptional cases when sufficient water remains in the soil to start weed growth after harvest or when heavy rains come soon after. In such eases early fall plowing is the most effeetive method of destroying the weeds and thus saving the moisture that would be used by them if allowed to grow. The same object may be aecomplished by disking soon after the weeds have started. This method has the advantage of being more rapid than plowing, thus making it possible to eover more ground with the same number of teams and men. But as the land will have to be plowed before another crop is sown, the labor of disking is mostly lost, although the labor of plowing the disked land may be somewhat less than if it were not disked and a better job of plowing may sometimes be done on the disked land. The eost of early fall plowing or disking, when the weather is hot and the men and teams are needed for stacking, threshing, and hauling grain, is greater than later in the fall, when the weather is eooler and there is less other work for men and teams. All of these facts should be taken into eonsideration before going to the extra expense of tillage to kill weeds immediately after harvest.

Spring plowing or disking, as soon as the weed seeds - have germinated, is usually a profitable praetiee. Where small grain is to be sown, the sowing should be done soon after plowing; but where corn, potatoes, or the sorghums are to be grown there is often a period of several weeks 
between the time of the germination of the weed seeds and the time when the season is suffieiently advaneed to plant the erop. This period should be utilized as far as possible for the destruction of weeds before the erop is planted. Much labor in keeping the erop free from weeds during its growing period ean thus be saved. - Harrowing small grain for the destruetion of weeds after the grain is sown and until it has reached a height of 3 or 4 inches may sometimes be practised to advantage. Experimental evidence does not show it to be generally profitable. Harrowing corn and potatoes after planting and until the young plants have attained a height of 2 or 3 inches is quite generally practised to advantage.

It is absolutely essential for the most profitable growth of corn, potatoes, the sorghums, and, in fact, all the intertilled crops, that suffieient tillage be given to keep the growing crop free from weeds until the plants have attained such growth that they will be seriously injured by the cultivators or the horses. (Bul. 268-p. 24-25).

\section{The Application of the Capillary Theory to Dry} Farming Practices.-The capillary theory is undoubtedly responsible for more false reasoning about dry land agrieulture than any other one thing. It is a eonvenient theory to explain certain well-known phenomena such as the rise of oil in a lamp wiek, but it must be taken in its entirety. It will not do to eliminate the one most important factor in the theory and then expect it to work. This one factor is the presence of a constantly replenished supply of free-moving water at the base of the system. In other words, a permanent water table within a few feet of the surface of the soil, a condition that is never met under true dry land conditions. Therefore, any system of dry land farm practice that is dependent upon the as- 
sumption that there is a continuous upward movement of soil water by eapillarity of suffieient magnitude to materially affect erop growth will prove disappointing when put to the test of aetual ficld praetiee, as has been done in the extensive investigations eonducted during the past fourteen years in the Great Plains by the Office of Dry Land Agriculture.

A careful study of hundreds of thousands of soil moisture determinations fails to show any such movement. The soils of the semi-arid regions undoubtedly do lose large quantities of soil water, but this loss is undoubtedly due almest entirely to some one, or to a combination of two or more, of three factors, utilization by the grosing erop, transpiration from growing weeds, or loss from internal evaporation and eseape from the soil to the atmosphere in the form of water vapor. Only such methods of moisture eonservation as will prevent loss from these sourees are worth considering, so far as the water which has actually entered the soil is eoneerned. Excessive runoff may be retarded and the absorption of water by the surface soil may be facilitated to a limited extent by proper methods of surface tillage. But any method of tillage ealeulated to prevent capillary rise and surface evaporaticn of soil water in semi-arid regions will be useless exeept in so far as it stimulates the growth of erop plants, destroys weeds or retards their growth, or ehecks the escape of water vapor from cracks or other openings in the soil.

248. Farm Organization and Crop Rotations.-As forage erops of some kind ean profitably be grown at all stations, they must oceupy an important place in any system of farming adapted to the Great Plains. Sufficient live stoek must be kept to convert these erops into 
finished produets on the farm and sufficient forage must be prodireed and stored during the favorable seasons to earry the live stock throngh specially unfavorable seasons.

Good farming is an essential to suceess in the Great Plains area as elsewhere. Good farming means practicing the best method of producing the largest erops at the lowest relative cost of production and leaving the soil in the best condition for the production of subsequent erops. Good farming may involve methods either intensive or extensive, either expensive or inexpensive; and it must be practical and economical as well as seientifie and thorough in order to be good farming. It is just as poor farming to go to too much expense as it is to go to too little expense to aceomplish a given result. These investigations show that the largest net profits have usually been obtained from crops raised by eultural methods involving a low eost of production rather than from high yields obtained under methods involving a high eost of production. Lessening the cost of production without proportionately lessening yields should therefore be given first consideration. In other words, extensive rather than intensive systems, of farming should be followed.

Different types of soil and different combinations of chimatie conditions require different cultural methods and different combinations of erops to produce the most profitable results.

The personality of the farmer and his family; the size, loeation, soil and environment of the farm ; market facilities and prices; the available eapital, in cash, labor, or equipment, may any or all be determining factors in the problem of profitable dry farming in the Great Plains area. 
Dry farming in the Great Plains area, in common with all farming, to be suceessful must be systematized, and in order to aceomplish this, some definite rotation of crops should be established. In planning such a rotation, due consideration should be given to all the faetors here emumerated, as they apply to each partieular farm and farmer. With these considerations elearly in mind, it is believed that no intelligent farmer will experience any great diffieulty in adopting a system of erop rotation and farm organization that will be better adapted to his conditions than any that eould be proposed by anyone less familiar with these conditions than is the farmer himself. (Bul. 268-p. 27-28).

\section{DRY FARMING PRACTICES IN KANSAS}

By L. E. Call, Professor of Agronomy, Agriculturai College, Manhattan, Kansas.

The average ammual lainfall of Kansas varies from less than sixteen to over forty-five inehes. In the eastern twothirds of the state, it exeeds twenty-two inches while in the western third, it is less than this amount. 'The average anmul rainfall is ample for all crops in the eastern two-tlirds of the State, but irregular distribution and very rapid evaporation during the growing season often makes it neeessary to conserve moisture with eare if profitable crops are to be produced. It is only in the western thisd of Kansas that moisture is so deficient that it is neessary to use the bare summer fallow in the elopping system. In this section, fallowing is not necessary mole often than onee in three to five years, and even then ma! 
not be neessary if the fallow season should prove musually favorable.

249. The Place of Summer Tillage.-The sol'whum celops and winter wheat are the most dependable dry farming erops for Kansas. These crops must be grown in rotation for best results. It is advisable in western Kansas to summerfallow sol'ghum ground in changing from sorghum to wheat mless conditions are umsually favorable. In an unusually wet fall, wheat may be sown on disked sorghum ground, and in an unusually wet spring, barley may be sown on disked sorghum ground in the spring. At all other times, it is best to summerfallow sorghum ground for wheat.

The best method of preparing sorghim glound for wheat is to disk the ground in the spring after the first weeds start. This kills the first crop of weeds and starts other weed seeds germinating. The ground is then plowed before the second growth of werds becomes too large and in time to finish plowing before harvest. The fallow is usually plowed: in late May or early .June. It is left without work until after wheat harvest which oceurs in July. In Angust and early September, it is worked down and the wheat seeded in late September. Cale must be exerrised not to wolk the fallow ground mole than necessaly to kill weeds and to prepare a good seedbed for wheat. otherwise, the surface of the field may be left too smootl and the wheat injured by soil drifting during the wintere. Whon stubble gromul is summerfallowed, it is handled in the same mammere. It is the misual proctice to grow wheat at least three years after fallowing before changing the gromel to soreghmon. 'The first year the wheat is

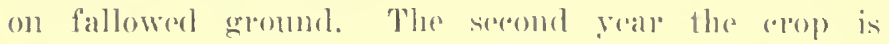
drilled in the stubble and the thirel season, the eromed is plowed after latrest and the erople seeded the same fall. 
The next year the field is changed to a sorghum crop. After growing sorghum from one to three years the land is fallowed and returned to wheat. Corn frequently replaces sorglum in this rotation, or corn may be planted

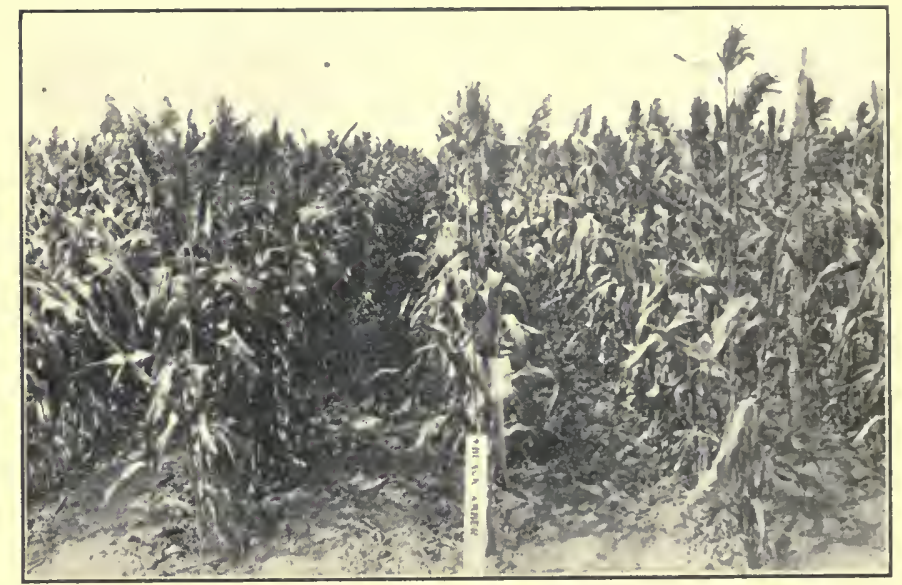

Fig. 99.-Black Amber Sorghum in Kansas.

This is one of the leading types of drought-resistant forage crops in the South.

after the sorghum erop in place of the fallow. It is only under the most favorable conditions that corn should be used in this way.

250. Kansas Dry Farm Crops.-The best dry farming crops in Kansas are of two distinct kinds. First, those that are able to withstand extremely hot summer weather and take advantage of moisture whenever rain may oecur and seeond, those that mature early enougl in the spring to escape the hot dry summer weather.

The sorghums are the best example of the first elass of crops. They have the ability to withstand high temper- 
atures and to remain in an mninjured condition for a long period of time without rain. There are varieties of sorghums adapted to many different uses. Kafir, milo, feterita and kaoliang are especially valued for the produetion of grain; the sweet sorghums sueh as blaek amber red amber, orange and sumae are very large growing, leafy plants and are especially valuable for fodder and silage; while Sudan grass is more grass-like in eharaeter and is espeeially valuable for hay and pasture. Kansas is fortunate in having this valuable sorghum family of erops so well adapted to the ciry farming seetions of the State.

251. Crops That Mature Early.-Winter wheat is the best example of those crops that mature early. It matures in late? ?une or early July and thus eseapes the hot summer months. The best winter wheat varieties are those that mature early and at the same time are winter liardy. Varieties of the Turkey Red type have given best results. Jf these, Kanred, a variety developed at the Kansas lixper:ment Station, is the best. It matures somewhat earlier than other varieties of Turkey, is more winter hardy, less susceptible to most diseases and is somewhat more productive. Spring wheat always matures later than winter wheat and eonsequently is more often injured by hot weather. It cannot be sueeessfully grown in Kansas exeept in the northwestern part where the elevation is higher and the summers eooler than in the rest of the State. Barley is the best dry land spring grain for Kansas. It matures earlier than oats and consequently produees more grain. When oats are sown only very early varieties sueh as Burt and Red Texas shonld be used.

252. The Amount of Seed to Sow.-Where moisture 
is limited it is not advisable to sow grain too thick, otherwise the supply of moisture may be exhausted hefore the erop is matured. The quantity to sow will depend upon the eharacter of the soil, and the time of seeding. On well prepared summerfallowed ground, one-half bushel of winter wheat is sufficient seed to sow in western Kansas. On ground less well prepared, a bushel of seed is often necessary. When wheat is sown very late in the season, more seed should be used for it will tiller less and therefore, should be sown thicker.

\section{DRY FARMING IN NEBRASKA}

By W. W. Burr, Professor of Agronomy, Agricultural Explamiatit Station, Lincol, NeB.

A large portion of the cultivated land west of the hundredth meridian in Nebraska is under what is commonly ealled dry farming. The conditions that determine dry farming are a dry subsoil and a limited rainfall. Within the area mentioned in western Nebraska are sub-irrigated areas where sheet water comes elose to the surfaee, and there we could not say that dry faming is practised. Obviously, where water is applied by irrigation, it is not dry farming.

The early experiences of farmers in wostern Nebraska were far from satisfactory, and many failures resulted. There were several causes for this, aside from the uneertainty of the weather,- - lack of experience in dry regions, poorly adapted crops, and lack of working capital probably heing the main ones. 'The comditions have changed considerably in the last 15 years. Ont of the experiences of the famers have crystallized some very sound and 
definite information. To this have been added results of agrieultural investigations, all of whieh has brought about a mueh better understanding of the situation. More adapted crops, more suitable machinery, and, what is per haps even more important, the farmers have aceumulated

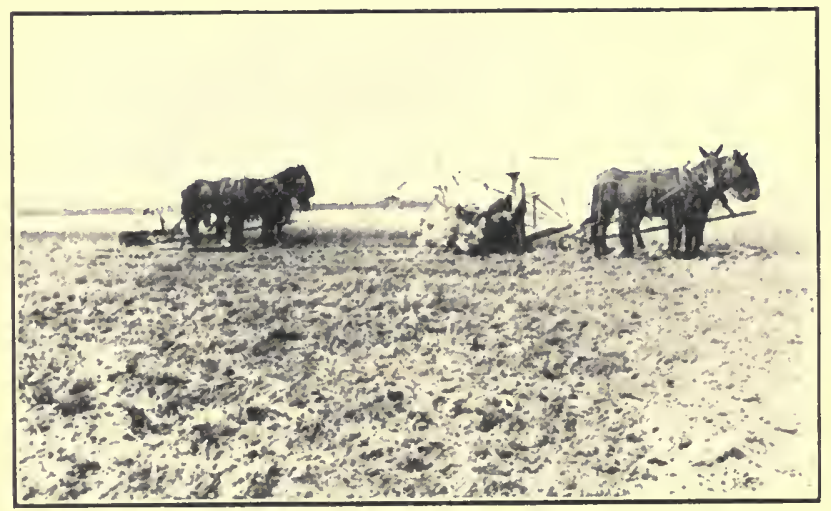

Fig. 100.-Disking Behind the Binder to Conserve Moisture in Nebraska.

a working eapital or a credit, sufficient to tide them over adverse seasons.

The dry farming area of Nebraska eontains many types of soil. Considerable areas are so sandy as to be unfitted for grain production, and the farming operations are confined largely to supplementing the native feed for live stock. In other areas the soil is heavier. It is fertile, and with sufficient moisture responds abmurlantly to grain eropping. No very distinct methods are employed in dry farming. The amount and kind of tillage is mally determined by the seasonal eonditions and the avalable supply of man and team labor.

253. Summer Tillage is not extensively practised in 
Nebraska. It is oecasionally practised on limited areas in preparation for winter wheat or in preparation for a grass erop or alfalfa. The farmers have found that wheat is quite as certain after eorn as it is after summer tillage, though the yield may be somewhat less. The cultivation of the eorn costs praetically no more than the summer tillage, and by growing the corn they obtain a considerable amount of roughage and usually a grain erop. The roughage is an important factor, since in almost all of our dry farming sections considerable live stock is earried. Where summer tillage is practised, the land is usually left uncultivated until after corn planting, when it is plowed; and after plowing, suffieient cultivation is given with a dise or harrow to keep down weed growth.

254. Crop Rotation.-There is no véry definite system of rotation in the dry farming area. The most nearly definite is corn and winter wheat alternating. The winter wheat is usually drilled with a one-horse drill into the standing eorn. Later the corn is harvested, usually by husking from the standing stalks and then turning the stock in to get what rough feed they ean. Where the corn has been kept fairly clean, this is a very satisfactory way of growing winter wheat. The wheat goes into a firm seed bed and has the stalks and stubble to catch snow and serve as a protection from blowing during the winter. Ordinarily the wheat stubble is prepared for corn simply by disking it early in the spring and then putting in the eorn with the lister.

255. Crop Adaptation.-This is a very important factor in the development of any section. Obviously no amount or kind of tillage will make profitable the production of a poorly adapted crop. All of the ordinary grain crops 
suitable to this section are grown in the western part of our State. Winter wheat is tending to replace spring wheat. Turkey Red winter wheat is most conmonly grown and is well adapted. Both common and Macaroni spring wheats are grown, and no one variety has proved markedly superior to several others. In most of the area the early type of oats has proved superior to the later types. Kherson is most commonly grown. Ordinary six-rowed barley has proved superior to any of the two- or four-rowed variety. The eomparatively small types of corn are grown, the size varying with the seetion and the probable amount of available water. Under the most extreme conditions a rather flinty type of corn with a 5 or 6-inch ear is grown, while under more favorable conditions they grow an 8 to 10-inch ear decidedly more dent in type. Alfalfa grows abundantly in the bottom lands where sheet water is within reach of the deep roots. It is grown, but with less eertainty of produetion, on the urlands. For seed purposes it is sometimes grown in rows. Millets and Sudan grass are successfully grown throughout the entire area. Sorghum for forage is probably the predominant annual forage erop. Grain sorghums are not extensively grown.

256. Cultural Practices.-Small grain is almost universally planted with a grain drill in preference to broadcast seeding. Corn is usually planted with a lister. Early planting is advisable for all small grain erops, as it tends to get them ahead of the usual dry, hot weather of midsummer. Corn is planted early in the frost-free period.

The usual rates of seeding are muel less than under more humid conditions. The following are the eommon rates per aere: Winter wheat, 40 to 50 pounds; spring 
wheat, 4 peeks; oats, 6 pecks; barley, 6 pecks; eorn, one stalk to 18 to 24 inches in the row.

Harrowing small grain is not extrusively practised. On the average it has not proved beneficial. Lucler certain conditions. where ground craeks or where there are many young weeds that may be killed, harrowing might be advisable. 'The harrow is often used to break down standing cornstalks where grain has been sown in the corn.

Deep plowing, or in faet stirring the soil in any manner to a greater depth than ordinary 6- to 8-inch plowing. nas not given avejage increased yields nor shown any particular advantage in overeoming drought. It has greatly increased the labor cost and lessened the aereage that a man with a given equipment ean handle. After plowing. the furrow slice is usually worked down with a dise or harrow. The subsurface packer is not in general use but may have an important place, especially where small seeded cops such as grass or alfalfa are to be sown. Getting the soil firm is an important factor, since the loose soil will dry out much more fuickly than the more firmly packed soil.

257. The Farming Unit.-In the dry farming seetion the farming unit is comparatively large. Intensive enltivation is not generally practisod. Broadly speaking. elimatic conditions are more important than tillage methods in dotermining yields. Naturally when the differences of yield that come from climatic canses are greater than differences due to other factors, cost of production becomes the most important factor and the system of farming tends to beeome inereasingly extensive.

258. Live Stock.-In order to equalize ineome, live stock is almost essential to farming under our dry lank conditions. Where striet grain farming is followed, a 
crop failure is apt to be very serious: bit where both grain and live stock are raised, there is the chance, if the necessity arises, of selling oft some of the live stock in order to get through the period of stress. Animals are also important in that they furnish a profitable market for the roughage produced on the farm. Without stock, this roughage would have little value and probably would be wasted.

259. The Possibilities for Dry Farming.-Even under the climatic limitations, the possibilities for dry farming are good for the man who will work in aecord with nature. He needs a reasonable amount of eapital and a clear understanding of conditions. He should not allow himself to be hampered ly false hopes and theories, nor try to farm by hard and fast rules. Under the erratic climatic conditions of that section, any system of farming to be suceessful must be sufficiently elastic to meet conditions as they arise. By studying the conditions as they exist on his own farm and earefully considering the various factors that influence erop production, he can determine the kind and amount of labor that should be expended. By doing each operation in the most advantageons way and as nearly as possible at the right time, the lahor reduired can be materially decreased, more land gotten over with a given amomnt of expipment, and the cost of production lowered.

\section{DRY FARMINO PRACTHCES IN SOLTHI DAKOTA}

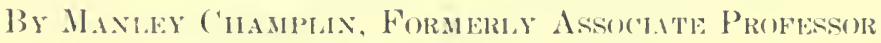
of Agronomy, Brooktsgs. S. D.

The average rainfall in South Dakota valies from 25 inches in the sontheast to about 14 or 15 inches in the 
northwest section. Most of the rain comes during the spring and summer months. There is usually a light snow-fall and eomparatively little rain in the autumu. The months of April, May and June are generally well provided with moisture and occasionally good rains occur in July and August, but there are short periods of drouth

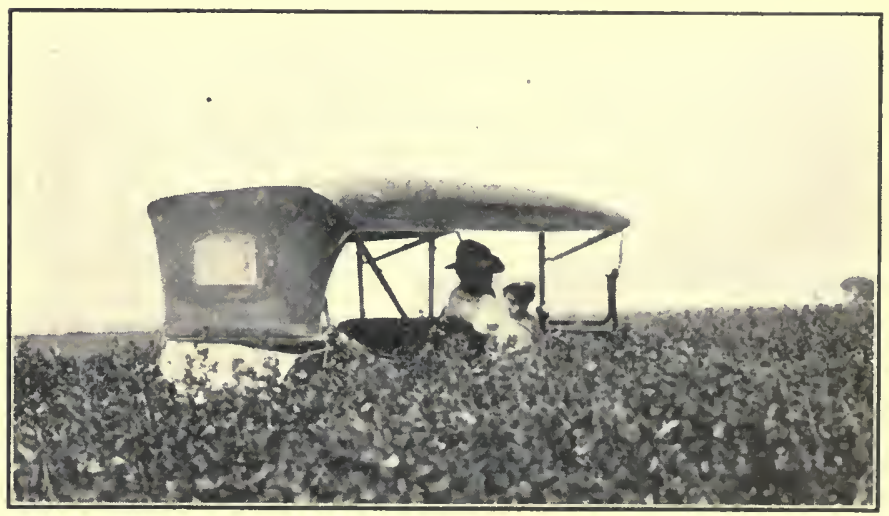

Fig. 101.-Sweet Clover.

A crop that is coming into popular use in parts of Nebraska and South Dakota.

in some parts of the state nearly every season and suecessful farming or erop produetion depends to a very great extent upon the suceess which one has in overcoming these short periods of drouth. There are oceasional seasons such as the year 1911 when eertain crops are failures in spite of good tillage and erop rotation methods, but there has not been any season since the State was settled that has not been favorable to some crops. It therefore is exeellent poliey to diversify as much as is practicable in older to aroid total loss in any one season. 
260. Summerfallowing.--Summerfallowing is praetised very little. Snecessful crops are frequently produced on summerfallow, but on account of the loss of the ineome from the land for a season ineident to this praetice, it has never beeome a common one in the state. When summerfallowing is practised the land is plowed 5 or 6 inehes deep in June, disked three or four times during the summer to keep the weeds down and usually sown to winter rye during the latter part of August. This praetice gives good results and eould be more generally adopted in the western two-thirds of the state.

261. Crop Rotation.-Crop rotation is a very important factor, not only in insuring safe erop production, but also in increasing the yield and improving the quality of the erops. Fortunately, it is possible for the farmer here to rotate his erops to the best advantage of the land and at the same time produce erops that are profitable. Among the cultivated erops corn is easily first. In fact it is the most important eereal erop of the state. Potatoes, amber sorghum, navy beans and soy beans may also be grown as eultivated erops. Oats, barley, spring wheat, emmer, spring rye and winter rye as well as proso and millet furnish wide choice among the small grain erops. Sweet elover is the leading biennial legume. It is hardy so far as we know in all parts of the state and it is easier to secure a stand of sweet elover than any of the other small seeded legume erops. Red elover can be grown in the southeastern and eastern seetions, but it is very difficult to obtain a stand in the drier parts of the state with this kind of elover. Canadian field peas and oats are sometimes grown together as hog pastures or as a temporary lay crop. Soy beans are oeeasionally mixed with eorn for silage. Alfalfa suceeds in nearly all parts 
of the state and may be used as a permanent meadow or may be treated as if it were a short-lived crop and used in the rotation. Experiments eonducted at the State Agrieultural College experiment farms in various parts of the state indicate that a three-year rotation of eorn, small grain and sweet clover is very satisfaetory. 'This rotation is easy to take care of and is satisfaetory from the economic or business standpoint. It is also a good rotation for maintaining the soil in good condition. It is handled about as follows: the land is divided into three parts approximately equal, the first field is plowed 6 or 8 inehes deep in the fall. In the spring this field is harrowed to break up the lumps and level the ground. About the first of May or a little later, it is double disked to further pulverize the seed bed and kill weeds. It is then harrowed again and planted to corn, potatoes or whatever cultivated erop may be desired. This crop receives thorough eultivation, usually from three to five cultivations during the season to keep it as free from weeds as possible. The following year this land is double disked and dragged in the spring without plowing and is sown to an early maturing variety of grain with $10 \mathrm{or} 15$ pounds of sweet elover per acre. If alfalfa is preferred. it may be substituted for the sweet clover. 'The grain crop is harvested leaving the stubble to proteet the elover or alfalfa plants during the second winter. The third year this field will be produeing sweet clover or alfalfa. A crop of sweet clover hay will be ready to cut by the 10th to the 15th of .June. A seed erop will be ready late in August or early in September. If in alfalfa the (rop) will be cut from one to three times according to the abundanee of moisture during the season. It is not best to cut it after the first of Septembor as the alfalfa is more 
likely to winter in good shape with a liberal aftermath. After the rotation is in full swing there will be one field in corn or other cultivated crop, one field in small grain and one field in legume, either sweet clover or alfalfa. Variations in this plan of rotation are casily made and work out very nicely. In fact the rotation is so adaptahle that it can be made to fit almost any requirement. It can be changed to a four-course rotation by growing two crops of corn in sucession, followed by the grain and sweet elover or to a five-eourse rotation by growing eorn in one field for silage, following it with winter rye, following the rye with corn for grain and the corn in turn with spring grain and sweet elover or alfalfa. The principle involved in sucessful crop rotation in South Dakota consists in providing for a cultivated erop preceding the grain crop in order to conserve moisture and render the seed bed firm and in good tilth for the seeding of the grain and the hay erop. Yields in favorable seasons are often doubled by this practice and in unfavorable seasons yields are seeured that are very satisfactory while the erop on land put into grain continuously may prove a total failure.

262. Drought-Resistant Crops.-In the arrly yearss of South Dakota's development great difficulty was experieneed because the erops which the settlers attempted to grow were not of the proper variety. 'Throngh the efforts of the United States Department of Agriculture and the State College of $\Lambda$ griculture crops have been introduced from south-eentral Russia and other eountries where eonditions are somewhat similar and thoronghly tested in comparison with varieties from other somrees, until the ones which were best for South Dakota conditions were determined. After introduction and testing, these var- 
ieties have been distributed through the efforts of the South Dakota Experiment Association until at the present time nearly all of the crops grown in the state are of adapted varieties. Odessa, S.D. 182 barley can be grown successfully throughout the state. Manchuria, Minnesota 105 is well adapted to the eastern section. Among the oat varieties, Sixty Day S.D. 165 and its selections have proved best and are generally grown. Two medium late varieties are fairly popular, namely, the Swedish Seleet S.D. 112 and the Silvermine. Durum wheat is represented by Kubanka S.D. 75 and a pedigreed varicty seleeted from the Kubanka, Aeme S.D. 284. Common spring wheat is almost exelusively Marquis or Preston proeured from Canada. Swedish S.D. 348 and Dean S.D 177 and a seleetion from Dean, the Advance S.D. 1030 are hardy varieties of winter rye. Grimm S.D. 162 and common alfalfa grown in South. Dakota for a long time are the most eommonly grown and best adapted varieties of alfalfa. There is some Turkestan grown, but its popularity has not inereased with that of the Grimm and the South Dakota Common. Cossack, a new variety, is proving hardy and becoming popular in some localities. White Spring emmer is the only variety of emmer grown. Tambov S.D. 80 is the best proso and Kursk S.D. 79 or a selection from Kursk known as Shelley S.D. 348 are the best adapted millets. Corn varieties have been introdueed and developed by eorn growers in nearly every section of the state. In the southeastern section A. J. Wimple has developed the Wimple's Yellow Dent, in the northwestern seetion the late Logan Slaughter has earried on the work of seleeting and increasing the large strain of Squaw eorn known as Slaughter's Squaw eorn. The Northwestern Dent variety has given a good aceount 
of itself in the entire northern section. In the eentral seetion the Minnesota 13 Yellow Dent and the Dakota White Dent are quite generally grown.

\section{Conclusions}

As a result of the introduction of hardy adapted erops and the increasing praetice of erop rotation and diversified farming in eonection with the production of registered and high grade live stock, the agriculture of South Dakota is rapidly getting upon a permanent basis and the prosperity of the state which depends entirely upon its agrieulture has constantly increased. The state is growing rapidly in population. If a proper proportion of this population interests itself in farming so that the farm labor problem gradually becomes less aeute, there is every reason to hope for a eontinuation of this prosperity, due to inereased farm production which ean be attained by the better farm practice that will be possible with more help available.

In making these statements, we have tried to make it clear that suceessful crop production in this state does not depend upon any one minor praetice, such as harrowing the growing erop, harrowing fall plowing, exeessively deep plowing, packing or sub-soiling, but depends upon a continuation and eombination of all good farm praetices in connection with the use of good erop rotations and good seed of adapted varieties with requisite attention given to keeping up the fertility of the soil and improving its physical condition by the addition of balnyard manure and the inelusion of elovers, alfalfas and similar erops in the rotation system. 


\section{DRY FARMING PRACTICE IN NOR'TI DAKO'TA}

\section{BY W. R. PORTER, SUPERINTENDFNT OF DFMONSTR.ITION ' FARMs for North Dakota.}

The term dry farming is usually consiblered to include those types of farming that are practised in areas having less than twenty inches of ammal rainfall. If this definition is eorreet parts of the Red River Valley in North Dakota and all the region west of the Red River Valley eome within the dry farming area.

The ability of the soil to hold moisture is probably a more important factor in the success or failure of a farmer than the amount of rainfall annually reeeived. Thirty inehes of rainfall on a loam soil with a sand or gravel subsoil will probably not be as effective in producing erops as fifteen inches of rain on a loam soil having a elay subscil. 'The plaee for summer tillage under North Dakota conditions is where the farms are too big to use all the corn or handle all the potatoes that might be prodneed if these erops were grown or where peremuial weeds such as the sow thistle, and quack grass, have got a hold on the land. Summer tillage is the only method we have of eombating these weeds.

263. Summer Tillage.-Land which is to be summer tilled, particularly if infested with the above named weeds, should be plowed about 3 inches cleop the lattel part of October. This has two effeets, it saves moisture and exposes the weed roots to more or less winter killing. The latter part of May or eary in . Inue this land should be plowed five to six inches deep and after that it should be cultivated at forpuent intervals with the Spring 'looth D)uck Foot Cultivator. 
The bare fallow has no place in a good system of erop rotation in North Dakota. The climate of North Dakota is a little too cold to grow sorghum. Corn, however, does well and as a feed crop it should always be used in preference to summer tillage as it gives a good return in feed and the land is in just as good shape to produce a small grain crop the following year.

Potatoes are a profitable crop and they leave the land in exeellent condition for small grains. One acre of potatoes requires approximately as much labor as five acres of small grain and will probably give more than five times the return per acre.

264. Stubble Land.-In the heavy soil areas stubble land should be plowed as soon after harvest as possible. This land should be packed with a subsurface packer or with a dise run straight, the day it is plowed. The next spring sueh land may either be diseed or harrowed or both in order to make a compact fine seed bed. The important thing is to have the seed bed eompact with a rather coarse mulch on the surface and not too smooth. Light soils should be left for spring plowing. They should be subsurface packed and seeded the day they are plowed, if possible. Only rarely should the harrow be used on lighter, sandy soils in the spring.

265. Grass Land.-One of the best ways of utilizing grass land is to break in the spring, pack down level with a weighted dise or roller and dise until a fine muleh is on the surface and seed to flax. The other method is to break in the summer time and double-dise carly the next spring, harrow until the seed bed is fine and seed to wheat.

266. Rotations.-Profitable rotations requirc small grains, legumes and eultirated crops. 'The simplest pro- 
fitable rotation of this character for North Dakota is potatoes or eorn, seeded to wheat without plowing and with the wheat sow sweet clover. This would be a three-year rotation eonsisting of wheat, sweet elover, and eorn or potatoes. A longer and more practical rotation would be to have a field in each of eorn, wheat, sweet clover, potatoes, wheat, oats or barley, flax and one field seeded permanently to alfalfa.

In the dry region it is very important to maintain the organie matter of the soil as this eonstituent has great ability to hold moisture and prevent the soil from drifting. Legumes are neeessary to keep up the nitrogen eontent of the soil and at the same time they furnish the best kind of feed for live stoek which in turn helps to keep up the fertility of the soil and at the same time give a permanent income.

267. The Best Crops.-The best varieties of wheat for the dry region are Marquis and the two Durums, Aeme and Kubanka. Early varieties of oats should be used, such as the "Sixty-day", Early Mountain, and Swedish Seleet. Of the mid-season varieties the Siberian White and the Lincoln are the best. One of the wilt-resistant varieties of flax should be used such as N.D. 114, 52 or 155. The two-rowed barleys, such as Swan Neck and Hamuschen are the most productive. The yellow variety of sweet clover (Melilotus officinalis) is probably a little superior to the white (Melilotus alba) varioty. The Grimm is the only variety of alfalfa hardy chough for our conditions. Brome grass is the hardiest and most palatable grass. Westem rye grass is also very good. Sunflowers may be used as an intertilled (rop or as a substitute for corn as a silage crop).

268. The Rate of Seeding.-In the drior parts the mate 
of seeding should always be less than in lumid sections. In western North Dakota three-fourths of a bushel of wheat is sufficient on most farms. One and one-fourth bushels of oats and barley are plenty to seed.

269. Weeds are a great muisance throughout the dry farming section. Wild oats is probably the worst of our annual weeds. The seed will not grow in the fall but readily grows and matures in fields of small grain. A good system of erop rotation is necessary to keep this weed in control. The Russian thistle is present everywhere in the dry regions. In the wetter years it eauses but little harm but in the dry seasons it often grows up and smothers erops and makes their harvesting difficult. It may be used for hay or silage and if fed with other feeds it has been found fairly nutritious. A good system of crop rotation is also very benefieial in holding this weed in eleck.

270. Soil Drifting.- This sometimes causes the total destruction of erops. It is usually the result of the eontinuons growing of small grains, particularly if alternated with summerfallow or summer tillage. Prevention of soil drifting is preferable to curing it after it starts. The growing of grass crops in the rotation and the returu of all the organic matter sueh as straw to the soil, in the form of manure and the leaving of the surface soil rough will prevent soil drifting. Where the soil is light and so deficient in orcanic matter that it drifts badly it should be spring plowed only. Strips of straw should he seattered over it at intervals and the surface of the soil should be left rough and the land seeded the same day it is plowed.

Great care must be used in harrowing the crowing erop. 'This practice usually makes the crope somewhat 
later but it is effeetive in thinning out weeds, particularly those starting from small seeds such as mustard, buckwheat and pig weed. Harrowing should only be done with a light harrow on a firm soil after the erop is 5 or 6 inches high and on a warm sunshiny day. Heavy soils should be harrowed inmediately following the plow as this breaks up all the lumps and leaves a good surfacc mulch.

Packing is best aceomplished by using a dise set straight and going over the soil the day the land is plowed. The subsurface packer is also a good implement to use. Early after harvest disking probably is benefieial but it eomes at a time when the labor supply on the farm is in great demand for other necessary operations. Plowing deeper than 6 inches probably does not pay.

A farmer in the dry region should aim to get one-half of his income from live stock and live stock products. In the good years when he has an abundance of feed and straw, this should be earried over for the years of exeessive drouth. This together with what he can produce by good cultivation will assure him a steady income even through the most adverse seasons.

\section{DRY FARMING IN MONTANA}

By Alfred Atrinson, President Montana State College of Agriculture. (Formerly Professor of Agronomy).

Dry farming in Montana has been practised in sections of the state for a long period of years and is now thoroughly established. In the light of the experiences gained, the following stand out as the essential requisites which must be met if suceess is to be gained. 
271. Limited Supply of Moisture.-The eonditions for crop growth in the dry farm sections are most favorable with one exeeption. The soils are rich in plant food and the temperatures are favorable, but the supply of moisture is below the amount eommonly considered necessary. A system must, therefore, be adjusted to make the most efficient use of the moisture present. The chief ways of doing this are conserving moisture by careful tillage and the sclection of crops and the use of crop management methods that make the most eeonomieal use of moisture.

The saving of a maximum amount of valuable moisture is important to insure plant growth and also to make available the plant food in the soil. Continuous eropping results in low yields, chiefly because the valuable plant food in the soil beeomes uscd up. It is, therefore, necessary to make light moisture demand occasionally in the summer time in order that there may be heat, air and moisture present to bring the plant food into condition to be used by growing erops. The eommon method of establishing these conditions is by means of the summerfallow. In many sections, the tendency has been to substitute cultivated erops, sueh as corn or sunflowers, in place of the fallow. Where careful tillage is followed, moisture may be eonserved about as effeetively in a corn field as in a bare fallow and the feed produeed is most valuable in maintaining and adding to the number of live stock kept. It, therefore, seems essential that the dry farm field should be fallowed or planted to an intertilled crop not less than two years in five.

272. Early Maturing Crops.-In many dry farm sections of the West, the heavy precipitation falls between the first of $\Lambda$ pril and the 15 th of July. Under this eondition, it seems wise to plant crops that will make most 
of their growth during this period and be far enough along to fill in good shape before the hot, dry weathey starts in. Fall-sown wheat eommonly matures early and the heads fill before the dry period. Such early maturing strains as the Marquis Wheat, the Sixty-Day Oats and the White Hulless Barley are rapidly growing spring strains and they should be used on the dry farm. 'The late maturing strains, which produee the heavy straw returns, commonly exhaust the moisture in the soil before the grains are developed and this means a light grain return.

273. Light Seeding.-To economize the moisture present, light seeding should be practised. Under humid or irrigated eonditions, two bushels of seed is a fair rate of planting, while on the dry farms, from three to four pecks has given better returns. The light seeding limits the straw produetion and carries more moisture over for the maturing of the grain.

The dry farmer, who would play safe, must have more than one souree of ineome. Where land returns on the year's effort are all tied up in one grain crop, a dry season has a very disastrous effect. Every dry farm should carry some live stock, so that the risk of the dry period is not so great. Even if forage may not be produced during the dry spell, the live stock may be sold to some exterit and this will insure some income. Com or Mammoth Russian sunflowers, if carefully cultivated, give large silage returns, and with the winter and also the summer silo, the pasture shortage may be supplemented. Many successful dry farmers are filling one or more silos and carrying them over to feed during the following summer. This, as a pasture supplement, is most valuable. 
Dry farming is not gambling on a wet seasom. It is so eonducting the operations of the farm that there is fair prospect of returns every year.

\section{DRY FARMING PRACTICES IN THE RED RIVER VALLEY}

By T. J. Hirrison, Professor of Field Husbandry, Manitoba Agricultural College, Winnipeg.

The Province of Manitoba may be divided into three agronomic zones, i.e., Eastern, Southwestern and Northwestern. It is not possible at this time to state definitely the boundaries of these districts because no detailed climatie and soil survey has been made. The Eastern section or the Red River Valley may, however, be deseribed as that portion occupying the basin of the old glacial lake Agassiz. It is approximately that part of the Province which lies between the 96th and 98th meridians, and south of the 51st degree of latitude. The Southwestern and Northwestern sections are west of the 98th meridian and are separated approximately by the 50 th degree of latitude.

The fundamental differences in farming methods in these distriets may be summarized as follows:--

Southuestern: Except for the lack of moisture the climate in this distriet is favorable to the production of any of the small grain crops. The average annual preeipitation is only about 15 inches. 'The farm practires are, therefore, adapted to the eonservation of moist ure.

Northuestern: In this portion of the provines there are many variations in climate due to the mountains and lakes. The annmal precipitation is ahout 18 inclees. This with the cool climate and low evaporation is usually 
sufficient moisture to produce good crops. The early fall frosts influence the type of farming more than moisture conservation; therefore, the growing of early ripening varieties and the use of methods of soil management that will induce early maturity are the general farm practices.

Eastern or Red River Valley: The elimate of this district is more favorable to crop production than that of any other portion of the Provinee. The annual precipitation is about 20 inches. A large amount of this moisture eomes during the growing season and if not wasted is more than suffieient to produee maximum erops. With the standard varieties now in use on most farms there is practieally no danger from fall frosts. The methods of farming are based as much upon the control of such factors as weeds, plant diseases and inseets as they are upon the conservation of moisture. Fortunately, however, methods that control weeds and insects are usually the same as methods that conserve moisture.

274. The Place of the Bare Summerfallow in the Red River Valley.-Since the pioneer days when grain growing became prevalent the summerfallow has been the popular method of preparing stubble land for erop. The purpose of summerfallow is to prepare, during the slack season, a large aereage of land for crop and to conserve moisture. Before the advent of the perennial sow thistle the summerfallow was introdneed into the rotation every fourth year. Since the eontrol of this weed has become important it is now necessary in most instances to fallow every third year. Where this practice is followed profitable erops are ensured.

275. Methods of Fallowing.-The methods of fallowing are determined quite as much by weeds and other factors 
as by the need of moisture. There are three methods praetised although eaeh has many modifications under different conditions.

1st. Using eultivator only.

2nd. Plowing in the fall and cultivating the following season.

3rd. Plowing in the spring and eultivating the balance of the season.

In the first method eultivation is done by the use of the stiff-shank wide duck-foot eultivator. From five to eight eultivations are required during the season to eradicate perennial weeds. The work is started the last of May or the beginning of June and is repeated as frequently as neeessary to keep the land black until freezeup. The first stroke is neeessarily shallow but the depth is inereased each time until the final cultivation is five or six inches deep. This ensures the shares cleaning and thoroughly cutting off the roots of the perennial weeds.

The second method eonsists of plowing the land five inches deep in the fall, and in the following year cultivating with a duck-foot eultivator. Six eultivations are usually neeessary to eontrol the weeds.

The third method with some modifieations is the one that is in general use throughout the district. The land is plowed in June about six inches deep, and is eultivated three to six times afterwards to keep down the weeds. This method is often improved upon by either skim plowing or disking in the previous fall as soon as the crop is off the ground. This practice induees the germination of the annual weed seeds in the fall and early spring. For fields infested with will oats this nethod is to be commended. 
276. Substitutes for Summerfallow.-Intertilled crops, such as corn, sunflowers and roots, can be grown in the Red River Valley for fodder every year with a fair degree of sueess. They leave the soil in a better condition for the sueceeding erop of wheat than summerfallow. The wheat erop has shorter straw and is, therefore, less subject to rust. Sow thistle eamnot be suceessfully controlled by intertilling and the average farmer cannot utilize the erop from 80 to 100 acres of corn, sunflower or roots. While this method may be profitably practised on a limited aereage, it will never fully displace summerfallowing as long as the present system of grain farming is practised.

277. Preparation of Stubble Land for Crop.-In preparing stubble land for crop it is eoneeded in the Red River Valley that fall plowing is neeessary. It requires the mellowing effeet of frost and moisture to put the heavy clay soil in condition for spring seeding. Spring plowing leaves the land so hard and rough that a seed bed cannot be made; so if the land has not been plowed in the fall, enltivation in the spring will give better results than plowing. This method of preparing stubble land for erop without the use of the plow will give fair results if the land is clean, but as the average farm contains several kinds of noxious weeds this method eamot be reeommended.

278. Preparation of Grass Land for Crop.--In the preparation of grass land for erop the best results are obtained by breaking two or three inches deep in June or even later and back-setting five inches deep in September. After the land is backset it should be packed and disked sufficient to keep down the weeds. Although 
this means the land is idle for the first year the succeeding erops will more than compensate for the loss.

279. Rotations.-The question of the most profitable lotation is one that has not been conclusively answered, but is one that is now under elose observation by many practical farmers and by the experiment stations. From the information on hand the following would seem to be the most profitable where straight grain growing is followed :-

1st Year-Summerfallow.

2nd Year-Wheat.

3rd Year-Oats and barley.

Where mixed farming is followed the following rotation has given good results and with modifications to suit the needs of individual farmers is being adopted :-

1st Year-Fallow, corn, sunflowers and roots.

and Year-Wheat seeded down to grass.

3rd Year-Hay.

4th Year-Pasture until after having, then break and backset.

5th Year-Wheat.

6th car-Oats and barley.

280. Importance of Organic Matter in Soil.-The maintenance of organic matter in the soil is essential to keep it friable and prevent baking. After a heary rain the fihre-depleted soil bakes and cracks and much moisture is lost. In this district, with the exeeption of some of the lighter soils here and there, soil-drifting is not a problem. Within the last few years farmers throughout the valley have been making more use of farmyard manure and grass and clever crops for the purpose of maintaining the soil filbre and returning some plant foot to the obler soils. 
281. Crops.-In this distriet, wheat, oats, barley, rye, flax, grass, clover, corn and sunflower's are the crops that may be eonsidered to give the best results.

Wheat: This crop has been the main souree of wealth in this distriet in the past. It will also eontinue to be the prineipal eash erop in the future unless the ravages

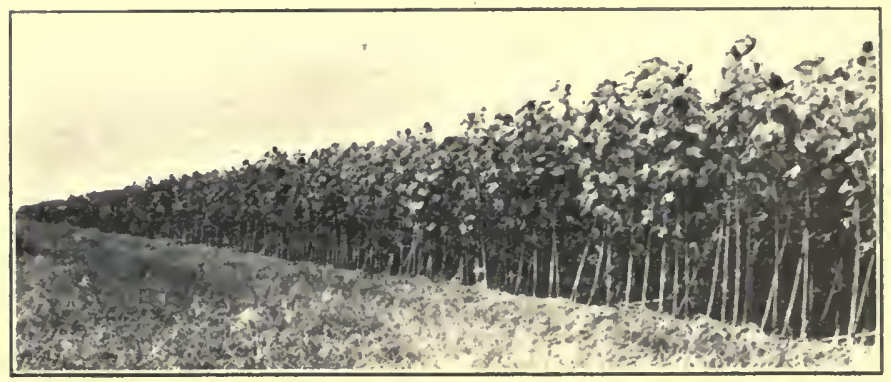

Fig. 102.-Sunflowers for Silage, Agricultural College, Winnipeg.

of rust make its produetion unprofitable. At the present time $95 \%$ of the wheat grown is of the Marquis variety. The remainder is made up of Red Fife and other less-known strains, such as Red Bobs and Kitehener. Durum Wheat, of which Kubanka is the chief variety, is also being grown. The Red Fife is later maturing than the Marquis, and, therefore, is more sub. jeet to rust. The Red Bobs is somewhat earlier but does not yield nearly so well. The Kitehener matures about the same time as Marquis but on the heavy elay soils gives a poorer yield. The Durum wheats are of more recent introduetion. If a ready market ean be found for this type and if they prove to be rust-resistant they may beeome more popular.

Oats: This erop does not thrive so well in this district 
as in the Northwestern. For that reason it is not considered one of the important eash erops. It is, however, largely grown for feed purposes; part of the erop is threshed and part used for eured fodder in the sheaf. Less attention has been paid to the varieties of this crop, and in nearly every municipality there will be found as many as ten to fifteen different sorts. The results at the experiment station, however, indieate that the three best varieties are Banner, Gold Rain and Victory.

Barley: The soil of the Red River Valley seems well adapted for the production of this erop. This, eoupled with the fact, that it can be used for weed eontrol, beeause of its early maturing habit, makes it one of the eash erops that is receiving more and more attention each year. Its main use, however, as yet is for hog and eattle feed. The three best varieties are O. A. C. 21, Manchurian and Mensury.

Flax: Where conditions are favorable exeellent flax crops are produced. Flax, however, is eonsidered one of the new land erops, and as a large pereentage of the land has been brought under eultivation, this erop is not being grown to as great an extent as in the past. The average farmer has paid very little attention to varieties of flax. The most common variety grown is Premost, while some of the wilt resistant strains from the North Dakota Experiment Station are also on the market.

Rye: $\Lambda$ limited amount of winter and spring rye is produced. The diffienlty with winter killing has prevented the winter sort beeoming more eommon. Spring rye has given such a small average vield that it has not displaced any of the three foregoing eereals. Beerause of 
the small amount of this erop grown there are no valieties being recognized by the farmers.

Grasses: With the introduction of weeds and the need for diversification of crops more attention has been given each year to grasses. Timothy remains the most popular, largely beeause of the cheapness of the seed and its popularity in the Eastern Provinces and the States. Western Rye, Meadow Fescue and Brome are grown in limited quantities.

Legumes: Little attention has been paid to legumes, but where they have been tried out Alfalfa and Sweet Clover seem to give best results, while in most years the common Red Clover and Alsike can be grown with a fair degree of sueeess. 'This is especially true east of the Red River.

Intertilled Crops: As mentioned previously, foditer corn, sunflowers and roots are the intertilled crops that are grown in this district. The root crops have never come into favor beeanse of the expense in liandling and the amount of hand labor necessary. A five- to ten-acre pateh of fodder eorn is quite eommon on the farms throughout the district; where there is a silo a greater aereage is grown. The success with sunflowers as silage has displaced corn on some of the larger farms. The varieties of eorn usually grown are Northwestern Dent and Minnesota No. 13. So far Mammoth Russian is the sunflower that is being used.

282. Rate of Seeding.-The rate of seeding with plactically all erops is much heavier in this section than in most of the Great Plains Area. This is due to the comparatively heavy precipitation and the neod to crowd out all other plants. Wheat is sown at the rate of a 
bushel and three-quarters per acre, oats-two and onehalf to three bushels per acre, barley-two to two and a half bushels per aere, and all other erops at an equally heavy rate.

283. Dates of Seeding.-Experience has shown, other things being equal, that the earlier the crop, the heavier the yield as it is less liable to insect damage and plant diseases. Wheat should be sown as soon as the land can be worked; oats and barley about the first week after the land is fit for eultivation. Grasses and clovers are usually sown sometime between the 15th of May and the 15th of June; sunflowers during the month of May, and corn between May 20th and June 10th.

284. Weeds, Plant Diseases and Insects.-These are the three factors that cause the greatest loss throughout the district. Among the most pernicious weeds are perennial sow thistle, wild oats, Canada thistle. French weed and wild mustard. The plant diseases that have taken the greatest toll from the farmers are rust, smut and wilt. The insects are cut-worms, western saw-fly and ǵrasshoppers.

\section{Conclusion}

The suceessful farmers of the Eastern zone ale those who have selereted suitable orops and varieties and have adapted their farming practices to the comtrol of werds, plant diseases and insecots. Incidentally these practices conserve moisture but this has not beon the primary romsideration. 'The use of the hare fallow ancl oflese farmjug practions mentioned above have produced profitable cops practically every gear in the Red liver Valley. 


\section{DRY FARMING IN WESTERN MANITOBA}

By WV. C. McKillican, Superintendent Experimental Fara, Brandon, Man.

Tho average preeipitation for the ten years, 1911-1919, at Braudon, Manitoba, was $\mathbf{1 6 . 3 3}$ inches. The area which this represents is therefore of a semi-arid character and farm practices which conserve soil moisture and utilize it to the greatest degree are necessary for suceess in agriculture.

\section{SUMMERFALLOW.}

285. Importance of the Fallow.-The curner stone of dry farming in Western Manitoba is the summerfallow and so is it likely to continue for many years. Grain erops have enjoyed almost a monopoly of erop raising, and the summerfallow has served to clean the land, to conserve the moisture from one year to another and indeed has made grain growing possible in the pioneer and exploration stages of the country's development.

286. Methods of Fallowing.-The main features of a good summerfallow as praetised in this region are early plowing and thoroughness of after-cultivation. Both of these derive their importance from their efficacy in preventing the loss of moisture through weed growth. By early plowing we mean the first half of the month of June. May plowing has given no advantage over June but June has a very decided advantage over July. Depth of plowing is also generally believed to be an important feature of good summerfallowing. I believe this is usually correct, though our experimental results at 
Brandon have not corroborated this opinion. In the control of annual weeds one plowing followed by bare cultivation is better than two, but where couch grass or other persistent perennials are to be fought two plowings are justified.

The best implement for the eultivation of summerfallows is the stiff-tooth, duck-foot eultivator. Dise harrows and drag harrows should be used very sparingly if at all. Only in exceptionally loose, soddy or lumpy land is the use of the packer justified. A very full set of experiments at Brandon show no returns from its use.

287. Dangers of Fallowing.-The dangers of summer fallowing are soil exhaustion and soil drifting. It makes no provision for the return of plant food. This result (loss of fertility) has not been felt as yet in Manitoba, but it is something that plans for the future must take cognizance of. Soil drifting is here and is perhaps the biggest difficulty in Western Manitoba farming today. The grain and summerfallow system of the past must be modified to eontrol it.

288. Substitutes for Summerfallow.-Corn is the best substitute for the summerfallow. It should not be used in very dirty fields as the eost of clcaning is too great. The erop of grain produced on a well cultivated eorn ficld will usually equal and often cxeeed that on summerfallow.

Other intertilled erops such as mangels, turnips, potatoes or sunflowers, may also be used in the same way as corn, but none are so satisfaetory as corn so far as effectiveness as a substitute for fallow is concerned.

A pastured fallow is sometimes substituted for bare cultivation. It is not satisfactory in the real farming districts; the pasture erop uses too much moisture, and 
if there aro perennial weeds, persistent cultivation is necessary to kill them.

Hay crops may be used as a partial substitute for summerfallow. For this method to be suceessful the sod must be plowed early so as to be well rotted and to provide for the acemnulation of moisture. At the best there will not be as much moisture conserved as in a bares fallow but practical results have been satisfactory and it is only by the use of sod-forning crops that the soil drifting menace can be overeome.

\section{Rotations.}

289. Rotations now in Use.-The standard rotation generally in use in the western part of Manitoba is sum-

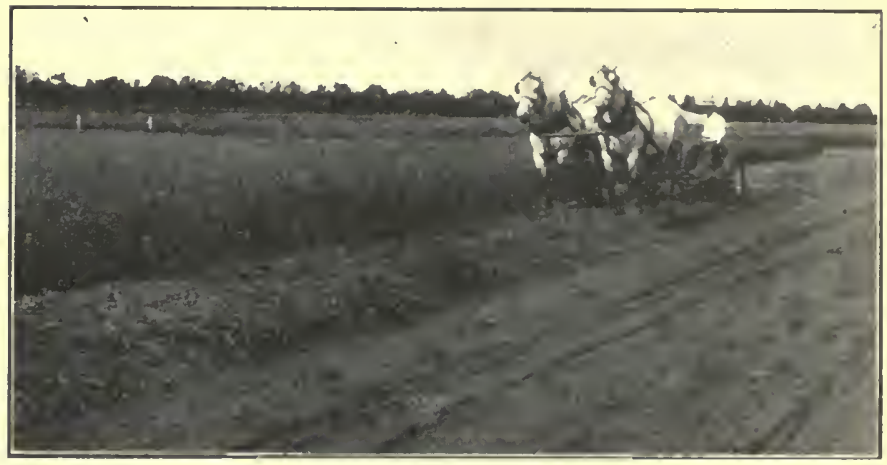

Fig. 103.-Cutíng Western Rye Grass and Alfalfa at Brandon Experimental Farm.

merfallow and thee erops of grain. Wheat practically always follows the summerfallow, the seeond year after fallow being somotimes wheat and sometimes oats and the third year oats or barley. In the early grain grow- 
ing years on a fertile soil this was found to be very satisfactory. The summerfallow once in four years was found to be sufficient to eonserve moisture and keep the weeds at least partly in eheck. This rotation with modifications represents most of the farming in this region. However as has already been indicated soil drifting is proving its inadequaey for a permanent system, and the great increase in weeds also indieates the need of a change.

290. Improvements in Rotation.-These have been indicated generally in diseussing substitutes for summerfallow. Greater diversity of crop is needed, including, first a sod-forming hay crop to return fibre to the soil and make feed for live stock which will result in manure. Second, the use of corn or other inter-tilled crop to provide additional live stock fodder and to cheapen the cost of production of wheat. Third, fall rye may be needed to eontrol soil drifting where it is so bad that grasses could not be started. A practical rotation which combines these features is as follows:

1st Year-Wheat.

2nd Year-Oats.

3rd Year-Summerfallow and partly corn.

4th Year-Wheat or, if necessaly, Fall Rye, seeded down with grasses and elovers.

5th Year-Hay.

6th Year-Hay or pasture plowed up in midsummer or earlier, and prepared for wheat.

'This rotation has one half the land in grain ("lops, one sixth in hay, one sixth in hay or pasture for the early part of the season and afterwards fallow, and one sixth in summerfallow and eorn. The seeding down to grasses is on summerfallow or corn land which is the only 
plaee to insure a eatch. The wheat which is our main erop is given the two most advantageous years in the six.

This rotation is offered as a praetical suggestion, which may be altered to suit varying conditions.

\section{0a. Dry Farming Crops.-}

Wheat:- The effect of shortage of moisture on a erop is to make it sacrifice leaf and stem for the development of the seed. Dry areas are eonsequently best fitted for the production of seed-bearing crops. Wheat is the great seed-bearing erop of Manitoba. Wheat made Manitoba, and will eontinue to be its chief support for many years to come. The object of diversification of erops, introduetion of new erops and live stock raising is not to replace wheat, but rather to make the continuation of profitable wheat growing possibile, where an attempt to grow nothing but wheat is suicide for wheat growing.

Marquis is at the time of writing (1920) the best variety of wheat for Manitoba. Red Fife has been entirely replaced and rightly so. Red Bobs has had a somewhat sensational period of advertising but is proving distinctly inferior. Kubanka, a durum variety, is being introduced to some extent on aeeount of drought resistance and supposed immunity from rust. Its low milling value makes it distinetly undesirable unless rust should beeome so bad as to make the growing of Marquis or other white-flour-producing wheats impossible. Ruby is a new variety somewhat earlier than Marquis and of similar quality which has not been fully tried out, but may be of importance for northern distriets.

Oats._-Oats fill an important plaee in Manitoba farming. The Banner and Vietory varieties are the leading favorites. 
Barley.-Manchurian and O. A. C. No. 21 both sixrowed varieties, are the best in use at present.

Fall Rye.-Fall Rye has been used to some extent as a means of eontrolling soil-drifting and combating wild (ats and is proving very valuable for these purposes.

Corn.-The great value of eorn in a erop rotation has already been mentioned. Northwestern Dent and Minnesota No. 13, are good varieties for this territory.

Sunflowers.-Sunflowers have been proven to be a good silage erop and ean fill the place of corn where it does not sucreed.

Mangels and Turnips.-Are not extensively grown but can be grown successfully.

Grasses.-Brome grass is our most drouth-resistant grass and is used to quite a degree for permanent hay and pasture. Its persistence makes it undesirable where more easily handled grasses will succed. Western Rye grass is probably the most generally useful grass for this territory. It stands drought well, yields almost as well as brome grass and being easily plowed up is a better rotation grass. Timothy is too dependent on moisture and the same is true of all grasses eommonly grown in humid countries.

Leguminous Hay Crops.-Alfalfa is the most valuable of these. It is grown with great suceess at Brandon Experimental Farm and by some few private farmers but is generally considered throughout this region as impossible to grow successfully. I believe the future will see it grown very much more generally, and that it will contribute very largely to the solution of farming problems. Sweet clover is being introduced to a considerable degree and has a great value where alfalfa eamot be grown. Its productiveness, hardiness, free seeding 
and adaptability give it a great value as a pioneer leguminous crop, but its coarseness and short life lessen its value. Red clover is only grown successfully in limited areas and can hardly be recommended for general use; the same is true of Alsike. Neither of these are really dry farming crops.

\section{DRY FARMING PRACTICES IN THE PARK BEIT OF ALBERTA}

By G. H. Hutton, B.S.A., Superintendint of Agriculture and Animal Industry, C.P.R., Calgary.

291. The Place of the Summerfallow.-As a general proposition it is not necessary to summerfallow in Central Alberta. The average precipitation during the year is in the neighbourhood of seventeen inches, sixty per eent. of which falls during the growing months. Other conditions than the amount of rainfall influence crops, such as the kind of soil on which the rain falls, its depth, and character of subsoil, velocity of prevailing wind, and amount of protection against sueh winds afforded by trees. The soil in the Park Belt of Alberta is a heavy black loam as much as three or four feet deep in many places, resting on a clay subsoil; there is therefore, practically no loss of moisture below, while the rate of evaporation is slow beeause of the fact that wind is not a serious factor to be reckoned with, also the large amount of humus in the soil holds the moisture tenaciously. Under such couditions a summerfallow stores such a large amount of moisture and liberates such a ligh percentage of nitrogen that the following crop lodges ninety per cent. of the time, fails to fill well, and is difficult to harvest. 
292. Suitable Rotation for the Park Belt.-A rotation which has given excellent results is as follows:-

1st Year.--IIay; manure during winter, 12 tons per acre.

2nd Year.-Pasture.

3rd Year-CPasture to July or early August, plowed 6 inches deep and cultivated.

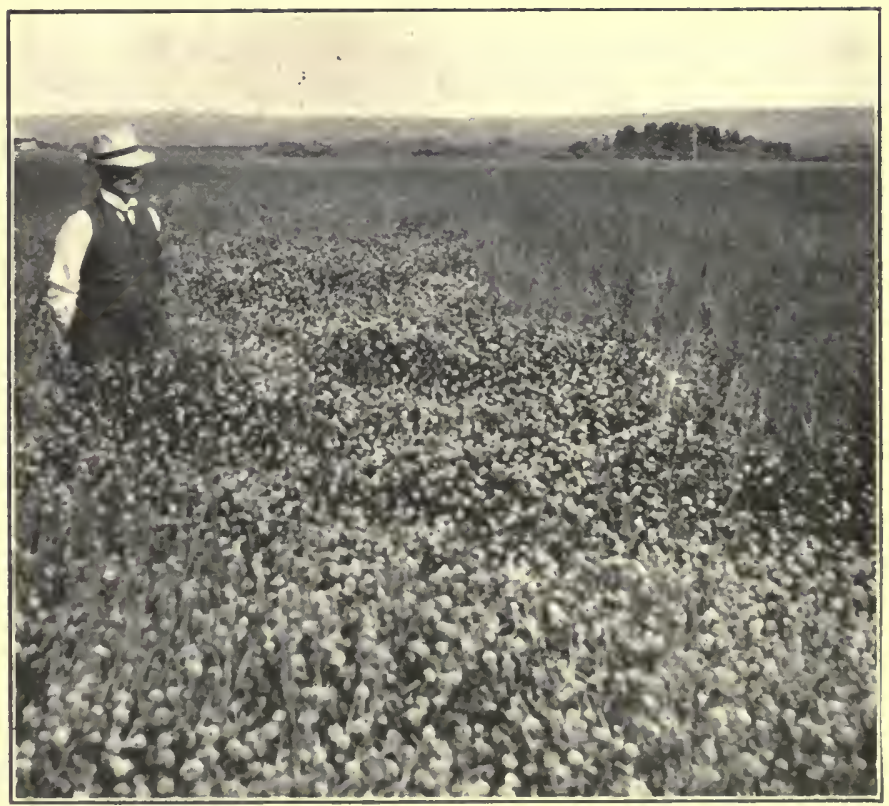

Fig. 104.-Alsike Clover and Timothy, Lacombe, Alta.

4th Yoar.- Whirat or wats.

5th Yoalr.-Oats.

6th Year.-Barley seeded down.

As a rule a first-elass stand of timothy and alsike or red revere ambinations an be obtained when soreded 
down with a nurse erop of barley. The land is cleaned to some extent by means of the eultivation given after the sod is plowed in the third year of the rotation, while the manure applied in the winter of the first year to the surface of the sod maintains fertility, and the weed seeds contained therein are largely destroyed prior to the plowing of the land in the third year of the rotation. On account of the liberal rainfall in May or June weed seeds germinate near the surface and in the manure, but lack sufficient roothold to come to maturity, and are thus destroyed. Such a rotation has resulted in the freeing of land from weeds to a remarkable extent, and has also built the land up as to fertility to a noticeable degree.

293. Corn vs. the Fallow.-Corn has been tested for some years in Central Alberta with rather indifferent suceess. During only about half of the years, has it given a crop which could be called profitable, and the risk thus indicated is too great to warrant the general use of this erop in that part of the country. It is admitted that an intertilled crop would be an advantage if it were practical in a large way, and economical use eould be made of the fodders grown. The sunflower may prove to be a plant which ean be ntilized in this section of the eountry to good advantage because it resists frost better than eorn, and from the data at hand would appear to be superior to eorn. When the size of farms reaches a better balance in relation to the amount of labor available this intertilled erop will command much more attention, and ean be used to splendid advantage in conjunction with silos. Such use of erops suitable for ensilage and of silos will result in doubling the stock-carrying eapacity of land. 


\section{The Preparation of Stubble Land for the Crop} Following.-If time permits, stubble land should be plowed six inches deep in the fall and plowing operations should be followed immediately by the use of a soil paeker, or if this implement is not available, by the drag harrow or dise. Such practice eloses the air space in the land, and prevents the loss of moisture through the eirenlation of air. The use of a packer immediately following the plow also permits of fall germination of weed seeds by firming the soil near the freshly turned surface, thus permitting the movement of moisture to these seeds. Packing promptly after the plow is an effective cultivation in preparing the land for work the next spring, as it levels as well as firms the soil. Such land, well plowed and double-disked after the paeker, is in good condition for the grain drill in the black loam soil of this section of the West.

295. Preparation of Grass Land for the Crop Following.-As indieated in the previous paragraph the plowing of grass land in July or early August is advised. The depth should be six inches and the plow should be followed by the packer or by the dise harrow operated in the same direction as the plow. As soon as convenient after the paeker the land shonld be given a double disking, after which it may remain for some time without further eultivation. It is advisable, however, to give such land the necessary work in the fall so that it will not require much more than drag harrowing, or a domble disking and drag harrowing at most, the following spring, in order to insure a good seed-bed.

296. Organic Matter, Legumes and Soil.-The importance of organie matter in the soil is shown by the wonderful crops which it is possible to grow when the virgin 
prairie is first broken. Such fertility is the result of the decayed organic matter of generations of plant growth, and its plesence insures yields of as much as seventy bushels of wheat to the acre and one hundred and forty bushels of oats. Such rich soils will produce profitable crops with light rainfall, as compared with the possibilities of poorer land with the same precipitation. No permanent system of agriculture can be maintained which disregards the maintenance of soil fertility through the use of barnyard manure and leguminous crops. It is quite possible to exhaust the fertility and to make barren, lands which, with ordinary good farming practice could be maintained in a splendidly high state of fertility. The ease with which alsike clover, red clover and other elovers can be grown with a nurse crop in Central Alberta, and the natural adaptability of the country for live stock should insure for this district perpetual resources of fertility in the land if any semblance of sane agriculture is followed.

297. Best Dry Farm Crops.-Cereals, legumes and grasses thrive. As to varieties, Marquis wheat, Banner or Victory oats; Mensury, O.A.C. 21 and Barks barley; alsike, red clover, alfalfa in some districts, sweet clover in some districts, and Giant Russian Sumflowers; timothy Western rye, and brome grass, are all suitable for different parts of the country.

298. Rates of Seeding in Central Alberta.-As a genelal practice rather heary seeding is advisable for the Park Belt in Alberta. The proper rate to sow, of course, depends upon the variety of grain, which involves size of kernel and the kind and condition of the land on which the grain is to be sown. Breaking and summerfallow well supplied with moisture will carly from one-half to 
one bushel more seed per acre than stubble land equally well eultivated. It has been found advisable to sow from two to three bushels of spring wheat per acre on well-enltivated breaking or summerfallow, depending upon the character of the land and its location, reducing the amount of seed on stubble land by half a bushel to a bushel, again depending upon condition. Oats should be seeded at the rate of from two and a half to three bushels per aere; barley at about two bushels per acre; sunflowers about ten pounds, and grasses and legumes at various rates according to the combinations used. Is a rule it is advisable to sow from twelve to fifteen pounds of Western Rye grass to the acre when this is the only variety being used, and this may be used as the basis for determining other mixtures.

299. Weeds. - The eradieation of weeds, while a serious problem, is not as acute a question in Central Alberta as in districts where wind has more sweep, and where the varieties of weeds have adjusted themselves to these conditions and spread over the whole territory by means of wind. The disking of stubble land following the binder, the following of the plow witl the packer to encourage germination of seed; giving the land a stroke with the drag larrow as early in the spring as it is possible to work the soil, and the drag harrowing of the growing (rop, together with the fall cultivation of .July plowed sod, will gradually reduce the weed population of a foul farm, and will keep a cloan farm clean.

300. Soil Drifting.- The drifting of soil will never be a serions problem in ('entral Alberta provided methods outlined in the paraglaphs immediately precoding are followed. The use of barnyard manure, the sereding down 
of land to grass, and the growing of such big-rooted plants as a number of the legumes are, will all assist in solving this problem before it arises, and it might be said in passing that this is the time to solve such a problem. The reclaiming of all soil which has been allowed to reach the drifting stage is a serious matter, and the said eondition should be avoided by every serious-minded, thinking farmer as he would avoid a plague. The following of the practice which will lead to the avoidance of the difficulty will also prove more profitable than those farming practices which lead to the soil-drifting eondition.

301. Plowing.-Good plowing is one of the most, if not the most important eultural operation on the farm. If this work is well done the battle is half won. Deep plowing is advisable in most eases, and in my judgment should never be less than six inches. Deep plowing of breaking is important, not only to permit of a good seedbed being worked after breaking without the necessity of backsetting, which is not feasible in the Park Belt, but is also neeessary in areas where there is much willow or other growth of tree roots to be turned down. The breaking plow must eut under these roots. Where the ground is very rich it is advisable to dise in the second crop on the stubble allowing more time for roots to rot. The deep plowing of stubble land provides a greater reservoir for the storing of moisture, and a better opportunity for plants to develop roots. The importance of taking pride in the various operations in connection with farm work eannot be overstated. The doing of work well is the only thing which will lift farm work from being a mere job to an interesting home-building oceupation. 
'THE SUMMERF ALLOW IN SOUTHERN ALBER'TA

By James Murray, B.S.A., Superintendent of Farms, Noble Foundation Limited, Nobleford, Alberta.

302. Climate.-The climate of Southern Alberta is eharacterized by light rainfall,-about fifteen inehes,-and the prevalenee of ehinook winds whieh blow intermittently throughout the year. The ehinook frequently attains the proportions of a gale; in winter it earries away a heavy snowfall in a few hours, and in spring and summer, and also frequently in winter, it not only dries out the surface soil very rapidly, but earries away in dust storms any soil in eondition to blow readily. On aecount of these eonditions-light preeipitation and heavy winds,- the Southern Alberta farmer on dry land must keep always before him the need of eonserving as mueh as possible of the moisture and of so working his land that it does not readily blow.

303. A Fallow Considered Necessary.-The general praetice on the farms of the Noble Foundation Limited is to summerfallow one half of the land each year. This is departed from more or less every year, as feed oats is frequently grown on land that was in erop the previous year; but only in very favorable seasons does the yield approaeh that from summerfallow. In dry seasons the yield from sueh land is very low. Over a series of years the further we depart from the method of fallowing one half eaeh year the less satisfaetory are the results. With most of the erop grown on summerfallow a fair return is seeured even in a poor year, and an excellent crop in a good year.

304. Summerfallow to Control Weeds.-The method followed in summerfallowing is planned to control weeds 
since most of the moisture lost during a fallow season is by the growth of weeds. 'The land to be summerfallowed is sometimes double-disked in the fall after the erop is removed, but more frequently, on account of lack of time in the fall, this operation is delayed until spring when it is done either during the progress of seeding or immediately after. This disking covers weed seeds and grain so that they grow readily. It kills millions of small weeds just starting and it breaks up the crust and leaves a light muleh on the surfaee. Sueh a surface makes a much better conneetion with the bottom of the furrow when the land is plowed than one that is hard, cracked and lumpy. In some seasons it may be advisable in order to eontrol weeds to dise a seeond time any land that is not plowed reasonably early, but usually one doubledisking is sufficient.

305. Plow Summerfallow Early.-The plowing of the summerfallow is started immediately after seeding and an effort made to have it eompleted before July. No single operation in summerfallowing is so important as plowing, so that eare is taken to do the work well, turning a furrow of from six to eight inehes deep depending upon how deep the land was plowed previously. Only a little subsoil is brought to the surface at each plowing. Immediately after plowing the land is packed by using either a subsurfaee packer or a dise rum straight or one noteh back. The paeking is more perfectly done when the land is fresh-plowed, so that an effort is made to have the packing done the same day as the plowing.

306. Controlling Weeds After Plowing.-After the plowing and packing of the fallow is done little more attention will need to be given for three weeks or a montl when weeds begin to appear. A start must be made at 


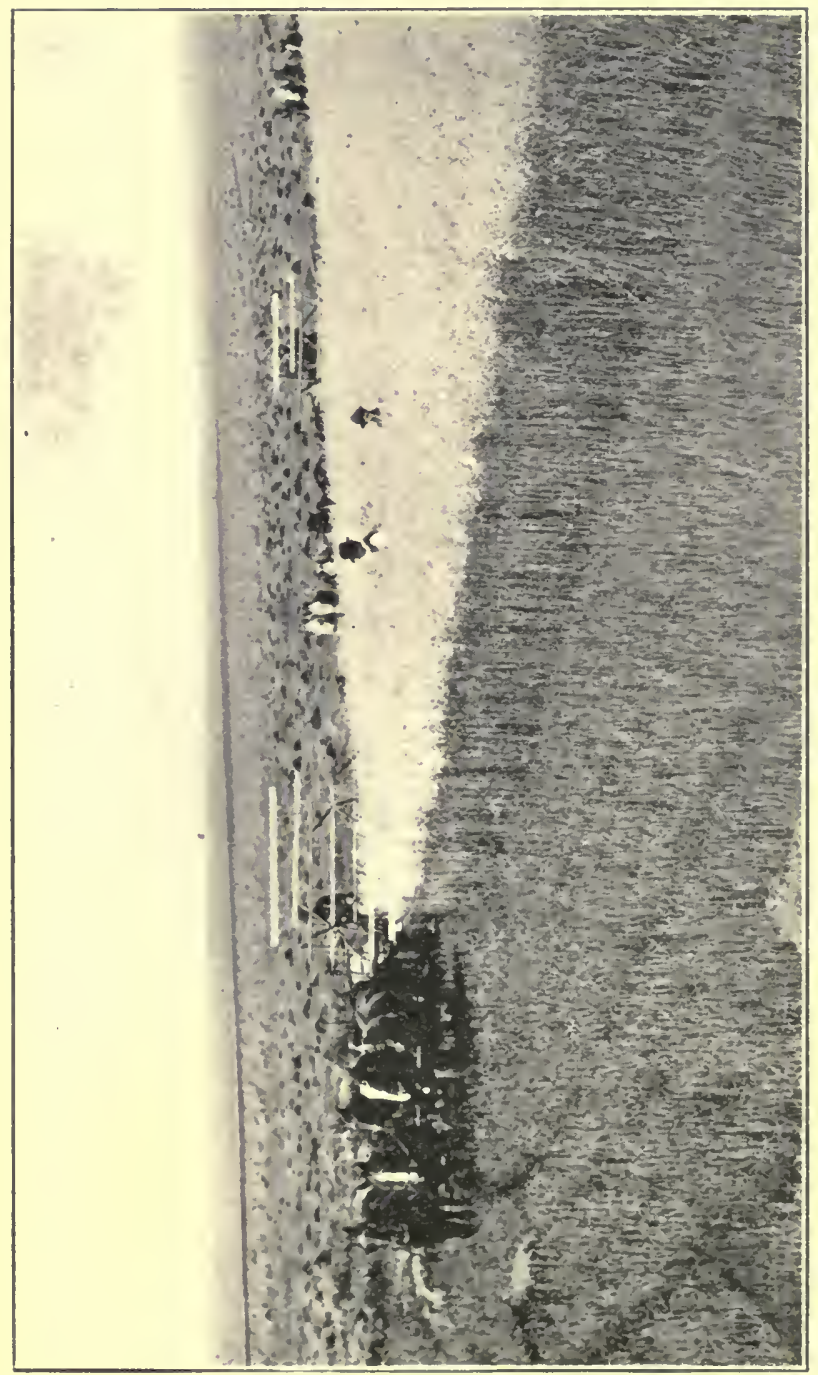


destroying the weeds when they are very small, else many of them will be large and have made a heavy draft on the moisture before they have been all killed. The implement used almost exclusively during the first two seasons as a weed destroyer in the fallow is the Rotary Rod Weeder. For several years previously a stationary rod weeder was used, but since the weeder with the revolving rod has been tried, the other one has been discarded. The Rotary Rod Weeder destroys all the weeds if it is used before they are too large, and leaves the land with a rough surface, not likely to blow. In some seasons it will be necessary to go over the fallow twice with the weeder to control weed growth, but the amount of work given is governed entirely by conditions. If weeds make their appearance and are likely to attain any size they should be destroyed.

307. Fall Treatment of Fallow.-The final operation on the fallow in the fall should be such as will leave it in a condition to best withstand heavy winds during the winter. Ridging with either a cultivator or a spring tooth harrow across the direction of the general winds is a good practice. The ridges not only serve to catch any soil that starts to shift, but they eateh and loold light snowfalls that are frequently swept off fields that have a smooth surface. By removing two-thirds of the teeth from the spring tooth harrow so that the ridges are one foot wide the draft is lightened and the work more effectively done at the same time.

308. Hoe Drill Preferred.-The hoe drill has been given a fairly good trial during the past two years and since it leaves the land much rougher than the other types of drills, it will probably come into fairly general use in districts where soil-drifting is particularly troublesome. 
When the hoe drill has been used on land not likely to drift, harrowing is advisable after sowing, but if drifting is feared the harrow had best be dispensed with.

309. Two Important Points About Fallowing.-In all the work on the summerfallow it is particularly important that two points be borne in mind,-the killing of weeds when they are small and the use of implements that will not pulverize the surface. The only safe time to use the disc harrow is before the land is plowed,-at other times it tends to pulverize too much. The drag harrow must, for the same reason, be used with great caution and drags of any kind that grind the surface should not be used on any account.

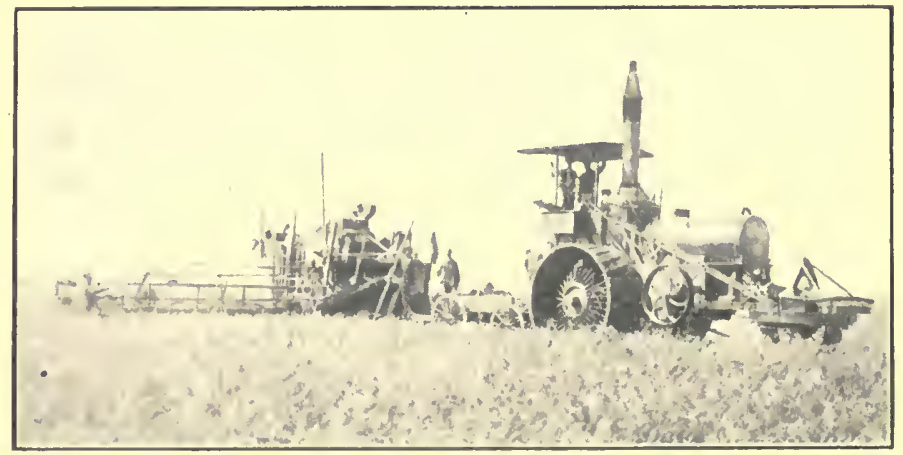

Fig. 105a.-Combined Harvester and Thresher.

Used in the Inter Mountain States, but very litte in the Grent Plains fnd almost never seen in the Canadian Whent Ficlds. 


\section{CHAP'TER XVII}

\section{THE PROBLEM OF CROP PRODUCTION}

The eontrol of crop yields and the maintenance of soil productiveness are problems that directly affect the prosperity of both the individual and the state.

An increase in net return equal in value to one bushel of wheat per aere on the land at present under cultivation in Western Canada would, at $\$ 1.00$ per bushel, pay the whole cost of the general expenditure for purposes of government of the three Prairie Provinees. The same inerease per acre per year for six years would more than pay Western Canada's share of the Great War debt.

An increase in net return equal to one bushel of wheat per acre would mean that approximately $\$ 35,000,000$ additional eash would be available for that section of the community engaged in supplying the needs of the farmer and in distributing his produets- the commercial and industrial interests; while a decrease of one bushel per acre would mean that an equally large amount of mortgages, loans and notes would remain unpaid for at least an additional year.

310. The Problem in a Nutshell.-If one busleel per. aere or more of an increase is to be obtained or even if one bushel or more decrease is to be prevented, the men who control our great resouree, viz., the soil, must know : 


\section{PROBLEM OF CROP PRODUC'TION}

(1) The factors that are essential to the growth of crops;

(2) The factors that affect the profit of crop produetion; and

(3) The factors that affect the permanence of a profitable agrieulture.

And they must not only know, but they must also put into practice, the means at their disposal for controlling or influencing the factors of growth, profit and permanence.

A statement and brief discussion of the fundamental principles underlying erop production, has seemed to us essential to a proper appreciation of the subject, both by the producer and the student of agricultural affairs. In this chapter we have, therefore endeavored to bring together the various phases of the question in such a way that the reader may get a general view, even though a brief one, of the relationship of its different parts to each other and to the problem as a whole.

\section{The First Part of the Problem-That of Growing} Crops.-As previously mentioned* the faetor's that must be provided before plants ean grow are:

(1) The seed-which contains the life principle, the reproductive part.

(2) Plant food materials-the chemisal elements of soil, water and air that are available to plants and that are necessary for growth.

(3) Water-a plant food itself and also a earrier of elements of plant food from the soil to the plant.

(4) Heat-withont which the life process of the plant, germination and growth, alunot go on.

*In Chapter III. 
(5) Light-for the synthesis or building up, in the leaves, of organic compounds from the inorganie elements of plant food.

(6) Air-which not only supplies a large part of the food of plants, but which in small quantity in the soil

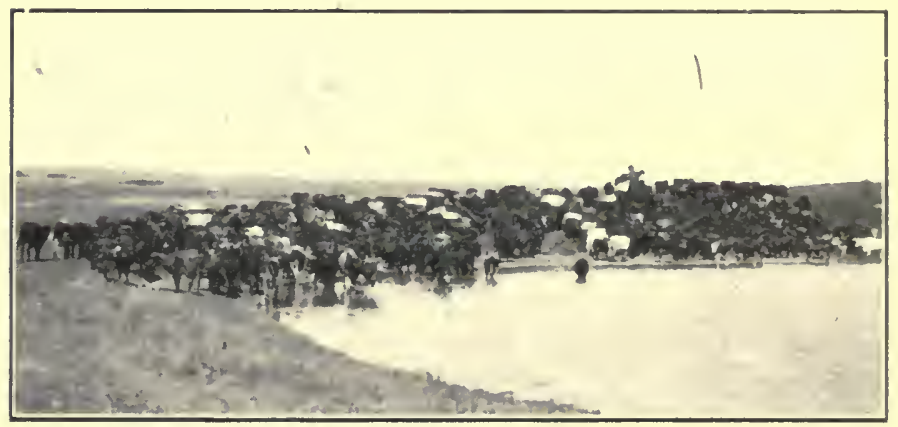

Fig. 106.-Cattle on the Range in Northern Saskatchewan.

provides a desirable environment for plant roots and at the same time plays a large part in the development of "available" plant food.

Fortunately for us nature provides most of these requirements with a lavish hand. It remains for man to increase, or at least maintain the supply of those that under his own climatic and soil conditions lave been either wasted or but sparingly supplied.

312. Light and Air Essential, but of Little Practical Importance.-Light and air are as important to the plant as plant food, water or heat, yet neither is as important to the erop grower for the reason that he finds both provided in very great abundanee. More liglit than reaehes the earth in most clinates where agrieulture is praetised, is seldom needed, and even if it were, the amount could not be inereased profitably. 
Nature supplies plenty of air above ground and in all except humid elimates, low lying soils, or very lieavy lands suffieient in the soil as well. It is our business only to regulate the supply so that the soil will eontain neither too mueh nor too little, but just the right amount for good tilth.

313. Frost Limits the Yield in Northern Climates.-The average number of days between, spring and fall frosts for a period of twelve years in the Central West varies from 73 in the north to 133 in parts of the south. The shortest period between frosts during the same length of time was 33 days for the north and 101 for the south while the longest frost-free period in each of these distriets was 112 and 163 days respectively. These figures probably represent the extremes in length of frost-free period for most of the present settled area of Western Canada.

It is apparent from these data as well as from aetual experienee that in northern elimates nature sometimes fails to provide enough heat to mature erops without injury from low temperature, and that, therefore, man must either add to the supply or take such steps as will offset the danger from frost. This is one of the two chief diffieulties facing the erop grower in Western Canada. There is need for developing a system of "Northern Farming" for northern regions just as there is a need for a system of "Dry Farming" for dry regions or one of "Humid Farming" for wet ones.

314. Water in the Soil Determines the Yield in Dry Climates.-Water is generally the limiting factor in erop production here. In other words, it is the chief eause of low yields. From 250 to 1,000 pounds of moisture are extracted from the soil and transpired by the plant into 
the air in the process of forming one pound of dry organie matter in the plants' tissues. In Western Canada we receive from 12 to 22 inches of water from the elouds annually. The preeipitation in most agrieultural eountries ranges between 10 inches and 150 inches per year. Our supply is small and our need is great. Man must make the best use of what nature supplies or furnish artifieially the shortage, otherwise he must be content with low yields.

In humid regions the supply of moisture from the elonds is generally suffieient to produce large returns. In arid and semi-arid elimates there is insuffieient rainfall to produce large erops every year with the result that the supply of water must be inereased by irrigation or steps must be taken to store a portion of one season's moisture in the soil for the use of the next season's erop, as by summerfallowing, or the use of intertilled erops.

The effieient utilization of our preeipitation for the development of the latent wealth that is in our soil is the biggest material problem Western Canada has to faee. She has made some progress towards its solution, but mueh work still remains to be done.

315. Plant Food Materials, the Limiting Factor on Poor Soils.-Of the eighty odd chemieal elements known to seience, fifteen may be used by plants, but only ten are essential to growth, and of these ten, all but four-nitrogen, phosphorus, potassium and ealeium-are provided in liberal quantity in the soil. The available supply of one or more of these essential elements of plant food is sometimes so small in humid climates that large yields on poor soils are an impossibility. Under these eonditions the terms "manure" and "fertilizer" are therefore almost synonymous with soil fertility, and the ehief 
problem of the erop grower is to maintain the supply of available plant food in the soil.

In Western Canada our normal soils are rich. The total supply of the chemical elements essential to plant growth is relatively large-so large in fact that on many soil types we are permitting ourselves to neglect almost wholly the question of its conservation. Our immediate problem is one of development rather than conservation. Nevertheless, it should be possible for us to do what older agrieultural eountries have done, viz., eonserve our soil resonrces while still developing them. The maintenance of soil produetiveness is likely ultimately to beeome one of our most serious problems and it would therefore seem to be the part of wisdom to direct more of our energies and resources toward the early solution of this difficult question.

316. The Importance of Good Seed.-The seed we sow may be good or poor. Its vitality may be lossened by frost or other injury, its vigor of germination lowered by disease and exposure, while the health and purity of the resulting crop may be serionsly affected by the presence of disease spores and weed seeds in the sample sown.

It is man's privilege to see that the seed he uses will germinate and germinate vigorously, that it is free from disease and admixture, and that it is a sort that is suited to the elimate and soil where it is to be planted. These are fundamental requilements. They constitute the primary elements of successful cop growing. They are the only things essential in good sered, and fortumately for us it is absolutely within our power to see that the seed we sow meets all these requirements.

317. Some Fundamental Facts. - The seed, plant food materials, moisture, leat, light ant air are all absolutely 
essential to growth. When each is provided in suitable quantity and in available form, the soil produees abundantly. If any one is lacking, no growth whatever will take plaee. And it is important to note that the factor that is present in smallest quantity in relation to the

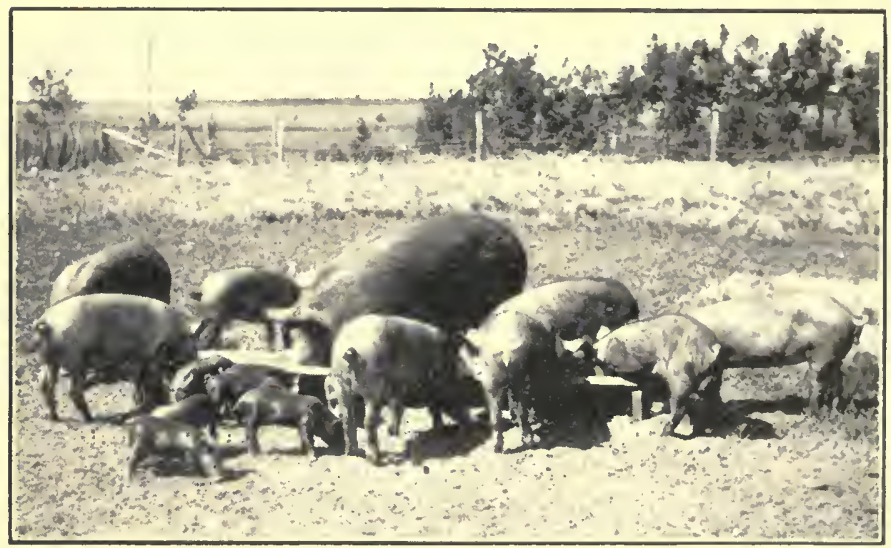

Fig. 107.-Bacon Hogs in the Making.

need of the erop will determine the yield. A ehain is as strong as its weakest link. The yield of a erop will be as high and no higher than the supply of the limiting factor will permit.

318. The Vital Part of the Problem-That of Profit.It is not enough that man should know the factors that are essential to plant growth nor that he should provide them. 'The intelligent farmer does not farm for his health alone. For him there must be some profit after the various items in the cost of production have been paid.

It is not diffieult to grow erops. It is not very difficult 
to produce large yields. But it is a difficult matter to grow erops at a profit whether the yields be small or large.

319. Factors Affecting Profit.-Suitable crops planted in productive soil according to up-to-date methods do not necessarily yicld profitable returns. In order that a profit may be assured, not only must all the essential conditions of growth be provided, but (1) the crop must be protected from weeds, insects, plant diseases and storms, and (2) either the eost of production or the selling price must be controlled.

320. The Cost of Weeds.-Weeds rob the erop of its plant fond and moisture and inerease the cost of produetion. It has been estimated by the Department of Agriculture that the weed crop of Saskatchewan costs her farmers $\$ 25,000,000$ a year, and probably this item does not eost the average farmer in Saskatchewan more than it does the average one in either of the other Prairic Provinees.

321. The Cost of Insects.-Inseet, animal or bird pests may lessen the yield or quality of the erop either before or after maturity. The Dominion Department of Agriculture places the loss through destruetion of crops by cutworms in one district in a single season at 35,000 acres. And the cutworm is only one of dozens of insects that take an annual toll from the farmer's erops.

322. The Loss from Rust.-Plant diseases nourish themselves on the tissues of plants and thus lessen the yield or quality or both. The loss to Western Canada from rust alono in the year 1916 has been estimated to average six bushels per acre. This at the Oetober price of $\$ 1.50$ per bushel on an area of aproximately 12,000,000 aeres, reaches the enormous sum of over $\$ 100,000,000$. In other years wheat smut, flax wilt, potato blight and other 
fungous or bacterial enemies have contributed to the large annual loss from plant diseases.

323. The Amount Hail Takes from the Profits.-Severe storms may injure the soil and damage the erop by soil "drifting" or by stunting, lodging or breaking down the plants, or by shattering the grain. The loss from hail is variously estimated at from one-half to two and onehalf per cent. of the total aereage, or on the basis of the present aereage a loss of 125,000 to 600,000 aeres. The damage done by hail in the year 1916 was eonsiderably greater than the highest of these pereentages. These storms eome as the insurance men say "by aet of Providence". It is fortunate that provision for earrying this risk has been provided by hail insuranee eompanies.

324. The Moral.-And yet these losses may oeeur even after the soil has been made produetive. It is apparent that one of three things must result:-(1) those faetors that affeet eost must be eontrolled, or (2) the price must be regulated by the produeer, or (3) the business of growing erops profitably cannot be eontrolled, and is therefore more or less of a gamble.

325. The Cost of Production and the Selling Price.A farmer, like any other business man, is legitimately eoneerned with obtaining the largest possible return for his labor and for the eapital invested'. This being the ease he is concerned with the profits of his business rather than witli his total output. Soeiety in general is greatly eoneerned with the desirability of inereasing the quantity of foodstuffs produced, sinee eost of living is thereby redueed. Herein lies the reason for the ery "Back to the Land" and the slogan "Greater Produetion" raised by those not living on the land.

The farmer from a purely business point of view is 
concerned with the problem of greater produetion only in so far as it tends to increase his own net profits. He has been forced to recognize that larger crops do not necessarily mean larger net returns, partly because the larger crop usually costs more to produce, and partly because a bountiful erop tends to reduce the selling price. Profit is measured by the difference between the cost of production and the selling price and farmers are concerned with maintaining, if possible, a reasonable and constant spread between the two.

Intelligent and timely eultural practices, hard work, good management and frugal habits will lower the unit eost of production and inerease the unit value. But the cost of the farmer's machinery and other equipment, the eost of his money and, to a considerable extent, the cost of his living are all fixed by eonditions and institutions over which he individually has no control. It is coming to be realized, however, that those factors which eannot be controlled by individual effort may be very considerably modified by colleetive and co-operative effort. Farmers' organizations seem to be in a fair way toward having tariff schedules, particularly those on implements of production, reduced, thereby reducing eost of production. Farmers' business organizations in the handling of agricultural implements and supplies in general have had considerable to do with keeping down the costs of these supplies. The eost of money to the farmer has also been reduced by organizations, such as rural eredits soeieties and farm loan associations designed to meet the needs of the agriculturist. In general the cost of production seems to have been materially redueed whereever farmers organizations have made a determined effort to compete in the handling of farmers" husiness. 
'The priee a farmer gets for his produets is fixed by the law of supply and demand, the tariff sehedules, the eost of transpcrtation and the eost of handling by middlemen. Here even more than in the cost of produetion the faetors that determine the selling priee are beyond the influenee

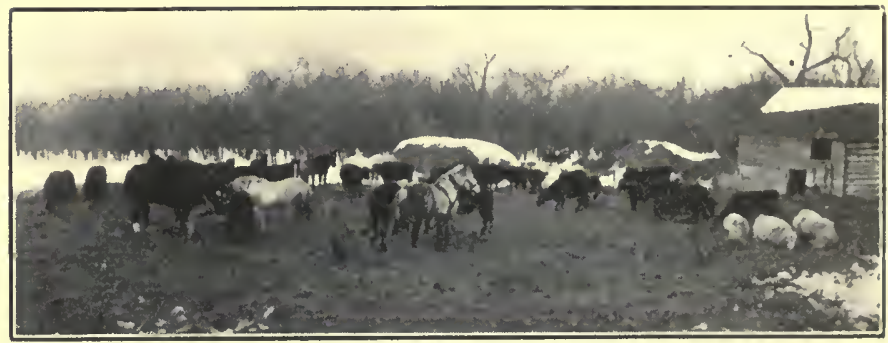

Fig. 108.-Manitoba Farm Yard Scene, in Winter.

of the individual produeer. Individually a farmer ean influenee the priee of wheat about as mueh as he can the state of the weather. If he is ever to get a larger proportion of the eonsumer's priee it seems apparent that it must be through eo-operative effort.

The priee of erops in the future as in the past will in a large measure be eontrolled by the law of supply and demand. The world's demand is relatively eonstant. May not the supply be made more uniform? By a better knowledge of the probable market requirements may it not be pessible to avoid over-produetion of one erop and under-production of another with consequent loss in net returns? May it not also be possible to arrive at a valuation of the serviees of transportation eompanies and middlemen, with fairness to all eoneerned? These are problem. that farmers, transportation eompanies, middlemen and eonsumers must solve colleetively. In this way 
only will the interests of society as a whole, rather than that of ary class or section of it, be equitably served.

326. The State's Third of the Problem-That of a Permanent Agriculture.-The eonditions that affeet growth and the factors that affect profit are and will continue to be the chief considerations of the individual farmer. Yet a third set of eonditions of vastly greater importanee to the future of the state, viz, those that affect the permanence of our agrieulture, remain to be considered.

We are hearing much to-day on the one hand about the "depletion" of the land, the loss of "fertility" and the "exhaustion" of plant food from the soil; and from another quarter about our soil being "the riehest in the world", and about its supply of plant food being "inexhaustible".

We hear of some land that after continuous eropping and no return of plant food, is produeing as mueh as, or more than it did a generation ago, and we are led to ask ourselves, "Do soils wear out?" "Can they become depleted?" "Are they being exhausted?" These are questions upon our solution of which the future nutcrial suecess of Western Canada very largely depend.s.

What is fertility? In its narrowest sense it is plant food materials in the soil, - the ehemical substanees plants use in growing. In its broadest sense it is ability to produce erops, and ineludes (1) "available" plant food, (2) tilth, or a favorable eondition of the soil with relation to water and heat and air; (3) health, or freedom of the soil from disease, and (4) purity, or its relative freedom from weeds and weed seeds. In its broadest sense "fertility" moans productiveness, which is not neeessari!y synouymous with, although generally elosely 
related to, the eontent of plant food materials in the soil.

Soils do not beeome literally "depleted" or "exhausted" of the plant food elements they eontain, although the amount may be seriously lessened, but the land may become depleted or exhausted of its "productiveness". These so-ealled "depleted' soils may at any time be made produetive, but the trouble is they eanuot be made to produce a profit until such time as the pressure of population or some other eeonomic condition inereases the price of soil produets or lowers the eost of production. And if this does not happen, sueh soils remain unprofitable and unproduetive. In any ease they seldom redeem themselves. They generally have to be built up by eapital brought from some other souree. Such soils beeome not only a source of loss to the man who operates them but also a burden to the state which indirectly has to bear, not only the loss from their inefficient use, but also the eost of their redemption.

327. Factors that Affect Permanence.-The clief faetors that affect the maintenance of productiveness in any community have already been mentioned, but will bear repeating. They are:

1. The maintenanee of soil tilth, which in practice generally means the maintenance of organie matter.

2. The maintenanee of soil health, or the prevention or ecntrol of plant diseases that live in the soil.

3. 'The maintenanee of soil purity, or weed eontrol, and last but by far the most important in the long run

4. The maintenance of a sufficient amount of available plant food.

In addition to being productive, a permanent agriculture must also be a profitable agriculture.

And now, having considered this many-sided problem 
the farmer has to solve, let us examine the nature and effeetiveness of the instruments he has been given with which to achieve his purpose.

328. The Means at Man's Disposal for Controlling or Influencing the Factors of Growth, Profit and Permanence.-

The instruments now available for eontrolling or influencing the factors of growth, profit and permanenee are:

1. The ehoiee of suitable erops.

2. Suitable erop management practices.

3. The inprovement of erops by selection and breeding.

4. Irrigation or drainage, or both.

5. Tillage.

6. Suitable erop rotations.

7. The use of live stock.

8. The applieation of business prineiples to the management of the whole farm-the land, the stock, the labor, the finanees and the machinery and other equipment.

9. The use of legunes and nitrogen fixing bacteria.

10. The utilization of manures.

329. The Choice of Suitable Crops.-Nature has giren us some plants that resist disease, some that resist frost, some that resist drought, and some that avoid these eonditions. $\Lambda$ great number of erops suited to different systems of farming are available to ehoose from, and the experience of farmers and the records of our experiment stations are fast teaching us the ones that are best suited to our elimate and soil. The value of some new and untried erops has yet to be determined, and the suitability of different classes and types of erops for pecuilar loeal soil and elimatic conditions is a line of work that needs greater attention. But our present knowledge, if ntilized, 
is suffieient for our present need, and we have faith that new plant forms will be developed or diseovered that will meet any pressing requirements of the future.

Some doubt exists eoneerning the relative value of different varieties for some loeal climatic and soil conditions, but these are being quickly dispelled. One needs but

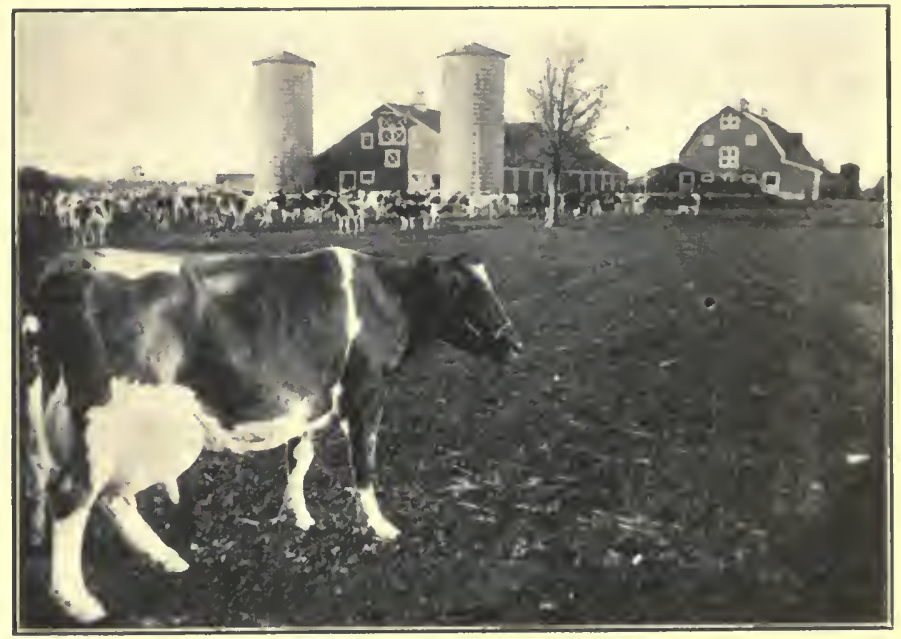

Flg. 109.-Dairy Herd in Red River Valley.

refer to the nearest experiment station for the results of comparative tests. If these are not conclusive, co-operative trials on one's own farm ean easily be made. It is sufficient here to refer the reader to the reports of the different experiment stations, and to urge him to keep informed on the results of offieial tests.

330. Suitable Crop Management Practices.-The eleaning of the seed, its treatment for disease, the time, rate and depth of planting, and the time and method of har- 
vesting and curing of crops, offer many opportunities for error. In new countries, and particularly where the settlers are unfamiliar with farming, the best practices have to be learned by experience, and in the early days of such settlements this experienee is often gained at a very great cost. But even now there is a considerable fund of information, sufficient at least to make a safe working guide to the suecessful prosecution of each of these, even under the diverse elimatic conditions the different parts of the West present. The experimental farms have been given the responsibility for getting more aceurate information on this subject and their results are being made available to all in their annual reports and periodieal bulletins. No one need long remain in the dark eoncerning the "crop management" practices now recognized as suitable in different portions of Western Canada.

331. The Improvement of Crops.-Men are improving crops by doing two things: (1) by the negative process of preventing them from deteriorating, and (2) by increasing their hereditary power with respect to yield, quality, or some other economie character. The first is the business of the farmer, the responsibility for the second lies with our experiment stations.

Our crops have in many instanees deteriorated sadly by admixture with weeds and seeds of other erops, by attacks of disease, by drought and frost and by improper eare of the seed. The prevention of each of these in so far as it is possible is necessary in order to maintain productiveness and quality. It is not always within the farmer's power to wholly prevent these conditions, but ordinarily he ean do mueh to lessen their ill effeets.

The hereditary power of our erops has been and is being improved by selection and by artificial crossing, 
followed by selection. It is true generally that "like pro. duces like", but it is not always so. Variations oceur in all our erops. It is necessary then that the undesirable variants be eliminated and that the favorable ones be isolated and tested out, and if better than the parent, inereased and made available to the erop grower. 'This is accomplished by the selection of individual plants, the propagation of the seed in a "pure culture", the testing of its yield and constancy for a number of years, and then increasing it as quickly as possible and making it available to the erop grower.

"Crossing" is resorted to, first, in orler to produce variation so as to give greater opportunity for selection, and second, to engraft on a race some desirable character possessed by another. Crossing or breeding, the intermixture of the blood of two parents results in many new combinations of characters, some one of which may be the very one desired by the breeder. This favorable plant must be found, isolated, tested out, the seed increased, and then distributed. Practically all of the common crops now grown have felt the influence of the breeders' touch. Marquis wheat, Victory oats, O.A.C. No. 21 barley and N.D. No. 959 winter rye are familiar examples of improvement by seleetion and breeding.

332. Irrigation and Drainage.-In warm, dry climates, moisture is the limiting factor in crop production. Where water can be secured by artificial means, a profitable agriculture generally results. We practise irrigation in parts of Western of Canada, but over most of our comntry, it is not possible to do so, because water is not available.

In wet climates and low lying soils moisture may also limit the yield, not because there is too little, but because 
there is too much in the soil. Under such conditions the removal of the surplus by artificial surface or underground drainage is just as necessary as the addition of of water to dry lands. Outside a few local areas and on low, flat lands and alkaline soils, land drainage is not a serious problem in the Prairie Provinces.

333. Tillage.-Tillage is the greatest means at man's disposal for controlling the conditions that at the present time are causing low yields on the farms of Western Canadia. It is also by far the largest single item on the cost side of the erop account. Tillage is a universal practice, but on account of the great variation in soil, temperature and moisture conditions in different countries and in different parts of the same country, the various methods employed art still fruitful of debate and somewhat diffienlt to determine satisfactorily. At the present time in the West, tillage is one of the most important subjects connected with erop growing, yet it is one upon which conclusive data concerning the relative value of different practices is not available for more than a few sections of the country. In the dry year of 1914 the yields of Marquis wheat at Saskatoon ranged from six bushels per acre to thirty-two. In the wet year of 1915 they ranged from seventeen to forty-seven. The range in yield in each of these seasons was due entirely to the different tillage practices followed. This subject is diseussed at some length in chapters VII to $\mathrm{X}$.

334. Crop Rotations.--The most reliable information the world affords on the value of crop rotations shows that land in England when cropped continuously to wheat for sixty years produeed an average of fourteen hushels per aere, and when grown in a rotation of turnips barley, elover and wheat it prodneed twenty-five bushels 
per aere every fourth year for the same length of time. The most reliable information that America affords shows that eorn in Illinois when grown continuously for twenty-nine years produced twenty-seven bushels per acre, while in a rotation of eorn and oats it produced forty-six bushels, and in a rotation of corn, oats and clover, fifty-eight bushels per acre.

But we are not living either in England or in Illinois. Their rotations do not suit the conditions found here. Yet our rotations of the future must include, as do those of older regions, a legume crop, an intertilled or fallow erop and a money erop. Until recently in Western Canada, neither legumes nor intertilled crops suitable for use in a large way were available, or if so were either not well suited to all conditions or did not lend themselves satisfactorily to practicable changes in our present system of farming. Some difficulties have yet to be surmounted before paying crop rotations are discovered and firmly established, but at least we are fast becoming familiar with the crops we must depend upon not only as nitrogen gatherers and as intertilled erops but also as money crops.

In the meantime the spread of weeds, the "drifting" of soil and the loss of organie matter are in many places lowering the profit from grain farming so materially that resort to hay crops oceasionally is being practised. In other places corn is eoming to be a partial substitute for the fallow. It is possible that these crops, together with alfalfa, or some other legume sueh as sweet clover, may be the stepping stones to more desirable erop rotations.

335. Crop Rotations and Live Stock.-The introduetion of a large acreage of forage crops on the farms of Western Canada will require an enormous initial outlay of 
capital for stoek and for fencing and buildings. The greater part of this money must be made on our farms. The problem then will be solved but slowly. It is largely a rotation, a farm management and an economic problem. The purely agronomic or crop and soil phases of it are the least difficult to answer.

In our opinion we shall not control weeds and drifting soil permanently until we adapt our systems of farming to meet those conditions which have caused and are now causing low yields and poor quality in our crops. That adaptation will include a rotation of crops designed chiefly for controlling weeds and drifting soil, for lessening the cost of production and for building up a more permanent agriculture. It will necessarily include live stock, (1) to make use of the forage erops that must be grown, (2) to lessen the amount, and thereby the cost of the tillage necessary to control weeds, (3) to lessen the risk of our one-crop system and (4) to turn the wastage and by-products of the farm into a realizable asset.

336. Business Farming.- It is not long since the farmer did not need to be a business man. He produced his own food, he grew and manufactured his own clothing and built his own house. IIe lived unto himself largely. He needed little business training.

The modern farmer eannot live unto himself. He does not produce his own clothing nor the material to build his house, nor does he grind his own wheat into flour. - To-day he must spend, even for the necessities of life. Therefore he must have something to sell. In other words, the modern farmer must be a business man.

It does not take long to learn the art of farming, but unfortunately it takes some of us a long time to learn the art of successful farm business. It would seem that we 
as individuals might with profit give more attention to mathematies in relation to our business. Our profits are determined by the differenee between our receipts and our expenditures, and not by our gross ineomes. Let us know, if possible, the essentials of our own business enterprises. It would seem also that we as a class must praetise greater eo-operation. Onr eo-operative enterprises have aceomplished mueh in the interest of the farmer, ehiefly in the marketing end of his business, and they have still much opportunity for serviee. At the same time let us not forget that as individuals we ean still do mueh to lower the eost of produetion and to lessen the risk in farming, both of which are direetly related to profit.

337. Legumes and Inoculation.-The air over every aere of land eontains seventy million pounds of nitrogen, the most costly of fertilizing elements. This amount is suffieient to supply the nitrogen of fifty bushel crops of wheat every year for a million years, yet farmers in some eountries are paying twenty cents a pound for nitrogen to put on the land. Nitrogen in the air can be secured at no eost to the farmer if he will but grow some legume erop at intervals. 'This kind of crop when inoeulated with nitrogen-fixing bacteria, has the power of drawing upon the immense store of nitrogen in the air.

In suel of our virgin soils as are rieh in nitrogen it is possible that the use of legume erops may not now result in large inereases in yield. Investigations at present under way will soon answer that question. In the meantime the fundamental faet regarding legumes should not be forgotten. Neither should it be forgotten that all our soils are not virgin, nor are all rieh in nitrogen. 
338. The Use of Manures.-Land eropped eontinuously to wheat for fifty-five years in England produced an average yield of 12.9 bushels per aere, while in a nearby field the wheat in a rotation that was heavily fertilized gave an average of 35.5 bushels.

In Illinois, as was stated previously, land eontinuously eropped to eorn for twenty-nine years produeed an average of 27 bushels per aere, in a rotation of corn and oats, 46 bushels and in a rotation of corn, oats and elover, 58 bushels per acre. In the latter rotation when the land was manured the yield was 81 bushels, and when manured and given commereial fertilizers as well, the yield was 96 bushels of shelled eorn per aere.

At the present time we eannot get such large inereases from the use of either manures or eommercial fertilizers, although we ean and do get good returns from the intelligent use of manure, even on onr new soils.

In this conneetion a definite statement regarding the amount of the more important food elements in western soils and the actual results of the application of mamures and fertilizer's to them may not be out of place.

In the surface $62 / 3$ inehes of the normal Saskatehewan soils so far analyzed by the Department of Chemistry of the Provincial University, the nitrogen supply ranges from 3,000 to 14,000 pounds, the phosphorous from 1,000 to 3,000 pounds, and the potassium supply from 14,000 to 45,000 pounds. Assuming that the straw were all returned to the land, the amount of these elements removed from the soil in the production of one bushel of wheat would be $12-5$ pounds of nitrogen, 1-5 pound of phosphorns and about 1-5 of a pound of potassium.

It is, therefore, apparent that if all of this plant food could be utilized by arops without loss, there is anough 
nitrogen to produee from 2,000 to 10,000 bushels of wheat, enough phospliorus to produce 5,000 to 15,000 bushels and enough potassium to produee from 70,000 to 225,000 bushels in the surfaee $62-3$ inches of one aere.

Man would take out all this wheat in a year if he could, and leave none for future generations, but Providence has wisely provided that only about 2 per eent. of the content of certain elements, 1 per cent. of others and 1-4 of 1 per cent. of still others can be annually released from the soil and taken up by growing plants, so that we cannot literally deplete our soils of their potential wealth by eropping even if we would; but we ean and are depleting even the best of our soils of their surplus wealth and their productiveness. We must not let the supply of total plant food get so low that the small percentage that becomes available to plants annually will be insufficient for a large erop.

It may be asked, why add manure or other fertilizer to soil eontaining so much plant food? The answer is to be found in the proportion of the plant food in the soil that is available to plants. The elements added in deeayed manure are quickly available to the plant, while much of that found in the soil is not. And in addition, decaying organie manures not only improve the physieal condition of the soil, lessen its tendeney. to blow, and improve its moisture holding power, but also liberate or make available other more or less insoluble plant food elements. Of course it eosts money to handle manure and there are some mincr objections to its use under eertain eonditions. Nevertheless at many different places in the West it has increased the yield of every erop tested, even on rich land.

If a system of permanent agriculture is to be estab- 
lished on our western prairies-and our future welfare depends upon its establishment-we must not carry our wheat system too far. We cannot waste the fertility of our soil and still have it. To-day we are selling our soil fertility at the rate of 25 cents for each bushel of wheat sold. We individually ean afford to do that for some time, but the State cannot afford to permit us to do it indefinitely.

339. In Conclusion.- - It is the moral duty of the erop grower to produce as large crops as can be profitably grown. It is the double function of society to see (1) that the farmer is not hampered in this purpose by economic disadvantages and (2) that agriculture receives such cooperation and encouragement from the State as will enable it to establish a more permanent system of farming.

Intelligent tillage, the choice of suitable crops, and suitable cultural practices, will enable us to develop the resources of our soil. Business methods and in some places a rotation of crops and the introduction of live stock will enable us to produce crops more profitably, but only the use of legume crops, the practice of a crop rotation and the return to the soil of some of the plant food we remove in crops and in fallowing will enable us to build up a permanent agriculture, and a permanent agriculture is absolutely essential to the future wellbeing of the State.

In the final analysis our ultimate success as a nation depends not only upon our ability to produce profitable crops now, but upon our ability to keep on producing profitable crops. 

APPENDIX 


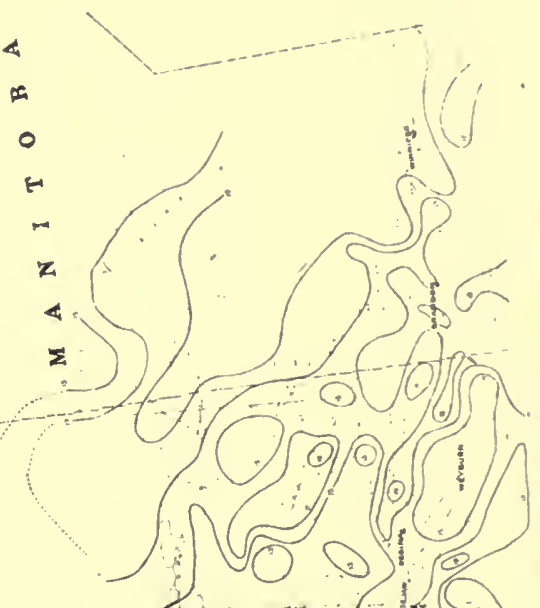

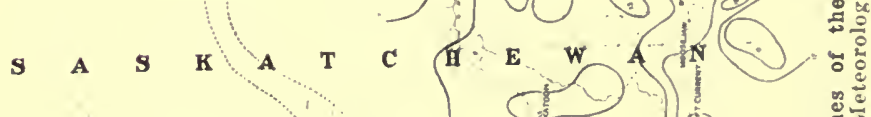
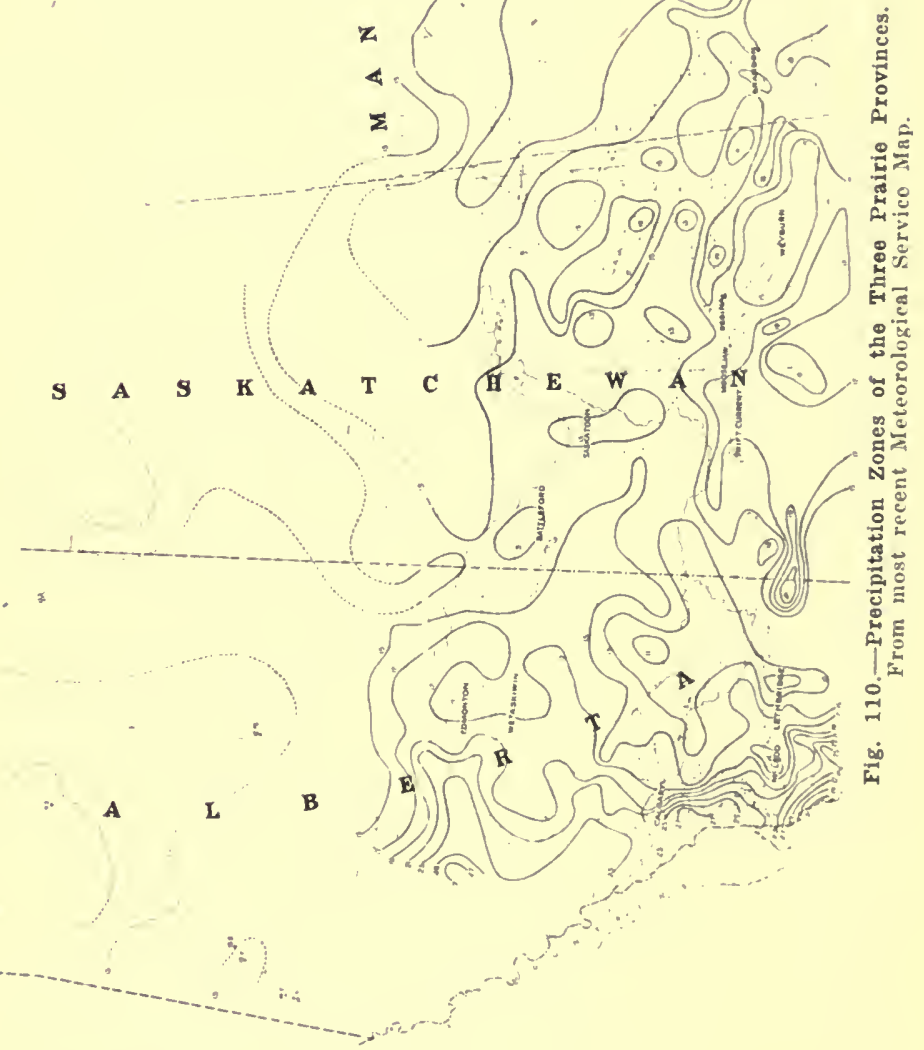


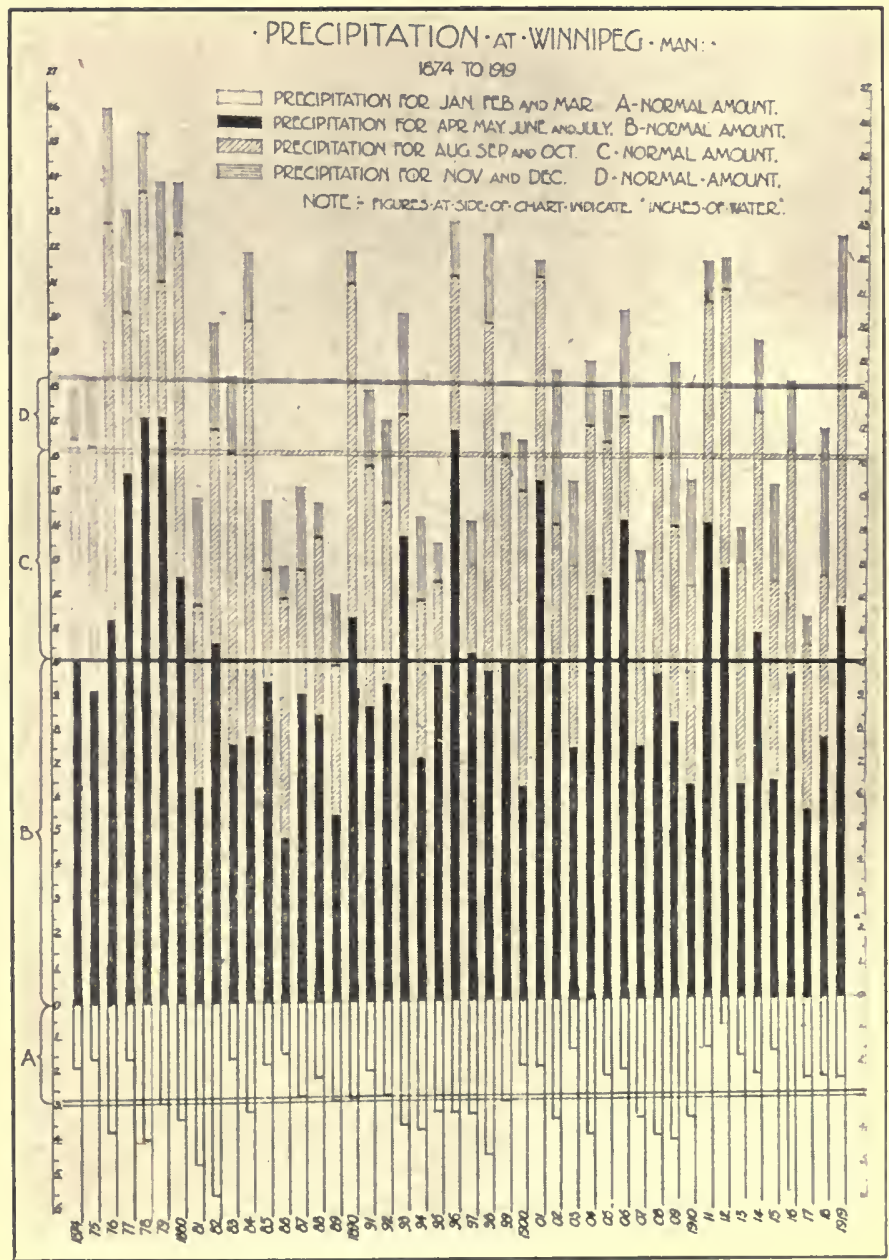

Fig. 111.-Precipitation Record-Winuipeg, Man. 


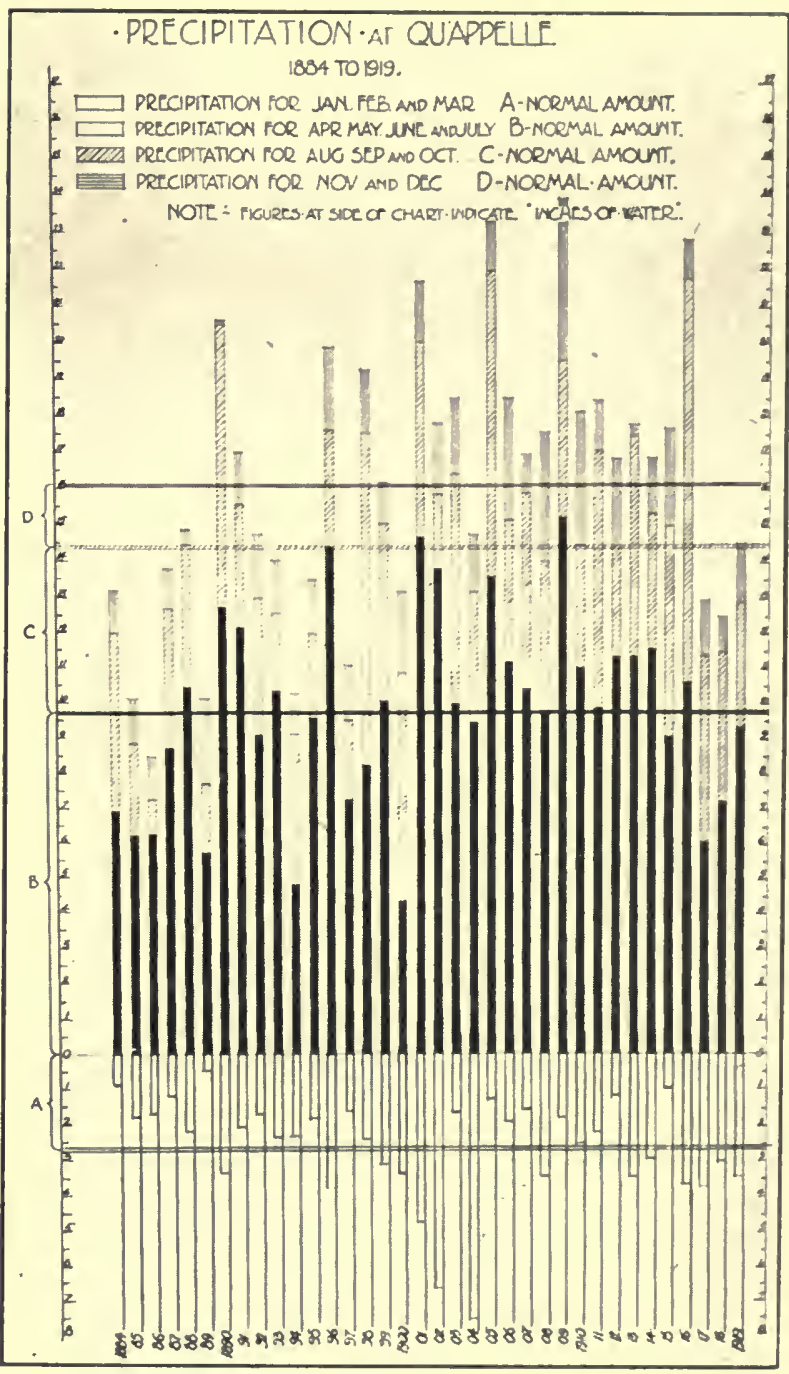

Fig. 112.-Precipitation Record-Qu'Appelle, Sask. 


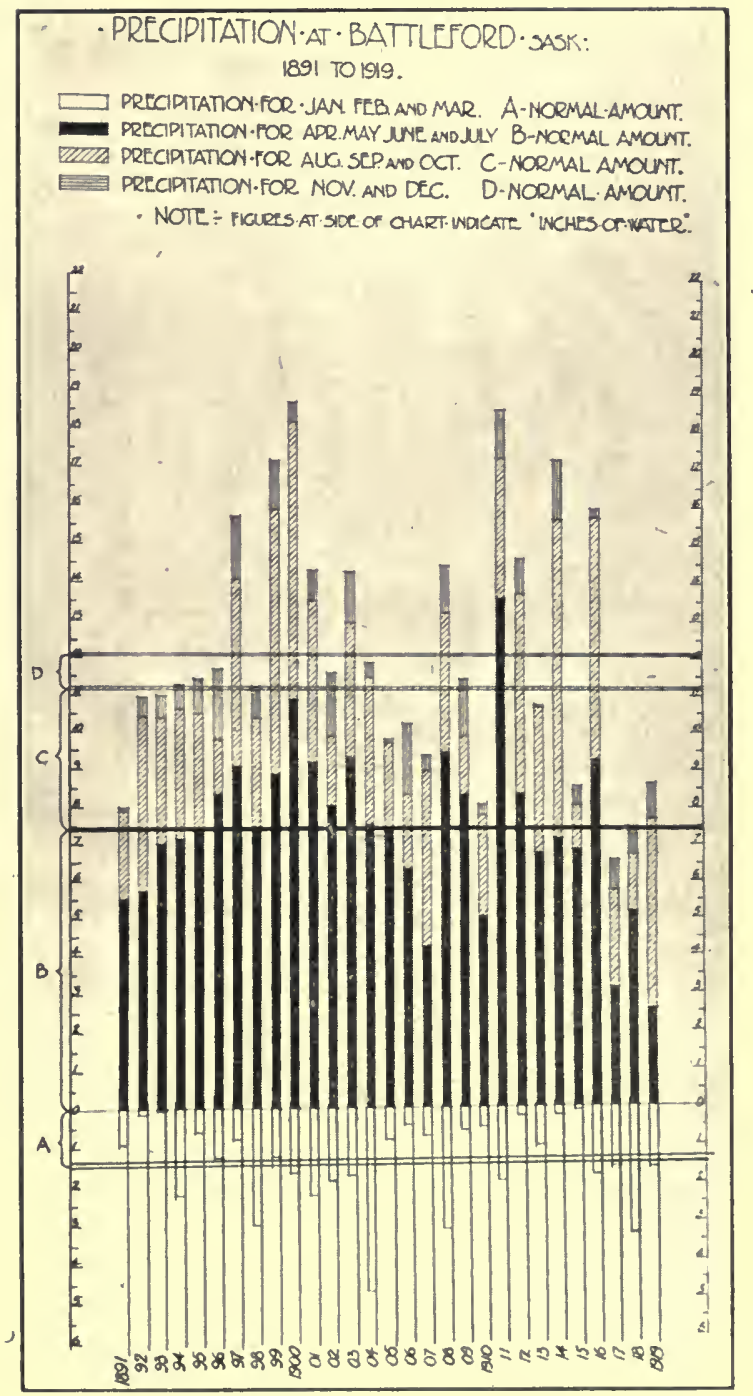

Fig. 113.-Precipitation Record-Battleford, Sask. 


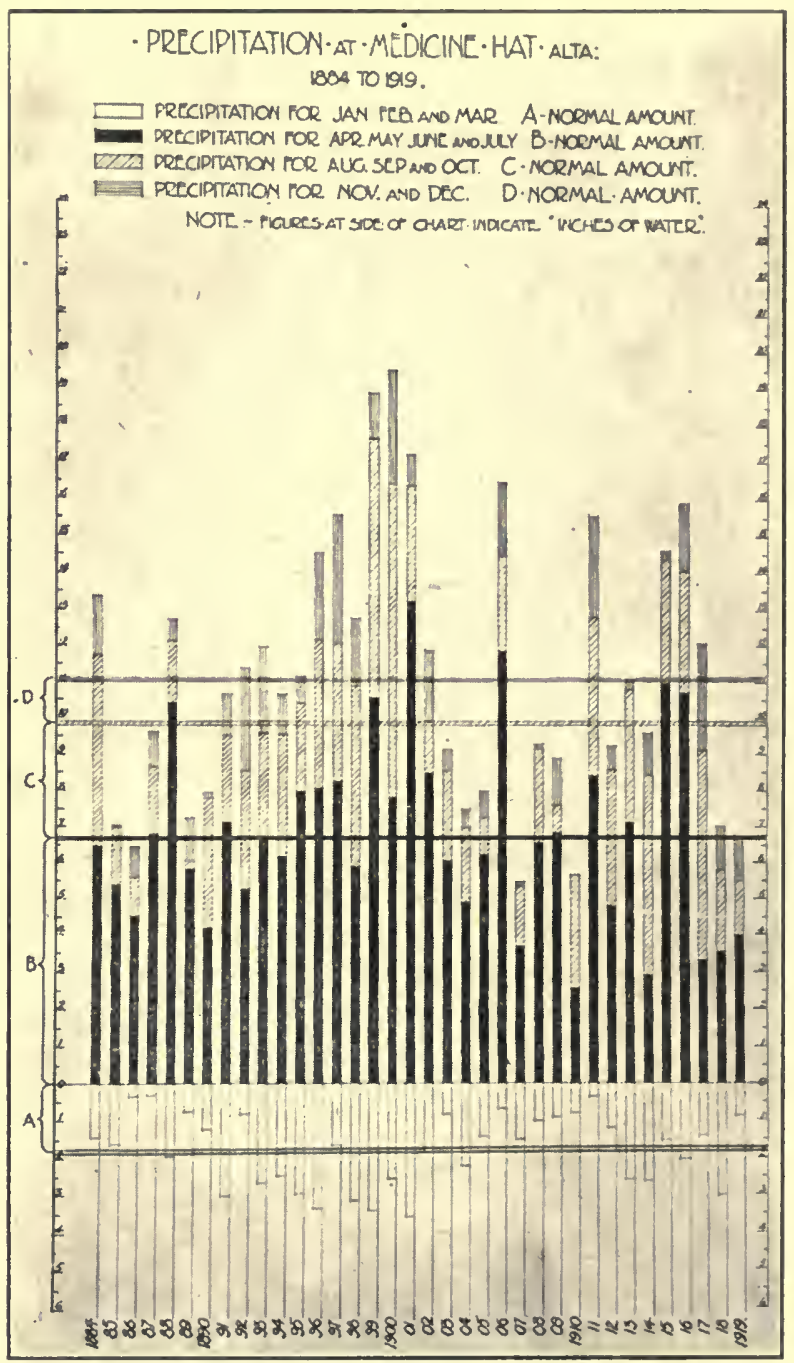

Fig. 114.-Precipitation Record-Medicine Hat, Alberta. 


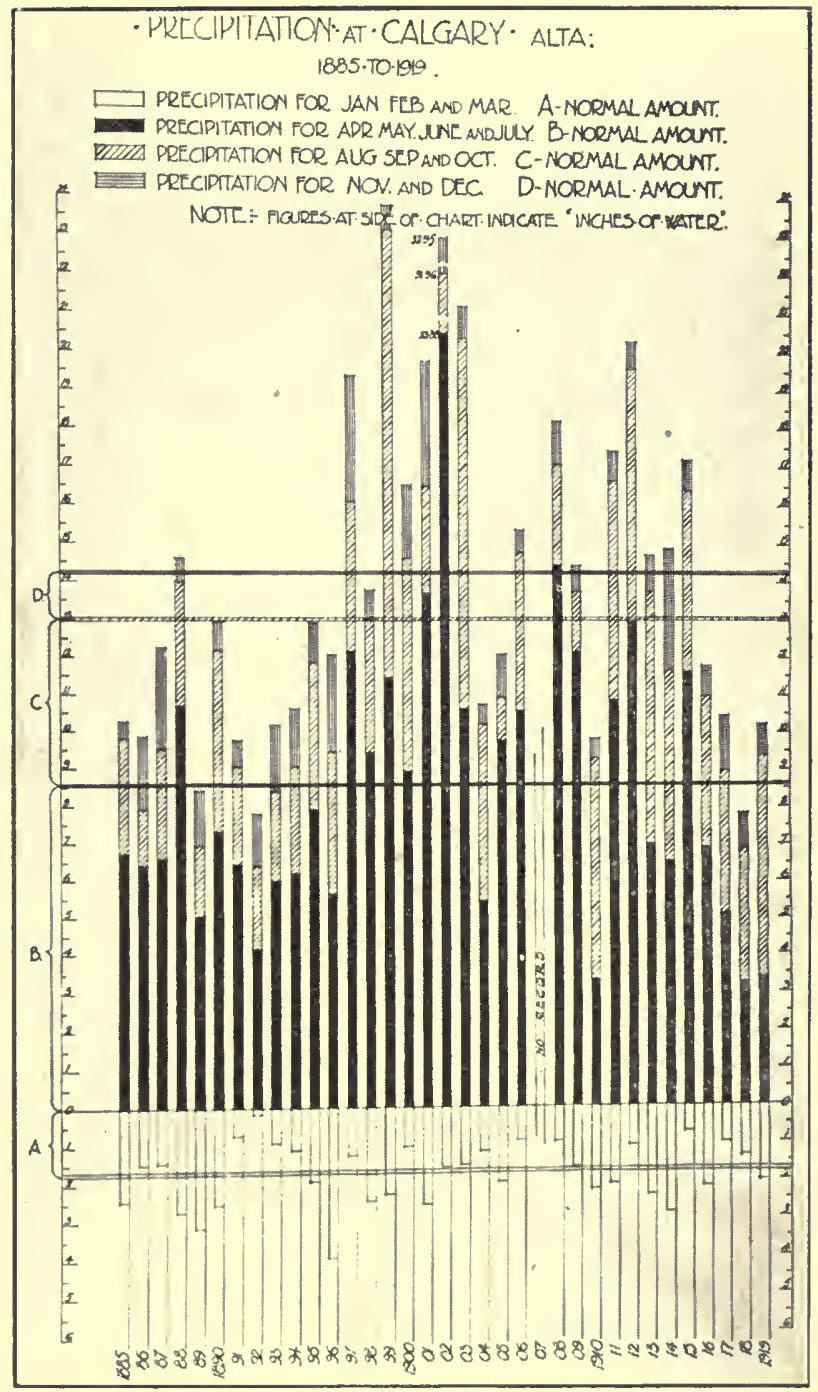

Flg. 115.-Precipitation Record-Calgary, Alberta. 


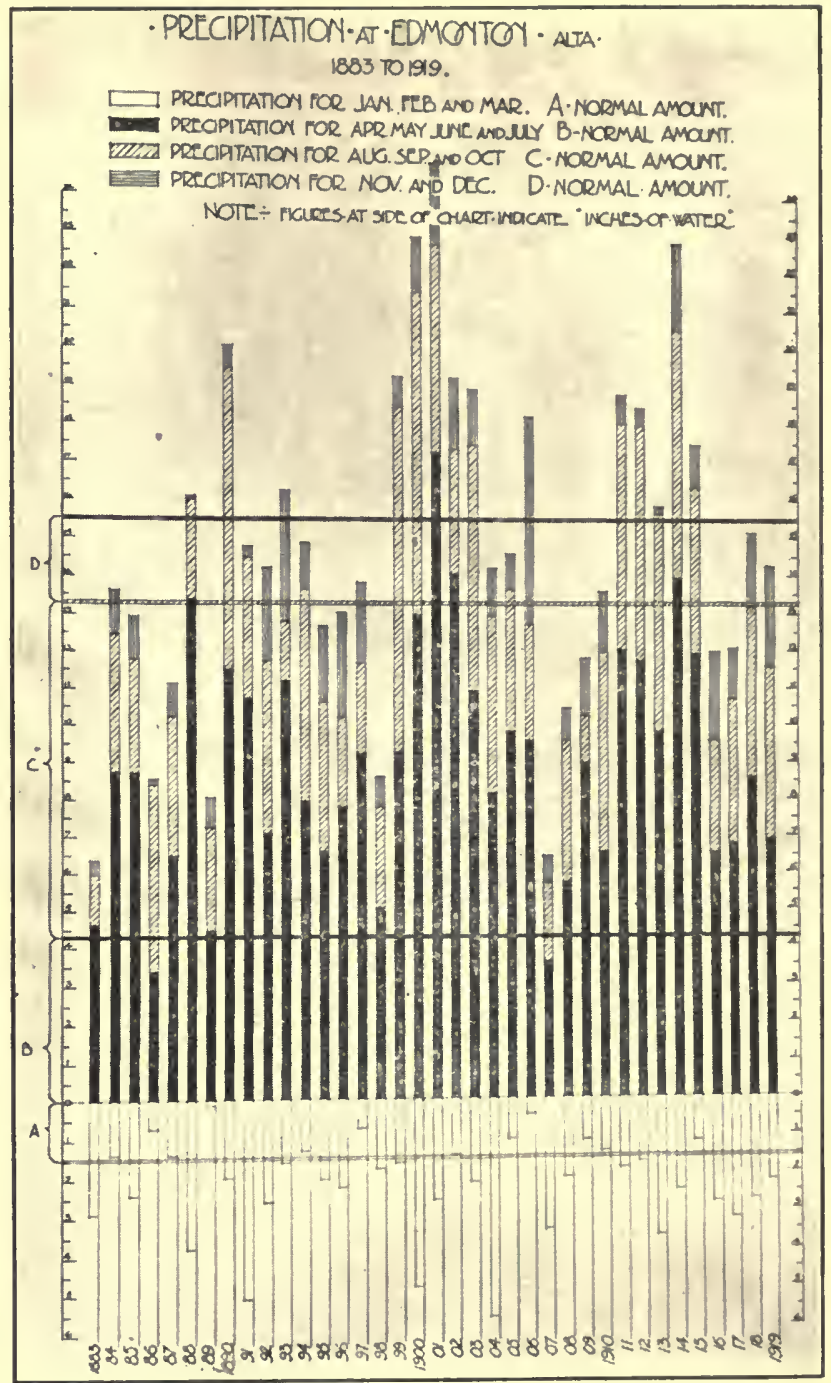

Fig. 116.-Precipitation Record-Edmonton, Alberta. 



This book is DUE on the last date stamped below

\section{NAV 24 1931 \\ JAN 281942}

Eorm I.-9-35m-8, 28 


\section{3 \\ B72d}

UNIVEKSI: I OT LALIFUKNLA

AT

LOS ANGELES 
